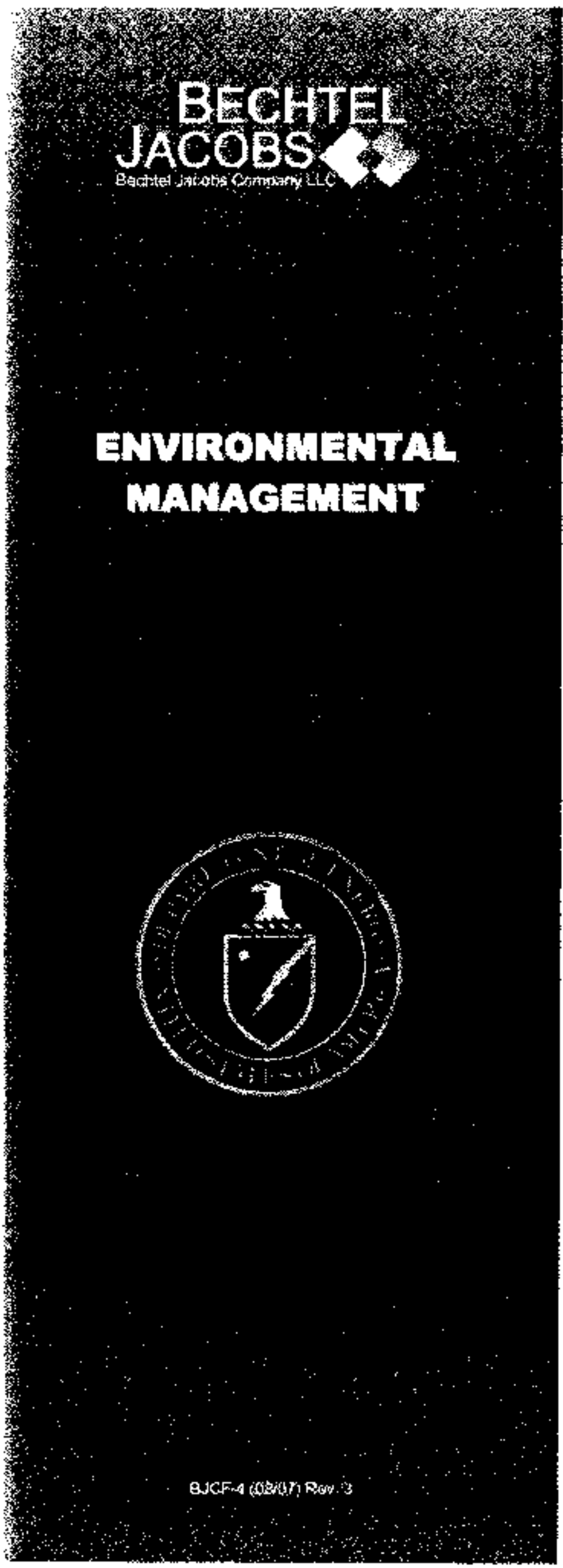

\author{
Calendar Year 2007 \\ Resource Conservation \\ and Recovery Act \\ Annual Monitoring Report \\ for the \\ U.S. Department of Energy \\ V-12 National Security Complex, \\ Oak Ridge, Tennessee \\ RCRA Post-Closure Permit Nos. \\ TNHW-113, TNHW-116, and TNHW-128
}

EPA Identification No. TN3 890090001
This docutment is approved for puhlit: release per seves by:

A. F. McBride

[3.|c F.ITP Classification $\mathbf{k}$ Intormation Control Office

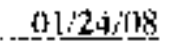

Date 


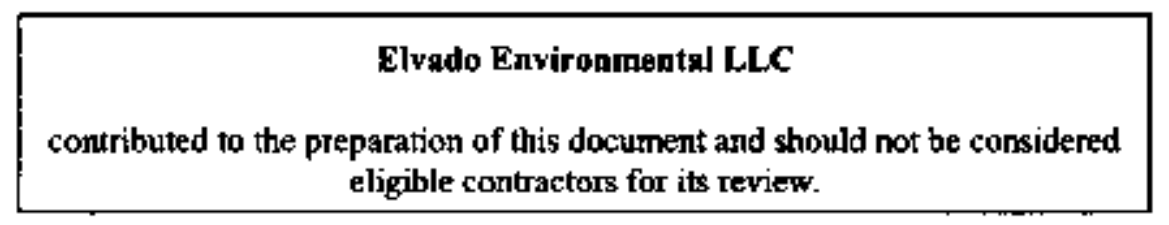




\title{
Calendar Year 2007 \\ Resource Conservation \\ and Recovery Act \\ Annual Monitoring Report \\ for the \\ U.S. Department of Energy \\ Y-12 National Security Complex, \\ Oak Ridge, Tennessee
}

RCRA Post-Closure Permits: TNHW-I 13, TNHW-1 16, and TNHW-128

EPA Identification No: TN3 890090001

Date Issued-February 2008

\author{
Prepared by \\ Elvado Environmental LLC \\ under subcontract 23900-PO-ES845
}

Prepared for the

U.S. Department of Energy

Office of Envirommental Management

\section{BECHTEL JACOBS COMPANY LLC managing the}

Environmental Management Activities at the

East Ternessee Techmology Park

Y-12 National Security Cotrplex Oak Ridge National Laboratory under contracts DE-AC05-98OR22700

for the

U.S. DEPARTMENT OF ENERGY 


\section{CONTENTS}

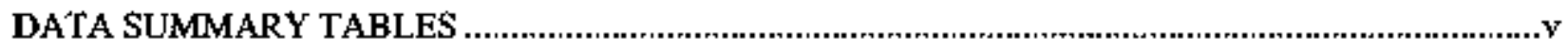

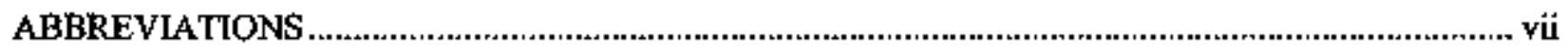

RCRA FACILITY INFORMATION

CERTIFICATTON STATEMENT

EXECUTIVE SUMMARY …..............................................................................................................

1. INTRODUCTION

2. RCRA POST-CLOSURE PERMITS AND TSD UNITS ….......................................................... 3

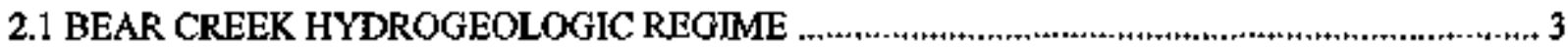

2.1 .1 S-3 Site .......................................................................................................... 3

2.1.2 Oil Landfarm ............................................................................................. 4

2.1.3 Bear Creek Burial Grounds/Walk-In Pits ........................................................... 4

2.2 UPPER EAST FORK POPLAR CREEK HYDROGEOLOGIC REGIME .................................... 4

2.2.1 Eastern S-3 Site Plume ............................................................................................................ 5

2.2.2 New Hope Pond.......................................................................................................... 5

2.3 CHESTNUT RIDGE HYDROGEOLOGIC REGIME

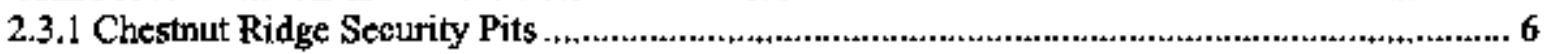

2.3.2 Chestsut Ridge Sediment Disposal Basin .......................................................................... 6

2.3.3 Kerr Hollow Quarry .............................................................................................

2.3.4 East Chestnut Ridge Waste Pile .............................................................................................. 6

3. HYDROGEOLOGIC FRAMEWORK......................................................................................

3.1 TOPOGRAPHY AND BEDROCK GEOLOGY ................................................................ 7

3.1.1 Bear Creck Valley ......................................................................................... 8

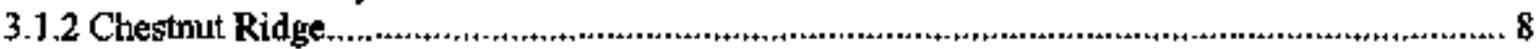

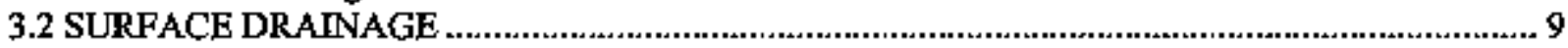

3.2.1 Bear Creek ........................................................................................................ 9

3.2.2 Upper East Fork Poplar Creek................................................................................ 10

3.2.3 Chestnut Ridge............................................................................................................. 10

3.3 GROUNDWATER SYSTEM ....................................................................................... 10

3.3.1 Bear Creek Valley.................................................................................................. 10

3.3.2 Chestnut Ridge

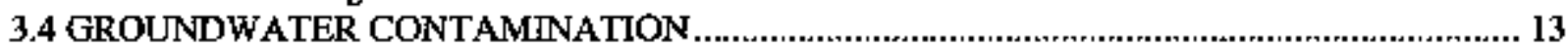

3.A.l Bear Creek Hydrogeologic Regime ................................................................................. 13

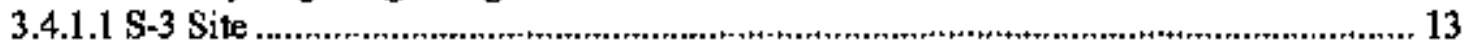

3.4.1.2 Oil Landfarm Waste Management Area _................................................................. 14

3.4.1.3 Bear Creck Burial Grounds Waste Management Ares.............................................. 16

3.4.1.4 Maytardville Limestone Exit Pathway ................................................................ 17

3.4.2 Upper East Fork Poplar Creek Hydrogeologic Regime .................................................... 18

3.4.3 Chestrut Ridge Hydrogeologic Regime .................................................................. 19

4. CY 2007 RCRA POST-CLOSURE GROUNDWATER SAMPLING AND ANALYSIS................... 21

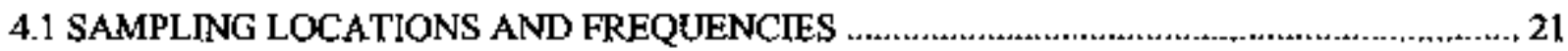

4.1.1 S-3 Site, Oil Landfarm, and Bear Creek Burial Grounds/Walk-In Pits................................. 21

4.1.2 Eastem S-3 Site Plume …................................................................................. 22 


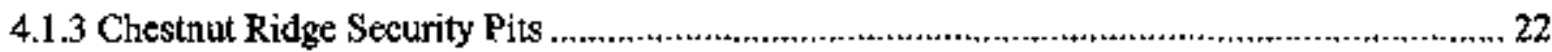

4.1.4 Chestnut Ridge Sediment Disposal Basin ................................................................... 22

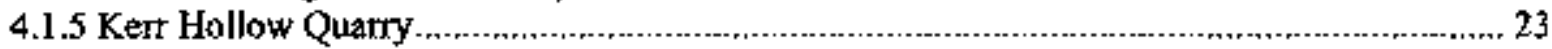

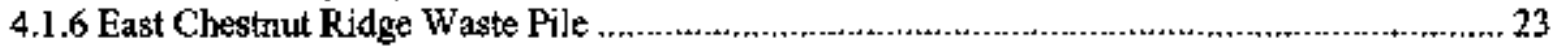

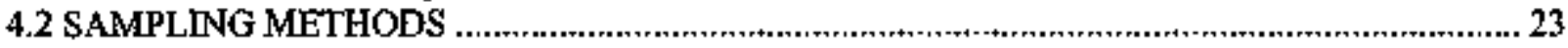

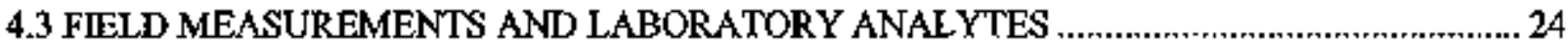

4.3.I S-3 Site, Oil Landfarm, and Bcar Creek Burial Groutds/Walk-In Pits ................................ 25

4.3.2 Ezstem S-3 Site Plume ............................................................................................ 26

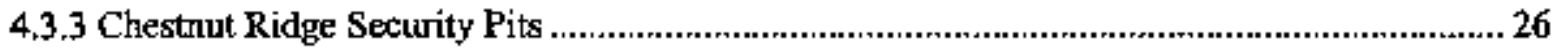

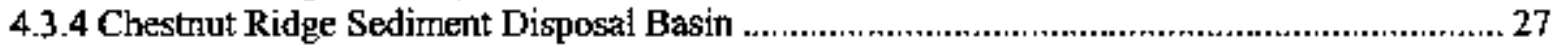

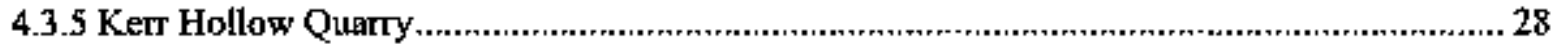

4.3.6 East Chestnut Ridge Waste Pile ....................................................................................... 28

4.4 QUALITY ASSURANCE/QUALIFY CONTROL SAMPLING ............................................ 29

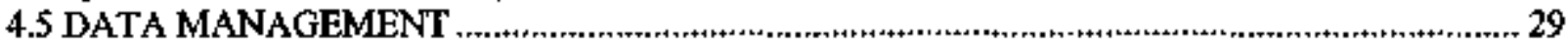

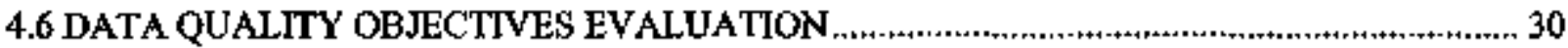

5. CY 2007 RCRA POST-CLOSURE GROUNDWATER MONITORING

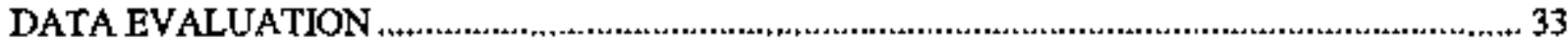

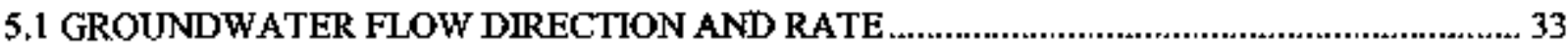

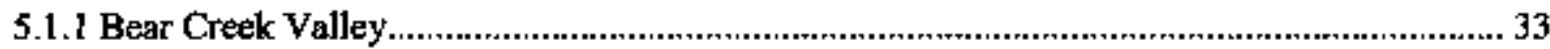

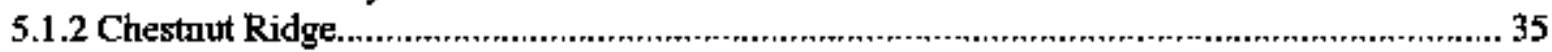

5.2 RCRA POINT-OF-COMPLIANCE MONITORING DATA

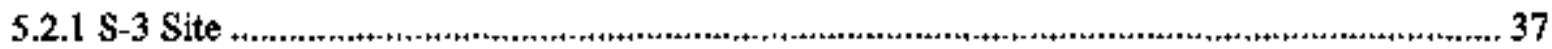

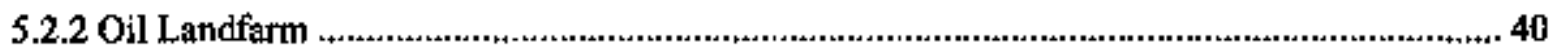

5.2.3 Bear Creek Burial Grounds'Walk-In Pits ....................................................................... 42

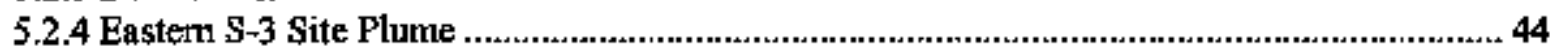

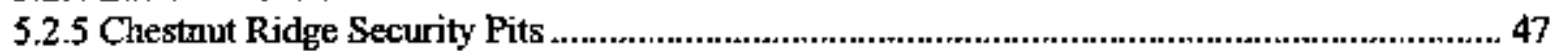

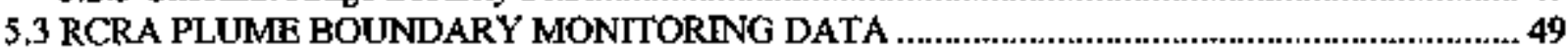

5.3.1 S-3 Site, Oil Landfarm, and Bear Creek Burial Grounds/Walk-In Pits.................................. 49

5.3.2 Eastern S-3 Site Plume ............................................................................................. 51

5.3.3 Chestnut Ridge Security Pits ............................................................................................ 52

5.4 RCRA POST-CLOSURE DETECTION MONIFORING DATA ......................................... 52

5.4.1 Chestnut Ridge Sediment Disposal Basin ....................................................................... 52

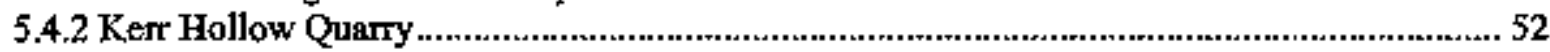

5.4.3 East Chestmut Ridge Waste File .................................................................................. 52

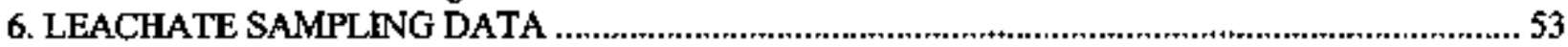

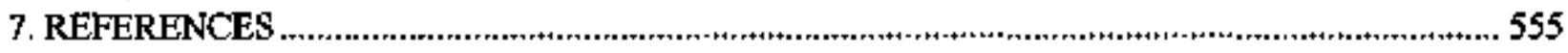

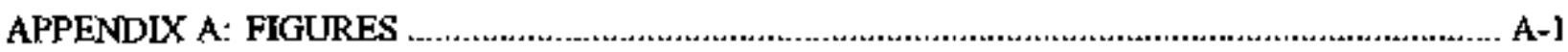

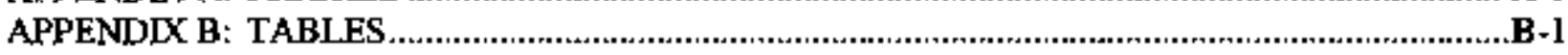

APPENDDX C: CY 2007 RCRA POST-CLOSURE GROUNDWATER MONITORING DATA FOR THE BEAR CREEK HYDROGEOLOGIC REGIME .........................................

APPENDIX D: CY 2007 RCRA POST-CLOSURE GROUNDWATER MONITORING DATA FOR THE UPPER EAST FORK POPLAR CREEK HYDROGEOLOGIC REGIME. D-1

APPENDLX E: CY 2007 RCRA POST-CLOSURE GROUNDWATER MONTTORING DATA FOR THE CHESTNUT RIDGE HYDROGEOLOGIC REGIME. E-1 


\section{DATA SUMMARY TABLES}

1 RCRA post-closure pernits and effective dates for applicable TSD units at Y-12 ...........................

$2 \mathrm{CX} 2007$ presampling groundwater elevations in wells used for RCRA post-closure corrective action monitoring at the S-3 Site, Oil Landfarm, and BCBG/WIP.

3 CY 2007 presampling groundwater ejevations in wells used for RCRA post-closure corrective action monitoring at the Easten S-3 Site Plume

4 CY 2007 presampling groundwater elevations in wells used for RCRA post-closure corrective action monitoring at the CRSP.

5 CY 2007 presampling groundwater elcrations in wells used for RCRA post-closure detection monitoring at the CRSDB.

6 CY 2007 presampling groundwater elevations in wells used for RCRA post-closure detection monitoring at KHQ .

7 CY 2007 presarmpling groundwater elevations in wells used for RCRA post-closure detection monitoring at the ECRWP

8 CY 2007 false-positive tesults for VOCs that are RCRA groundwater target compounds

9 Representative horizontal hydrautic gradients in the uppernost aquifer at the S-3 Site, Oil Landfarm, BCBG/WIP, and Eastern S-3 Site Plume, Aril 2007

10 Calculated rates of groundwater flow in the uppermost aquifer at the S-3 Site, Oil Landfarm, $\mathrm{BCBG}$ WIn, and Eastem S-3 Site Plume.

11 Representative horizontal hydraulic gradients in the uppermost aquifer at the CRSP, CRSDB, $\mathrm{KHQ}$, and ECRWP, April 2007.

12 Calculated rates of groundwater flow in the uppenmost aquifer at the CRSP, CRSDB, KHQ and ECRWP.

13 CY 2007 sampling results for the RCRA groundwater target compounds detected in S-3 Site POC well GW-276

14 CY 2007 sampling results for the RCRA groundwater target compounds detected in Oil Landfarm $P O C$ well GW-1008

I5 CY 2007 sampling tesults for the RCRA groundwater target compounds detected in BCBG/WIP POC well GW-046.

16 CY 2007 sarryling results for the RCRA groundwater target compounds detected in Eastern S-3 Site POC well GW-108 
17 CY 2007 sampling results for the RCRA groundwater target compounds detected in CRSP POC well GW-177

18 CY 2007 sampling results for the RCRA groundwater target compounds detected in RCRA plume boundary wells GW-712, GW-713, and GW-714 in the Bear Creek Regime

19 CY 2007 sampling results for the RCRA groundwater target compounds detected in RCRA plume boundary spring $\$ S-6$ in the Bear Creek Regime $50-51$

20 Summary of CY 2007 leachate sampling results for the ECRWP 


\section{ABBREVIATIONS}

AGLLSF
BCBG
BCK
BCV
Bear Creek Regime
BG
bgs
BJC
BQR
BT
BYBY
CA
CERCLA
Chestnut Ridge Regime
CRSP
CRSDB
CY
DNAPL
DOE
DQO
ECRWP
EMWMF
Energy Systetns
EPA
FY
EPd
HCDA
HWDU
KHQ
MCL
MDA
ms]
NPDES
NT
ORNL
ORR
PCP
PEMS
PCB
POC
PQL
PVC
QAVC
RCRA
REDOX
ROD

\author{
Above Grade Low-Level Storage Facility \\ Bear Creck Burial Grounds \\ Bear Creek kilometer \\ Bear Creek Valley \\ Bear Creek Hydrogeologic Regime \\ Burial Grounds \\ below ground surface \\ Bechtel Jacobs Company LLC \\ blank qualifictation result \\ buried tributary \\ Boncyard/Bumyard \\ characterization area
}

Comprehensive Environmental Response, Compensation, and Liability Act of 1980

Chestnut Ridge Hydrogeologic Regime

Chestnut Ridge Security Pits

Chestnut Ridge Sediment Disposal Basin

calendar year

denst nonaqueous phase liquid

U.S. Department of Energy

data quality objective

East Chestnut Ridge Waste Pife

Environmental Management Waste Management Facility

Lockheed Martin Energy Systems, Inc. (formerly Martin Marietta Energy Systems, Inc.)

U.S. Environmental Protection Agency

fiscal year

gallons per day

Hazardous Chemical Disposal Area

hazardous waste disposal unit

Kers Hollow Quany

maximum contaminant level

minimum detectable activity

mean sea level

National Pollutant Discharge EJimination System

north tributary (of Bear Creek)

Oak Ridge National Laboratory

Oak Ridge Reservation

post-closure permit

Project Ervironmental Measurement System

polychlorinated biphenyls

point-of-compliance

project quantitation level

polyvinyl chloride

quality assurance/quality contro]

Resource Conservation and Recovery Act of 1976

oxidation-reduction potential

record of decision 


$\begin{array}{ll}\text { RI } & \text { remedial investigation (CERCLA) } \\ \text { SAP } & \text { Sampling and Analysis Plan } \\ \text { SDWA } & \text { Safe Drinking Water Aet of } 1974 \\ \text { TDEC } & \text { Tennessee Department of Environment and Conservation } \\ \text { TDS } & \text { total dissolved solids } \\ \text { TPU } & \text { total ptepagated uncertainty } \\ \text { TSD } & \text { trettrent, storage, and disposal (unit) } \\ \text { UEFPC } & \text { Upper East Fork Poplar Creek } \\ \text { UPper East Fork Regime } & \text { Upper East Fork Poplar Creek Hydrogeologic Regime } \\ \text { VOC } & \text { volatile organic conpound } \\ \text { WIP } & \text { Walk-ln Pits } \\ \text { WMA } & \text { Waste Managernent Area } \\ \text { WRRP } & \text { Water Resources Restoration Program } \\ \text { Y-12 } & \text { Y-12 National Security Complex }\end{array}$


RCRA FACILITY INFORMATION

Facility: U.S. Department of Energy Y-12 National Security Complex (Formerly the U.S. Department of Energy Oak Ridge Y-12 Plant)

Address: P.O. Box 2001

Oak Ridge, Tennessee 37831

Identification No: TN3 890090001

Tetunessec Permit Nos. TNFW-1 13 - Upper East Fork Poplar Creek Hydrogeologic Regime

TNHW-1 16 - Bear Creek Hydrogeologic Regime

TNHW-128 - Chestnut Ridge Hydrogeologic Regime

CERTIFICATION STATEMENT

I certify under penalty of law that this document and all attachments were prepared under my direction or supervision in accordance with a system designed to assure that qualified personnel properly gather and evaluate the information submitted. Based on my inquiry of the person or persons who manage the system, or those persons directly responsible for gathering the information, the information submitted is, to the best of my knowledge and belief, true, accurate, and complete. I am aware that there are significant penalties for submitting false information, including the possibility of fine and imprisonment for knowing violations.
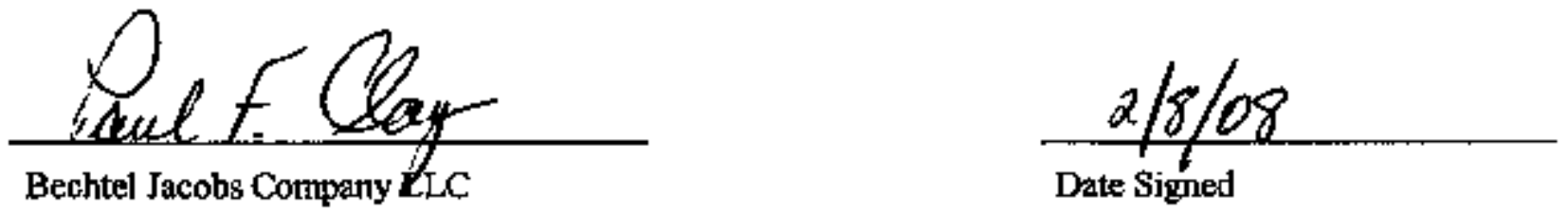

ix 


\section{EXECUTIVE SUMMARY}

This report contains groundwater qaality moniforing data obtained during calendar year (CY) 2007 af the following hazardous waste treatment, storage, and disposal (TSD) units located at the U.S. Department of Energy (DOE) Y-12 National Security Complex (hereafter referenced as Y-12) in Oak Ridge, Tennessee: the S-3 Site, Oit Landfartw, Bear Creek Burial Grounds/Walk-In Pits (BCBG/WIP), Eastern S-3 Site Phume, Chestnut Ridge Security Pits (CRSP), Chestnut Ridge Sediment Disposil Basin (CRSDB), Kerr Hollow Quarry (KHO), and East Chestnut Ridge Waste Pjle (RCRWP). The monitoring data were obtained in accordance with the appilicable Resource Conservation and Recovery Act of 1976 (RCRA) hazarcious waste post-closure permit (PCP). The Tenressee Departntent of Environment and Conservation (TDEC) - Division of Solid Waste Management issued the PCPs to define the requirements for RCRA post-slosure inspection, maintenane, atd groundwater monitoring at the specified TSD units located within the Bear Creek Hydrogeologic Regime (PCP no. TNHW-116), Upper East Fork Poplar Creek Hydrogeologic Regíme (PCP no. TNHW-113), and Chesinut Ridge Hydrogeologic Regime (PCP no. TNFW-128). Each PCP requires the submittal of an annual RCRA groundwater monitoring report containing the groundwater sampling information and antalytioal results obtained at each applicable TSD unit doring the preceding $\mathrm{CY}$, atong with an evaluation of groundwatter flow rates and diretions and the anafytical results for specified RCRA groundwater target coupounds; this report is the RCRA annulal groumdwater monitoring report for CY 2007.

The RCRA post-closure groundwater monitoriag requirements specified in the above-referenced.PCP for the Chestnut Ridge Regirre replace those defined in the pevious PCP (permit no. TNHW 088), which expired on September 18, 2005, but remained effective until the TDEC issued the new PCP in September 2006. The new PCP defines site-specific groundwater senipling and malysis requirements for the CRSDB, CRSP, and $\mathrm{KHQ}$ that difer from those established under the expired PCP, including modified surtes of laborafory analytes (RCRA groundwater target compounds) for each site and ansual rather then semiamuat sampling frequencies for the CRSDA and KHQ. The new PCP also specifies the RCRA post-closure grountwater monitoring requiremeats for the ECRWP, a closed TSD unit that was not addresked in the expired PCP.

In aceordanoe with the site-specific requirements of the respective PCP for each hydiogeologic regime, RCRA post-closure groundwater monitoring during CY 2007 involved the sampling locations and frequencies ifentified below:

- Semiannally from at least one of the site-specific point of compliance (POC) wells designated for RCRA post-elosure corrective action monitoring at the S-3 Site (GW-276), Oil Landfarm (GW-008), BCBG/WIP (GW-046), Eastern S-3 Site Plume (GW-108), and the CRSP (GW-177), and the designated upgradientbackground well for the CRSP (GW-521).

- Semiannuatly from the respestive networks of RCRA plume bondary monitoring locations in the Bear Creek Regime (wells GW-712, GW-713, aak GW-714 and spring SS-6), Upper East Fork Regime (wells GW-193, GW-605, GW-606, and GW+733), and Chestmut Ridge Regime (wells GW-301, GW-557, GW-562, GW-799, GW-801, nad GW-831, and sping SCR4.35P).

- Semiamually fron the upgradient/background well (GW -294) and anch POC well designated for RCRA post-closize detection monitoring at the ECRWP (GW-16L, GW-292, GW-293, GW-296, and GW-298). The PCP for the Chestmut Ridge Regine requires sampling only tirte of the POC 
wells during each semismmal sampling event, but samples were collected from all of the POC wells at the site during CY 2007 in order to provide additional baseline data for each well.

- Amually frotr the respective site-specifie network of upgradient/background and POC wells desigrated for RCRA post-closure detection monitoritg at the CRSDB (GW-156, GW-159, GW-731, and GW-732) and KHQ (GW+143, GW-144, GW-145, and GW-231). This reflects a change from the semianual sampling frequency required under the previous PCP for the Chestrmut Ridge Regime (permit no. TNHW-088).

As required by the general and sitespecific conditions of the applicable PCP, the groundwater samples collected during CY 2007 from the POC wells at eacir TSD unit, 4 gradientibackground wells at applicabje sites, and the RCRA plume boundary monitoring loctions in ach regine were analyzed for the RCRA groundwater target constituents designated in each PCP. All but a relative fow of the analytical results are consistent with previous RCRA post-closure groundwater monitoring data for each well and spring and meet ofter applicable data quality objectives (DQOs). Results that do not meet DOOs inciude low concentrations of volatile organic componisds (VOCs) detected in the POC wells fox the S-3 Site (acetone and methylene chloride), Eastern S-3 Site Plume (acetonc), and ECRWP (methyjene chloride); the upgradient/backgrosmd well at the ECRWP (methylene chlomide); and the RCRA plume boundary sampling locations in the Bear Creek Regime (methylene chloride). Additionally, concentrations of trace metals reported for the gloumdwater samples from the upgradient/background well at the ECRWP (ehromium, iron, and nickel) and a POC well at the site (manganose) are rejected based on DQO comperison with historical data for the well. Results that do not meet DQOs did aot adversely inspact evaluation of the RCRA post-closure gromendwator momitoring data for each applicable site.

Sitc-specific conditions of the applicable PCP collectikely reaune annual evaluation of the gromndwater flow direction and rate in the uppermost aquifer at the S-3 Site, Oil Landfam, BCBG/WT, Eastern S-3 Site Plunge, CRSP, CRSDB, KHQ, and ECRWP. Directions of groundwater flow at each site, as defined by gromindwater elevation iscpieth based on monitoring well depth-to-water messurements recorded in January 2007, are consistent with those obeerved during previous years. Based on the modified Darcy equation (and inherent assumptions), representative borizontat hydraulic gradients determined from the January 2007 groundwater elevation dath for selected monitoring wells at each TSD unit and valtes for effective porosity and hydraulic conductivity from several hydrogeologic investigations at $\mathrm{Y}-12$, calculated rates of groundwater flow in the uppermost aquifer at each site range over several orders of magnitude. The lowest flow rates $(0.0002 \mathrm{ft}$ per day) are representative of lowpermeability matrix intervals in the predominately stale bedrock urderlying the S-3 Site, Oil Landfarm, BCBG/WIP, and Eastern S-3 Site Plume, and the highest flow rates ( 1000 ft per day) are representative of the most permeable karst features in the carbonate bedrock beneath the CRSP, CRSDB, and ECRWP.

Quantitative trend analysis of the RCRA post-closure cortective action groind water monitoring results for selected RCRA groundwater torget constitzents detected in the POC wells at the S-3 Site, Oil Landfarm, BCBC/WTP, Eastern S-3 Site Plume, and the CRSP during CY 2007 was performed as required by site-specific conditions of the PCPs for the Bear Creek Regime, Upper East Fork Regime, and Chestnut Ridge Regime. The tread arnalyses were based on time-series plots of artalytical results obtained since January 1998 (which cuincides with the progranmatic change in the groundwater sanuling method), with least-squares linear regression used to determine the relative direction (upward or downward) of esch trend. Non-detected results were excluded from the trend analyses, as were results that do not meet applicable DQOs. Decreasing or indetenminate (not increasing or decreasing) concentration trends are indicated by the time-series plots of the data for selected RCRA groundwater target consituents detected in the POC wells at the S-3 Site, Oil Landfardt, BCBG/WIP, end CRSP, nond the respective tread lines deternined from linear regressicr of the data. These indings are consistent with 
conceptuad contaninant transport models developed for the S-3 Site, Oil Landifarm, BCBG/WIP, and . Eastern S-3 Site Pltane and are expectod in xesponse to the closire and subsequent ingtallation of the lowpermeability cap at each TSD unit. However, the time-series plot of technetsum-99 (Tc-99) results for Eastem S-3 Site Plume POC wefl GW-108 shows an insreasing long-term concentration trend, although the CY 2007 RCRA sampling results suggest a decrease from the Tc-99 leveis evident through Jilly 2006. It is unclear why the To-99 levels increased over the long term, especially in light of the decreasing concentrations of other contamingnts (e.g. nitrate) in the shailow groundwater from this well.

Site-zpecific conditions of the PCPs for the Bear Creek Regime, Upper East Fork Regime, and Chesinut Ridge Regime collectively require the RCRA post-closure corrective action monitoring data for the designated RCRA plume boundary monitoring locations in each regime to be evaluated annually for cvidence of contaminant transport/migration from the S-3 Site, Oil Landfarn, BCBG/WIP, Eastern \$-3 Site Phume, and CRSP. Evaluation of the respective CY 2007 sampling results indicates that each RCRA plume boundary moritoring location in the Bear Crek Regime and Chestrut Ridge Regime continue to yield uncontamingted groundwater samples and the RCRA plume boundary wells in the Upper Fast Fock Reginte yield groundwater samples that do not contain Tc-99, the "signature" conponent of the Easten S-3 Site Plume.

The CY 2007 results for RCRA post-elosure detection monitoring at the CRSDB, KHQ, and ECRWP were evaluated in acordance with the procedures described in corresponting site-specific attachments to the PCP for the Chestnut Ridge Regine. Required statistioal analyses of applicable data were completed within 90 days of the corresponding groundwater sanpling etent at each site, as recuired by the PCP for the Chestnat Ridge Regine. The groundwate sampling results for the wells at each site and the applicable statistical analyses do not indicate a release of contaminants to the uppermast acuifer at the any of these TSD units.

The PCP for the Cbestnut Ridge Regime requires the sampling and analysis of leachate from the ECRWP, with the analytieal results used to evaluate whether any constituents need to be added to the list of RCRA gropadwater target compourzds bpecified for the site. Evaluation of the CY 2007 leachate sampling rexults indicates that mo chenges to the list of RCRA gromdwater target compounds is warranted at this time, aside from oorrecting the typographical errot that identifies "chloromethane" as a target sompound instead of "chlortothone" (chloromethane thas not been detected in any of the leachate samples collexted to date, whereas ctsorothene was detected in several of the leachate ganiptes, including both samples collected during CY 2007). 


\section{INTRODUCTION}

This report contains groundwater quality monitoring data obtained during calendar year (CY) 2007 at several closed hazardous waste treatment, storgge, and disposal (TSD) units located at the U.S. Department of Energy (DOE) Y-12 National Security Complex (hereafter referenced as Y-12) in Oak Ridge, Tennessee (Appendix A, Fig. 1; directions are in reference to the Y-12 grid). The groundwater quality montoring data were obtained in accordance with the Resource Conservation and Recovery Act of 1976 (RCRA) hazardous waste post-closure permits (PCPs) issued by the Tennessee Department of Environment and Conservation (TDEC) - Division of Solid Waste Management. These PCPs define the requirements for RCRA post-closure inspection, maintenance, and monitoring of the specified TSD units, identified below in Table 1, located within the Bear Creek Hydrogeologic Regime (Bear Creek Regime), Upper East Fork Poplar Creek Hydrogeologic Regime (Upper East Fork Regime), and Chestnut Ridge Hydrogeologic Regime (Chestnut Ridge Regime).

Table 1. RCRA post-elosure pernits and effective dates for applicable TSD undts at Y-12

\begin{tabular}{|c|c|c|}
\hline $\begin{array}{c}\text { PCP Number/ } \\
\text { Hydrogeoloric Reginie }\end{array}$ & $\begin{array}{l}\text { Effective } \\
\text { Date }\end{array}$ & TSD Units \\
\hline TNHW-1 13 Jpper East Fork Regime & $09 / 23 / 2003$ & $\begin{array}{l}\text { Eastern S-3 Site Pluroe } \\
\text { New Hope Pond }\end{array}$ \\
\hline TNHW-1 16 Bear Creek Regine & $12 / 10 / 2003$ & $\begin{array}{l}\text { S-3 Site } \\
\text { Oil Lathdfarm } \\
\text { Bear Creek Burial Grownds (BCBG)Walk-In Pits (WTP) }\end{array}$ \\
\hline TNHW-1 $\overline{28}$ Chestmut Ridge Regime & $09 / 29 / 2006$ & $\begin{array}{l}\text { Chestmut Ridge Security Pits (CRSP) } \\
\text { Chestmut Ridge Sediment Disposal Basin (CRSDB) } \\
\text { Kenr Hollow Quarry (KHQ) } \\
\text { East Chestrut Ridge Waste Pile (ECRWP) }\end{array}$ \\
\hline
\end{tabular}

Site-specific requirements for RCRA post-closure groundwater monitoring at each of the above-listed TSD units, as defined in the associated PCP, are summarized in Appendix B, Table 1 (Bear Creek Regime), Table 2 (Upper East Fork Regime), and Table 3 (Chestnut Ridge Regime) and indexed to the corresponding sections of this report.

The RCRA post-closure groundwater monitoring requirements specified in the above-referenced PCP for the Chestrut Ridge Regime replace those defined in the previous PCP (permit no. TNHW-088), which expired on September 18, 2005 but remained effective until the TEEC issued the new PCP in September 2006. The new PCP defines site-specific groundwater sampling and analysis requirements for the CRSDB, CRSP, and KHQ that differ from those established under the expired $\mathrm{PCP}$, including modified suites of laboratory analytes (RCRA groundwater target compounds) for each site and annual rather than semiannual sampling frequencies for the $\mathrm{CRSDB}$ and $\mathrm{KHQ}$. The new $\mathrm{PCP}$ also specifies the RCRA post-closure groundwater monitoring requirements for the ECRWP, a closed TSD unit that was not addressed in the expired PCP.

The RCRA post-closure groundwater monitoring results contained in this report include the sampling and analysis data from the first 180 -day reporting period for CY 2007 , which were submitted previously to the TDEC before the September 1 reporting deadline specified in each respective PCP (Bechtel Jacobs Company LLC [BJC] 2007a). In addition, this report eontains the groundwater sampling and analysis results from the second 180-day reporting period for CY 2007, which must be submitted to the TDEC before the March 1 reporting deadine specified in each respective PCP. Also included in this report are 
the CY 2007 leachate sampling data obtained for the ECRWP as required by the PCP for the Chestnut Ridge Regime (Appendix B. Table 3).

Section 2 of this report includes brief descriptions of the TSD units in each hydrogeologic regime that are addressed in the corresponding PCP. Section 3 provides an overview of the hydrogeologic framework in each hydrogeologic regime, including short descriptions of the topography and bedrock geology, sufface drainage, the uppermost aquifer at each TSD unit, and the overall extent of groundwater contamination in each regime. Section 4 presents a summary of the groundwater sampling and analysis activities performed for the purposes of RCRA post-closure groundwater monitoning during CY 2007. Results of the groundwater monitoring data evaluations required by the respective $\mathrm{PCP}$ for each hydrogeologic regime are in Sect. 5. An evaluation of the leachate sampling tesults for the ECRWP is in Sect. 6 and the documents cited for more detailed operational, regulatory, and technical information are listed in Sect. 7 .

Illustrations (maps and trend graphs) and data tables seferenced in this report are in Appendjx $A$ and Appendix B, respectively. The RCRA post-closure groundwater monitoring regults obtained during CY 2007 are tabulated in Appendix C (Bear Creek Regime), Appendix D (Upper East Fork Regime), and Appendix $\mathrm{E}$ (Chestnut Ridge Regime). 


\section{RCRA POST-CLOSURE PERMITS AND TSD UNITS}

The following scctions provide brief descriptions of the hydrogeologic regimes at Y-12 and the RCRA TSD units that are addressed in the corresponding PCP for the Bear Creek Regime, Upper East Fork Regime, and Chestnut Ridge Regime.

\subsection{BEAR CREEK HYDROGEOLOGIC REGIME}

The PCP for the Bear Creek Regime defines the RCRA requirements for post-closure inspection, maintenance, and groundwater monitoring at the $\$-3$ Site (formerly the S-3 Ponds), the Oif Landfarm hazardaus waste disposal unit (HWDU), and the BCBG/WIP. The Bear Creek Regime is bound to the north by Pine Ridge and to the south by Chestrut Ridge and encompasses the portion of Bear Creek Valley (BCV) between a low topographic and hydrologic divide located near the westem end of Y-12 and the western boundary of the Bear Creek watershed (Appendix A, Fig. 2).

In addition to the S-3 Site, Oil Landfarm, and BCBG/WIP, the Bear Creek Regime encompasses numerous other hazardous and nonhazardous waste management facilities (Appendix B, Table 4). With the exception of two operating facilities, the Environmental Management Waste Management Facility (EMWMF) and the Above Grade Low-Level Storage Facility (AGLLSF), all these facilities are closed and cumrently regutated under the Comprehensive Environmental Response, Compensation, and Liability Act (CERCLA) of 1980. The EMWMF, a hazardous and mixod-waste landfill that began operating in June 2002, is regulated under CERCLA, with RCRA as an applicable, or relevant and appropriate requirement. The AGLLSF is not regulated under CERCLA or RCRA. All of the closed waste management facilities in the Bear Creek Regime, including the S-3 Site, Oil Landfarm, and BCBG/WIP, have been inactive since the late 1980s and most of these sites have undergone some level of engineered closure (e.g., installation of multi-layer, low-permeability caps).

\subsubsection{S-3 Site}

The S-3 Site is located near the headwaters of Bear Creek at the western end of Y-12 (Appendix A, Fig. 2), just west of the groundwater and surface water flow divide between the Bear Creek Regime and the Upper East Fork Regime. The former S-3 Ponds were four contiguous, unlined surface impoumdments that were used from 1951 to 1984 for the evaporation/unfiltration of several million gallons of nitric acid effluent (with depleted uranium in solution) discharged into the ponds via a pipeline (the Abandoned Nitric Acid Pipeline) connected to process buildings in the central Y-12 area (see Sect. 2.2). Also, acidic Iiquid wastes containing technetium-99 (Tc-99) that were generated at other DOE facilities periodically were transported to Y-12 for disposal at the S-3 Ponds, which is the only site at Y-12 that received Te-99 wastes. Closure of the site, initiated in 1988 , involved neutralizing and removing the liquid wastes in the ponds and stabilizing the sludge that remeined in each pond. The ponds then were filled and covered with a multi-layer, low-pemmeability cap installed to achieve RCRA final closure performance standards required for hazardous waste landfills. In 1989, an asphait-paved parking lot was constructed on top of the cap. The TDEC accepted the certification of RCRA final closure of the S-3 Site on November 15, 1990. 


\subsubsection{Oil Landfarm}

The Oil Landfarm HWDU is a component of a waste management area (WMA) in BCV that is located north of Bear Creek, approximately one mile west of Y-12 (Appendix A, Fig. 2). An estimated one million gal of waste oil and machine coolants generated at Y-12 were landfarmed at this HWDU between 1973 and 1982. [andfarming was intended to enhance the biodegtadation of these wastes via their application to nutrient-adjusted surface soils during the dry months of the year (April through Oetober). Final closure of the Oil Landfam HWDU involved the excavation and removal of soils contatninated with polychlorinated biphenyls (PCBs) and the construction of a multi-layer, low-permeability cap (including associated cap drains and stonmwater frainage system) installed to achicve RCRA final closure performance standards required for hazardous waste landfills. The TDEC accepted the sertification of RCRA final closute of the Oil Landfarm HWDU on November 15, 1990.

Other components of the Oil Landfam WMA are the Boneyard/Burnyard (BY/BY), the Hazardous Chemical Disposal Area (HCDA), and Sanitary Landfill I (Appendix B, Table 4). These non-RCRA waste management facilities are confinned or suspected sources of groundwater contamination (see Sect. 3.4.1.2) and currently are regulated under CERCLA.

\subsubsection{Bear Creek Burial Grounds/Walk-In Pits}

The BCBG/WIP are components of a WMA located in BCV approximately two miles west of Y-12 that encompasses several closed waste disposal sites designated as Burial Grounds (BG)-A North, BG-A South, BG-B, BG-C East, BG-C West, BG-D, BG-E, and BG-J; the WIP; the Uranium Vaults; and the Oil Retention Ponds (No. 1 and No. 2), which were constructed to collect oils seeping from disposal trenches in BG-A South and BG-A North, respectively (Appendix A, Fig. 2). Of these, only BG-A North, BG-A South, BG-C West, and the WIP are RCRA HWDUs; the remaining sites are regulated only under CERCLA (Appendix B, Table 4). The RCRA and non-RCRA waste disposal sites each consist of a seties of shallow (i.e., $<25 \mathrm{ft}$ below ground surface [bgs]) trenches. These trenches received a diverse mixture of solid wastes (1955 to 1993) and liquid wastes (1959 to 1979) generated at Y-12, including unknown volumes of borax (hydrated sodium borate) waste water, all or most of which may have contained varying amounts of radiological contamination.

Final RCRA closure of BG-A North, BG-A South, and BC-C West involved the constnuction of multilayer, low-permeability caps (including associated cap drains and stormwater drainage systems) installed to achieve RCRA final closure performance standards required for hazardous waste landfils. The TDEC accepted the certification of RCRA frnal closure of these sites on December 15, 1989 (BG-A North and South) and May 17, 1993 (BG-C West).

The WiP and BG-B were closed jointly in 1994 and covered with an engincered concrete revetment mat cap, a gas venting system, and a stormwater drainage system. The TDEC accepted the certification of RCRA final closure of the WIP and BC-B on November $15,1990$.

\subsection{UPPER EAST FORK POPLAR CREEK HYDROGEOLOGIC REGIME}

The Upper East Fork Regime encompasses the bulk of the Y-12 process and support structures in BCV and, for the purposes of this report, is divided into: (1) the western Y-12 area, defined as the portion of the regime west of Y-12 grid coordinate easting 55,000 ; (2) the central $Y-12$ area, defined as the part of the regime between Y-12 grid coordinate eastings 55,000 and 62,000 ; and (3) the eastem Y-12 area, defined 
as the portion of the regime east of $\mathrm{Y}-12$ grid coordinate easting 62,000 (Appendix A, Fig. 3). The PCP for the Ujper East Fork Regime defines the RCRA post-closure inspection, maintenance, and monitoring requirements applicable to the Eastern S-3 Site Plume and New Hope Pond.

\subsubsection{Eastern S-3 Site Plame}

The Eastem S-3 Site Plume is not a TSD unit as defined in the RCRA regulations, but instead is the portion of the subsurface contaminant plume that originates from the S-3 Site (see Sect. 2.1.1) and extends eastward into the westem and central Y-12 areas (see Sect 3.4.2). During operation of the site, a localized mound in the water table created by the infiltrating wastewater facilitated the subsurface transport of morganic, organic, and radiological contaminants into areas that are east of the topographic and hydrologic divide separating the Upper East Fork Regime and the Bear Creek Regime. These contaminants intermingled in the groundwater with inorganic, organtic, and radiological contarninants originating from other sources in the west and central Y-12 areas (Appendix B, Table 5).

\subsubsection{New Hope Pond}

New Hope Pond is a cloged former surface impoundment located at the eastem end of Y-12, south of Lake Reality (Appendix A, Fig. 3). Constructed in 1963, New Hope Pond served to regulate the flow and quality of surface water in Upper East Fork Poplar Creek (UEFPC) until 1988, when it was closed in accordatnce with a TDEC-approved RCRA closure plan and replaced by Lake Reality. Sediments containing PCBs, mercury, and uranium were periodically removed from New Hope Pond, but festing indicated that the sediments did not exhibit any characteristic of a hazardous waste. Approximately $25,000 \mathrm{yd}^{3}$ of sediment remained in New Hope Pond when it was closed. Closure of the site involved stabilizing the remaining sediments with coarse aggregate and covering the pond with a multi-jayer, lowpermeability cap installed to achieve RCRA final closure petformance standards required for hazardous waste landfils. The TDEC accepted the certification of RCRA final closure of New Hope Pond on December 15, 1990.

New Hope Pond is not a source of groundwater contamination, and the PCP for the Upper East Fork Regime only defines the RCRA post-closure inspection and maintenance requirements for this site. Under the terms of the PCP, requirements for groundwater monitoring at New Hope Pond, if any, are deferred to the risk-based monitoring requirements to be defined in the applicable CERCLA record of decision (ROD).

\subsection{CHESTNUT RIDGE HYDROGEOLOGIC REGIME}

The PCP for the Chestnut Ridge Regime defines the requirements for RCRA post-closure inspection, maintenance, and groundwater monitoring at the CRSDB, CRSP, ECRWP, and KHQ, each of which had been granted RCRA interim status by the TDEC. The RCRA interim status periods for the CRSDB, CRSP, and KHQ which ended on the site-specific date that the expired PCP for the regime (see Sect. 1) became effective for the CRSDB (September 18, 1995), CRSP (March 8, 1996), and KHQ (June 11, 1996). The RCRA interim status for the ECRWP ended on the effective date of the new PCP for the Chestrut Ridge Regime (September 29, 2006).

In addition to the RCRA requirements spectified in the PCP for the Chestnut Ridge Regime, the CRSDB, CRSP, ECRWP, and KHQ also are regulated under CERCLA. However, post-closure care and/or 
groundwater monitoring requitements under CERCLA have not been defined for the CRSDB, CRSP, or ECRWP (DOE 199Sa). Also, the final CERCLA ROD for KHQ, which was approved by the U.S. Environmental Protection Agency (EPA) in August 1995, defers groundwater monitoring requirements to the PCP for the Chestnut Ridge Regime (DOE 1995b).

Other non-RCRA waste management facilities are located within the Chestnut Ridge Regime, including both operating and closed non-hazadous solid waste landfills and a couple of CERCLA-regulated facilities (Appendix B, Table 6).

\subsubsection{Chestnut Ridge Security Píts}

The CRSP are located on the crest of Chestnut Ridge directly south of Y-12 (Appendix A, Fig. 4). This site encompasses two contiguous areas, each of which contains a series of unlined, east-west oriented waste disposal trenches that are about 8 to $10 \mathrm{ft}$ wide, 10 to $18 \mathrm{ft}$ deep, and 700 to $800 \mathrm{ft}$ long. Beginning in 1973, the disposal trenches at the site received a varjety of hazardous waste until December 1984 and nonhazardous wastes until the site was closed in November 1988. Closure of the site was completed in 1989 and involved installation of a multi-layer, low-permeability cap (including associated cap drains and stormwater drainage system) designed to achieve RCRA final closure performance standards required for hazardous waste landfills. The TDEC accepted the certification of RCRA final closure of the CRSP on Decentiber 15, 1989.

\subsubsection{Chestuut Ridge Sedlment Disposal Bastn}

The CRSDB is located on the crest of Chestnut Ridge about $4300 \mathrm{ft}$ east-Southeast of the CRSP (Appendix A, Fig. 4). This site was used between 1973 and 1987 for the disposal of contaminated soils and sediments removed from various areas within Y-12. Closure of the site was completed in 1989 and involved installation of a mulb-laycr, low-permeability cap (including associated cap drains and stormwater drainage system) designed to achieve RCRA final closure performance standards required for hazardous waste landfills. The TDEC accepted the certification of RCRA final closure of the CRSDB on Decetnber 15, 1989.

\subsubsection{Kerr Hollew Quarry}

Located on the southem flank of Chestnut Ridge about $3000 \mathrm{ft}$ directly south of the CRSDB (Appendix A, Fig. 4), KHQ was a source of stone construction material until it filled with water and was abandoned in the late 1940 s. From the early 1950 s until November 1988 , the quarry was used for the disposal of reactive materials from Y-12 and the Oak Ridge National Laboratory (ORNL). Wastes were removed from the quarry between mid-1990 and late 1993 to obtain certified clean-closure status from the TDEC, but the site was funally closed with some wastes remaining in place. The TDEC accepted the certification of RCRA final closure of KHQ on February 22, 1989.

\subsubsection{East Chestngt Ridge Waste Pile}

Located on the crest of Chestnut Ridge southwest of the eastem end of Y-12 and approximately $1500 \mathrm{ft}$ west of the CRSDB (Appendix A, Fig. 4), the ECRWP fonns a vegetated mound at the intersection of 
South Patrol Road and East Patrol Road, with grass-covered drainage conveyances on the south, east, and west sides of the site that converge in a stom sewer north of the site.

The ECRWP was constructed in 1986-87 by excavating into the top and northem flank of Chestnut Ridge and installing an impermeable synthetic liner on the bottom and side walls of the excavation. Constructed with a maximum design capacity of $5000 \mathrm{yd}^{3}$, the ECRWP presently contains apptoximately $3800 \mathrm{yd}^{3}$ of wastes (primarily contaminated soil generated from environmental restoration activities at Y-12) capped by $1.0-1.5$ tt of compacted clay that was covered with top soil and seeded with grass. Plastic sheeting was placed over the site (and weighted down with tires) in August 1990. Large sections of the sheeting deteriorated and, in 1999, the ECRWP was covered with a more durable, scrim-reinforced, 45-mi] polypropylene liner with welded scams.

As part of the RCRA final closure of the ECRWP, the above-referenced plastic sheeting and polypropylene liner were removed and replaced with a multi-layer low-permeability cap consisting of (from bottom to top): a minimum of 12 in. of re-compacted clay fill overlain by a geosynthetic clay liner, a textured 40-mil polyethylene geomembrane, and a composite drainage layer and topped with 12 in. soil frost protection layer and 6 in. vegetative soil cover. The TDEC accepted the certification of RCRA final closure of the ECRWP on January 5, 2006.

The bottom and side walls of the ECRWP are sloped to direct rafnwater infiltration (ieachate) into the northeast quadrant of the site, where a subsurface drainpipe conveys the leachate into a concrete sump with an approximate capacity of 540 gal. Whenever a sufficient volume of leachate has accumulated in the sump (typically when the sump is judged to be approximately $75 \%$ full), the contents of the sump are pumped into a portable container and transported to the designated treatment/disposal facility. The PCP for the Chestnut Ridge Regime defines the requirements for the management (including periodic sampling and analysis) of leachate from the ECRWP (see Sect. 6).

\section{HYDROGEOLOGIC FRAMEWORK}

The following overview of the hydrogcologic framework in the Bear Creek Regime, Upper East Fork Regime, and Chestnut Ridge Regime provides the context for the RCRA post-closure groundwater monitoring programs performed at the applicable TSD units addressed by the respective PCP for each regime. Included are brief discussions of the topography and betrock geology (Sect. 3.1), surface water drainage (Sect. 3.2), groundwater flow system (Sect. 3.3), and the extent of groundwater contamination (Sect. 3.4).

\subsection{TOPOGRAPHY AND BEDROCK GEOLOGY}

Y-12 is located within the Valley and Ridge Physiographic Province, which is gencrally characterized by extensively folded and thrust-faulted bedrock that forms an imbricate scries of northeast-southwest oriented valleys, often tuderiain by shale, and steep-sided ridges formed by more resistant carbonates and sandstones. The following overview of local topography and bedrock geology reflects the fact that the Bear Creek and Upper East Fork regines share a cormmon hydrogeologic system in BCV that has distinctively different hydrologic characteristics than evident in the Chestnut Ridge Regime. 


\subsubsection{Bear Creek Valley}

As noted previously, the Bear Creek Regime encompasses a section of BCV west of $\mathrm{Y}-12$ that historically has been used for waste management purposes (Appendix A, Fig. 5), wheteas the Upper East Fork Regime encompasses the section of BCV that contains the bulk of the historical and current operations and process facilities at Y-12 (Appendix A, Fig. 6). Bear Creek Valley is bound to the north by Pine Ridge and to the south by Chestrut Ridge, and the valley floor slopes gently to the east and west of a low topographic divide located near the west end of Y-12. Surface elevations range from $900 \mathrm{ft}$ above mean sea level (msl) along the floor of BCV to about $1200 \mathrm{ft}$ above msl along the crests of Pine Ridge and Chestrut Ridge.

Up to $50 \mathrm{ft}$ of several unconsolidated materials, including man-made fill, alluvium, colluvium, finegrained residuum from the weathering of the bedrock, and saprolite (highly weathered bedrock) overlie the bedrock formations that form BCV. Also, much of BCV within the Upper East Fork Regime contains extensive cut-and-fill areas associated with the construction of the process and support facilities that comprise Y-12 (Appendix A, Fig. 3). Most of the fill material, which generally consists of a heterogencous mixture of building debris and recompacted soil/residum that contains numerous voids, was placed within the tributaries and main channel of UEFPC (Lockheed Martin Energy Systems. Inc. [Energy Systems] 1995a).

Bedrock in BCV consists of the following shale and limestone formations of the Conasauga Group (listed in order fom oldest to youngest): Pumpkin Valley Shale, Rutledge Limestone, Rogersvilie Shale, Maryville Limestone, Nolichucky Shale, and Maynardville Limestone (Appendix A, Figs. 5 and 6). The Maynardville Limestone subcrops along the axis of BCV at the base of the steep northern (scarp) flank of Chestnut Ridge, with the remaining formations subcropping progressively to the north toward Pine Ridge. The strike (trend) and dip (inclination) of bedding is generally $N 55^{\circ} \mathrm{E}$ and $45^{\circ} \mathrm{SE}$, respectively (as referenced to true north).

\subsubsection{Chestnut Ridge}

As noted previously, the Chestnut Rjdge Regime encompasses a section of Chestrut Ridge directly south of $\mathrm{X}-12$. The northem flank of the ridge forms a steep slope rising more than 200 ft above the floor of $\mathrm{BCV}$. The ridge crest slopes east-northeast from an elevation of about 1200 ft above msl southwest of Y-12 to about 1060 $\mathrm{ft}$ above msl east of the CRSDB (Appendix A, Fig. 7). A series of ptominent hills dominates the central part of the broad southem flank of Chestnut Ridge, which is dissected by several tributary systems.

Bedrock on Chestnut Ridge is overlain by up to $100 \mathrm{ft}$ of red-brown to yellow-orange residuum composed primarily of clays and fron sesquioxides. The residuum contains semi-continuous, relict beds of fractured chert and other lithologic inhomogeneities (such as silt bodies) that provide a weakly connected network through which saturated flow can occur (Energy Systems 1992a). The residum is thin or nonexistent near karst features such as dolines (sink holes), swallets (sinking streams), and solution pan features and is thickest ( $>100 \mathrm{ft}$ ) along the crest of Chestnut Ridge (Energy Systems 1984).

Chestnut Ridge is formed by the carbonate strata of the Knox Group, which stratigraphically overlies the Conasauga Group in BCV. The Knox Group consists of about 2600 to $3300 \mathrm{ft}$ of gray to blue-gray, thinto thick-bedded cherty dolostone with intertedded limestone and is divided into the following five formations (listed from oldest to youngest): Copper Ridge Dolorrite, Chepultepec Dolomite, Longview Dolomite, Kingsport Formation, and Mascot Dolomite (Appendix A, Fig. 7). Topographic features and 
stratigraphic relationships suggest that the Copper Ridge Dolomite underlies the steep northern flank of the ridge, the Longview Dolomite forms the series of prominent hills across the middle of the southem flank of the ridge, and the Mascot Dolomite disconformably underlies the Chickamauga Group in Bethel Valley to the south (Energy Systems 1992a). As in BCV, strike and dip of bedding is generally $\mathrm{N} 55^{\circ} \mathrm{E}$ and $45^{\circ} \mathrm{SE}$, respectively (as referenced to true north).

\subsection{SURFACE DRAINAGE}

Bear Creek and UEFPC are the primary surface water drainage feanures in BCV. Bear Creek drains the sections of the valley, including all of the waste management facilities in the Bear Creek Regime, west of the topograpbic divide at the westem end of Y-12. The section of BCV to the east of the divide, which includes the bulk of the heavily industrialized areas within Y-12, is drained by UEFPC. In the Chestrut Ridge Regime, surface runoff is drained by several named and un-named tributaries that traverse generally north-south across the southern flank of the ridge.

\subsubsection{Bear Creek}

From its headwaters near the westem end of Y-12, Bear Creek flows southwest for approximately 4.5 miles, where it turns notthward to flow into East Fork Poplar Creck Monitoring locations along the main channel of Bear Creek are specified by the Bear Creek kilometer (BCK) value corresponding to the distance upstream from the confluence with East Fork Poplat Creek (e,g., BCK-09.40). Sections of the main channel are teferenced as upper Bear Creek (upstream of BCK-1 1.97), middle Bear Creek (between BCK-1 1.97 and BCK-09.40), and lower Bear Creek (downstream of BCK-09.40). For reference purposes, each northern tributary (NT) of the creek is designated with a value representing the tributary number counted downstream from the headwaters (e.g., NT-3). Major springs along the southem side of Bear Creek are numbered in ascending order from the headwaters (e.g., SS-1).

Approximately half of the amual precipitation in BCV exits via surface water flow in Bear Creek, and possibly higher proportions exit during winter and early spring (DOE 1997). Flow in the creek increases rapidly during rainfall and afterward reflects the relative contributions of overland flow, stomnflow, and groundwater discharge. Flow in the main channel and tributaries generally returns to pre-precipitation Ievels within one or two days. Major sections of upper and middle Bear Creek are seasonally dry, but flow is peremial in lower Bear Creek.

The main channcl of Bear Creck functions as a major conduit of the shallow karst network within the Maynardville Limestone. Discharge from numerous springs located along the Maynardville Limestone/Copper Ridge Dolomite boundary on the northern slope of Chestnut Ridge dominate the hydrology of the creek, especially during droughts when they provide most of the flow in the main channel. Additionally, the main channel contains alternating gaining and losing reaches. Fach gaining reach generally correlates with a major groundwater discharge area. Losing reaches in upper and nicdle Bear Creek, particularly a section of the main channel directly south of Sanitary Landfill I, play an important role in transferring contaminants from Bear Creek to the groundwater flow system (DOE 1997). 


\subsubsection{Upper East Fork Poplar Creck}

Construction of the operations and support facilities at Y-12 substantially altered UEFPC. The headwaters and several thousind feet of the main chamel in the upper reach of the creek, including all the northem tributaries of the creek in the western and central $\mathrm{Y}-12$ areas, were filled and replaced with an extensive network of underground storm drains (Appendix A, Fig. 3). For reference purposes, each buried tributary (BT) of UEFPC is designated with a value representing the tributary nutnbet counted downstream from the headwaters (e.g., BT-1).

The underground network of storm drains in the western and central Y-12 areas directs surface runoff into the exposed portion of the UEFPC channel at Outfall 200 located approximately $6000 \mathrm{ft}$ upstream of Lake Reality (Appendix A, Fig. 3). Constructed to teplace New Hope Pond, Lake Reality is a lined surface impoundment that serves to help regulate the flow and quality of surface water exiting Y-12 through UEFPC. During nomal operations, flow in UEFPC currently bypasses Lake Reality via a siphon system that has operated since December 1996; only a portion of the flow following heavy rainstorms passes through Lake Reality. Bypassing Lake Reality reduces mercury contributions to dry-weather fiow in UEFPC.

The bulk (70\%) of dry-weather flow in UEFPC, excluding flow management discussed below, is attributable to once-through noncontact cooling water, condensatc, and cooling tower blowdown, and the remaining $30 \%$ is from groundwater discharge (Energy Systems 1994a). Beginining in July 1996, untreated water from the Clinch River has been discharged near Outfall 200 to augment flow in UEFPC, which decteased from 10-15 mil gallons per day (gpd) to about 2.5 mil gpd because of reduced operations at Y-12. Flow management is needed to achieve the National Pollutant Discharge Elimination System (NPDES) minimum dajly flow requirement of $7 \mathrm{mil}$ gpd at Station 17, where UEFPC exits the DOE Oak Ridge Reservation (ORR) downstream of Lake Reality (Appendix A, Fig. 3). Flow management also allows compliance with NPDES toxicity requirements and helps lower the otherwise elevated water ternperature in UEFPC.

\subsubsection{Chestnat Ridge}

Surface streams in the Chestnut Ridge Regime include four primary drainage basins on the southern flank of Chestnut Ridge: Dunaway Branch and an urnamed tributary located east of Industrial Landfill II in the western part of the regime; the McCoy Branch drainage basin in the central part of the regine; and an unnamed draingge basin in the eastern part of the regime (Appendix A, Fig. 7). These tributaries are mainly intermittent above an elevation of $900 \mathrm{ft}$ above msl and teceive flow via sufface rumoff, stormflow discharge, and groundwate bascflow. Baseflow contributions increase downstream along the length of the streans, and spring discharge provides substantial contributions to the total flow in most of the tributaries. All of the tributaries discharge into Melton Hill Reservoir (Clinch River) south of the Chestnut Ridge Regime.

\subsection{GROUNDWATER SYSTEM}

\subsubsection{Bear Creek Valley}

There are two basic hydrogeologic units in BCV: (1) the Aquifer, consisting of the Maynardville Limestone (upper Conasauga Group) and Copper Ridge Dolomite (lower Knox Group); and (2) the 
Aquitard, conșisting of the remaining Conasauga Group formations and the underlying Rome Formation (Energy Systems 1992a). The Aquitard is the uppermost aquifer at the each of the TSD units addressed in the PCP for the Bear Creek Regime (S-3 Site, Oil Landfarm, BCBG/WIP), as well as the Eastern S-3 Site Plume in the Upper East Fork Regime. In both regimes, the Aquitard is hydraulically upgradient of the Aquifer, which functions as a hydrologic drain in BCV. Fractures provide the principal groundwater flowpaths in both units, and dissolution of carbonates in the Aquifer has enlarged fractures and created solution cavities and conduits that greatly enhance its bydraulic conductivity relative to the Aquitard. Althotigh negligible in both units, flow through the porous rock matrix plays an important role in contaminant migration because of matrix diffusion processes (Energy Systems 1992a).

Groundwater flow in the Aquitard and the Aquifer primarily occurs in directions that parallel the strike and dip of bedding, which in the Aquitard may or may not coincide with the direction of maximum hydraulic gxadient inferred from water level isopleths. Flow across bedding occurs primarily along permeable zones formed by cross-cutting fractures or fracture zones (and possibly small faults). The northen tributaries of Bear Creek are probably the surface expression of these cross-cutting structures in the bedrock. Such structures provide preferred flowpaths that channel groundwater frotn the Aquitard to the Aquifer or act as barriers to lateral flow, causing groundwater from decper intervals to upwell and discharge to the shallower flow system in each hydrogeologic unit (DOE 1997). In the Aquitard, most groundwater flow occurs in a highly permeable interval near the bedrock/resionum interface (the water table interval) and decreases substantiaily at depths more than $100 \mathrm{ft} \mathrm{bgs}$, where upward bydraulic gradients predominate (DOE 1997). In the Aquifer, most groundwater flow occurs at shallow depths (i.e., $<100 \mathrm{ft}$ bgs) in an extensively intercomnected network of solution conduits and cavities (karst network). Active groundwater circuiation occurs at greater depth than in the Aquitard and, in the Bear Creek Regine west of X-12, groundwater from the deeper flow system discharges along major gaining (influent) reaches of Bear Creek. These discharge areas are probably related to large-scale structural (e.g., cross-strike faults) or stratigraphic discontinuities in the Maynardville Limestone (DOE 1997).

The water table in the Bear Creek Regime (Appendix A, Fig. 8) and in the Upper East Fork Regime (Appendix A, Fig. 9) is a subdued replica of the ground surface in each regime, with steep gradients along the flanks of Pine Ridge and Chestnut Ridge and a gentle slope down the axis of BCV toward the west in the Bear Creek Regime and toward the east in the Upper East Fork Regime. Horizontal hydraulic gradients are typically less than 0.05 across BCV (strike-normal) in the Aquitard and are usually near 0.01 along the axis of BCV (strike-parallel) in the Aquifer (Maynardville Limestone). Static water level data for several two- and three-well clusters indicate that vertical hydraulic gradients are predominately downward in the Aquifer and upward in the Aquitard, and they often reverse in response to seasonal (or episodic) groundwater flow conditions.

Local groundwater flow patterns in both the Aquitard and Aquifer throughout much of the Upper East Fork Regime are strongly influenced by the numerous industrial, process, and support buildings and structures and the extensive network of buried utilities, sumns, storm drains, sanitary sewers, and process lines. In the western Y-12 area, for instance, operation of sumps to suppress the local water table below the basement flooss of Bldgs. 9204-4, 9201-5, and 9201-4 (Appendix A, Fig. 9) strongly influences local groundwater flow and contaminant transport patterns in both the shallow and deeper flow system in the Aquitard (DOE 1998). Similarly, in the eastern Y-12 area, groundwater flow directions at shallow depths in the Aquifer (Maynardville Limestone) are strengly influenced by the UEFPC distribution channel underdrain, which apparently functions as a highly permeable groundwater flow path and a constant head (recharge) boundary (BJC 1998). Additionally, operation of the Lake Reality Sump, which is a 6-ft diameter, 20-ft deep surm installed to reduce hydraulic pressure on the synthetic liner in Lake Reality, creates an elongated cone of depression in the Aquitard (Nolichucky Shale) oriented paralle] with strike and decreases water levels in the Aquifer (Maynardville Limestone) along the main chantxel of UEFPC. 
The sump is activated manually as required (very infrequently) to reduce pressure head and stop liner flotation. Once activated, the sump pump operates on an automatic level switch.

Complex local groundwater flow patterns in the Aquifer at the eastem end of Y-12 are indicated by the water level drawdown and recovery data obtained during aquifer pumping tests performed in July 1998, which showed: (1) rapid, large responses in wells located along strike to the east and across strike to the north of the pumping well (well GW-845); (2) more moderate responses in wells located oblique to otrike near the contact with the Nolichucky Shale to the east of the pumping well; (3) weak responses in upgradient wells in the Maynardville Limestone to the west of the pumping well; and (4) little if any response in wells located adjacent to Lake Reality and the UEFPC distribution channel underdtain to the north and northwest of the pumping well. The maximum observed radius of influence from the pumping well encompassed the entire subctop of the Maynardville Limestone in the eastem Y-12 area, with particularly strong anisotropies to the east (along strike) and north (up-dip) of the well and lowpermeability boundary effects evident along the contact with the Nolichucky Shale. Additionally, the UEFPC distribution channel underdrain, the original UEFPC mainstem, and Lake Reality apparently represent constant head (recharge) sources to the shallow groundwater and may collectively function as a hydraulic boundary to the west and northwest of New Hope Pond. The UEPPC distribution channel underdrain in particular appears to function as a separate hydraulic system that may be conuected to sufface watet flow in UEFPC (BJC 1998).

\subsubsection{Chestnut Ridge}

The principal hydrogeologic unit in the Chestrut Ridge Regime is the Knox Aquifer, which is comprised of the Knox Group and the underiying Maynardville Limestone formation of the Conasauga Group. The Knox Aquifer is the uppermost aquifer at the CRSDB, CRSP, ECRWP, and KHQ and generally consists of three vertically gradational subsystems: the stormflow zone, the vadose zone, and the groundwater zone. The subsysterns are distinguished by groundwater flux, which decreases with depth (Energy Systems 1992a).

Although detailed studies have not been performed in the Chestnut Ridge Regime, investigations in Bethel Valley and Melton Valley near ORNL, show that groundwater occurs intermittently above the water table in a shallow "stormflow zone" that extends to a depth of about $6 \mathrm{ft}$ bgs (Energy Systems 1989a). Macropores and mesopores provide the primary channels for lateral flow in the stormflow zone, which lasts only a few days or weeks after rainfall. Most groundwater within the stomflow zone is ejther lost to cvapotranspiration or recharge to the water table, and the remaining water discharges at nearby steps, springs, or streams (Energy Systems 1989a).

The vadose zone occurs between the stormflow zone and the water table, which typically occurs near the bedrock/residuum interface. The vadose zone is unsaturated except in the capillary fringe above the water table and within wetting fonts during periods of vertical percolation from the stormflow zone (Energy Systems 1989a). Most recharge through the vadose zone is episodic and oceurs along discrete permeable fractures that become saturated, although surrounding micropores remain unsaturated (Energy Systems 1992 ).

Groundwater below the vadose zone occurs within orthogonal sets of permeable, planar fractures that form water-producing zones within an essentially impermeable matrix. Dissolution of bedrock carbonates has enlarged fractures and produced an interconnected conduit-flow system characteristic of karst aquifers. Because the occurrence of solution features and the frequency, aperture, and connectivity of permeable fractures decrease with depth, the bulk hydraulic conductivity of the groundwater zone is 
vertically gradational. Most groundwater flux occurs within the transitional horizon between residuum and unweathered bedrock (water table interval); lower flux (and longer solute residence times) occurs at successively greater depths in the bedrock (Energy Systems 1992a).

The water table in the Chestnut Ridge Regime is a subdued replica of surface topography and occurs at the greatest depth ( $100 \mathrm{ft}$ bgs) along the crest of Chestnut Ridge, which is a groundwater flow divide and a recharge area. In the northem part of the regime, groundwater generally flows from west to cast, parallel to the flow divide along the ridge crest, with radial components of flow north into BCV and south toward tributary headwaters on the southen flank of the ridge (Appendix A, Fig. 10). The central part of the regine is characterized by radial flow directions from local groundwater flow divides along hilltops between tributaries. Groundwater flow directions in the southem part of the regime are generally south toward Melton Hill Reservoir. The overall directions of groundwater flow throughout the Chestnut Ridge Regime do not significantly change during seasonal groundwater flow conditions. Seasonal horizontal hydraulic gradients are highest along the steep northem flank of Chestnut Ridge (i.e., across geologic strike) and in the upper reaches of tributaries on the southern ridge flank, but are nearly flat along the southern boundary of the regime.

\subsection{GROUNDWATER CONTAMINATION}

\subsubsection{Bear Creek Hydrogeologic Regime}

There are numerous sources of groundwater contamination in the Bear Creek Regime (Appendix B, Table 4), most of which are directly underlain by the low-permeability formations that comprise the Aquitard. The principal groundwater contaminants are inorganic compounds (primarily nitrate); trace metals (notably uranium); volatile organic compounds (VOCs), including chlotinated solvents and petroleum hydrocarbons; and several radionuclides, chiefly Tc-99 and uranjum isotopes. Mobile contaminants from the various source areas are transported toward the Aquifer (Maynardville Limestone). In the Aquifer, intermingling of contarninatits from multiple source areas has produced an essentially continuous groundwater contaninant plume of varying composition that extends from the western end of Y-12 to the westem (downgradient) boundary of the BCBG WMA (Appendix A, Fig. 11). The following subsections describe the extent of contamination originating from the primary source areas in the Bear Creek Regime (the S-3 Site, the Oil Landfarm WMA, and the BCBG WMA) and the principal contaminant migration pathway (the Maynardville Limestone and Bear Creek) in the regime.

\subsubsection{S-3 Site}

Operation of the former \$-3 Ponds emplaced a large reservoir of contarnination in the Aquitard (Nolichucky Shale) containing a heterogeneous mix of inorganic, organic, and radioactive constituents. The principal groundwater contaminants are: nitrate; Tc-99 and uranium isotopes (primarily U-234 and U-238); scverai trace metals, which is the term used heresfter to differentiate metals that are typically minor constituents in groundwater (e.g., cadmium) from metals that are usually major ionic species (e.g., magnesium); and VOCs. Contaminant concentrations in the Aquitard nearest the site substantially exceed the applicable state or federal maximum contaminant level (MCL) established under the Safe Drinking Water Act (SDWA) of 1974. Also, the concentrations of most contaminants have probably achieved maximum levels and are expected to decrease as the center of mass of the plume slowly moves westward via strike-parallel groundwater flow/transport pathways in the Aquitard. Westward migration of 
contaminants in the Aquitard occurs until they encounter a cross-cutting structure that promotes upward discharge into the shallow flow system, or cross-strike flow into the Aquifer (DOE 1997).

As indicated by the distribution of nitrate, which is a highly mobile and chemically stable contaminant that delineates the maximum extent of groundwater transport and effectively traces the principal migration pathways, the S-3 Site contaminant plume in the Aquitard west of $\mathrm{Y}-12$ extends south toward the upper reach of Bear Creek and westward along strike in the water toble interval (and the deeper bedrock) toward discharge areas in NT-1 and NT-2 (Appendix A, Fig. 11). Nitrate (as N) concentrations (hereafter synonymous with "nitrate" concentrations) within the plume exceed 10,000 milligrams per liter $(\mathrm{mg} / \mathrm{L})$ in the deep bedrock directly below the S-3 Site, $1000 \mathrm{mg} / \mathrm{L}$ in the shallow groundwater near the site, and $10 \mathrm{mg} / \mathrm{L}$ near the plume boundaries.

Radiological contaminants within the S-3 Site contaminant plume include both alpha- and beta-particle emitting radionuclides, including americium-241 (Am-241), neptunium-237 (Np-237), radium, and strontium-90 ( $\mathrm{Sr}-90)$, but uranium isotopes (U-234 and U-238) and Tc-99 are the principal radiological contaminants. The highest levels of gross alpha activity within the plume exceed 1000 picoCuries per liter (pCi/L) and generally occur within the acidic groundwater nearest the S-3 Site, and the levels decrease rapidly in the more neutral $\mathrm{pH}$ groundwater encountered farther from the site. In contrast, substantially higher levels of gross beta activity $(10,000 \mathrm{pCi} / \mathrm{L})$, which is primarily from $\mathrm{T} c-99$, dominates the other radiological contaminants within the piume. Under oxidizing conditions, Tc-99 occurs as the pertechnetate anion ( $\mathrm{TcO}_{4}$ ), which is soluble and highly mobile in the subsurface (Gee et al. 1983). Based on the distribution of elevated gross beta activity indjcated by the current network of monitoring wells in $\mathrm{BCV}$, the transport of Tc-99 in the groundwater appears to be similar to that of nitrate from the $\mathrm{S}-3$ Site.

Lesser components of the S-3 Site contaminant plurne are trace metals and VOCs. Some of the trace metals (e.g., uranium) were entrained in the acidic wastes disposed at the site, and others (e.g., barium) were dissolved from the underlying saprolite and bedrock minerals. Also, the distribution of trace metals is less extensive than that of nitrate and radioactivity, but the most mobile metals within the plume (e.g., barium) have been transported beyond the acidic groundwater (pH <5) nearest the site. Acetone and tetrachloroethene (PCE) are the principal VOCs within the plume. Very high PCE concentrations in wells adjacent to the site, which exceed 5000 micrograms per liter $(\mu \mathrm{g} / \mathrm{L})$, potentially indicate the presence of PCE as dense nonaqueous phase liquid (DNAPL) in the subsurface. Nevertheless, sumrned concentrations of dissolved VOCs in the groundwater only $500 \mathrm{ft}$ downgradient of the sitc are less than $50 \mu \mathrm{g} / \mathrm{L}$.

The S-3 Site contains varying amounts of sludge produced by denitrification of the wastewater during closure of the former $\$-3$ Ponds. Sludge within the saturated zone may release Tc- 99 and uranium isotopes to the shallow groundwater flow system in the Aquitard and may be transported westward through the water table interval toward discharge points in NT-1 (DOE 1997). Additionally, matrix diffusion and advective transport jrocesses are slowly releasing contaminants (e.g., nitrate) from the deeper reservoir into the more active (shallow) Aquitard flow system.

\subsubsection{Oll Landfarm Waste Management Area}

The primary sources of groundwater contaminants in the Oil Landfarm WMA (listed in order of importance) are the BY/BY, the HCDA, the Oil Landfarn HWDU, and Sanitary Landfill I. Each site is a confimed or suspected source of VOCs in the shallow groundwater, and the BX/BY was a major source of elemental uranium and alpha activity. 
The Boneyard was used for the disposal of magnesium chips and construction debris (e.g.y concrete) in unlined shellow trenches. Filled trenches were covered with topsoil and seeded with grass. The Burnyard consisted of two unlined trenches, each about $300 \mathrm{ft}$ long by $40 \mathrm{ft}$ wide, in which various types of refuse (including pesticide containers, metal shavings, solvents, oils, and laboratory chemicals) were burned. Waste materials containing bigh concentrations of uranium were within the saturated zone during seasonally bigh groundwater levels. Results of the CERCLA remedial investigation (RI) for the Bear Creek characterization area (CA) indicated that uranium isotopes leached from the wastes move with the shallow groundwater and discharge into NT-3, which drains the site, and recharges directly into the Maynardville Eimestone (DOE 1997). Uranium isotopes from the BY/BY were the suspected source of the elevated levels ( $>1000 \mathrm{pC} / \mathrm{L}$ ) of gess alpha and gross beta activity in the shallow groundwater along NT-3, and the site was priotitized for CERCLA remedial action. Remedial action field work completed in Novernber 2001 primarily involved construction of an upgradient subsurface drain to hydraulically isolate the buried wastes at the site in order to reduce the flux of contaminants from the site and to dry the site in preparation for the excavation, disposal, and consolidation of the wastes. Approximately $64,000 \mathrm{yd}^{3}$ of waste materials with the highest concentrations of uranium that were in contact with groundwater were removed from the site by October 2002. These wastes were disposed in the EMWMF. Approximately $17,000 \mathrm{yd}^{3}$ of other waste materials that had lower levels of uranium contamination and were not in contact with groundwater also were excavated, consolidated onsite, and covered with a low-pemeability recompacted clay cap. Installation of the cap, including seeding/mulching the topsoil cover, was completed in November 2002. Additionaliy, field work to restore the NT-3 stream channel with natural meanders and gradients in order to reduce erosion of the bark and more efficiently transport water and sediment load through the BY/BY was completed in May 2003.

The HCDA was constructed on top of the Burnyard in 1975 and was used as an area for releasing compressed gas from cylinders with leaking or damaged valves and for disposal of reactive or explosive laboratory chemicals. The chemicals were handed to induce the expected reaction or explosion, and remsining líquids were discharged into a smali unlined surface impoundment. A low permeability cap was constructed over the HCDA during closure of the Oil Landfarm HWDL. In June 2002, a section of the northwestem corner of the cap was excavated and removed during the CERCLA remedial action at the BY/BY. Excavated wastes were replaced with uncontaminated soil, and the filled area was graded to drain, mulched, and seefied with grass. The HCDA is the suspected source of a dissolved VOC plume in the stallow groundwater. Primary components of the plume are trichlorothene (TCE), cis-1,2-dichlorothene (c12DCE), and PCE. Maximum concentrations of these VOCs are less than one percent of solubility, indicating that DNAPLs are probably not present in the subsurface. The HCDA is most likely the princjpal source of the plume considering the distribution of VOCs relative to the radioactivity plutne originating from the BY/BY (Appendix A, Fig. 11).

The primary groundwater contaminants at the Oil Landfarm HWDU are VOCs. The plume of VOCs in the groundwater contains two distinct suites of VOCs, one dominated by $1,1,1-t$ trichloroethane (111TCA), 1,1-dichloroethane (1 IDCA), and 1,1-dichloroethene (11DCE) near the northeastern landfarm plots, and one dominated by PCE, cl2DCE, trans-1,2-dichloroethene (tI2DCE), and TCE near the southern landfarm plots. The primary VOCs in the plume are 111TCA and PCE. Both of these parent compounds are corrponents of wastes that were landfarmed in each area, but the other VOCs in the groundwater may be present as degradrtion products of 111TCA (11DCA and 11DCE) and PCE (TCE and c12DCE). Although historical data show that summed VOC concentrations exceed $1000 \mathrm{\mu g} / \mathrm{L}$ in the northeastern part of the plume and $100 \mu \mathrm{g} / \mathrm{L}$ in the southem part of the plume, the maximum concentrations of individual plutae constituents do not indicate the presence of DNAPLs in the subsufface (DOE 1997).

Sanitary Landfill I was used between 1968 and 1980 for disposal of combustible and decomposable solid wastes from Y-12, some of which may have included toxic chenticals. Disposal trenches at the landfill 
were excavated to depths of about $20 \mathrm{ft}$ bgs and backfilled to about $15 \mathrm{ft}$ above grade. The landfill was graded and capped in 1985. This Jandfill is an unverified potential source of 11DCA, cl2DCE, and t12DCE in the shallow groundwater (Aquitard and Aquifer) downgradient to the south and west of the site (Appendix A, Fig. 11). Marinum concentrations of these VOCs are typically less than $50 \mu g / L$. In the Aquifer (Maynardville Limestone), these constituents have intermingled with VOCs (primarily TCE and c12DCE) originating from upgradient sources. Additionally, unusually high boton hevels in the groundwater at several wells immediately downgradient (west) of the site also may be attributable to contaminant migrations from Sanitary Landfill I (DOE 1997).

\subsubsection{Bear Creek Burial Grounds Waste Management Area}

Groundwater in the Aquitard underlying the BCBG WMA is extensively contaminated with VOCs at both shallow (water table) and deep (bedrock) intervals (Appendix A, Fig. 11). There are five primary source areas: BG-A (North and South), BG-C (East and West), and the WIP. Dissolved VOC plumes in the shallow groundwater at several of these source areas are probably related to widespread occurrence of DNAPLs in the subsurface. Contamination in the deeper groundwater flow system reflects density-driven, downward migration of DNAPLs (DOE 1997).

The disposal trenches comprising BG-A (North and South) received almost two million gallons of waste oils and coolants, and DNAPLs have been encoustered in monitoring wells downdip (south-southwest) of source trenches in BG-A South. Dissolved VOC plumes in the groundwater underlying both areas are dominated by PCE, TCE, and c12DCE. Other common plume constituents are 111TCA, 11DCA, and 1,2-dichlorothane (12DCA). Summed concentrations of these plume constituents exceed $100,000 \mu \mathrm{g} /$. Groundwater in the water table interval transports the plume constituents along strike toward discharge areas in NT-7. Westward, strike-parallel migration also occurs below the water table interval, as indicated by PCE results for deeper bedrock wells at BG-A South (DOE 1997).

Separate plumes of dissolved VOCs apparently occur in the shallow groundwater at BG-C East and BG-C West, each plume dominated by c12DCE with lesser amounts of vinyl chloride (VC). Concentrations of VOCs within the plume are generally less than $500 \mu \mathrm{g} / \mathrm{L}$. Groundwater containing these VOCs discharges to the NT-8 catchment on the northwestern side of BCBG WMA. Data for both source areas do not clearly indicate the presence of DNAPLs in the subsurface (DOE 1997).

Groundwater near the WTP contains a distinct plume of dissolved VOCs dominated by PCE. Concentrations exceed $2000 \mathrm{\mu g} / \mathrm{L}$, which is about $1 \%$ of the maximum PCE solubility and possibly indicates DNAPLs in the subsurface. Contanninants in the shallow groundwater flow system may not discharge extensively to surface water (DOE 1997).

Although large quantities of uranjum wastes were disposed in the BCBG WMA, few monitoring wells in the area yield radioactive groundwater samples (Appendix A, Fig. 11). However, analytical data for soil samples and surface water samples collected from Bear Creek tribularies NT-6, NT-7, and NT-8 indicate that BG-A South and BG-C East are probable sources of radioactivity (DOE 1998). Maximuth gross ajpha and gross betr activities in the samples from these tributaries ranged from about $20 \mathrm{pCi} / \mathrm{L}$ to more than $100 \mathrm{pCi} / \mathrm{L}$. The disparity with the groundwater sample data may be an artifact of the monitoring wel] network (few wells are screened within the shallowest water table interval where radioactive contamination likely occurs), but the relatively low levels of radioactivity in the groundwater also suggest that the bulk of the uranium wastes in BG-A South and BG-C East are not within the saturated zone (DOE 1997). 
Boron is the primary trace metal contaminant in the groundwater at the BCBG WMA. Elevated boron concentrations occur primarily in the shallow groundwater near BG-A South and BG-C (East and West) and probably resulted from disposal of borax wastewaters from Y-12. Boron is most likely present in the groundwater as borate $\left[\mathrm{B}(\mathrm{OH})_{3}\right]$, which is chemically stable and relatively mobile, and is transported toward discharge points in Bear Creek tributaries NT-7 and NT-8.

\subsubsection{Maynardvlle Lkmestone Exit Pathway}

In the Bear Creek Regime, the principal groundwater contaminants in the Maynardville Limestone are nitrate, VOCs, radioactivity, and trace metals. These contaminants primarily originate from the S-3 Site (nitrate, trace metals, and radionuclides), the BY/BY (uranium isotopes), the HCDA (VOCs), Sanitary Landfill I (VOCs), the BCBG WMA (VOCs and radionuclides), and the Rust Spoil Area (VOCs) or a nearby unidentified VOC source area in the Bear Creek floodplain (DOE 1997). These contaminants enter the Maynardville Limestone through direct recharge, hydrologic communication with surface water in Bear Creek, and inflow of shallow groundwater from the Aquitard. Relative contributions from the source areas and the geochemical characteristics of the contaminants have produced two primary plumes of contamination in the groundwater: one contafining nitrate and radioactivity, and another containing VOCs. These plumes occur in both the shallow karst network and the deeper fracture flowpatis and are commingled downgradient of the BY/BY and HCDA. Trace metal contaminants arc more sporadically distributed and chiefly occur close to the primary source areas.

The nitrate plume in the Maynardville Limestone essentialjy delineates the maximum extent of contaminant transport in the Bear Creek Regime and effectively traces the primary migration pathways (Appendix A, Fig. 11). The plume is continuous in the deeper bedrock from south of the S-3 Site for about $10,000 \mathrm{ft}$ along strike to the west, wheress attenuation from more active recharge and groundwater flux has reduced nitrate levels and produced a more discontinuous plume in the shallow karst network (DOE 1997). Nitrate concentrations within the plume exceed $500 \mathrm{mg} / \mathrm{L}$ south of the S-3 Site, but rapidly decrease to less than $50 \mathrm{mg} / \mathrm{L}$ south of the Oil Landfarm WMA, and are typically highest in the fracturedotminated groundwater flow system at depths greater than $100 \mathrm{ft} b g s$.

The distribution of VOCs in the Maynardville Limestone reflects the relative contributions of several soumce areas and commingling during downgradient transport (Appendix A, Fig. 11). Plume constituents in the upper part of BCV are TCE, cl2DCE, and PCE. Probable source areas are Spoil Axea 1 , the S-3 Site, and possibly the Fire Training Facility located in the Upper East Fork Poplar Creek Hydrogeologic Regime. Major imputs to the plume occur from the Rust Spoil Area (TCE) or a nearby source in the Bear Creek floodplain, the Oil Landfarm HWDU and/or HCDA (TCE and c12DCE), Sanitary Landfill I (111TCA and 11DCA), and discharge from the Bear Creek tributary (NT-7) that traverses BG-A North and A South (c12DCE and 12DCA). The highest concentrations within the plume (i.e., $>300 \mu \mathrm{g} / \mathrm{L}$ ) occur in the deeper groundwater south (down dip) of the BY/BY. These bigh concentrations coincide with the downward vertical hydraulic gradients in the Maynardville Limestone in this area and the major losing reach of middle Bear Creek south of Sanitary Landfill 1.

Radioactivity in the groundwater in the Maynardville Limestone is primarily from uranium isotopes and Tc-99. The extent of these radionuclides is generally delineated by gross alpha activity and gross beta activity, respectively. The distribution of gross beta activity mirrors that of nitrate, indicating a common source of nitrate and Tc-99 (the S-3 Site), mizration along common flowpaths, and similar transport charactetistics in the groundwater (Appendix A, Fig. 11). The sharply increased levels of gross alpha activity in the groundwater downstream (west-southwest) of NT-3 reflect the inflow of uranium isotopes from former sources in the former BY/BY (DOE 1997). 
Most trace metal conlamination in the Maynardville Limestone occurs in the shallow groundwater near the S-3 Site and the BY/BY. Near the S-3 Site, the principal trace metal contaminants are barium, boron, eadmium, copper, lead, mercury, strontium, and uranium. Some of these metals (e.g., cadmium) wete entrained in the highly acidic wastes disposed at the site, and others (e.g., strontium) were dissolved from the underlying bedrock. Trece metal contamination is sporadic in the groundwater at the BY/BY, and the principal contaminants are beryllium, manganese, mercury, nickel, and uraniun (DOE 1997). Boron and uranium are the most common trace metal contatninants in the Aquifer downgradient of the S-3 Site and BY/BY, which indicates that relatively mobile, ionic species of both metals are present in the groundwater.

\subsubsection{Upper East Fork Poplar Creek Hydrogealogic Regime}

Results of several investigations of subsurface contamination in the Upper East Fork Regine, including findings of the CERCLA RI for the UEFPC CA (DOE 1998), show that the principal groundwater contaminants in the regime are: nitrate; trace metals (notably uranium); VOCs, including chlorinated solvents and petroleum hydrocarbons; and several radionuclides, chiefly Tc-99 and uranium isotopes.

A plume of nitrate contamination originating from the former S-3 Ponds extends vertically in the Aquitard at leas $150 \mathrm{ft}$ bgs and laterally at least $5000 \mathrm{ft}$ into the western Y-12 area (Appendix A, Fig. 12). Nitrate concentrations within the plume exceed $10,000 \mathrm{mg}$. As noted previously, nitrate is chemically stable and highly mobile in groundwater, and the elevated levels probably delineate the overall migration pattern for other similarly mobile groundwater contaminants from the former $\$-3$ Ponds. Moreover, the geometry of the nitrate plume indicated by monitoring results for the network of wells located eastsoutheast of the site suggests two principal nigration pathways: (1) relatively rapid migration along fairly short, shallow pathways ( $<30 \mathrm{ft}$ bgs) that typically ferminate in storm drains or other utilities, building sumps, and the buried tributaries and original mainsten of UEFPC; and (2) substantially slower migration along much longer strike-parallel pathways deeper in the bedrock toward basement sumps in Bldgs. 9204-4, 9201-5, and 9204-2 (DOE 1998).

The low $\mathrm{pH}$ groundwater within the contaminant plume adjacent to the former S-3 Ponds contains a diverse mix of metal ions and/or ion-complexes (beryllium, cadmium, cobalt, manganese, metcury, and nickel) that are usually not mobile (or are more readily attenuated) in less acidic groundwater, as well as metals that are mobile under a wider range of groundwater pH conditions (barium, boron, strontium, and uranium). As noted previously, some of these trace metals were entrained in the acidic wastes disposed at the site, and others were dissolved from the underlying saprolite and bedrock. Similarly elevated concentrations of several other trace metals (incfuding boron, cadmium, cobalt, copper, mercury, and uranium) occur in the groundwater near other sources in the Upper East Fork Regime, notably the S-2 Site, but available data do not indicate that extensive plumes of metal ions and/or ion-complexes have developed in the groundwater beyond the inmediate vicinity of these sites (DOE 1998).

Volatile organic compounds are the most pervasive groundwater contaminants in the Upper East Fork Regime (Appendix A, Fig. 12). Chloroethenes (primarily PCE, TCE, and DCE isomers) are the principal components of dissolved VOC plumes in the western and central Y-12 areas. Chloromethanes (primarily carton tetrachloride and chloroform) are printary plume components in the eastern $Y-12$ area. Concentrations of individual plume constiquents in the Aquitard near several source areas, notably the Waste Coolant Processing Area in the central Y-12 area, exceed $1000 \mathrm{\mu g} / \mathrm{L}$ and indicate the presence of DNAPLs in the subsurface. Data for the existing network of Aquifer (Maynardville Limestone) monitoring wells generally define a relatively continuous plume of dissolved VOCs in the water table interval/shallow bedrock that extends castward from the Firc Training Facility in the western Y-12 area, 
underneath New Hope Pond in the eastert Y-12 area, and into Union Valley at least 2000 it east of the ORR boundary (Appendix A, Fig. 12).

Groundwater with radiological contamination occurs primarily in the Aquitard east of the former S-3 Ponds and at Tank 0134-U and Bldgs. 9204-4 and 9201-5. In the Aquifer, radjological contanination occurs near the S-2 Site and immediately upgradient of New Hope Pond (the Uranium Oxide Vault, wells GW-605 and GW-606 vicinity, and the former Oil Skimmer Basin) (Appendix A, Fig. 12). The S-3 Ponds are confirmed sources of uranium isotopes (primarily U-234 and U-238), but Tc-99 concentrations (and gross beta activity) exceed $10,000 \mathrm{pCi} / \mathrm{L}$ and completely dominate the other radiological contaminants within the Eastern S-3 Site Plume. Under the tems of the PCP for the Upper East Fork Regime, Tc-99 is considered a "signature" component of the Eastem S-3 Site Plume because, as noted previousiy, the former S-3 Pouds are the only site at Y-12 that routinely received wastes containing Tc-99. In any case, limited influx of radiological contaminants into the Aquifer (or extensive dilution) is indicated by the greatly decreased levels of gross alphe, gross beta, and isotopic uranium activity in the groundwater downgradient of confirmed source areas (e.g., S-2 Site and the former Oil Skimmer Basin).

\subsubsection{Chestuut Ridge Hydrogeologic Regime}

Operation of the CRSP emplaced a plume of dissolved VOCs in the groundwater that baged on the existing network of wells on Chestnut Ridge, extends at least $2500 \mathrm{ft}$ to the east-northeast along the crest of Chestnut Ridge (parailei with geologic strike) and at least $500 \mathrm{ft}$ to the north and south down the ridge flanks (Appendix A, Fig. 13). The primary components of the VOC plume are 111TCA, 11DCA, and 11DCE near the westem trench area and PCE, TCE, and 12DCE isomers near the eastern trench area. The distribution of the VOCs relative to the respective source areas and the apparent elongation of the plume along the axis of Chestnut Ridge, despite steeper hydraulic gradients down the ridge flanks, suggest primarily strike-parallel lateral transport (west to east) in the groundwater (and possibly vapor phase transport). The maximum depth of vertical migration of the VOCs has not been conclusively determined. but is at least $150 \mathrm{ft} b g s$ in the western trench area, $250 \mathrm{ft}$ bgs near the middle of the site, and $270 \mathrm{ft} b \mathrm{gs}$ downgradient of the eastem trench area (Energy Systems 1996a). Historical data show maximum summed VOC concentrations above $1000 \mu \mathrm{g} / \mathrm{L}$ in wells located adjacent to the waste disposal trenches, but the concentrations rapidly decrease with distance from the site and are less that $100 \mu \mathrm{g} / \mathrm{L}$ in all wells more than $500 \mathrm{ft}$ from the site. Additionally, VOC concentrations in most wells at the CRSP decreased sharply after the installation of the low-permeability cap during RCRA final closure of the site in 1989 (see Sect. 2.3.1).

Although groundwater trangport of the VOCs from the CRSP is primarily from west to east via strikeparallel flowpaths in the bedrock (e.g., bedding-plane fractures), the continued presence of 11 ITCA and 11DCA in the groundwater from a weil (GW-177) at the westerm end of the CRSP indicates that there is a local component of groundwater flow/NOC tansport toward a slight topographic saddle located immediately west-southwest (downhill) of the site. However, extensive westward transport in the groundwater is not supported by the data from the existing network of monitoring wells on Chestrut Ridge.

The western waste disposal trenches at the CRSP are the suspected source of the VOCs (primarily $111 \mathrm{TCA}$ ) detected in wells located approximately $500 \mathrm{ft}$ directly south (GW-796) and $1500 \mathrm{ft}$ eastsoutheast (GW-798) of the site (Appendix A, Fig. 13). Continued detection of VOCs in the groundwater samples from these downgradient wells reflects groundwater transport across geologic strike, possibly via "quickflow" conduits described in Energy Systems (1994b). 
Results of RCRA interim status (1986-1995) and RCRA post-closure detection monitoring (1995-present) at the CRSDB have not confirmed any release of potential goundwater contaminants to the uppermost aquifer at the site. Results of RCRA interim status (1986-1996) and RCRA post-closure detection monitoring (1996-present) at KHQ show sporadic detection of VOCs (carbon tetrachloride, chloroform, and $\mathrm{PCE}$ ) in the monitoring wells located hydraulically downgradient of the site ${ }_{4}$ possibly as a direct consequence of wastes being disturbed during attempts to obtain clean closure of the site in the late 1980s and early 1990s (Energy Systems 1996a). Historical sampling datn for the existing wells at the ECRWP are limited, but do not suggest a relcase of contamitnants to the groundwater has occurred at the site (see Sect. 5.4.3). 


\section{CY 2007 RCRA POST-CLOSURE GROUNDWATER SAMPLING AND ANALYSIS}

This section describes the CY 2007 groundwater sampling and analysis activities performed for the purposes of RCRA post-closure corrective action monitoring at the \$-3 Site, Oil Landfarm, BCBG/WIP, Eastem S-3 Site Plume, and CRSP and RCRA post-closure detection monitoring at the CRSDB, KHQ, and ECRWP. These sampling and analysis activities were implemented under the BJC Water Resources Restoration Program (WRRP) sampling and analysis plan (SAP) for fiscal year (FY) 2007 (BJC 2006). The following subsections provide site-specific information regarding the RCRA post-closure groundwater sampling locations and frequencies, sampling methods, fjeld measurements and laboratory analytes, quality assurance $(\mathrm{QA})$ and quality control (QC) sampling, data management, and data quality objactives (DQO).

\subsection{SAMPLING LOCATIONS AND FREQUENCIES}

The growndwater sampling locations used for the ptronoses of RCRA post-closure groundwater monitoring during CY 2007 are shown in Appendix A, Fig 14 (Bear Creek Regime), Appendix A, Fig. 15 (Upper East Fork Regine), and Appendix A, Fig. 16 (Chestnut Ridge Regime). Site-specific details regarding the monitoring networks and associated sampling frequencies are described in the following subsections.

\subsubsection{S-3 Site, Oil Eandfarm, and Bear Creek Burial Grounds/Walk-In Pits}

The CY 2007 RCRA monitoring well network in the Bear Creek Regine included one of the desigrated point of compliance (POC) wells at the S-3 Site (GW-276), the Oil Landfartn (GW-008), and the BCBG/WIP (GW-046), and the specified network of RCRA plume boundary sampling locations in the regime: wells GW-712, GW-713, and GW-714 and spring SS-6. The selected POC wells are completed at shallow depths ( $30 \mathrm{ft}$ bgs) in the water table interval in the Aquitard (Nolichucky Shale). Conversely, the RCRA plume boundary wells are completed in different hydrostratigraphic intervals in the Aquifer (Maynardville Limestone) at depths ranging from $145 \mathrm{ft}$ bgs (GW-714) to $457 \mathrm{ft}$ bgs (GW-712), and spring SS-6 discharges groundwater from the Maynardville Limestone into the main channel of Bear Creek approximately $400 \mathrm{ft}$ west (downstream) of the RCRA plume boundary wells. Appendix A, Fig. 14 shows the locations of the POC wells at each site and the RCRA plume boundary wells and spring. Construction details for each well are included in Appendix B, Table 7.

Groundwater samples were collected semtannually from each selected POC well at the S-3 Site, Oil Landfarm, and BCBG/WIP and from the shared network of RCRA plume boundary sarmpling locations during CY 2007. Sampling was petformed January 2-3, 2007 (seasonally high flow conditions) and July 2-9, 2007 (scasotally low flow conditions); specific sampling dates and times are included with the corresponding analytical results presented in Appendix $\mathrm{C}$. 


\subsubsection{Eastern S-3 Site Plume}

The CY 2007 RCRA post-closure corrective action monitoring network for the Eastern S-3 Site Plume included one selected POC well (GW-108) and the four designated RCRA plume boundary wells: GW-193, GW-605, GW-606, and GW-733. Completed at a depth of $58 \mathrm{ft}$ bgs, POC well GW-108 yields groundwater from the water table interval in the Aquitard (Nolichucky Shale). Depths of the RCRA plume boundary wells range from less than $20 \mathrm{ft}$ bgs (GW-193) to more than $250 \mathrm{ft}$ bgs (GW-733), and alt of these wells are completed in the Aquifer (Maynardville Limestone) in the water table interval (GW-193), shallow bedrock interval (GW-605), intermediate bedrock interval (GW-606), and deep bedrock interval (GW-733). Appendix A, Fig. 15 stows the locations of the POC well and RCRA plume boundary wells. Construction details for each well are included in Appendix B, Table 7.

Groundwater samples were collected semianmually from the POC well and the RCRA plume boundary wells during $\mathrm{CY} 2007$. Santling was performed January 3-4, 2007 (seasonally high flow conditions) and July 9-10,2007 (seasonally low flow conditions); specific sampling dates and times are included with the corresponding analytical results presented in Appendix D.

\subsubsection{Chestnut Ridge Security Pits}

The CY 2007 RCRA post-closure cortective action monitoring network for the CRSP included upgradient/background well GW-521, POC well GW-177, and the following RCRA plutne boundary sampling locations: spring SCR4.3SP and wells GW-301, GW-557, GW-562, GW-799, GW-801, and $\mathrm{GW}-831$. All of these wells are completed in the (lower) Knox Group at deptls ranging from $92 \mathrm{ft}$ bgs (GW-799) to $200 \mathrm{ft}$ bgs (GW-831). Construction details for each well are included in Appendix B, Table 7. Appendix A, Fig. 16 shows the location of each RCRA well and spring SCR4.3SP, which discharges into a surface drainage feature on the southern flank of Chestnut Ridge.

Grotundwater samples were collected semiannually from the RCRA background well, POC well, and RCRA plume boundary wells and spring during CY 2007. Sampling was performed January 9-16, 2007 (seasonally high flow conditions) and July 11-17, 2007 (seasonally low flow conditions); specific sampling dates and times are included with the corresponding analytical results presented in Appendix E.1.

\subsubsection{Chestnut Rldge Sediment Disposal Basin}

The network of wells designated for RCRA post-closure detection monitoring at the CRSDB includes one upgradient/background well (GW-159) located nothwest of the site and three POC wells located to the south (GW-731) and east (GW-156 and GW-732) of the site (Appendix A, Fig. 16). These wells are all completed in the (lower) Knox Group at total depths ranging frem $157 \mathrm{ft}$ bgs (GW-156 and GW-159) to $190 \mathrm{ft}$ bgs (GW-732). Construction details for each well are included in Appendix B, Table 7.

Groundwater samples were collected amually from the RCRA background well and POC wells during CY 2007. Sampling was performed Januery 8-9, 2007 (seasonally high groundwater flow); specific sampling dates and times are included with the corresponding analytical results presented in Appendix E.2. 
The PCP for the Chestnut Ridge Regime requires annual groundwater sampling for RCRA post-closure detection monitoring at the CRSDB to be performed during altemating seasonally high and low flow conditions. Accordingly, annual RCRA sampling at the CRSDB in CY 2008 is scheduled to be performed during seasonally low groundwater flow conditions (July 2008).

\subsubsection{Kerr Hollow Quarry}

The network of wells desigmated for RCRA post-closure detection monitoring at KHQ includes an upgradient/background well (GW-231) located northwest of the water-filled quarry, and POC wells located to the south (GW-143 and GW-144) and southwest (GW-145) of the site (Appendix A, Fig. 16). These wells are all completed in the (upper) Knox Group at depths ranging from $35 \mathrm{ft}$ bgs (GW-231) to $253 \mathrm{ft} \mathrm{bgs} \mathrm{(GW-143).} \mathrm{Construction} \mathrm{details} \mathrm{for} \mathrm{each} \mathrm{well} \mathrm{are} \mathrm{included} \mathrm{in} \mathrm{Appendix} \mathrm{B,} \mathrm{Table} 7$.

Grotndwater samples were collected annually from the RCRA background well and POC wells during CX 2007. Sampling was performed January 4 and 8,2007 (seasonally high groundwater flow); specific sampling dates and times for each well are included with the corresponding anslytical results presented in Appendix E.3.

The PCP for the Chestrut Ridge Regime requites armual groundwater sampling for RCRA post-closure detection monitoring at $\mathrm{KHQ}$ to be performed during alternating seasonally high and low flow conditions. Accordingly, CY 2008 annual RCRA sampling at the KHQ is scheduled to be performed during seasonally low groundwater flow conditions (July 2008).

\subsubsection{East Chestnut Ridge Waste Pile}

The network of wells designated for RCRA post-closure detection monitoring at the ECRWP (Appendix A, Fig. 16) consists of an upgradient/background well (GW-294) located at the eastern end of the site, and POC wells located downhill of the site to the west (GW-296), north (GW-292 and GW-293), south (GW-161), and southeast (GW-298). Construction details for each well are included in Appendix B, Table 7.

Groundwater samples were collected semiannually from the RCRA background well and each POC well during CY 2007. Sampling was performed Jantuary 22-29, 2007 (seasonally high flow conditions) and July 9-11, 2007 (seasonally low tlow conditions); specific sampling dates and times are included with the corresponding analytical results presented in Appendix E.4.

The PCP for the Chestrut Ridge Regime requires only three of the POC wells to be included in each RCRA sanpling event. However, all of the POC wells were sampled during CY 2007 in order to obtain additional baseline gtoundwater quality data (see Sect. 5.4.3). Beginning in January 2008, wells GW-161, GW-296, and GW-298 will serve as the primary POC wells at the site, with wells GW-292 and GW-293 reserved as replacements for any of the primary $P O C$ wells that may become irreparably damaged or otherwise rendered unusable.

\subsection{SAMPLING METHODS}

The dedicated bladder pump in each well designated for RCRA post-closure groundwater monitoning at the applicable TSD units in the Bear Creek Regime, Upper East Fork Regime, and Chestnut 
Ridge Regime was used to collect unfiltered groundwater samples during each RCRA groundwater sampling event. Sampling was performed in accordance with the low-flow minimal drawdown sempling method (hereafter referenced as low-flow sampling) described in Attachment 7, Section A of the PCP for the Bear Creek Regime; Astachment 6 of the PCP for the Upper East Fork Regime; and Attachment 6.1 of the PCP for the Chestnut Ridge Regirne.

The TDEC in July 1997 approved the low-flow sampling method for RCRA post-closure groundwater monitoring at $\mathrm{Y}+12$ (TDEC 1997), and implementation of this method at Y-12 began in January 1998. Under this method, unfiltered groundwater samples (including duplicates) are collected immediately after field measurements of selected indicator parameters (e.g., groundwater temperature) show stable valtues (minimal variation over four consecutive readings) for the groundwater purged from the well at a rate low enough ( $<300$ milliliters per minute) to induce minimal drawdown of the water level in the well ( $<0.1 \mathrm{ft}$ per quarter-hour). Low-flow sampling promotes groundwater inflow into the well from the waterproducing feature(s) proximal to the pump intake. As shown in Appendix B, Table 7, the intake for the dedicated bladder purmp in most of the RCRA post-closure groundwater wells that were sampled during CY 2007 is located within apptoximately 3 ft of the tespective monitored interval midpoint.

Before January 1998, a "conventional" sampling method approved by the TDEC was used to obtain groundwater samples from the RCRA groumdwater monitoring wells in the Bear Creek Regime, Upper East Fork Regime, and Chestnut Ridge Regime. Under this method, groundwater samples were collected after purging at least three wrell volumes of groundwater at a pumping rate (1-2 gal per minute) that may substantially lower the water level in the well or purge the well dry. Conventional sampling promotes groundwater inflow from water-producing features throughout the screened or open-hole monitored interval in the well, including features that may not be proximal to the pump intake.

The container immersion sampling method (grab sampling) was used to obtain unfiltered groundwater samples from the springs used for RCRA post-closure groundwater monitoring in the Bear Creek Regime (spring SS-6) and Chestrut Ridge Regime (spring SCR4.3SP). Grab sampling was performed in accordance with the technical procedure specified in the PCP for each respective regime.

\subsection{FLEL MEASUREMENTS ANB LABORATORY ANAEYTES}

Field personnel measured the depth to the static water surface in each applicable RCRA well befort collecting any groundwater samples, as required by the respective PCP for the Bear Creek Regime (Appendix B, Table 1), Upper East Fork Regine (Appendix B, Table 2), and Chestnut Ridge Regíme (Appendix B, Table 3). The depth-to-water measurements were obtained and recorded per the corresponding technical procedure specified in each PCP. Field persotmel giso recorded measurements of $\mathrm{pH}$, water temperature, conductivity, turbidity, dissolved oxygen, and oxidation-reduction potential (REDOX) when the groundwater samples were collected from each well and spring used for RCRA postclosure groundwater monitoring in each hydrogeologic regime.

All of the groundwater samples collected for the purposes of RCRA post-closure groundwater monitoring during CY 2007 were placed in appropriate containers provided by the analytical laboratory; preserved in accordance with the analytical method; labeled and logged; and transported in ice-filled coolers to the appropriate analytical laboratory. Fully qualified and trained personnel from the BJC environmental sampling subcontractor (Conmodore Advanced Sciences, me.) were responsible for collecting and transporting the groundwater samples until chain-of-custody control was relinguished to the designated analytical laboratory. 
Two comnercial laboratories performed the analyses of the groundwater samples collected during CY 2007 for the purposes of RCRA post-closure groundwater monitoring in the Bear Creck Regime, Upper East Fork Regime, and Chestnut Ridge Regime: Lionville Laboratory (inorganic analytes, excluding total uranium, and VOCs) and Paragon Laboratories, Inc. (radiological analytes and total uranium). Analytical results are presented in Appendix C (Bear Creek Regime), Appendix D (Upper East Fork Regime), and Appendix E (Chestnut Ridge Regime). These analyses were performed in accordance with the analytical methods specified in the PCP for each regime, and the analytical results wrere reported with the project quantitation levels (PQLs) specified for each analyte in the SAP referenced in Sect. 4. Additionally, as required by the PCP for the Chestnut Ridge Regime (Appendix B, Table 3), laboratory analyses of the groundwater samples collected during CY 2007 from the designated RCRA wells at the CRSDB, CRSP, ECRWP, and KHQ were completed within 60 days of each respective sampling date for each well.

The following subsections provide site-specife details regarding the fjeld measurements and laboratory analyses associated with RCRA post-closure groundwatet monitoting at the S-3 Site, Oil Landfarth, and BCBG/WIP; the Eastem S-3 Site Plume; and the CRSP, CRSDB, KHQ, and ECRWP.

\subsubsection{S-3 Site, Ol Landfarm, and Bear Creek Burlal Gronnds/Walk-In Pits}

Presampling groundwater elevations in the POC wells at the S-3 Site, Oit Landfarm, and BCBGNLP and the RCRA plume boundary wells during each CY 2007 RCRA groundwater sampling event are surmarized below in Table 2 . The corresponding depth-to-water measurements for each well are shown in Appendix C. The presampling groundwater elevations in each well are consistent with those recorded during previous RCRA groundwater sampling events and generally reflect the seasonal water table fluctuations that are typically evident in BCV west of $Y-12$, with groundwater elevations evident during January 2007 (i.e., seasonally high flow conditions) being from $1.5 \mathrm{ft}$ (GW-046) to $2.14 \mathrm{ft}$ (GW-008) higher than evident during July 2007 (i.e., seasonally low flow conditions).

Table 2. CY 2007 presampling gronndwater elewations in wells used for RCRA post-closure corrective action monitoring at the \&3 Site, Oil Landfarm, and BCBG/WTP

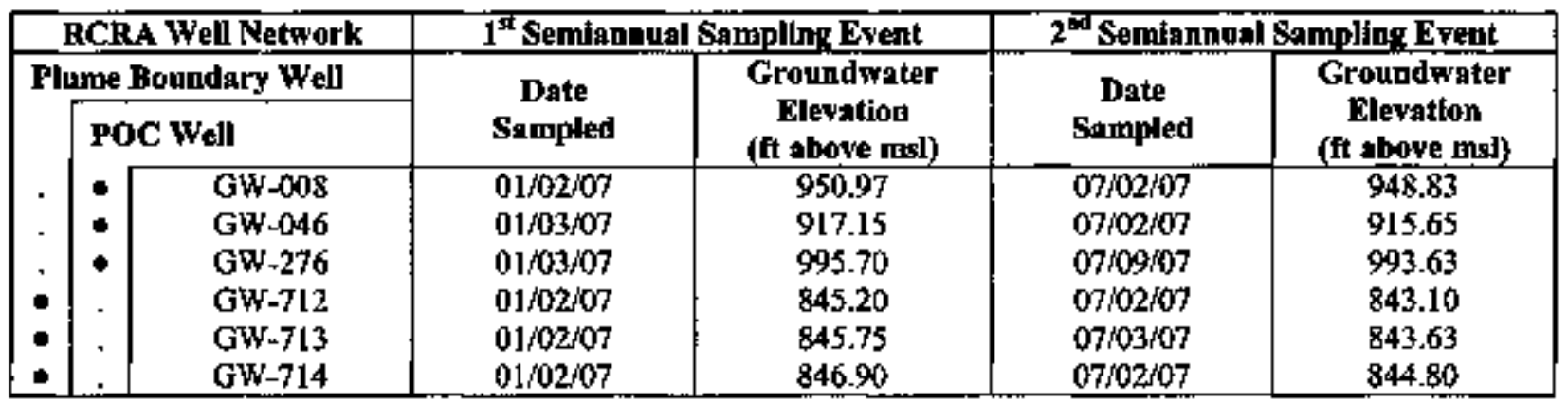

The groundwater samples collected from the selected POC wells at the \$-3 Site (GW-276), Oil Landfarm (GW-008), and BCBG/WIP (GW-046) were analyzed for eack respective suite of inorganics, VOCs, and radioanalytes that the PCP for the Bear Creek Regime designates as RCRA groundwater target compounds for each site (Appendix B, Table 8). Complete analytical results are in Appendix C. 
Groundwater samples collected from wells GW-712, GW-713, and GW-714 and from spring SS-6 were analyzed for the suite of inorganics, VOCs, and radioanalytes that the PCP for the Bear Creek Regime designates as RCRA groundwater target compounds for the RCRA plume boundary sampling locations (Appendix B, Table 8). Complete analytical results are in Appendix C.

\section{4,3.2 Eastern S-3 Site Plume}

Presampling groundwater elevations in the POC well and RCRA plume boundary wells for the Eastern S-3 Ponds Plume during each CY 2007 RCRA groundwater sampling event are sumuarized below in Table 3. The corresponding depth-to-water measurements for each well are presented in Appendix D. These presampling groundwater elevations in each well are similar to those recorded during previous RCRA groundwater sampling events, with fairly minor ( $<1 \mathrm{ft}$ ) seasonal water table fluctuations goundwater elevations evident in each well except GW-733 (2.23 ft), probably reflecting the minimal surface water recharge that occurs in areas with extensive impervious cover (e.g., buildings).

Table 3. CY 2007 presampling groundwater elevations in wells used for RCRA post-closure corrective action monttoring at the Eastern S-3 site PIume

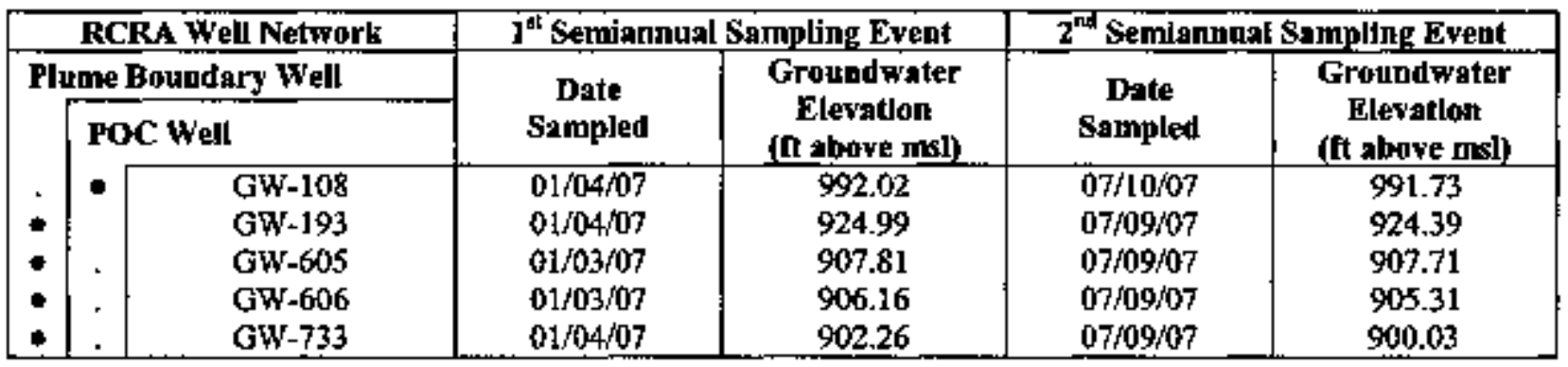

The groundwater samples collected from POC well GW-t08 were analyzed for the inorganics, VOCs, and radioanalytes that the PCP for the Upper East Fork Regime designates as RCRA groumdwater target compounds for the POC wells at the Eastern S-3 Site Plume (Appendix B. Table 9). Note that the total uranium concentrations reported for this well were calculated from isotopic uranium measurements and specific activities for each isotope. This is because very high calciun concentrations ( $1000 \mathrm{mg} / \mathrm{L}$ ) in the groundwater samples from the well cause substantial analytical interferences for the kinetic phosphorescent analysis method used to perform the uraniun analyses (ThermoNUtech 1999).

The groundwater samples collected from wells GW-193, GW-605, GW-606, and GW-733 were analyzed for Tc-99, which is the only analyte that the PCP for the Upper East Fork Regime designates as a RCRA groundwater target compound for these wells because (as noted in Sect. 3.4.2) Tc-99 is considered the "signature" component of the Eastern S-3 Site Plume.

\subsubsection{Chestnut Ridge Secnrity Pits}

The CY 2007 presampling groundwater elevations in the RCRA backgound well, POC well, and RCRA plume boundary wells for the CRSP are summarized below in Table 4. The corresponding depth-to-water measurements for each well are presented in Appendix E.1. The presampling groundwater elevations are similar to those recorded for each well during ptevious RCRA jroundwater sampling events and show seasonal water-table fluctuations ranging from less than $0.5 \mathrm{ft}(\mathrm{GW}-177$ and $\mathrm{GW}-557)$ to more than $2 \mathrm{ft}$ (wells GW-799 and GW-801). 
Table 4. CY 2007 presampling ground water elevations in wells used for RCRA post-clesure corrective action montoring at the CRSP

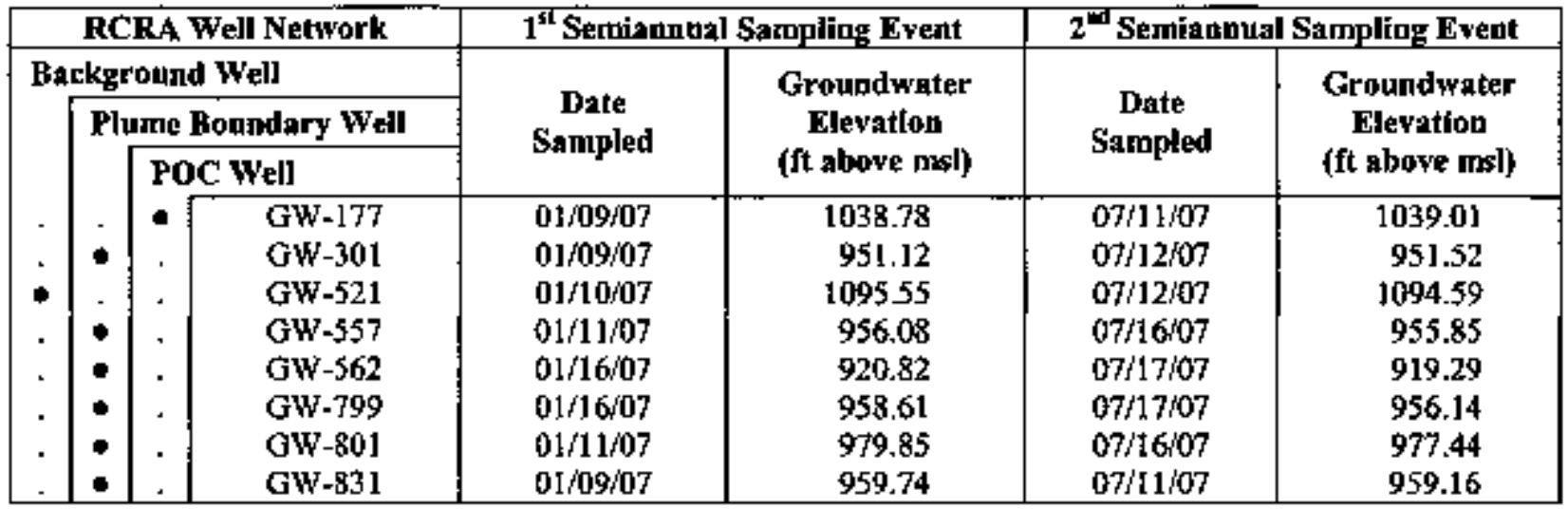

The groumdwater samples collected from the RCRA background well and the POC well during CY 2007 were analyzed for the inorganics, VOCs, and radioanalytes designated as site-specific RCRA groundwater target compounds for the CRSP (Appendix B, Table 10). The PCP for the Chestnut Ridge Regime requires the groundwater samples from the RCRA plume boundary wells and spting SCR4.3SP to be analyzed for the VOCs designated as RCRA groundwater target compounds, which are the only confirmed components of the groundwater contaminant plume originating from the CRSP (see Sect. 3.4.3). Anslytical results are in Appendix E.1.

\subsubsection{Chestnut Ridge Sediment Disposal Basin}

The CY 2007 presampling groundwater elevations in the RCRA wells at the CRSDB, stmmerized below in Table 5, are similar to those recorded during previous RCRA groundwater sampling events and, as required by the PCP for the Chestnut Ridge Regime (Appendix B, Table 3), demonstrate that the POC wells at the CRSDB were hydraulically downgradient of the site when sampling was performed.

Table 5. CY 2007 presgmpling grourdwater elevatians in wells used for RCRA post-closure detection monitoring at the CRSDB

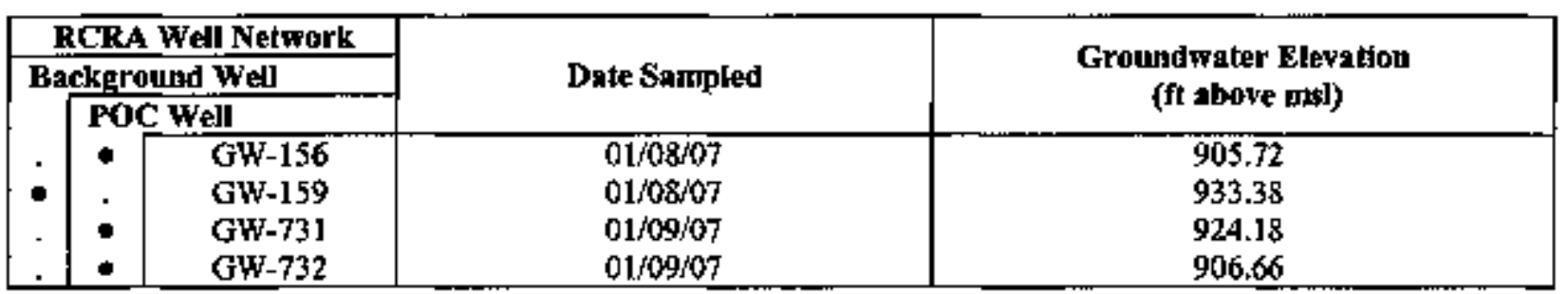

The groundwater samples collected from each of the above-listed RCRA wells during CY 2007 were analyzed for the trace metals that the PCP for the Chestnut Ridge Regime designates as RCRA groundwater target compounds for the CRSDB (Appendix B, Table 10). Analytical results for the groundwater samples from each well are in Appendix E.2. 


\subsubsection{Kerr Hollow Qnarry}

The CY 2007 presampling groundwater elevations in the RCRA wells at KHQ, summarized below in Table 6, are similar to those recorded during previous RCRA sampling events. As shown below, the groundwater elevations in POC wells GW-143 and GW-145 were higher then evident in background well GW-231. However, these wells were sampled four days apart, and 1.33 in. of rain (as measured at a rain gauge located at the west end of the Y-12 Complex) occurred during this period ( 0.26 in. and 1.07 in. on January $\$$ and 7,2007 , respectively). Thus, the difference between the groundwater elevations probably reflects the response to techarge associated with the rainfall.

Table 6. CY 2007 presaneling groundwater elevations in wells used for RCRA post-elosure detection manltoring at KHQ

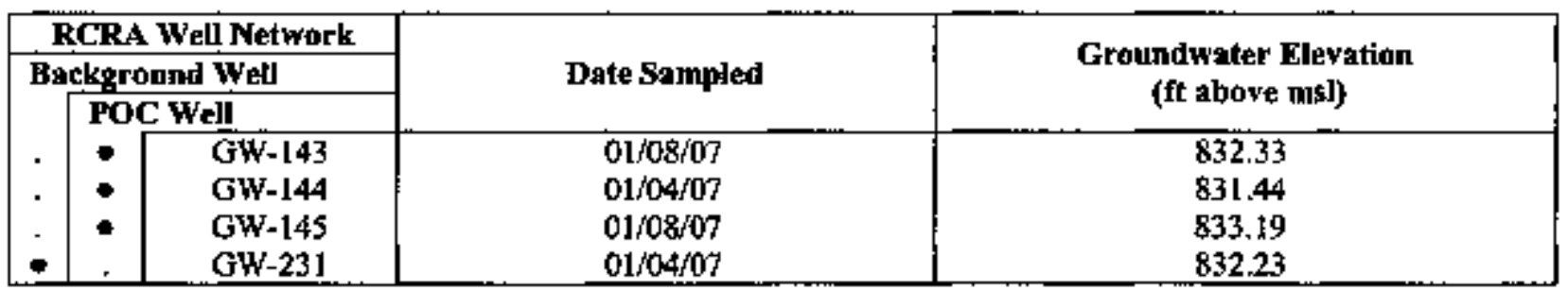

The groundwater samples collected from each of the above-listed RCRA wells during CY 2007 were analyzed for the trace metals, VOCs, and radjoanalytes that the PCP for the Chesinut Ridge Regime designates as RCRA groundwater target compounds for $\mathrm{KHQ}$ (Appendix B, Table 10). Analyticat results for the groundwater samples from each well are in Appendix E.3.

\subsubsection{East Chestnut Ridge Waste Pile}

The CY 2007 presampling groundwater elevations in the RCRA background well and POC wells at the ECRWP are sumtnarized below in Table 7. The corresponding depth-to-water measurements for each well are presented in Appendix E.4. The presampling groundwater elevations show seasonal water table fluchuations ranging from $1.15 \mathrm{ft}$ (GW-296) to $6.03 \mathrm{ft}$ (GW-294) and demonstrate, as required by the PCP for the Chestnut Ridge Regime (Appendix B, Table 3), that the POC wells at the ECRWP were hydraulically downgradient of the site during each RCRA semiannual groundwater sampling event.

Table 7. CY 2007 presampling groundwater elevatlons in wells used for RCRA past-closure detection monitoring at the ECRWP

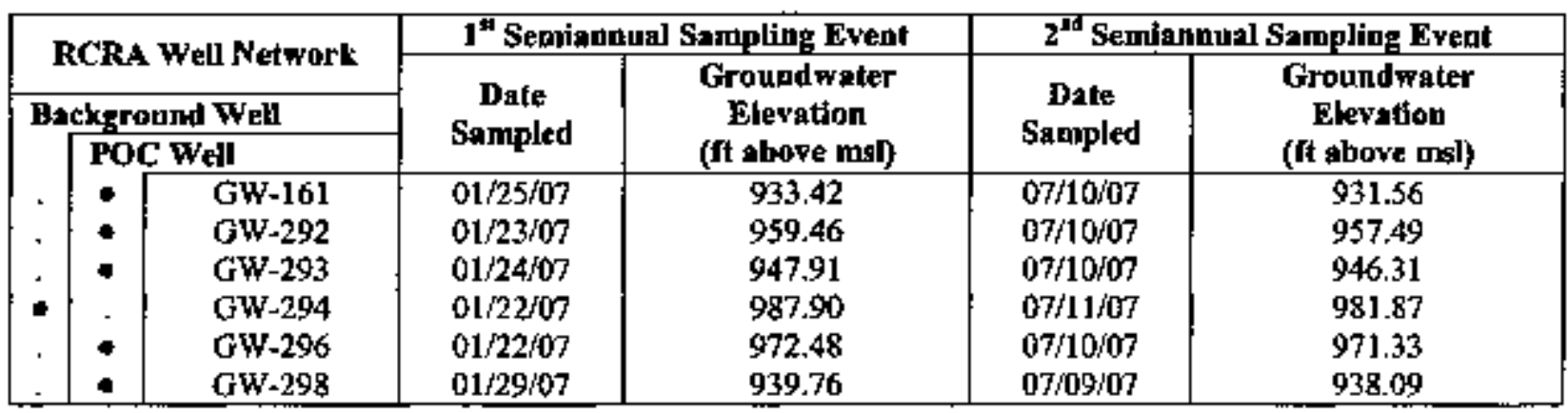


The groundwater samples collected from the RCRA background well and POC wells during CY 2007 were analyzed for the trace metals, VOCs, and radioanalytes that the PCP for the Chestnut Ridge Regime designates as RCRA groundwater target compounds for the ECRWP (Appendix B, Table 10). Analytical results for each well are in Appendix E.4.

The RCRA groundwater target compounds designated for the ECRWP were identified from an evaluation of the analytical resuits for the constituents that have been detected in samples of leachate from the site (see Sect. 6). However, as listed in Attachment 7.1, Table 7.1-1 (page 7.1-2) of the PCP for the Chestnut Ridge Regime, the VOCs identified as RCRA groumdwater target compounds include chloromethane, which has nol been detected in the leachate samples collected to date, but do not include chloroethane, which has been detected in several of the leachate samples. Listing chloromethane instead of chloroethane appears to be a typographical error and should be corrected as a Class 1 modification to the PCP.

\subsection{QUALITY ASSURANCE/QUALITY CONTROL SAMPLING}

The QAVCC samples associated with CX 2007 RCRA post-closure groundwater monitoring in the Bear Creek Regine, Upper East Fork Regime, and Chestnut Ridge Regime include a total of 23 laboratory blanks and 39 trip blanks (Appendix B, Table 11). The laboratory blanks were samples of deionized water that were prepared at the applicable laboratory and analyzed in conjunction with groundwater samples from one or more RCRA sampling locations. The trip blanks were samples of deionized water that were transported in each cooler that contained RCRA groundwatet samples collected for VOC analyses. Each laboratory blank and trip blank was analyzed for a suite of VOCs that ineludes all the organics designated as RCRA groundwater target compounds for the applicable TSD units in the Bear Creek, Upper East Fork, and Chestnut Ridge hydrogeologic regimes.

At least one of the following VOCs was detected in $32(82 \%)$ of the trip blanks and in each of the laboratory blanks: acetone, bromoform, 2-butanone, chłoroform, chloromethane, dibromochloromethane, 1,4-dichlorobenzene, ethylbenzene, 2-hexanone, methylene chloride, styrene, tolutene, 1,2,4-trichlorobenzene, and xylenes. Of these, acetone and methylene chloride (common laboratory reagents) were detected the most frequently, with one or both compounds detected in all but one of the laboratory blank samples and in $27(69 \%)$ of the trip blank samples. Estimated concentrations of $4 \mu \mathrm{g} L$ or less were reported for each VOC except acetone, which was detected at maximum concentrations of $5 \mathrm{\mu g} / \mathrm{L}$ in the laboratory blanks and $12 \mathrm{\mu g} / \mathrm{L}$ in the trip blanks, respectively (Appendix B, Table 12). These findings suggest systemic contanination of the QA/QC samples (and many of the associated groundwater samples) by methylene chloride and acetone during preparation, handling, analysis, or storage in the applicable laboratory.

\subsection{DATA MANAGEMENT}

The RCRA post-closure groundwater monitoring data obtained during CY 2007 at the applicable TSD units in the Bear Creek Regime, Upper East Fork Regime, and Chestrut Ridge Regime were mantaged in accordance with the WRRP data management protocols and maintained in the Project Environmental Measurement System (PEMS) database. The BJC environmental sampling subcontractor initially prepopulated the PEMS database with information (e.g., sampling locations and laboratory analytes) specified in the SAP referenced in Sect. 4. As sampling activities progressed in accordance with the SAP, the BJC environmental sampling subcontractor manually input the associated field measurements and chain-of-custody information into the pre-populated PEMS database. The cotresponding analytical results for each sampling location were loaded into the PEMS database by the laboratory that performed the 
specificd analyses. The applicable laboratory then transfcred hardeopy reports containing the analytical results to the BJC Sample Management Organization that subsequently: (1) resolved any diserepancies between the PEMS database and the corresponding hardcopy reports; (2) verified that the field measurements and laboratory analytes specified for each sampling location were performed; and (3) reviewed the associated chain-of-custody information, analytical tumaround times, and sample holding times. The RCRA post-closure groundwater monitoring data presented in this report were prepared from data files extracted from the PEMS database. After all data were verified and validated, as appropriate, they were uploaded to the Oak Ride Environmental Information System for long-term archival.

\subsection{DATA QUALTTY OBJECTTVES EVALUATION}

Evaluation of the CV 2007 RCRA post-closure groundwater monitoring data for applicable TSD sites in the Bear Cteek Regime, Upper East Fork Regime, and Chestnut Ridge Regitne was based on results that theet applicable DQO criteria. The screening process used to identify results that do not meet applicable DQOs involved: (1) comparison of the corresponding analytical results for duplicate groundwater samples; (2) identification of false-positive VOC tesults; (3) comparison of each radioanalyte result to the corresponding minimum detectable activity (MDA) and associated total propagated uncertainty (TPU); and (4) conparison for consistency with available historical monitoring data for each applicable RCRA sampling location.

\section{Duplicate Samples}

Duplicate groundwater samples were collected from the following wells included in the RCRA groundwater sampling event during CY 2007: RCRA plume boundary wells for the Bear Creek Regime (GW-713), the Eastem S-3 Site Plume (GW-605), and CRSP (GW-301); POC wells at the CRSDB (GW-156) and ECRWP (GW-293); and the RCRA background well at KHQ (GW-231). Cormesponding analytical results for duplicate groundwater samples that differ by an order of magnitude or more ate considered unusable. No such differences are evident between the duplicate sample results for any of the above listed RCRA wells; see data in Appendix C (GW-713), Appendix D (GW-605), and Appendix E (GW-156, GW-231, GW-293, and GW-301).

\section{False-Positive VOC Results}

False-positive results for VOCs (i.e., potential sampling and/or analytical artifacts) are considered the same as non-detect values (i.e., zero concentration) for the purposes of quantitative evaluation. Such results are defined as VOC concentrations reported for groundwater samples that are less than the respective blank qualification result (BQR) calculated from the associated laboratory and trip blank sample data. The BQRs for acetone, methylene chloride, toluene, and 2-butanone (common laboratory reagents) represent the highest concentration in either blark sample multiplied by a factor of 10 , and the BQRs for all other VOCs are similarly calculated using a factor of 5 (EPA 1988). All false-positive VOC results are flagged with a qualifier (FP1 for false-positive results identified from laboratory BQRs or FP2 for false-positive results identified from trip BQRs).

False-positive results for VOCs that are RCRA groundwater target compounds were reported for one or more of the groundwater samples collected during CY 2007 from: the upgradient/background well at the ECRWP (GW-294); POC welts for the ECRWP (GW-161, GW-292, GW-293, GW-296, and GW-298), 
the Eastem S-3 Site Plume (GW-108), and the S-3 Site (GW-276); and the RCRA plume boundary sampling locations in the Bear Creek Regime (wells GW-712, GW-713, and GW-714 and spring SS-6). As shown below in Table 8, the false-positive results are for acetone and methylene chloride, all the concentrations being below $10 \mu \mathrm{g} / \mathrm{L}$ (only two results exceed $5 \mu \mathrm{g} / \mathrm{L}$ ), with just over half (12 of 22) identified from laboratory $\mathrm{BQRS}$. The ubiquitous detection of one or both compounds in the laboratory blanks and trip blanks associated with RCRA post-closure groundwater tnonitoring during CY 2007 suggest that these results are properly considered analytical artifacts.

Table 8. CY 2007 false-posittve results for VOCs that are RCRA groundwater target compounds

\begin{tabular}{|c|c|c|c|c|c|c|}
\hline \multirow{2}{*}{$\begin{array}{c}\text { RCRA } \\
\text { Groundwater } \\
\text { Target Compound }\end{array}$} & \multirow{2}{*}{$\begin{array}{c}\text { RCRA } \\
\text { Location }\end{array}$} & \multirow{2}{*}{$\begin{array}{c}\text { Date } \\
\text { Sampled }\end{array}$} & \multirow{2}{*}{$\begin{array}{l}\text { Result } \\
\text { ( } \mu \mathrm{J} / \mathrm{L})\end{array}$} & \multicolumn{2}{|c|}{$\operatorname{BQR}(\mu \mathrm{HL})$} & \multirow{2}{*}{$\begin{array}{c}\text { QA/QC } \\
\text { Flag }\end{array}$} \\
\hline & & & & Lab. Blank & Trip Blank & \\
\hline Acetone & GW-108 & $01 / 04 / 07$ & $9 \mathrm{~J}$ & 20 & 20 & FP1 \\
\hline Acetone & GW-108 & $07 / 10 / 07$ & $8 \mathrm{~J}$ & 0 & 20 & FP2 \\
\hline Acctonc & GW-276 & $01 / 03 / 07$ & $3 \mathrm{~J}$ & 20 & 30 & FP2 \\
\hline Methylene chloride & GW-161 & $01 / 25 / 07$ & $1 \mathrm{~J}$ & 10 & 20 & FP2 \\
\hline Methylene chloride & GW-276 & $01 / 03 / 07$ & $3 \mathbf{J}$ & 50 & 30 & FP1 \\
\hline Methylene chloride & GW-276 & $07 / 09 / 07$ & $1 \mathrm{~J}$ & 10 & 30 & FP2 \\
\hline Methylene chloride & GW-292 & $01 / 23 / 07$ & $3 \mathrm{~J}$ & 20 & 30 & FP2 \\
\hline Methylene chloride & GW-292 & $07 / 10 / 07$ & $1 \mathrm{~J}$ & 7 & 10 & FP2 \\
\hline Methylene chloride & GW-293 & $01 / 24 / 07$ & $\mathbf{J} \mathrm{J}$ & 10 & 10 & FP1 \\
\hline Methylene chloride & GW-293 & $07 / 10 \% 07$ & 2 & 10 & 10 & FPl \\
\hline Methylene chloride & GW-294 & $01 / 22 / 07$ & $4 \mathrm{~J}$ & 10 & 40 & FP2 \\
\hline Methylene chloride & $G W-296$ & $0 \mathrm{~J} / 22 / 07$ & $3 \mathrm{~J}$ & 10 & 40 & FP2 \\
\hline Methylene chloride & GW-296 & $07 / 10 / 07$ & I & 9 & 10 & FP2 \\
\hline Methyleme chloride & $G W-298$ & $01 / 29 / 07$ & 21 & 20 & 20 & FP1 \\
\hline Methylene chloride & GW-712 & $01 / 02 / 07$ & $3 \mathrm{~J}$ & 30 & 30 & FP1 \\
\hline Methylene chloride & GW-712 & $07 / 02 / 07$ & 13 & 10 & 10 & FP1 \\
\hline Methylene chloride & GW-713 & $01 / 02 / 07$ & $2 \mathrm{~J}$ & 30 & 30 & FP1 \\
\hline Methylene chlorite & GW-713 & $07 / 03 / 07$ & $2 \mathbf{3}$ & 10 & 10 & FP1 \\
\hline Methylene chloride & GW-714 & $01 / 02 / 07$ & 23 & 30 & 30 & FP1 \\
\hline Methylene chloride & GW-714 & $07 / 02 / 07$ & 13 & 10 & 10 & FP1 \\
\hline Methylene chloride & SS-6 & $0 \mathrm{~J} / 03 / 07$ & 43 & 30 & 40 & FP2 \\
\hline Methylene chloride & SS-6 & $07 / 02 / 07$ & 19 & 10 & 0 & FP1 \\
\hline
\end{tabular}

\section{Radialogical Analyses}

Aralytical results for gross alpha activity, gross beta activity, and radioisotopes are qualified as unusable if the reported activity exceeds the specified MDA, but not the associated TPU reported with each result. The TPU expresses the degree of analytical uncertainly and is defined as twice the standard deviation for sample activity. The CY 2007 RCRA post-closure groundwater monitoring data include only two such results: the very low levels of U-235 $(0.203 \mathrm{pCl} / \mathrm{L})$ and $U-238(0.268 \mathrm{pCi} / \mathrm{L})$ reported for the groundwater sample collected from RCRA plume boundary well GW-713 in January 2007 slightly exceed the corresponding $\mathrm{MDA}(0.184 \mathrm{pCi} / \mathrm{L}$ and $0.182 \mathrm{pCi} / \mathrm{L}$, respectively), but not the associated TPU (0.241 pCi/L and $0.272 \mathrm{pCi} / \mathrm{L}$, respectively). 


\section{Historical Data Comparison}

The CY 2007 analytical results were evaluated for consistency with historical monitoring data for each applicable RCRA post-closure groundwater monitoring location in the Bear Creek Regime, Upper East. Fork Regime, and Chestnut Ridge Regime. For the purposes of this evaluation, a "Q" (questionable) dataevaluation qualifier is assigned to analytical results that are either less than one half the historical minimum value for the analyte, or are more than $2 \mathrm{X}$ the historical maximum value for the analyte. Bascd on these criteria, Q qualifiers were assigned to the following CY 2007 sampling results:

- Total concentrations of chromium $(0.01 \mathrm{mg} / \mathrm{L})$, iron $(0.21 \mathrm{mg} / \mathrm{L})$, and nickel $(0.0541 \mathrm{mg} / \mathrm{L})$ reported for the sample collected from ECRWP POC well GW-292 in January 2007 and the chromium $(0.0257 \mathrm{mg} / \mathrm{L})$ and iron $(0.588 \mathrm{mg} / \mathrm{L})$ detected in the sample collected from this well in July 2007 . Chronium was not detected in the 21 samples previously collected from the weil and nickel was detected in only one of these samples (0.013 mg/L in August 1991). Both CY 2007 sampling results for total iron substantially exceed the historical maximum concentration (0.059 m/L in August 1993).

- The total magnesium concentration reported for the sample collected from ECRWP POC well GW-161 in July 2007 (0.262 mgL) substantially exceeds the historical maximum concentration (0.03 mg/L in September 1992). 


\section{CY 2007 RCRA POST-CLOSURE GROUNDWATER MONITORING DATA EVALUATION}

The following sections describe results of the annual evaluations of the RCRA post-closure groundwater monitoring data that are required by the respective PCPs for the Bear Creek Regime (Appendix B, Table 1), Upper East Fork Regime (Appendix B, Table 2), and Chestnut Ridge Regime (Appendix B, Table 3). Collectively, the PCPs require annual evaluation of: (1) the groundwater flow direction and rate in the uppermost aguifer at each specified TSD unit; (2) contaminant concentration trends in the groundwater from POC wells at the S-3 Site, Oil Landfarm, BCBG/WIP, Eastern S-3 Site Plume, and CRSP; (3) continued contaminant plume migration based on sampling results for the designated RCRA plume boundary monitoring locations in each hydrogeologic regime; and (4) evidence of contaminant releases to the groundwater at the CRSDB, ECRWP, and KHQ based on statistical analysis of the respective RCRA post-closure detection monitoring data.

\subsection{GROUNDWATER FLOW DIRECTION AND RATE}

Estimates of representative groundwater flow rates in the uppermost aquifer at the TSD tnits in BCV (Bear Creek Regime and Upper East Fork Regime) and the section of Chestnut Ridge south of Y-12 (Chestrut Ridge Regime) are described in the following subsections. The wide range of estimated flow rates probably occurs at vartious times under various conditions. However, the relatively limited migration of most groundwater contaminants in the Bear Creek Regime, Upper East Fork Regime, and Chestmut Ridge Regime suggests that the lower flow rates dominate (particularly in the Aquitard bedrock intervals) and that attenuation processes greatly reduce contaminant transport relative to groundwater flow rates.

\subsubsection{Bear Creek Valley}

Depth-to-water measurements obtained during April 2007 (i.e., seasonally high groundwater flow conditions) for 64 monitoring wells in the Bear Creek Regime (Appendix B, Table 13) and 55 monitoring wells in the Upper East Fork Regime (Appendix B, Table 14) were used to determine: (1) representative groundwater elevations in the vicinity of the S-3 Site, Oil Landfarm, BCBG/WIP, and Eastern S-3 Site Plume; (2) site- and regime-wide groundwater flow directions; and (3) horizontal hydraulic gradjent values needed to calculate groundwater flow rates. The groundwater elevations determined from the depth-to-water measurements recorded during each CY 2007 RCRA sampling event were not used for these purposes.

In the Bear Creek Regime, isopleths of groundwater surface elevations indicate southwesterly flow in the Aquitard, across geologic strike, toward the Aquifer (Maynardville Limestone), with more westerly flow in the Maynardvitle Limestone, parallel with geologic strike, toward the west end of BCV (Appendix A, Fig. 8). In the Upper East Fork Regime, isopleths of groundwater surface elevations generally show southeasterly flow in the Aquitard (across geologic strike) toward the Aquifer (Maytardville Limestone), and easterly (parallel with geologic strike) flow in the Maynardville Limestone toward the east end of Y-12 (Appendix A, Fig. 9). These findings do not indicate any significant change in the relative directions of groundwater flow in the uppermost aquifer at the S-3 Site, Oil Landfarm, BCBGNWIP, and the Eastern S-3 Site Plutre. 
Rates of groundwater flow were estimated for the water table and shallow bedrock intervals in the Aquitard, which underly the S-3 Site, Oil Landfarm, BCBG/WIP, and Eastern S-3 Site Plume, and the shallow karst network in the Aquifer, which is the primary pathway for groundwater transport of contaminants in the Bear Creek Regime and the Upper East Fork Regime. Groundwater flow rates in each hydrogeologic unit were estimated using the modified Darcy equation: $V=\mathbf{K} J \mathbf{\eta}$, where $V$ is the flow velocity, $\mathbf{K}$ is the hydraulic conductivity of the medium, $I$ is the horizental hydraulic gradient, and $\boldsymbol{\eta}$ is the effective porosity. The calculated flow rates represent average velocities in the Aquitard and the Aquifer, essuming each hydrogeologic unit functions as an equivalent porous medium. Flow rates were not estimated for the stomflow zone in either hydrogeologic unit because most waste sources in each regime lie below this zone. Rates of groundwater flow in the intermediate and deep bedrock intervals in the Aquitard and the Aquifer also were not estimated, but are probably as low as a few centimeters per year in the Aquitard (Energy Systerns 1992a).

Results of statistical analysis of hydraulic test data for wells in BCV indicate hydraulic conductivity values of 0.03 to $3.25 \mathrm{ft}$ per day (fv/d) at shallow depths (water table inferval) in the geologic formations that comprise the Aquitard (Connell and Bailey 1989). In the shallow bedrock interval in the Aquitard, representative hydraulic conductivities are $0.0008 \mathrm{ft} / \mathrm{d}$ for matrix intervals (Energy Systems 1989a). $0.15 \mathrm{ft} / \mathrm{d}$ for permeable intervais (Energy Systems 1989a), and $0.6 \mathrm{ft} / \mathrm{d}$ for the continuum of permeable intervals (Energy Systems 1992b). Substantially higher hydraulic conductivity is evident in the shallow karst network in the Aquifer, with an average hydraulic conductivity of $22 \mathrm{ft} / \mathrm{d}$ indicated by falling-head permeability test results for wells completed in the Maynardville Limestone in BCV west of Y-12 (Energy Systems 1989b), and a flow rate of $200 \mathrm{ft} / \mathrm{d}$ determined from results of a dye-tracer study in Bear Creek (Energy Systems 1989c). These estimated rates of groundwater flow may not be representative of hydraulic conductivity at shallow depths in the Aquitard and the Aquifer throughout mich of the Upper East Fork Regime because of the extensive alteration of the shallow subsurface that occurred during construction of the Y-12 operations and support facilities.

Representative horizontal hydraulic gradients in upperrnost aquifer at the S-3 Site, Oil Landfarm, BCBG/WT, and the Eastern S-3 Site Plume were determined from groundwater elevations in selected monitoring wells completed at shallow depths (water table interval) in the Aquitard formations that subcrop beneath each site. Also, selected wells completed at similarly shallow depths in the Maynardville Limestone were used to determine representative horizontal hydraulic gradients in the Aquifer throughout the Bear Creek Regime and Upper East Fork Regime. As shown below in Table 9, calculated horizonta] hydraulic gradients in the Aquitard range from 0.029 near the Oil Landfarm to 0.047 at the former S-3 Ponds (Eastern S-3 Site Plume), with gradients in the Aquifer being near 0.01 in both the Upper East Fork Regime and Bear Creek Regime.

Table 9. Representatlve horlzontal hydraule gradients in the uppermost aquifer at the S-3 Site, Oil Landfarm, BCBG/WT, and Eastern S-3 Site Plume, Aprit 2007

\begin{tabular}{|c|c|c|c|c|c|}
\hline \multicolumn{3}{|c|}{$\begin{array}{l}\text { Hydrogeologic Unit, Site, and } \\
\text { Monitoring Well No. }\end{array}$} & $\begin{array}{l}\text { Groundwater Elevation } \\
\text { (ft wbove ms) }\end{array}$ & $\begin{array}{c}\text { Lateral } \\
\text { Distance (it) }\end{array}$ & $\begin{array}{c}\text { Horizontal } \\
\text { Hydraulic Gr } * \text { dient }(I)\end{array}$ \\
\hline \multirow[t]{4}{*}{ Aquitard } & S-3 Site & $\begin{array}{l}\text { GW-276 } \\
\text { GW-115 }\end{array}$ & $\begin{array}{r}994.73 \\
1043.44\end{array}$ & 1154.1 & 0.042 \\
\hline & Oil Landfarm & $\begin{array}{l}\text { GW-008 } \\
\text { GW-001 }\end{array}$ & $\begin{array}{l}951.09 \\
966.05\end{array}$ & 515,4 & 0.029 \\
\hline & ВСВGЛVIP & $\begin{array}{l}\text { GW-291 } \\
\text { GW-287 }\end{array}$ & $\begin{array}{l}937.13 \\
917.75\end{array}$ & 565.8 & 0.034 \\
\hline & $\begin{array}{r}\text { Eastem S-3 Site } \\
\text { Plume }\end{array}$ & $\begin{array}{l}\text { GW-108 } \\
\text { GW-261 }\end{array}$ & $\begin{array}{r}991.97 \\
1031.82\end{array}$ & 851.5 & 0.047 \\
\hline
\end{tabular}


Table 9. (continued)

\begin{tabular}{|c|c|c|c|c|c|}
\hline \multicolumn{3}{|c|}{$\begin{array}{l}\text { Hydrogeologic Unit, Stte, and } \\
\text { Monftoring Well No. }\end{array}$} & $\begin{array}{c}\text { Groundwater Elevation } \\
\text { (it above msl) }\end{array}$ & $\begin{array}{c}\text { Lateral } \\
\text { Distonce (ft) }\end{array}$ & $\begin{array}{c}\text { Horizontal } \\
\text { Hydraulic Gradient }(I)\end{array}$ \\
\hline \multirow[t]{2}{*}{ Aquifer } & $\begin{array}{r}\text { Bear Creek } \\
\text { Regime }\end{array}$ & $\begin{array}{l}\text { GW-309 } \\
\text { GW-065 }\end{array}$ & $\begin{array}{l}967.50 \\
959.72\end{array}$ & 1066.3 & 0.007 \\
\hline & $\begin{array}{r}\text { Upper East } \\
\text { Fork Regime }\end{array}$ & $\begin{array}{l}G W-617 \\
G W-193\end{array}$ & $\begin{array}{l}971.61 \\
925.15\end{array}$ & 4802.8 & 0.01 \\
\hline
\end{tabular}

Several studies and evaluations of available hydrologic data provide estimates of the effective porosity of the geologic formations that comprise the Aquitard, with values ranging from 0.00035 (Energy Systems 1992b) to 0.099 (Energy Systems 1996b). Estimates of effective porosity in the Aquifer (Maynardville Limestone and Copper Ridge Dolomite) range from 0.0006 to 0.0813 (Energy Systems 1997b).

Based on range of input values for hydraulic conductivity, hydraulic gradient, and effective potosity described above, and on the assumptions inherent to the modified Darcy equation, calculated rates of groundwater flow in the Aquitard at the S-3 Site, Oil Landfarm, BCBG/WP, and the Eastem S-3 Site Plume, summarized below (Table 10), range from $0.07 \mathrm{ft}$ per year $(0.0002 \mathrm{ft} / \mathrm{d})$ to approximately $77 \mathrm{ft} / \mathrm{d}$. A comparably wide range of groundwater flow rates likewise is indicated for the Aquifer (Maynardville Limestone) in the Bear Creek Regime and the Upper East Fork Regime.

Table 10. Calculated rates of gronndwater Dow in the uppermost aquifer at the S-3 Site, Oil Landfarm, BCBG/WIP, and Eastern S-3 Stte Plume

\begin{tabular}{|c|c|c|c|c|c|}
\hline \multicolumn{6}{|c|}{ Groundwater Flow Rates $(V=\overline{\mathrm{K}} / \mathrm{\eta})$} \\
\hline \multirow{2}{*}{$\begin{array}{r}\overline{\text { AQUTTARD }} \\
\text { Water Table Interval }\end{array}$} & \multicolumn{2}{|c|}{$V(f / \bar{t} d)$} & $K \overline{(0 t / d)}$ & $I$ & 1 \\
\hline & $\begin{array}{l}\text { Min: } \\
\text { Max: }\end{array}$ & $\begin{array}{c}0.008 \\
34.8\end{array}$ & $\begin{array}{l}0.03 \\
3.25\end{array}$ & $\begin{array}{l}0.029 \\
0.047\end{array}$ & $\begin{array}{l}0.099 \\
0.0042\end{array}$ \\
\hline Shallow Bedrock Interval & $\begin{array}{l}\text { Min: } \\
\text { Max: }\end{array}$ & $\begin{array}{c}0.0002 \\
77.1\end{array}$ & $\begin{array}{l}0.0008 \\
0.6\end{array}$ & $\begin{array}{l}0.029 \\
0.047\end{array}$ & $\begin{array}{l}0.099 \\
0.00035\end{array}$ \\
\hline \multirow[t]{2}{*}{ AQUIFER } & \multicolumn{2}{|c|}{$\bar{V}(\mathrm{f} / \bar{d})$} & $\mathbf{K}(\mathrm{t} / \mathrm{d})$ & $I$ & $\eta$ \\
\hline & $\begin{array}{l}\text { Min: } \\
\text { Max: }\end{array}$ & $\begin{array}{r}2.71 \\
440.0\end{array}$ & $\begin{array}{l}22 \\
22\end{array}$ & $\begin{array}{l}0.007 \\
0.01\end{array}$ & $\begin{array}{l}0.0813 \\
0.0006\end{array}$ \\
\hline
\end{tabular}

\subsubsection{Chestnut Ridge}

Representative groundwater surface elevations throughout the Chestnut Ridge Regime were determined from depth to water measurements recorded for 77 monitoring wells (Appendix B, Table 15) during April 2007 (seasonally high flow conditions). Based on these data, regime-wide groundwater elevation isopleths were used to evaluate groundwater flow directions in the uppermost aquifer at the CRSP, CRSDB, KHQ, and ECRWP (Appendix A, Fig. 10). Note that the presampling groundwater elevations determined from the depth-to-water measurements recorded during the CY 2007 RCRA sampling events at each site were not used for this purpose. 
Isopleths of groundwater elevations in the Chestrut Ridge Regime stow steep hydraulic gradients down the northem flank of Chestnut Ridge (across geologic strike) near the CRSP. However, as noted in Sect. 3.4.3, the elongated shape of the VOC plume originating from this site and the erientation of the plume along the crest of the ridge indicate that the primary direction of groundwater flow (and contaminant transport) is from west to east (parallel with geologic strike). Seasonal groundwater elevations in monitoring wells at the CRSDB and ECRWP likewise indicate generally easterly flow, with components of flow to the north-northeast into BCV. Flow directions near KHQ are generally south toward Melton Hill Reservoir or southwest toward the unnamed tributary adjacent to the site. Horizontal hydraulic gradients determined from groundwater elevations in selected monitoring wells at each site are summarized below (Table 11).

Table 11. Representative horizontal hydroulic gradlents in the uppermost aquifer at the CRSP, CRSDB, KHQ, and ECRWP, April 2007

\begin{tabular}{|c|c|c|c|c|}
\hline \multicolumn{2}{|c|}{ Slte/Monltoring Well No. } & $\begin{array}{l}\text { Groundwater Elevation } \\
\text { (ft above msl) }\end{array}$ & $\begin{array}{c}\text { Lateral } \\
\text { Distance (ft) }\end{array}$ & $\begin{array}{c}\text { Horizontal } \\
\text { Hydraulic Cradient }(I)\end{array}$ \\
\hline $\begin{array}{l}\text { CRSP } \\
\text { Strike Normal: }\end{array}$ & $\begin{array}{l}G W-611 \\
G W-178 \\
G W-511\end{array}$ & $\begin{array}{r}944.73 \\
1052.16 \\
981.44\end{array}$ & $\begin{array}{l}394 \\
501\end{array}$ & $\begin{array}{l}0.273 \\
0.141\end{array}$ \\
\hline Strike Parallel: & $\begin{array}{l}\mathrm{GW}-178 \\
\mathrm{GW}-179 \\
\mathrm{GW}-609\end{array}$ & $\begin{array}{r}1052.16 \\
1011.97 \\
944.63\end{array}$ & $\begin{array}{c}762 \\
1528\end{array}$ & $\begin{array}{l}0.053 \\
0.044\end{array}$ \\
\hline CRSDB & $\begin{array}{l}\text { GW-159 } \\
\text { GW-156 }\end{array}$ & $\begin{array}{l}933.86 \\
906.23\end{array}$ & 542 & 0.051 \\
\hline KHQ & $\begin{array}{l}\text { GW-231 } \\
\text { GW-144 }\end{array}$ & $\begin{array}{l}835.14 \\
833.25\end{array}$ & 479 & 0.004 \\
\hline ECRWP & $\begin{array}{l}G W-292 \\
G W-298\end{array}$ & $\begin{array}{l}960.23 \\
939.28\end{array}$ & 711 & 0.039 \\
\hline
\end{tabular}

The modified Darcy equation described in Sect. 5.1.1 was used to calculate representative rates of groundwater flow within the uppermost aquifer (Knor Group) at the CRSP, CRSDB, ECRWP, and KHQ. Flow rate calculations are based on: (1) the range of hydraulic conductivity values $(0.0002$ to $13.8 \mathrm{ft} / \mathrm{d})$ indicated by results of straddle packer tests (Energy Systems 1988a) and falling-head permeability tests (Energy Systems 1997a); (2) effective porosity ranging from 0.0006 to 0.0813 (Energy Systems 1997b); and (3) the range of horizontal hydraulic gradients summarized above. Based on these input values and the inherent assumptions of the modified Darcy equation, calculated groundwater flow rates in the uppermost aquifer at each site, summerized below in Table 12 , range from $0.0009 \mathrm{ft}$ per year $(0.00001 \mathrm{f} / \mathrm{d})$ at $\mathrm{KHQ}$ to more than $1000 \mathrm{ft} / \mathrm{d}$ at the CRSP and the CRSDB. Calculated groundwater flow rates at the lower end of the range seem reasonable for diffuse flow across matrix intervals in the Knox Group. The upper values are within the range of flow rates typical of highly perneable conduits in karst terrains (Quinlan and Ewers 1985) and are generally supported by the flow rates (490 to $1250 \mathrm{f} / \mathrm{d}$ ) indicated by a dye-tracer study performed on Chestnut Ridge near ORNL (Energy Systems 1984). 
Table 12. Calculated rates of groundwater Dow in the uppermost aquifer at the CRSP, CRSDB, KHQ, and LCRWP

\begin{tabular}{|c|c|c|c|c|c|c|}
\hline \multicolumn{7}{|c|}{ Groundwater Flow Rates $(V=\mathrm{K} J / \eta)$} \\
\hline \multirow[t]{3}{*}{ CRSP } & \multirow[b]{2}{*}{ Strike-normal flow: } & \multicolumn{2}{|c|}{$V(\mathrm{ft} / \mathrm{d})$} & \multirow{2}{*}{$\begin{array}{c}\mathbf{K}(\mathrm{ft} / \mathrm{d}) \\
0.0002 \\
13.8\end{array}$} & \multirow{2}{*}{$\begin{array}{c}I \\
0.141 \\
0.273\end{array}$} & \multirow{2}{*}{$\begin{array}{c}\eta \\
0.0813 \\
0.0006\end{array}$} \\
\hline & & $\begin{array}{l}\text { Min: } \\
\text { Max: }\end{array}$ & $\begin{array}{l}0.0003 \\
6279\end{array}$ & & & \\
\hline & Strike-parallel flow: & $\begin{array}{l}\text { Mit: } \\
\text { Max: }\end{array}$ & $\begin{array}{l}0.00011 \\
1219\end{array}$ & $\begin{array}{c}0.0002 \\
13.8\end{array}$ & $\begin{array}{l}0.044 \\
0.053\end{array}$ & $\begin{array}{l}0.0813 \\
0.0006\end{array}$ \\
\hline CRSDB & & $\begin{array}{l}\text { Min } \\
\text { Max: }\end{array}$ & 1173 & $\begin{array}{l}0.0002 \\
13.8\end{array}$ & $\begin{array}{l}0.051 \\
0.051\end{array}$ & $\begin{array}{l}0.0813 \\
0.0006\end{array}$ \\
\hline KHQ & & $\begin{array}{l}\text { Min: } \\
\text { Max: }\end{array}$ & $\begin{array}{l}0.00001 \\
92\end{array}$ & $\begin{array}{r}0.0002 \\
13.8\end{array}$ & $\begin{array}{l}0.004 \\
0.004\end{array}$ & $\begin{array}{l}0.0813 \\
0.0006\end{array}$ \\
\hline ECRWP & & $\begin{array}{l}\text { Min: } \\
\text { Max: }\end{array}$ & $\begin{array}{c}0.0001 \\
897\end{array}$ & $\begin{array}{r}0.0002 \\
13.8\end{array}$ & $\begin{array}{l}0.039 \\
0.039\end{array}$ & $\begin{array}{l}0.0813 \\
0.0006\end{array}$ \\
\hline
\end{tabular}

\subsection{RCRA POINT-OP-COMPLIANCE MONITORING DATA}

The following subsections present evaluations of the CY 2007 RCRA post-closure corrective action monitoring results for the POC wells at the S-3 Site (GW-276), Oil Landfarm (GW-008), BCBG/WTP (GW-046), the Eastern S-3 Site Plame (GW-108), and the CRSP (GW-177). As required by site-specific conditions of the PCPs for the Bear Creek Regitre (Appendix B, Table 1), Upper East Fork Regime (Appendix B, Table 2), and Chestnut Ridge Regime (Appendix B, Table 3), each evaluation includes quantitative trend analysis of data for selected site-specifjc RCRA groundwater target contounds detected in the groundwater samples from the applicable POC well. Compounds selected for trend analysis are representative of the primary components of the groundwater contaminant plumes originating from each of these TSD units.

Concentration trends for the selected RCRA groundwater target compounds detected in each applicable POC well were determined from time-series plots of respective RCRA post-closure corrective action monitoring results obtained since January 1998, which coincides with the programmatic change from the conventional sampling method to the low-flow sampling method (see Sect. 4.2). The relative direction (upward or downward) of each concentration trend was determined by least-squares linear regression of the time-series data for each applicable RCRA groundwater target constituent. Non-detected results were excluded from the regression analyses, as were results that do not meet applicable DQOs (e.g., falsepositive VOC results).

\subsubsection{S-3 Site}

S-3 Site POC well GW-276 yields groundwater from the water table interval in the Nolichucky Shale approximately $200 \mathrm{ft}$ southeast of the S-3 Site (Appendix A, Fig. 14). Installed in July 1986, this well is constructed with nominal 4.5 in. diameter stainless steel riser casing and spiral-wound well screen (0.01 in. slot) and is completed with a monitored interval from 11.3 - 18.5 ft bgs (Appeadix B, Table 7). The well has a nearly continuous 21-year groundwater sampling history that includes quarterly RCRA interim status assessment monitoring (1986-1990; 1994) and semiannual RCRA post-closure corrective action monitoring (1995 present). Analytical results for these samples show that the well yields acidic (pH <6) calcium-magneșium-bicarbonate goumdwater containing several inorganic, organic, and 
radiological contaminants originating from the former S-3 Ponds, including nitrate, trace metals, alpha and beta radioactivity, and VOCs (see Sect. 3.4.1.1).

The S-3 Site RCRA groundwater target compounds listed below in Table 13 were detected in at least one of the groundwater samples collected from well GW-276 during CY 2007. Analytical results for the ful] suite of RCRA groundwater target compounds are in Appendix C. Aside from the false-posiljve results for acetone and methylene chloride (see Sect. 4.6), analytical results for the other RCRA groundwater target compounds meet applicable DQO criteria and are generally consistent with historical data for the well.

Table 13. CY 2007 sampling results for RCRA grondiwater target compouads detected in S-3 Site POC well GW-276

\begin{tabular}{|c|c|c|c|c|c|c|c|}
\hline $\begin{array}{c}\text { RCRA Groundwater Target } \\
\text { Compound }\end{array}$ & MCL & \multicolumn{3}{|c|}{ January 2007} & \multicolumn{3}{|c|}{ Juky 2007} \\
\hline Inorganles (mg/L) & & \multirow{6}{*}{\multicolumn{3}{|c|}{$\begin{array}{c}0.0794 \\
0.0099 \\
0.001024 \\
0.125 \\
19.4 \\
0.45\end{array}$}} & \multirow{6}{*}{\multicolumn{3}{|c|}{$\begin{array}{l}0.1 \\
0.0074 \\
. \\
0.102 \\
29.6 \\
0.21\end{array}$}} \\
\hline Barium & 2 & & & & & & \\
\hline Cadmium & 0.005 & & & & & & \\
\hline Mercury & 0.0004 & & & & & & \\
\hline Nickel & 0.1 & & & & & & \\
\hline $\begin{array}{r}\text { Nitrate (as N) } \\
\text { Utanium }\end{array}$ & 10 & & & & & & \\
\hline \multicolumn{8}{|l|}{ VOCs $(\mu \mathrm{g} / \mathrm{L})$} \\
\hline Acetoine & - & \multicolumn{3}{|c|}{ FP2 } & \\
\hline Methylene chloride & - & \multicolumn{3}{|c|}{ FP1 } & & & \\
\hline PCE & 5 & & 5 & & \multicolumn{3}{|c|}{$\begin{array}{l}\text { FP2 } \\
\text { A J }\end{array}$} \\
\hline \multicolumn{8}{|l|}{ Radfoanalytes ( $\mathrm{pCi} / \mathrm{L})$} \\
\hline Gross alpha activity & 15 & 120 & \pm & 20.6 & 109 & \pm & 19.1 \\
\hline Gross beta activity & $50^{n}$ & 151 & \pm & 24.9 & 218 & \pm & 35.5 \\
\hline Am-241 & - & & . & & 0.042 & $7 \pm$ & 0.0388 \\
\hline $\mathrm{Np}-237$ & - & 6.77 & $7 \pm$ & 2.72 & 4.6 & & 1.84 \\
\hline Total Radium & - & 1.24 & $4 \pm$ & 0.593 & 0.177 & \pm & 0.101 \\
\hline Sr-90 & - & 1.4 & \pm & 0.659 & 2.41 & \pm & 1,31 \\
\hline Tc-99 & $900^{*}$ & 233 & \pm & 38.5 & 282 & \pm & 46.1 \\
\hline $\mathrm{U}-234$ & - & 57.2 & \pm & 11 & 49.2 & \pm & 9.15 \\
\hline $\mathrm{U}-235$ & $=$ & 3.2 & \pm & 1.16 & 3.96 & \pm & 1.36 \\
\hline U-236 & . & 118 & \pm & 21.9 & 107 & \pm & 18.7 \\
\hline \multicolumn{2}{|c|}{ Presampling Groundwater Elevation } & \multicolumn{3}{|c|}{995.70} & \multicolumn{3}{|c|}{993.63} \\
\hline \multicolumn{8}{|l|}{$\mathrm{FP} 2=$ False } \\
\hline
\end{tabular}

Nitrate is the primary component of the groundwater contaminant plume originating from the former S-3 Ponds and, as shown in Table 13, is the principal inorganic RCRA groundwater target corapound detected at the bighest concentrations in the groundwater from well GW-276. Although both CY 2007 sampling results for nitrate exceed the drinking water MCL $(10 \mathrm{mg} / \mathrm{L})$, they reflect the substantial long. term concentration decrease illustrated by the time-series plot of the nitrate data (Appendix A, Fig. 17), with the concentrations evident in July $2006(18.6 \mathrm{mg} / \mathrm{L})$ and January $2007(19.4 \mathrm{mg} / \mathrm{L})$ being the lowest seported fot the well to date. The decreasing nitrate concentration trend is characterized by significant short-term (seasonal) fluctuations, with the peak concentrations evident in July 1998 (139 mg/L), 
July 2000 (105 $\mathrm{mg} / \mathrm{L})$, and July $2002(73.7 \mathrm{mg} / \mathrm{L})$ suggesting greater relative inflow of nitratecontarinated groundwater into the well during seasonally dry flow conditions.

As shown in Table 13, the groundwater samples collected from well $G W-276$ during CY 2007 contained several trace metals designated as RCRA groundwater target compounds for the $S-3$ Sitc, with concentrations of cadmium, nickel, and uranium exceeding their drinking water MCLs $(0,005 \mathrm{mg} / \mathrm{L}$, $0.1 \mathrm{mg} / \mathrm{L}$, and $0.03 \mathrm{mg} / \mathrm{L}$, respectively). These results are consistent with previous RCRA sampling data, although the concentrations are several orders of magnitude lower than the cadmium, nickel, and uranium levels indicated by historical data (e.g., $0.34 \mathrm{mg} / \mathrm{L}, 4.8 \mathrm{mg} / \mathrm{L}$, and $7.97 \mathrm{mg} / \mathrm{L}$, respectively, in October 1987). The time-series plot of the RCRA sampling results for uranium (Appendix A, Fig. 17), which shows a variable but clearly decreasing long-term trend $\left(\mathrm{R}^{2}=0.53\right)$ through July $2007(0.21 \mathrm{mg} / \mathrm{L})$, is representative of the concentration trends evident for the other trace metals. Interestingly, the substantial decrease in trace metal concentrations occurred with only a modest change in the acidic pH of the groundwater, as illustrated by the field $\mathrm{pH}$ measurements recorded during RCRA sampling events in October $1987(\mathrm{pH}=4.5)$ and July $2007(\mathrm{pH}=4.94)$. This suggest that the decreasing coneentrations of uranium and other trace metals are primarily attributable to stbstantially reduced advective flux of the metal ions via the groundwater flowpaths intercepted by the monitored interval in well GW-276.

Excluding the faIse-positive results for acetone and methylene chloride, PCE was the onIy VOC designated as a RCRA groundwater target compound for the S-3 Site that was detected in the groundwater samples collected from well GW-276 during CY 2007, with PCE concentrations at or below the $5 \mu \mathrm{g} / \mathrm{L}$ drinking water MCl (Table 13). These results are consistent with historical data and demonstrate, as noted is Sect 3.4.1.1, that VOCs are secondary components of the S-3 Site contaminant plume and have never been doninant compounds in the shallow groundwater from wejl GW-276. A timeseries plot of the PCE data (Appendix A, Fig. 17) shows variable concentrations dominaled by temporal peak levels evident in Juy $1999(14 \mu \mathrm{g} / \mathrm{L})$ and July $2000(14 \mu \mathrm{g} / \mathrm{L}$ ), with a decreasing linear regtession trend line $\left(\mathrm{R}^{2}=0.58\right.$ ). Also, none of the samples collected to date contained PCE degradation products (e.g., TCE and cl2DCE), which suggests that the reduced PCE concentrations indicated by the more recent sampling results are not attributable to biologically-mediated degradation in the groundwater.

Each radjological analyte designated as a RCRA groundwater target compound was detected (i.e., $>$ MDA and TPU) in one or both groundwater samples collected from well GW-276 in CY 2007. Results for cach radiological analyte except Am-241 are consistent with historical data; the July 2007 sanmling result for Am-241 (0.0427 pCi/L) just slightly exceeds the MDA $(0.0232 \mathrm{pCi} / \mathrm{L})$ and is a likely anaiytical artifact. In any case, poss alpha activity in the shallow groundwater from this well remains substantially above the MCL ( $15 \mathrm{pCi} / \mathrm{L}$ ), with $\mathrm{U}-234$ and $\mathrm{U}-238$ being the primary alpha-emitting radionuclides (Table I3). Gross beta activity in the groundwater likewise remains above the SDWA screening level $(50 \mathrm{pCi} / \mathrm{L})$ for a 4 millirem per year (mom/yr) dose equivalent (the MCL for beta activity). The principal beta-particle emitting radionuclide within the S-3 Site contaminant plume is Tc-99, although both groundwater samples collected from well GW-276 in CY 2007 had Tc-99 concentrations below the SDWA threshold value ( $900 \mathrm{pCi} / \mathrm{L}$ ) for a $4 \mathrm{mren} / \mathrm{yr}$ dose equivalent from Tc- 99 (Table 13). Moreover, a time-series plot of the Tc-99 data for well GW-276 shows a clearly decreasing concentration trend $\left(R^{2}=0.82\right)$ that generally mirrors the nitrate trend (Appendix A, Fig. 17).

The CY 2007 RCRA groundwater sampling results for well GW-276 generally continue the decreasing long-tertn concentrations trends evident for the representative components of the contaminant plume originating from the S-3 Site (nitrate, uranium, PCE, and Tc-99). These results are consistent with the conceptual model for contaminant migration from the S-3 Site, whereby contarninant concentrations are expected to decrease over time because of: (1) substantially reduced contaminant flux following cessation of waste disposal at the site and the subsequent installation of the low-permeability cap; (2) the 
cumulative effects of various natural attenuation processes, including discharge of contaminated groundwater from the Aquitard into the Bear Creek tributary drainage system; and (3) the continued westward migration (parallel with geologic strike) of the center of mass of the contaminant plume originating from the former S-3 Ponds (DOE 1997).

\subsubsection{Oil Landfarm}

Oil Landfarm POC well GW-O08 yields groundwater from the water table interval in the Nolichucky Shale directly south of the approximate mid-point of the Oil Landfarm HWDU (Appendix A, Fig. 14). Installed in September 1983, this well is constructed with nominal 2 in. diameter stainless steel riser casing and spiral-wound well screen (0.01 in. slot) and is completed with a monitored interval from 13 to $25.5 \mathrm{ft}$ bgs (Appendix B, Table 7). The well has an intermittent goundwater sampling history initiated by pre-RCRA characterization manitoring (1983-1985), with a subsequent prolonged sampling gap (1986-1997) followed by nearly ten years of semianulal sampling for RCRA post-closure corrective action monitoring (1998-present). Analytical results for these samples show that the well yields acidic $(\mathrm{pH}<5.5)$ calcium-magnesium bicatbonate groundwater distinguished by unusually low $(<10 \mathrm{mg} / \mathrm{L}$ ) total dissolved solids (TDS), which implies short groundwater residence time and suggests that the well intercepts hydraulically active flowpaths. Groundwater from the well contains a mixture of dissolved VOCs, primarily chlorinated hydrocarbons dominated by PCE, that are believed to originate from the southern landfanm plots at the site (see discussion in Sect. 3.4.1.2).

The RCRA groundwater target constituents for the Oil Landfarm listed below in Table 14 were detected in at least one of the groundwater samples collected from well GW-008 during CY 2007. Respective analytical results for these constituents meet applicalble DQO criteria and are generally consistent with previous RCRA post-closure groundwater monitoring results for the well.

Table 14. CY 2007 sampling resolts for RCRA gronndwater target compounts detected in OA Landfarm POC welt GW-008

\begin{tabular}{|c|c|c|c|}
\hline $\begin{array}{l}\text { RCRA Groundwater Target } \\
\text { Compound }\end{array}$ & MCL & January 2007 & July 2007 \\
\hline Inorganims $(\mathrm{mg} / \mathrm{L})$ & 2 & 0.093 & 0.121 \\
\hline $\begin{array}{r}\text { PCE } \\
T C E \\
\text { CI2DCE } \\
\text { I1DCE }\end{array}$ & $\begin{array}{r}5 \\
5 \\
70 \\
7 \\
\end{array}$ & $\begin{array}{r}40 \\
9 \\
21 \\
6\end{array}$ & $\begin{array}{r}73 \\
11 \\
23 \\
4 \\
\end{array}$ \\
\hline PresampIIng Groundwa & $\begin{array}{l}\text { Elevatiou } \\
\text { bove misl) }\end{array}$ & 950.97 & 948.83 \\
\hline
\end{tabular}

Barium is the only inorganic RCRA groundwater target constituent detected in either groundwater stample collected from well GW-008 during CY 2007 (Table 14). These results show that barium concentrations remain within the range of background levels in the Bear Creek Regime and at least an order of magnitude below the drinking water MCL.

As shown in Table 14, PCE, TCE, c12DCE, and 11DCE were detected in both groundwater sanples collected from well GW-008 during CY 2007. As in previous years, PCE was the dominant VOC detected in each sample, the concentrations being at least two times higher than the concentrations reported for TCE, 11DCE, and c12DCE. These RCRA sampling results aiso show that the concentrations 
of PCE and TCE remain above their drinking water MCLs ( $5 \mu \mathrm{g} / \mathrm{L}$ for both), with 11DCE concentrations being slightly below the MCL $(7 \mathrm{Hg} / \mathrm{L})$, and the c12DCE concentrations being substantially below the MCL $(70 \mu \mathrm{g} / \mathrm{L})$. The dominanee of PCE in the shallow groundwater from well GW 008 suggests that this compound was probably a principal conponent of the associated wastes disposed at the Oil Landfarm. Additionally, the suite of VOCs present in the groundwater reflects the complex composition of the dissolved VOC plume originating from the landfarm plots at the site (see Sect. 2.1.2). Anatrobic conditions (i.e., dissolved oxygen $<0.5 \mathrm{ppm}$ ) in the subsurface nearest the source areas are conducive to biologically-mediated sequential degradation (reductive dechlonination) of PCE and its daughter products (TCE, TCE, DCE isomers, and VC), which intermingle in the groundwater and migrate hydraulically downgradient, ultimately encountering aerobic conditions where $\mathrm{PCE}$ and TCE will not biodegrade (Weidemeier et al. 1999). Aerobic conditions seen to ptevail in the groundwater from the well GW-008, as indicated by pre-sampling field measurements that typically show dissolved oxygen above 1 ppm (e.g., $1.21 \mathrm{ppm}$ in January and July 2007).

The PCE concentrations indicated by the RCRA sampling results from January 2007 ( $40 \mu \mathrm{g} / \mathrm{L}$ ) and July $2007(73 \mu \mathrm{g} L)$ illustrate the substantial short-term concentration fluctuations that dominate the timeseries plot of the PCE results for well GW-008 (Appendix A, Fig. 18). Additionally, the linear regression trend line $\left(R^{2}=0.15\right.$ ) is skewed upward by the relatively low PCE concentrations (e.g., $7 \mu \mathrm{g} L$ in July 1999) evident before a strarp increase in January $2000(75 \mu \mathrm{g} / \mathrm{L})$ and the subsequent indeterminate (not clearly increasing or deceasing) concentration trend through July 2007 . It is not clear from the RCRA sampling results what may have caused the sharply higher PCE levels or why the concentrations exhibit such wide short-term fluctuations. However, there appears to be some correlation between PCE levels and groundwater flow conditions because each of the temporal peak concentrations indicated by the PCE results obtained after January 2000 were reported for seasonally dry RCRA groundwater sarming events in July 2001, July 2002, July 2003, July 2005 , and July 2007 (Appendix A, Fig. 18). These findings suggest that the seasonal (or episodic) recharge may ptomote greater relative inflow of less PCEcontaminated groundwater into the well.

The TCE concentrations indicated by the RCRA groundwater sampling results from January 2007 $(9 \mu \mathrm{g} / \mathrm{L})$ and July 2007 (11 $\mu \mathrm{g} / \mathrm{L})$ continue a fairly indeterminate concentration trend evident since January $2000(12 \mu \mathrm{g} / \mathrm{L})$, when the TCE levels initially increased above the conspicuousty lower levels indicated by previous RCRA sampling results for well $\mathrm{GW}-008$ (e.g, $4 \mu \mathrm{g} / \mathrm{L}$ in July 1998). The lower TCE concentrations evident before January 2000, like the corresponding PCE results noted above, seem to skew the linear regression trend line $\left(\mathrm{R}^{2}=0.35\right)$ upward, as shown on the time-series plot of the TCE data (Appendix A, Fig. 18). Unlike PCE, however, the TCE concentrations evident after January 2000 exhibit clearly cyclic fuctuations, with temporal peak concentrations indicated by the TCE results from seasonally wet RCRA groundwater sampling events in January 2001, January 2002, January 2004, January 2005, and January 2006 (Appendix A, Fig. 18). This relationship suggests that seasonal (ot episodic) recharge promotes greater relative inflow of TCE-contaninated groundwater itoto the well.

The CY 2007 RCRA groundwater sampling tesults show that c1 2DCE is the dominant DCE isomer in the groundwater from well GW-008, with concentrations nearly four times higher than those of IIDCE (Table 14). These results also show that the c12DCE concentrations remain bigher than the levels of TCE, possibly because anacrobic biodegradation of DCE isomers occurs at a substantially slower rate than that of TCE (and PCE), and the REDOX conditions near the source area(s) may not be sufficiently reducing to degrade $\mathrm{C} 12 \mathrm{DCE}$ to VC (Wejdemeier et al. 1999). However, unlike both PCE and TCE, the linear regression trend line $\left(R^{2}=0,47\right)$ shown on the time-series plot of the c I2DCE results does not appear to be skewed upward by the concentrations evident before January 2000 (Appendix A, Fig. 18), which suggests that the trend reflects a general increase in the relative flux of c12DCE. Also, the c12DCE results obtained after January 2000 show cyclic concentration fluctuations similar to (and often 
concurtent with) those evident for TCE, with four of the five temporal peak cl2DCE concentrations reported for seasonally wet RCRA groundwater sampling events in January 2001, January 2004, January 2005, and January 2006 (Appendix A, Fig. 18). This telationship suggests that seasonal (or episodic) recharge promotes greater telative inflow of c12DCE-contaminated groundwater into the well.

It is not clear from the RCRA groundwater sampling results obtained to date if the above-noted concentration trends for PCE, TCE, and c12DCE are significant with respect to the overall flux of dissolved VOXs via the groundwater flowpaths miterepted by the monitored interval in well GW-008. Nevertheless, the concentrations of these VOCs are significantly lower than the summed levels $(700 \mu \mathrm{g} / \mathrm{L}$ ) indicated by the pre-RCRA sampling results for the well (Energy Systems 1990). The lower levels of dissolved VOCs now evident in the groundwater from the well are primarily attributable to the closure and capping of the Oil Landfarm, which substantially reduced the flux of dissolved VOCs in the shallow groundwater, and the continued discharge of VOC-contaninated groundwater from the stallow flow system in the Aquitard into the Bear Creck tributary drainage system (DOE 1997). The reduced concentrations also reflect the cumblative effects of natural attenuation processes active within the VOC plume, including biologically-mediated reductive dechlorination in anaerobic zones near the source areas, and advection, dispersion, and sorption in aerobic zones within the VOC plume in the groundwater downgradient of the Oil Landfarm.

\subsubsection{Bear Creek Burial Grounds/Walk-In Pits}

POC well GW-046 at the BCBG/WIP yields groundwater from the water table interval in the Nolichucky Shale near the southwest comer of BG-A South (Appendix A, Fig. 14). Installed in October 1983, this well is constructed with nominal 2 in, diameter stainless steel riser casing and spiralwound well screen (0.01 in. slot) and is completed with a monitored interval from 5 to $20.3 \mathrm{ft}$ bgs (Appendix B, Table 7). The groundwater sampling history for the well includes pre-RCRA characterization monitoring (1983-1985), quarterly RCRA interim status assessment motitoting (1987-1990; 1995), and semiannual RCRA post-closure corrective action monitoring (1998-present). Analytical results for the samples collected to date show that the well yields acidic ( $\mathrm{pH}<6$ ) calciummagnesium bicarbonate groundwater distinguished by enriched levels of chlotide ( $40 \%$ of total anions). Groundwater from the well contains a mixture of dissolved VOCs, including petroleum products and chlorinated hydrocarbons, with the extremely high concentrations $(>1000 \mu \mathrm{g} / \mathrm{L}$ ) of several compounds (e.g., PCE and c12DCE) attributable to the presence of DNAPLs in the Nolichucky Shale dowtr-dip (south) of BG-A South (see Sect. 3.4.1.3).

The VoCs listed below in Table 15 are the only RCRA groundwater target compounds for the $\mathrm{BCBG/WIP}$ that were detected in either of the groundwater samples collected from well GW-046 during CX 2007. Analytical results for each of these VOCs meet applicable DQO criteria, are generally consistent with previous RCRA sampling results for the well, and show that the concentrations of PCE, TCE, c12DCE, 11DCE, and VC remain substantially above respective drinking water MCLs. Benzene concentrations are significantly lower than those of the chlorinated hydrocarbons, but nonetheless exceed the MCL, whereas 111TCA concentrations are substantially below the MCL. 
Takje 15. CY 2007 monltoring results for RCRA groundwater target compounds detected in BCBG/WIP POC well GW-1046

\begin{tabular}{|c|c|c|c|}
\hline $\begin{array}{l}\text { RCRA Groundwater Target } \\
\text { Compound }\end{array}$ & MCL & January 2007 & July 2007 \\
\hline \multicolumn{4}{|l|}{ Organdes $(\mu \mathrm{g} / \mathrm{L})$} \\
\hline Benzene & 5 & 9 & 9 \\
\hline PCE & 5 & 370 & 420 \\
\hline TCE & 5 & 730 & 620 \\
\hline C12DCE & 70 & 2500 & 1700 \\
\hline 11DCE & 7 & 46 & 27 \\
\hline $\mathrm{VC}$ & 2 & 240 & 170 \\
\hline $111 \mathrm{TCA}$ & 200 & 33 & 19 \\
\hline 11DCA & - & 95 & 70 \\
\hline \multicolumn{2}{|c|}{$\begin{array}{r}\text { Presampilng Groundwater Elevatton } \\
\text { (ft above insl) }\end{array}$} & 917.15 & 915.65 \\
\hline
\end{tabular}

Several of the VOCs in the shallow groundwater from well GW-046 (e.g-, benzene, PCE, and 111TCA) are probably principal components of the associated wastes disposed in the BCBG/WT, whereas the other VOCs (e.g, c12DCA and 11DCA) are present because of the chemical and/or biological degradation of the related parent compounds. Biodegradation (sequential reductive dechlorination) of PCE and its daughter products also may account for the characteristically high levels of chloride in the shallow groundwater from the welt (e.g., $37.8 \mathrm{mg} / \mathrm{L}$ in July 2004). Biodegradation most likely occurs under the anacrobic conditions in the subsurface nearest the source areas (including DNAPL) at the BCBGNWP, with the relatively high concentrations of VC in well GW-046 indicating that REDOX conditions near the source areas are sufficiently reducing to degrade DCE isomers. As noted in Scet 5.2.2, PCE biodegrades more rapidly than c $12 D C E$, which may explain why the c12DCE concentrations remain substantially higher than the PCE levels. Also, abiotic (chemical) processes may degrade 111TCA to acetic acid under either aerobic or anaerobic conditions (McCarty 1996), which may account for the acidic $\mathrm{pH}$ of the groundwater samples from well GW-046 (e.g., 5.37 in July 2007) and the significantly higher levels of 11DCA relative to 111TCA. The following discussion presents an evaluation of the concentration trends for selected parent compounds (benzene, PCE, and 111TCA) and degradation products (c12DCE and 11DCA) that are representative components of the dissolved piume of VOCs in the shallow groundwater downgradient of the BCBG/WIP.

Equal concentrations of benzene ( $9 \mathrm{Hg} / \mathrm{L}$ ) detected in the groumdwater samples collected from well GW-046 during CY 2007 continue the generally indeterminate long-term concentration trend reflected by the flat linear regression trend line $\left(\mathrm{R}^{2}=0.01\right)$ shown on the time-series plot of the RCRA groundwater sampling results for benzene (Appendix A, Fig. 19). These results show decreasing benzene concentrations between July $1998(49 \mu \mathrm{g} / \mathrm{L})$ and July $2002(9 \mu \mathrm{g} / \mathrm{L})$, with successive sharp concentration increases in January $2003(47 \mu \mathrm{g} / \mathrm{L})$ and July $2003(240 \mu \mathrm{g} / \mathrm{L})$, followed by another decreasing trend through July $2007(9 \mu \mathrm{g} / \mathrm{L})$. The distinetive temporal peak concentration of benzene in July 2003, which substantially exceeds the previous maximum concentration $(49 \mu \mathrm{g} / \mathrm{L}$ in July 1998), potentially reflects a corresponding "surge" in the relative flux of benzene in response to local recharge from nearly 3 in. of rainfall (as measured at a rain gauge in $\mathrm{BCV}$ ) during the five days preceding the July 2003 groundwater sampling date. Subsequent natural attenuation appears to have gradually dissipated the increased mass of benzene associated with the "surge" such that the benzene concentrations appear to have returned to the lower, fairly asymptotic levels evident before July 2003 (Appendix A, Fig. 19). 
Widely flucluating long-term concentration trends are indicated by the time-serics plots of the RCRA groundwater sampling resuIts for PCE and c12DCE in well GW-046, with the linear regression of the respective data showing a slightly decreasing trend line $\left(R^{2}=0.09\right)$ for PCE paralleled by the trend line for c12DCE $\left(\mathrm{R}^{2}=0.13\right.$ ) (Appendix A, Fig. 19). Short-term fluctuations in the concentrations of both compounds frequently coincide and often correlate with seasonally dry groundwater flow conditions, as illustrated by the concurrent peak levejs of PCE and c12DCE indicated by sampling results from July $1998(4600 \mu \mathrm{g} / \mathrm{L}$ and $6417 \mu \mathrm{g} / \mathrm{L})$, July $2000(8400 \mu \mathrm{g} / \mathrm{L}$ and $11,260 \mu \mathrm{g} / \mathrm{L})$, and July 2003 $(5100 \mu \mathrm{g} / \mathrm{L}$ and $7200 \mathrm{\mu g} / \mathrm{L})$. Respective peak concentrations of PCE and c12DCE evident in July 2003 , like the peak benzene concentration noted above, also presumably reflect a recharge-related flux increase in response to the pre-sampling rainfall. Previous termporal high concentrations of PCE and c12DCE evident in July 1998 and July 2000 likewise may reflect episodic recharge-related increases in contaminant flux, although the corresponding sampling results for benzene do not show temporal peak concentrations for either sampling event (Appendix A, Fig. 19).

Times-series plots of the RCRA groundwater sampling results for 111TCA and 11DCA in well GW-046 show a widely fluctuating long-term concentration trend for 111TCA that is similar to those than evident for PCE and a 12DCE, with linear regression of the 11JTCA data likewise showing a decreasing trend line $\left(R^{2}=0.176\right)$, whereas the data for 11DCA exhibit much less temporal variability and define a flat or slightly increasing linear regression trend line $\left(R^{2}=0.003\right.$ ) (Appendix A, Fig. 19). Although 111TCA and 1 IDCA concentrations both "spiked" in July 2003 in response to the recharge-related flux increase noted above, the previous and subsequent RCRA sampling results show temporal peak concentrations that are much more pronounced for 111TCA. Also, unlike the PCE and 1 12DCE levels, samples collected during seasonally high groundwater flow conditions often contain the highest concentrations of 111TCA, as illustrated by the peak 11 1TCA levels evident in January $2000(300 \mu g / L)$, January $2001(260 \mu g / L)$, and January $2006(95 \mu \mathrm{g} / \mathrm{L})$. This relationship suggests that the groundwater flowpaths intereepted by the monitored interval in the well allow greater relative inflow of 111TCA-contaminated groundwater into the well during seasonatly (and episodically) high flow conditions.

The CY 2007 RCRA groundwater sampling data for well GW-046, as indicated by the preceding evaluation of long-term concentration trends for selected VOCs (parent compounds and associated degradation products), are generaily consistent with the conceptual model for contaminant transport from sources at the BCBG/WIP, whereby VOC concentrations in the shallow groundwater are expected to slowly decrease in response to the reduced flux of VOCs following the closure and capping of the waste disposal areas, and from the combined cumulative effects of various natural attenuation processes (DOE 1997). Also, the DNAPL in the subsurface at the site, if undisturbed, will remain a long-term source of dissolved VOCs (parent compounds and related degradation products) in the deeper groundwater. Driven by the upward hydraulic gradients typical of the Aquitard fortnations in BCV west of Y-12, VOCs dissolved from the DNAPL ultimately may enter the shallow flow system and discharge into the Bear Creek draingge system (DOE 1997).

\section{2,4 Eastern S-3 Site Plume}

Eastem \$-3 Site Plume POC well GW-108 yields goundwater from the shallow bedrock interval in the Nolichucky Shale approximately $800 \mathrm{ft}$ southeast of the S-3 Site (Appendix A, Fig. 15). Installed in September 1984, the well is constructed of nominal 4 in. diameter polyvinyl chloride (PVC) riser casing and well screen (0.01 in. slot) and completed with a monitored interval from 41 to $58.6 \mathrm{ft}$ bgs (Appendix B, Table 7). This well has an extensive sampling history that includes quarterly RCRA interim-status assessment monitoring (January 1986-January 1990) and semiannual RCRA postclosure corrective action monitoring (June 1995-present). Historical sampling results show that this well 
yields acidic goundwatet ( $\mathrm{pH}<6$ ) characterized by very high levels of nitrate $(>10,000 \mathrm{mg} / \mathrm{L}$ ), calcium $(>10,000 \mathrm{mg} / \mathrm{L})$, magnesium $(>900 \mathrm{mg} / \mathrm{L})$, sodium $(>400 \mathrm{mg} / \mathrm{L})$, and barium $(>90 \mathrm{mg} / \mathrm{L}) ;$ a mixture of dissolved VOCs (primatily acetone, chloroform, and methylene chloride) with summed concentrations typically below $100 \mu \mathrm{g} / \mathrm{L}$; very high beta radioactivity $(>10,000 \mathrm{pCi} \mathrm{L})$, which is primarily from Te-99; and elevated alpha radioactivity ( $>15 \mathrm{pCi} / \mathrm{L}$ ), which is primarily from uranium isotopes. These RCRA groundwater sampling results are believed to be repregentative of contaminant concentrations within strike-parallel groundwater transport/migration pathways in the Nolichucky Shale to the east of the former S-3 Ponds (DOE 1998).

The RCRA groundwater target constituents listed below in Table 16 wete detected in the groundwater samples collected from POC well GW-108 during CY 2007. Analytical results for each constituent except acetone meet applicable DQOs (both results for acetone are false positives as noted in Sect. 4.6) and are consistent with historical data for the well.

Table 16. CV 2007 sampiling results for RCRA groundwater target compounds detected in Esastern S-3 Site Pume POC well GW-10:

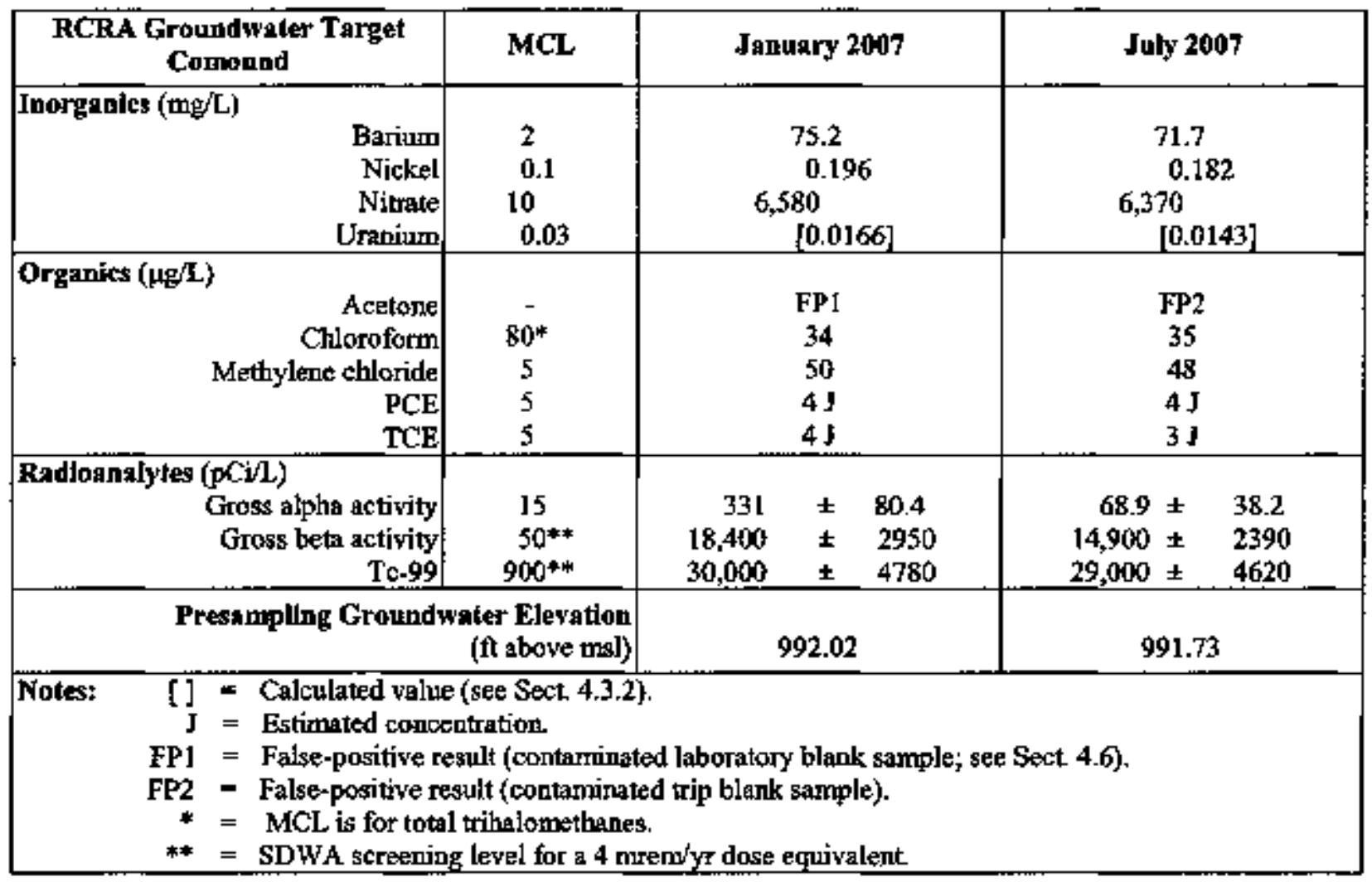

Nitrate is the primary component of the groundwater contaminant plume originating from the former S-3 Ponds and, as shown in Table 16, the CY 2007 RCRA sampling results indicate that nitrate concentrations in the shallow groundwater from well GW-108 remain two orders of magnitude above the drinking water MCL (10 mgL). Nevertheless, these nitrate results continue a clearly decreasing longterm concentration trend illustrated by the time-series plot of the nitrate data (Appendix A, Fig. 20), with the concentration evident in July $2007(6370 \mathrm{mg} / \mathrm{L})$ being the lowest reported for the well to date. Tempotal peak nitrate concentrations in February $1999(11,800 \mathrm{mg} / \mathrm{L})$, July $2000(13,300 \mathrm{mg} / \mathrm{L})$, and Jamuary $2003(10,400 \mathrm{mg} / \mathrm{L})$ dominate the decreasing trend, but most of the RCRA sampling results for 
nitrate, including the CY 2007 data, indicate fairly modest short-term concentration fluctuations. Also, the temporal changes in the nitrate concentrations do not exhibit any consistent relationship with seasonally wet or dry flow conditions. Moreover, the minimal seasonal water-table fluctuations incticated by the RCRA presampling groundwater elevations in the well (see Sect. 4.3.2), as illustrated by the $0.29 \mathrm{ft}$ difference between groundwater elevations in January and July 2007 (Table 16), do not support substantial flow-related variations in the advective flux of nitrate (and other similarly mobile contaminants) via the flowpaths intercepted by the monitored interval in well GW-108.

As shown in Table 16, the groundwater samples collected from well GW-108 during CY 2007 contained three trace metals designated as RCRA groundwater target compounds for the Eastem \$-3 Site Plume: (1) barium coneentrations an order of magnitude above the MCL (1 mg/L); (2) nickel concentrations slightly above the drinking water MCL $(0.1 \mathrm{mg} / \mathrm{L}$ ); and (3) (calculated) uranium concentrations slightly below the MCL (0.03 $\mathrm{mg} / \mathrm{L}$ ). These results illustrate the heterogeneous distribution of trace metals in the acidic groundwater within the Eastem S-3 Site Plume.

Excluding false-positive results (acetone, see Sect. 4.6), chlorofom, methylene chloride, PCE, and TCE are the VOCs designated as RCRA goundwater target constituents for the Eastern S-3 Site Plune that were detected in the groundwater samples collected from well GW-108 during CY 2007 (Table 16). These results are consistent with previous RCRA sampling data and show that the dominant VOCs in the groundwater are methylene chloride and chlorofom. Methylene chloride was detected at the highest concentrations that substantially exceed the drinking water MCL $(5 \mu \mathrm{g} / \mathrm{L})$. Chloroform was detected at comparable but lower concentrations that continue a widely variable but generally increasing $\left(R^{2}=0.16\right)$ long-term concentration trend (Appendix A, Fig. 20). In contrast, both PCE and TCE were detected at much lower levels that remain below the respective MCL for each compound ( $5 \mu \mathrm{g} / \mathrm{L}$ ), and respective results continue the indeterminate long-term concentration trends illustrated by the TCE results from RCRA groundwater sampling in March $1998(3 \mu \mathrm{g} / \mathrm{L})$, July $200 \mathrm{l}(3 \mu \mathrm{g} / \mathrm{L})$, Januaty $2004(4 \mu \mathrm{g} / \mathrm{L})$, and July $2007(4 \mu \mathrm{g} / \mathrm{L})$. It is not clear from the available data if such divergent concentration trends are significant with respect to the relative flux of VOCs via the groundwater flowpaths intetcepted by the monitored interval in the well.

Gross alpha activity reported for the groundwater samples in January 2007 (331 $\mathrm{pCi} / \mathrm{L}$ ) and July $2007(68.9 \mathrm{pCi} / \mathrm{L})$ show that the levels of alpha radioactivity in the shallow groundwater from well GW-108 remain substantialiy above the drinking water MCL ( $5 \mathrm{pCiL}$ ). These results also illustrate the significant short-term variability indicated by previous RCRA sampling results for gross alpha activity, which include a suspected outlier result $(1334 \mathrm{pCi} / \mathrm{L})$ from January 2003 . The apparent temporal variability may be an artifact of the analytical interference associated with the very high levels of TOS in the (unfiltered) groundwater samples from this well. Also, gross alpha activity was detected (i.e., $>$ MDA and TPU) in only two of the ten samples collected from the well between June 1995 and July 2000, but was detected in all but two of the 14 samples subsequently collected through July 2007 . This suggests perhaps more accurate measurement of gross alpha activity rather than a potential overall increase in the flux of alpha-emitting radionuclides via the groundwater flowpaths intercepted by the monitored interval in well GW-108.

As shown in Table 16, both of the groundwater samples collected from well GW-108 during CY 2007 contained very high levels of gross beta activity and Tc-99, a beta-emitting radionuclide that is a principal component of the Eastern S-3 Ponds Plume (see Sect. 3.4.2). These results, which do not appear to be significantly effected by the high TDS of the groundwater samples, show that both gross beta activity and Tc-99 activity remain multjple orders of magnitude above the respective SDWA threshold levels (50 pCi/L and $900 \mathrm{pCi} / \mathrm{L}$, respectively) for a $4 \mathrm{mrem} / \mathrm{yr}$ dose equivalent (the drinking water MCL for 
goss beta activity). A time-series plot of the Tc-99 results shows a clearly increasing long-term concentration trend (Appendix A, Fig. 20), strongly supported by the linear regression trend line $\left(\mathrm{R}^{2}=0.66\right)$. However, the CY $2007 \mathrm{RCRA}$ sampling results indicate that the Tc-99 levels have decreased from the historical peak evident in July $2006(33,900 \mathrm{pCi} / \mathrm{L})$. Considering the mobility of Tc-99 in the groundwatcr, the increased levels of Tc-99 may reflect a corresponding increase in the relative flux of Te-99 in the shallow groundwater flow system east of the former S-3 Ponds. The increased levels (flux) of Tc-99 contrasts with the concurrently decreasing leveis (flux) of nitrate, which seerns umusual considering that both contaminants share a common source (the former S-3 Ponds) and are chemically stable and highly mobile in the groundwater. Such divergent concentration trends probably reflect the complex hydrochemical dynamics within the Eastem S-3 Site Plume. For example, Tc-99 levels in the groundwater may not be influenced by attenuation processes that work to reduce the concentrations of nitrate.

Under the conceptual groundwater flow and contaminant transport models presented in the CERCLA RI for the UEFPC CA (DOE 1998), the concentrations of contaminants in the shallow groundwater east of the S-3 Site are expected to docrease at various rates in response to the substantially reduced contaninant Jlux after the former S-3 Ponds were closed and capped; the continued eastward (strike-paralle) migration of the center of mass of the Eastern S-3 Site Plume; differential retardation and natural attenuation in the subsurface; and discharge of contaminated groundwater into the subsurface drainage systern that replaced the headwaters of UEFPC (DOE 1998). The decreasing nitrate concentration trend continued by the CY 2007 RCRA post-closure groundwater monitoring results for well GW-108 is consistent with the conceptual flow/transport model. However, the increasing trend for Tc-99 suggests a corresponding increase in the relative flux of Tc-99 and does not conform to the model.

\subsubsection{Chestnut Ridge Securlty Pits}

The CRSP POC well GW-177 yields groundwater from the Knox Group (Copper Ridge Dolomite) at the western end of the former waste disposal trenches at the site (Appendix A, Fig. 16). Fnstalled in October 1985, this well is constructed of nominal 4 in. diameter PVC riser casing and well screen (0.01 in. slot) and is completed with a monitored interval from 130 to $145 \mathrm{ft}$ bgs (Appendix B, Table 7). The well has an extensive groundwater sampling history that includes quarterly RCRA interim status assessment monitoring (Febnuary 1986-February 1996), which spanmed the closure of the CRSP and the installation of the low-penneability cap at the site, and semiannual RCRA post-closure corrective action monitoring (July 2001-present). Analytical results for these samples show that the well yields calciummagnesium-bicarbonate groundwater containing a mixture of dissolved VOCs. As noted in Sect. 3.4.3, the presence of these VOCs in the groundwater at this well reflects their strike-parallel groundwater transport (or possibly vapor-phase transport) toward a localized depression in the water table located to the west of the westem disposal trenches at the CRSP.

The RCRA groundwater target compounds listed below in Table 17 were detected in the groundwater samples collected from well GW-177 during CY 2007. All of these results meet applicable DQOs, are consistent with previous RCRA groundwater sampling results for the welt, and show background levels of cadmium, chromium, nickel, and gross alpha activity along with modest levels of VOCs dominated by 11DCA. 
Table 17. CY 2007 sampilug results for RCRA groundwater target compounds detected in CRSP POC Well GW-177

\begin{tabular}{|c|c|c|c|}
\hline $\begin{array}{l}\text { RCRA Groundwater Target } \\
\text { Componnd }\end{array}$ & MCL & January 2007 & July 2007 \\
\hline Inorganics (mg/t) & $\begin{array}{l}0.005 \\
0.1 \\
0.1 \\
\end{array}$ & $\begin{array}{l}0.0127 \\
0.0113\end{array}$ & $\begin{array}{l}0.0002 \\
0.0194 \\
0.0134\end{array}$ \\
\hline $\begin{array}{r}11 \mathrm{DCA} \\
11 \mathrm{DCE} \\
111 \mathrm{TCA}\end{array}$ & $\begin{array}{r}7 \\
200\end{array}$ & $\begin{array}{c}26 \\
5 \\
8\end{array}$ & $\begin{array}{c}25 \\
6 \\
7\end{array}$ \\
\hline $\begin{array}{c}\text { Radioanalytes (pCi/L) } \\
\text { Gross alpha activity }\end{array}$ & 15 & . & $2.73 \pm 1.56$ \\
\hline Presampling Groundw' & $\begin{array}{l}\text { r Elevation } \\
\text { above asl) }\end{array}$ & 1038.78 & 1039.01 \\
\hline
\end{tabular}

As shown in Table 17, the CY 2007 RCRA sampling results for well GW-177 show the highest concentrations for 11DCA with Jower concentrations of 11DCE and 111TCA that are below respective drinking water MCLs of $7 \mu \mathrm{g} / \mathrm{L}$ and $200 \mu \mathrm{g} / \mathrm{L}$. These compounds are confirmed components of the dissolved VOC plume originating from the westem waste disposal trenches at the CRSP. Most likely, 111TCA was a component of the associated wastes and is probably the parent of IIDCA, which is an intermediate degradation product along with IIDCE. Indeed, degradation of the IllTCA most likely explains the abserved change over time in the ratio between the concentrations of 11DCA and 111TCA (11DCA:111TCA), which steadily increased over time from near 0.25:1 in the late 1980s to more than 3:1 since January 2006 (Appendix A, Fig. 21). Additionally, 111TCA may degrade at a faster rate than either 11DCE or 11DCA (Weidemejer et al. 1999), which potentially accounts for the 11DCA concentrations remaining several times higher than the 111 TCA levels.

The respective time-series plot of the RCRA groundwater sampling results for 111TCA (parent compoumd) and 11DCA (degradation product) show a widely fluctuating but decreasing concentration trend for $111 \mathrm{TCA}$ supported by linear regression trend line $\left(\mathrm{R}^{2}=0.48\right)$, and an indeterminate concentration tend for 1JDCA with a netrly flat or slightly increasing linear regression trend line $\left(\mathrm{R}^{2}=0.009\right.$ ) (Appendix A, Fig. 21). Temporal peak concentrations of both VOCs often correlate with seasonally high groundwater flow conditions, which suggests seasonally (and episodically) variable flux of VOCs along the groundwater flowpaths intercepted by the monitored interval in well GW-177. Also, historical data show that the concentrations of VOCs in the groundwater from this well (and other wells at the CRSP) rapidly decreased after the CRSP were closed and capped. For exanple, the concentration of $111 \mathrm{TCA}$ decreased from almost $100 \mu \mathrm{g} / \mathrm{L}$ in February 1989 to less than $10 \mu \mathrm{g} / \mathrm{L}$ in July 1990 . Since then, natural attenuation processes, including the chemical and/or microbiologically-mediated degradation noted above, have continued to slowly reduce the VOC concentrations such that asymptotic levels appear to have been achieved for some compounds (e.g., 11DCE). 


\subsection{RCRA PLUME BOUNDARY MONITORING DATA}

The following subsections describe the required evaluations of CY 2007 RCRA post-closure corrective action monitoring data reported for the RCRA plume boundary sampling locations (wells and springs) designated under site-specific conditions of the respective PCP for the Bear Cretk Regime (Appendix B, Table 1), Upper East Fork Regime (Appendix B, Table 2), and Chestnut Ridge Regime (Appendix B, Table 3).

\subsubsection{S-3 Site, Oil Landfarm, and Bear Creek Burial Grounds/Walk-In Pits}

The S-3 Site, Oil Landfarm, and BCBG/WIP share the following network of RCRA plume boundary monitoring locations: wells GW-712, GW-713, GW-714, and spring SS-6. The RCRA plume boumdaty wclls were installed in June 1991 (GW-712) and January 1992 (GW-713 and GW-714) and are completed at various depths within different hydrostratigraphic zones along a strike-normal transect across the Maynardville Limestone located apptoximately 5000 ft west of the BCBG/WIP (Appendix A, Fig. 14). Each well has black steel well casing and an open-hole monitored fnterval; construction details are included in Appendix B, Table 7. Spring SS-6 discharges groundwater from the Maynardville Limestone south of the main channel of Bear Creek approximately $700 \mathrm{ft}$ northwest of well GW-714 (Appendix A, Fig. 14). Detailed hydrologic data for the spring are not available, but flow appears to be perennial because the spring has never been dry during any scheduled statnpiing event over the past 16 years, including sampling performed during scasonally low flow conditions (summer and fall). More recently, a pond that forms behind a nearby beaver dam periodically submerges the spring.

The groundwater sampling hiștories for wells GW-712, GW-713, and GW-714 include non-RCRA exitpathway/perimeter monitoring (1991-1994) and RCRA post-closure cortective action monitoring (1995-present). Respective analytical results for each well show distinctive differences in groundwater geochemistry. The deeper plume boundary wells, GW-712 (457.5 ft bgs) and GW-713 (315.2 ft bgs), typically yield sulfate-enriched ( $550 \%$ of total ations) calcium-magnesium-bicarbonate groundwater distingufshed by fluoride concentrations near $0.5 \mathrm{mg} / \mathrm{L}$, total (and dissolved) strontium concentrations near I $\mathrm{mg} / \mathrm{L}$, and neutral to stightly basic $\mathrm{pH}(7.5-8.5)$. Conversely, the shallower plume boundary well, GW -714 ( $145.0 \mathrm{ft}$ bgs), yields calcium-magnesium-bicarbonate groundwater distinguished by much lower proportions of sulfate $(<10 \%)$, flutoride concentrations at or slightly above the PQL $(0.1 \mathrm{mg} / \mathrm{L}$ ), total (and dissolved) strontium concentrations near $0.1 \mathrm{mg} / \mathbf{L}$, and neutral to slightly acidic $\mathrm{pH}(6,0-7,5)$.

As shown by the CY 2007 RCRA sampling results summarized below in Table 18, excluding the falsepasitive results for methylene chforide, none of the RCRA groundwater target compounds were detected in the groundwater samples collected from well GW-712; low (background) levels of a gross beta activity and $\mathrm{U}-234$ were detected in one sample from well GW-713; and low levels of nitrate, U-234, and U-238 were detected in the samples from well GW-714. Complete analytical results for the groundwater samples from each well are in provided Appendix C. 
Table 18. CY 2007 sampllng results for RCRA groundwater target componnds detected in RCRA plume boundary wells GW-712, GW-713, and GW-714 in the Bear Creek Regine

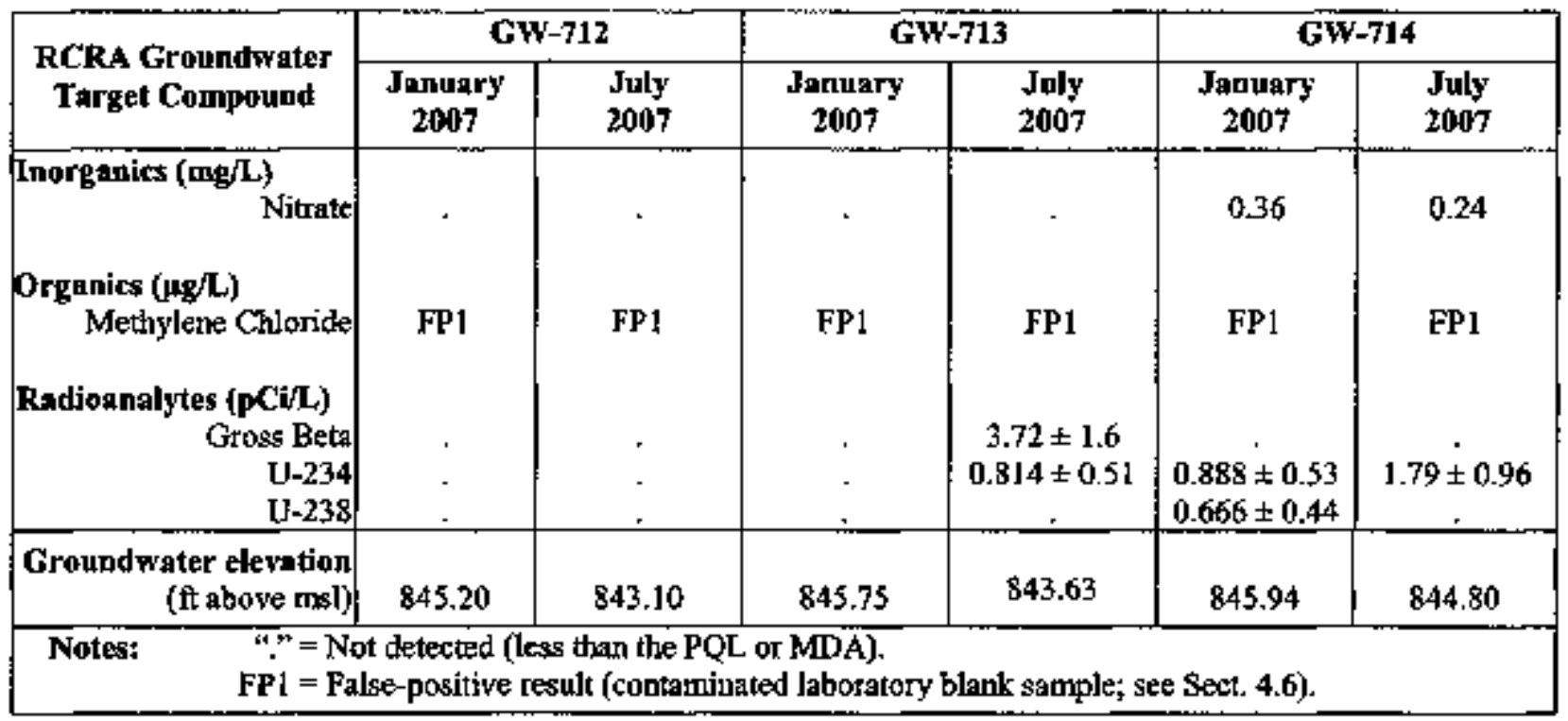

Semiannual RCRA groundwater sampling for spring SS-6 began in June 2004 when the spring replaced a well (GW-715) formerly designated as a RCRA plume boundary sampling location. The previous groundwater sampling history for the spring includes quarterly sampling (January 1991-November 1993), semíannual sampling (1995, 1998, 1999, and 2000), and annual sampling (2003) events. Analytical results for the groundwater samples collected to date show that spring SS-6 yields calcium-magnesium-bicarbonate groundwater characterized by low molar proportions of chloride, potassium, sodium, and sulfate (i.e., $<10 \%$ of total anions/cations); TDS ranging between 75 and $300 \mathrm{mg} / \mathrm{L}$; $\mathrm{pH}$ ranging from 6.76 to 8.64 (field messurements); and total concentrations of trace metals that are either below respective PQLs or are within the range of background levels in the Bear Creek Regime.

The RCRA groumdwater target compounds detected in the groundwater samples collected from spring SS-6 during CY 2007 are listed below in Table 19. Aside from the false-positive results for methylene chloride (see Sect. 4.6), these analytical results meet applicable DQOs, are consistent with histonical sampling results for the spring, and are within the respective range of background levels in the Bear Creek Regime and/or inherent analytical variability.

Table 19. CY 2007 sampling results for RCRA groundwater tariget constituents deteeted in RCRA plume boundary spring SS-6 in the Bear Creek Regime

\begin{tabular}{|c|c|c|}
\hline $\begin{array}{l}\text { RCRA Groumdwrater Target } \\
\text { Constituent }\end{array}$ & January 2007 & Jufy 2007 \\
\hline $\begin{array}{l}\text { Inorganics (mo/L) } \\
\text { Nitrate } \\
\text { Uranium } \\
\text { Organics }(\mu g / L) \\
\text { Methylene Chloride }\end{array}$ & $\begin{array}{c}0.38 \\
\cdot \\
\mathrm{FP2} \\
\end{array}$ & $\begin{array}{l}0.71 \\
0.01 \\
\text { FPI }\end{array}$ \\
\hline
\end{tabular}


Table 19. (continued)

\begin{tabular}{|c|c|c|c|c|}
\hline $\begin{array}{c}\text { RCRA Groundwater Target } \\
\text { Constituent }\end{array}$ & January 2007 & \multicolumn{3}{|c|}{ July 2007 } \\
\hline $\begin{array}{r}\text { Radionalytes (pCiL) } \\
\text { Gross alpha activity } \\
\text { Gross beta activity } \\
\mathrm{U}-234 \\
\mathrm{U}-238 \\
\end{array}$ & $\begin{array}{lll}3.64 \pm & \pm & 1.9 \\
0.564 \pm & \pm & 0.321 \\
0.932 & \pm & 0.422 \\
\end{array}$ & $\begin{array}{l}4.77 \\
6.33 \\
0.743\end{array}$ & $\begin{array}{l} \pm \\
\pm \\
\pm\end{array}$ & $\begin{array}{l}2.27 \\
2.38 \\
0.546\end{array}$ \\
\hline $\begin{aligned} \text { ".5 } & =\text { Not detected } \\
\text { FP1 } & =\text { False-positive } \\
\text { FP2 } & =\text { False-positive }\end{aligned}$ & $\begin{array}{l}\text { PQL or MDA) } \\
\text { anuated laborato } \\
\text { aninated trip blan }\end{array}$ & ct. & & \\
\hline
\end{tabular}

The PCP for the Bear Creck Regime (Appendix A, Table 1) requires evaluation of the RCRA groundwater monitoring data for wells GW-712, GW-713, GW-714, and spring SS-6 to be based on quantitative trend analysis of the amalytical results for nitrate, uranium, TCE, and Tc-99. These RCRA groundwater target compounds are representative of the most mobile and/or pervasive components of the commingled contaminant plume in the Aquifer (Maynardville Limestone) hydraulically upgradient to the east (see Sect. 3.4.1.4). However, none of these constituents have been detected consistently in the groundwater samples collected to date from wells GW-712 and GW-713, both of which intereept low permeability flowpaths at depth in the Maytardville Limestone. Also, TCE and Tc-99 are rately if ever detected in the groundwater samples from any of the RCRA plume boundary monitoring locations. Based on these conșiderations, only the nitrate concentration trends for well GW-714 and spring SS-6 were evaluated per the requirements of the above-referenced permit conditions. Each trend analysis was based on a time-series plot of the RCRA post-closure groundwater monitorinig results obtained since January 1998, with the relative direction (upward or dowmward) of each trend determined by least-squares linear regression of the respective time-series data. Non-detected results were exeluded from the regression analyses, as were results that do not meet applicable DQOs, including nitrate results for samples with unacceptable charge-balatuce errers.

Respective time-series plots of the nitrate data for well GW-714 and spring SS-6 are shown on Appendix A, Fig. 22. The nitrate trend for well GW-714 is dominated by a peak concentration in January $2001(3.7 \mathrm{mg} / \mathrm{L})$ followed by lower and steadily decreasing levels that have remained below $1 \mathrm{mg} / \mathrm{L}$ since July 2004 and do not exhibit significant seasonal fluctuations. The RCRA sampling results for nitrate in groundwater from spring SS-6 show similarly low levels that exhibit much more temporal (seasonal) varjability and define a decreasing linear regression trend line $\left(R^{2}=0.16\right)$.

Based on the CY 2007 RCRA post-closure groundwater monitoring data for wells GW-712 and GW-713 and the respective trends of background nitrate concertrations continued by the $C Y 2007$ sarmpling results for well GW-714 and spring SS-6, each of these groundwater sampling locations temain suitable for the RCRA plume boundary motitoting purposes defined in the PCP for the Bear Creek Regime.

\subsubsection{Eastern S-3 Slte Plume}

In accordance with the PCP for the Upper East Fork Regime (Appendix A, Table 3), detection of Te-99 (i.e., >MDA and TPU) in the groundwater sanples from the designated RCRA plume boundary wells (GW-193, GW-605, GW-606, and GW-733) is considered indicative of contaminant migration from the Eastem S-3 Site Plume because no other site in the Upper East Fork regime received wastes that contained the radionuclide. The Tc-99 results reported for the groundwater samples collected from the 
RCRA plume boundary wells during CY 2007 are all less than the applicable MDA (see data in Appendix D). Accordingly, these wells remain suitable for the RCRA plume boundary monitoring purposes defined in the PCP for the Upper East Fork Regime.

\subsubsection{Chestnut Ridge Security Pits}

As notod in Sect 4.1.3, the RCRA plume boundary sampling locations designated for the CRSP are located more than 1000 in to the cast (GW-301), southeast (GW-562, GW-557, GW-799, and spring SCR4.3SP), south (GW-801), and southwest (GW-831) of the site (Appendix A, Fig. 16). The wells were installed between July 1987 (GW-301) and July 1996 (GW-831), each well constructed with stainless steel riser casing and continuous wire-wound sereen (0.01 in. slot). Complete well construction information for each of these wells is provided in Appendix B, Table 7.

In accordance with the new PCP for the Chestut Ridgc Regime (sce Sect. 1), VOCs are defined as RCRA groundwater target compounds for the RCRA plume boundary sampling locations (Appendix B, Table 10). None of these VOCs were detected in the groundwater samples collected from the RCRA plume boundary sampling locations during CY 2007 (see data in Appenđix E.1). Accordingly, wells GW-301, GW-557, GW-799, GW-801, and GW-831 and spring SCR4.3SP remain suitable for the RCRA plume boundary monitoring purposes defined in the PCP for the Chestnut Ridge Regime.

\subsection{RCRA POST-CLOSURE DETECTION MONITORING DATA}

\subsubsection{Chestnat Ridge Sediment Disposal Basin}

None of the RCRA groundwater target constituents for the CRSDB (cadmium, chromium, lead, mescury, nickel, silver, and total uranium) were detected (i.e., $>\mathrm{PQL}$ ) in the groundwater samples collected during CY 2007 from upgradient/background well GW-159 and POC wells GW-159, GW-731, and GW-732 at the site (see data in Appendix E.2). Accordingly, these results do not indieate a telease of contaminants to the uppermost aquifer at the CRSDB.

\subsubsection{Kerr Hollow Quarry}

Uranium is the only RCRA groundwater target compound for KHQ that was detected in the groundwater samples collected during CY 2007 from upgradient/background well GW-231 and POC wells GW-I43, GW-144, and GW-145 at the site (see data in Appendix E.3). Statistical evaluation of the uranium results in accordance with the procedure specified in the PCP for the Chestnut Ridge Regime was completed within 90 days of the ammal RCRA grounowwater sampling event, as required by the PCP (Appendix B, Table 3). The results of the statistical evaluations do not indicate a release of contaminants to the uppermost aquifer at KHQ (sce the site-specific statistical data evaluation report in Appendix E.5).

\subsubsection{East Chestnut Ridge Waste Pile}

Ten inorganic constituents (e.g., metals and anions) and gross alpha activity are the RCRA groundwater target compounds for the ECRWP detected in the groundwater samples collected during CY 2007 from upgradient/background well GW-294 and POC wells GW-161, GW-292, GW-293, GW-296, and 
GW-298 (see data in Appendix E.4). Analytical tesults for the groundwater samples from the POC wells indicate concentrations of barium (GW-292 and GW-293), chloride (GW-292 and GW-293), chromium (GW-292), and nickel (GW-292) above background levels. Statistical evaluation of these results in accordance with the procedure specified in the $\mathrm{PCP}$ for the Chestnut Ridge Regime was completed within 90 days of each semiannual RCRA groundwater sampling event, as required under by the PCP (Appendix B, Table 3). Based on evaluation of the data, the elevated concentrations of barium, chloride, chromium, and nickel are most likcly attributable to natural or in-situ geochenical conditions and, as such, do not serve as reliable indicators of potential contaminant relcase for the ECRWP (see site-specific statistical data craluation reports in Appendix E.5).

The elevated nickel and chromium concentrations reported for POC well GW-292 were reported to TDEC in March 2007 in a teleconference initiated by BJC personnel (BJC 2007b). It was agreed that the nicke] and chromium concentrations do not indicate a release to groundwater from the ECRWP and are most likely attributable to chemical and/or microbiologically induced corrosion of the stainless steel well casing and/or screen. Furthermore, TDEC personnel suggested retaining well GW-292 in the monitoring network for the ECRWP because, regardless of the false-positive nickel and chromium results, the well is suitable for detection monitoring for the primary contaminants (VOCs and gross alpha activity).

The elevated barium and chloride concentrations in groundwater samples from POC wells GW-292 and GW-293 also were discussed with TDEC personnel. It was agreed that the concentrations reflect natural geochemical variation in the groundwater near the site and the low levels pose no risk to the environment.

As noted previously (see Sect 4.1.6), the PCP for the Chestnut Ridge Regime requires only three of the five POC wells to be included in each sampling event. Beginning in CY 2008, wells GW-161, GW-296, and GW-298 will serve as the ptimary POC wells at the site.

\section{LEACHATE SAMPLING DATA}

As required by the PCP for the Chestnut Ridge Regine (Appendix A, Table 3), samples of the leachate in the collection tank at the ECRWP were collected during CY 2007 and were analyzed for the inorganic constítuents, VOCs, and radioanalytes (gross alpha and gross beta activity) specified in the PCP (Attachment 3, Table 3-6). Although the PCP requires annual sample collection, the BJC environmental sampling subcontractor collected the leachate samples semiannually to evaluate the leachate with respect to treatment system waste acceptance criteria. Analytical results for the constituents detected in either leachate sample are summarized below; the complete analytical results for the samples are in Appendix B, Table 16. Note that the leachate sample collected in March 2007 was not analyzed for three of the inorganic analytes because of miscommunication with the anglytical laboratory (only one of these anatytes, boron, is a RCRA groundwater target compound for the ECRWP). Results for all analytes were obtained for the sample collected in August 2007.

As shown in Table 20, the principal inorganic constituents detected $(>20 \mathrm{mg} / \mathrm{L})$ in the leachate samples are chloride and sodium, and the principal VOCs ( $>10 \mu \mathrm{g} / \mathrm{L}$ ) are IIITCA, IIDCA, chloroethane, and cl2DCE. Each leachate sample had relatively low levels of gross alpha activity and gross bets activity. These analytical results are consistent with those reported for previous samples of leachate from the ECRWP. 
Table 20. Sumnary of CY 2007 leachate samplng results for the ECRWP

\begin{tabular}{|c|c|c|c|}
\hline Leachate Angiytes & $\begin{array}{l}\text { RCRA Groundwater } \\
\text { Target Componnd }\end{array}$ & March 2007 & August 2007 \\
\hline $\begin{array}{r}\text { luorganies (mg/L) } \\
\text { Batrium } \\
\text { Boron } \\
\text { Chloride } \\
\text { Iron } \\
\text { Eithium } \\
\text { Mangaurese } \\
\text { Nitrate } \\
\text { Potassium } \\
\text { Sodium } \\
\text { Strontium } \\
\text { Sulfate } \\
\text { Uranium }\end{array}$ & $\begin{array}{l}: \\
: \\
: \\
: \\
: \\
: \\
- \\
- \\
-\end{array}$ & $\begin{array}{l}0.0406 \\
\mathrm{NA} \\
41 \\
0.418 \\
0.136 \\
0.0196 \\
0.34 \\
\mathrm{NA} \\
\mathrm{NA} \\
0.366 \\
6 \\
0.0146\end{array}$ & $\begin{array}{c}0.0437 \\
0.332 \\
42.2 \\
0.151 \\
0.75 \\
0.88 \\
20.2 \\
0.41 \\
6.4 \\
0.0115\end{array}$ \\
\hline 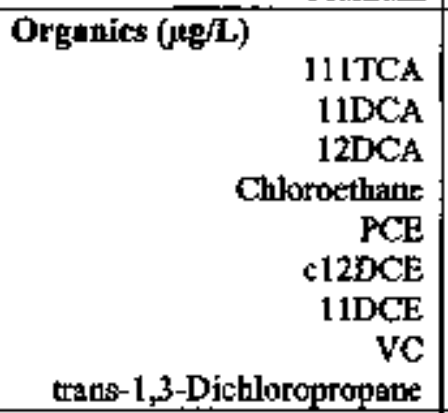 & $\begin{array}{l}\bullet \\
\bullet \\
- \\
- \\
: \\
- \\
-\end{array}$ & $\begin{array}{r}58 \\
360 \\
13 \\
2 \mathrm{~J} \\
380 \\
5 \\
1 \mathrm{~J}\end{array}$ & $\begin{array}{c}24 \\
130 \\
1 \mathrm{~J} \\
45 \\
93 \\
2 \mathrm{~J} \\
2 \mathrm{~J} \\
.\end{array}$ \\
\hline $\begin{array}{r}\text { Rodíonalytes (pCi/L) } \\
\text { Gross alpha activity } \\
\text { Gross beta activity }\end{array}$ & $\stackrel{-}{-}$ & $\begin{array}{r}9.42 \pm 1.45 \\
11.5 \pm 1.83\end{array}$ & $\begin{array}{rll}5.84 & \pm 1.17 \\
10 & \pm & 1.85\end{array}$ \\
\hline $\begin{aligned} \text { NA } & =\text { Not analyze } \\
\text { "." } & =\text { Not detecte } \\
\text { J } & =\text { Estimated }\end{aligned}$ & centration. & & \\
\hline
\end{tabular}

Under the site-speeific requirements in the PCP for the Chestnut Ridge Regime (Appendix B, Table 3), analytical results for the leachate samples must be evaluated annually to determine if the results warrant the addition of any analytes to the list of RCRA groundwater target compounds specified for the ECRWP (Appendix B, Table 10). As shown in Table 20, the lcachate samples contained six analytes that are not included on the list: potassium, sodium, strontium, chloroethane, trans-1,3-dichloropropane, and gross beta activity. Potassizm, sodium, and strontium were originally on the list of groundwater target compounds; however, based on waste characterization, these inorganics were removed from the list during the commentrresponse process for the PCP (Comment \#21). As noted in Sect. 4.3.6, chloroethane is not listed as a RCRA groundwater target compound because of a typographical etror that identiffes "chloromethane" instead (note that chloromethane was not detected in either of the leachate samples collected during CY 2007). The trace level of trans-1,3-dichloropropane detected in the leachate sample collected March 2007 is probably an analytical artifact considering that this compound was not detected in any of the previous leachate samples or in the sample collected in August 2007. Gross beta activity was detected at low levels ( $<15 \mathrm{pCi} / \mathrm{L}$ ) in both leachate samples, which is substantially below the SDWA screening level ( $50 \mathrm{pCi} / \mathrm{L}$ ) for a 4 millirem per year dose equivalent (the drinking water MCL for gross beta activity). 
Aside from correcting the above-noted typographical eror such that chloroethane is properly identified in the PCP (Attachment 7, Table 7.1-1), the CY 2007 leachate sampling results do not warrant any additions to the ist of RCRA groundwater target compounds specified for the ECRWP. Notably, about half of the RCRA groundwater target compounds (12 trace metals and seven VOCs) were not detected in the leachate samples collected duting CY 2007.

\section{REFERENCES}

BJC (Bechtel Jacobs Company LLC) 1998. East End VOC Plume Pump and Tracer Test Technical Memorandum, BJC/OR-103, Bechtel Jacobs Company LLC, Oak Ridge, TN.

BJC 2006. Sampling and Analysis Plan for the Water Resources Restoration Program for Fiscal Year 2007, Oak Ridge Reservation, Oak Ridge, Tennessee, BJC/OR-2518, Bechtel Jacobs Company LLC, Oak Ridge, TN.

BJC 2007a. Thompson, R,W., August 28, 2007. BJC letict to M. Apple, 1DEC; subject: "Semiannual Post-Closure Groundwater Monitoring Report for the Bear Creek, Chestnut Ridge, and Upper East Fork Poplar Creek Hydrogeologic Regimes at the Y-12 National Security Complex (TN3 89009 0001); First Semiannual Reporting Period for Calendar Year 2007." Bechtel Jacobs Company LLC, Oak Ridge, TN.

BIC 2007b. Ketelle, R. and Bricken, E. March 15, 2007. BJC teleconference with C. Butlington, TDEC; subject: Elevated nickel and chromium concentrations in groundwater samples from point-ofcompliance well GW-292 at the East Chestnut Ridge Waste Pile.

Connell, J.F. and ZC. Bailey 1989. Statistical and Simutation Analysis of Hydratlic Conductivity Data for Bear Creek and Melton Valleys, Oak Ridge Reservation, Tennessee. U.S. Geological Survey Water-Resources lnvestigations Report 89-4062.

DOE (U.S. Department of Energy) 1995a. Oak Ridge Reservation Site Management Plan for the Environmental Restoration Program, DOE/OR-1001/R4, U.S. Department of Energy, Office of Environmentat Management, Oak Ridge, TN.

DOE 1995b. Record of Decision for Kerr Hollow Quarry at the Oak Ridge Y-12 Plant, Oak Ridge, Tennessee, DOE/OR/02-1398\&D2, U.S. Department of Energy, Office of Eavironmental Martagement, Oak Ridge, TN.

DOE 1997. Report an the Remedial Investigation of Bear Creek Valley at the Oak Ridge Y-12 Plant. Oak Ridge, Tennessee, DOE/OR/01-1455/V1\&D2, Volume 1, U.S. Department of Energy, Office of Environmental Management, Oak Ridge, TN.

DOE 1998. Report on the Remedial Investigation of the Upper East Fork Poplar Creet Characterization Area at the Oak Ridge Y-12 Plant, Oak Ridge, Tennessee, DOE/OR/01-1641/D1\&V1, U.S. Department of Energy, Office of Environmental Management, Oak Ridge, TN. 
DOE 1999. Action Memorandum for the Oak Ridge Y.12 Plant East End Volatile Organic Compound Plume, Oak Ridge, Tennessee, DOE/OR/1-1819\&D2, U.S. Department of Energy, Office of Envitonmental Management, Oak Ridge, TN.

DOE 2002a. Record of Decision for Phase I Interim Source Control Actions in the Upper East Fork Poplar Creek Characterization Area at the Oak Ridge Y-12 Plant, DOEJOR/01-1951\&D3, U.S. Departinent of Encrgy, Office of Environmental Management, Oak Ridge, TN.

DOE 2002b. 2001 Remediation Effectiveness Report/CERCLA Five-Year Review for the U.S. Department of Energy, Oak Ridge Reservation, Oak Ridge, Tennessee, DOE/OR/01-1941\&D2/R1, U.S. Department of Energy, Office of Environmental Management, Oak Ridge, TN.

Dreier, R.B., Solomon, D.K., and Beaudoin, C.M. 1987. Fracture Characterization in the Unsaturated Zone of a Shallow Land Burial Facility. Flow and Transport through Fractured Rock. American Geophysical Union Monograph 42.

Energy Systems (Martin Marietta Energy System, Inc.) 1984. Site Characterization of the West Chestrut Ridge Site. Oak Ridge National Laboratory, ORNL/TM-9229, Martin Marietta Energy Systems, Inc., Oak Ridge, TN.

Energy Systems 1987, Subsufface-Controlled Geological Maps for the Y-J2 Plant and Adjacent Areas of Bear Creek Valley, TM-10112, Martin Marietta Energy Systems, Inc., Oak Ridge, TN [cited on maps in Appendix A, Fig. 5, pg A-5, and Appendix A, Fig. 6, pg A-6].

Energy Systems 1988a. Concepts of Groundwater Flow and Occurrence Near Oak Ridge National Laboratary, Tennessee, ORNL/TM-10969, Martir Marietta Energy Systems, Inc., Oak Ridge, TN.

Energy Systems 1988. Summary of Results and Preliminary Interpretation of Hydrogeologic Packer Testing in Core Holes GW-131 Through GW-135 and CH-1S7, Oak Ridge Y-12 Plant, Y/TS-495, Martin Marietta Energy Systems, Inc., Oak Ridge, TN.

Energy Systems 1989a. Groundwater Parameters and Flow System Near Oak Ridge National Laboratory, ORNL/TM-11368, Martin Marietta Energy Systems, Jne., Oak Ridge, TN.

Energy Systerns 1989b. Development of Grotind-Water Flow Models for the $S-3$ Waste Management Area, Y-12 Plant, Oak Ridge, Tennessee, Y/SUB/89-00206Cl, Martin Marietta Energy Systems, Inc., Oak Ridge, TN.

Energy Systems 1989c. Tracer Study of the Hydrologic System of Upper Bear Creek, Y-12 Plant, Oak Ridge, Tennessee, Y/SUB/89-00206C/4, Martin Marietta Energy Systems, Inc., Oak Ridge, TN.

Energy Systems 1990. Groundwater Quality Assessment for the Bear Creek Hydrogeologic Regime at the Y-I2 Plant, I989: Data Interpretations and Proposed Modifications, Y/SUB/90-00206C/1 Part II, Martin Marietta Energy Systems, Inc., Oak Ridge, TN.

Energy Systems 1992a. Sfatus Report-A Hydrologic Framework for the Oak Ridge Reservation, ORNL/TM-12053, Martin Marietta Energy Systems, Inc., Oak Ridge, TN.

Energy Systems 1992b. Supplement to a Hydrogeologic Framework for the Oak Ridge Reservation, Oak Ridge, Tennessee, ORNL/TM-12191, Martin Marietta Energy Systems, lnc, Ork Ridge, TN. 
Energy Systems 1993a. Summary of Fiscal Years 1991 and 1992 Construction. Hydrologic, and Geological Data Obtained from the Maynandville Limestone Exit Pathway Monitoring Program, Y/TS-814, Martin Marietta Energy Systems, Inc., Oak Ridge, TN.

Energy Systems 1993b. Finat Report of the Second Dye-Tracer Test at the Chestrut Ridge Security Pits, $Y_{n}$ I2 Plant, Oak Ridge, Tennessee, Y/SUB/93-99928C/Y10/1, Martin Marietta Energy Systems, Inc., Oak Ridge, TN.

Energy Systems 1994a. Water Balance Report for the Oak Ridge Y-12 Plant, SUB/28B-99920C/92-4, Martin Marietta Energy Systems, Inc., Oak Ridge, TN.

Energy Systems 1994b. Chemical Characteristics of Waters in Karst Formations at the Oak Ridge Y-12 Plant, Y/TS-100L, Martin Marietta Energy Systems, Inc., Oak Ridge, TN.

Energy Systems (Lockheed Martin Enctgy Systems, Inc.) 1995a. Distribution of Anthropogenic Fill Material within the Y-12 Plant Area, Oak Ridge. Tentessee, Y/TS-1387, Lockheed Martin Energy Systems, Inc., Oak Ridge, TN.

Energy Systems 1995b. Stratigraphic Variations and Secondary Porosty within the Maynardville Limestone in Bear Creek Valley. Y-12 Plant, Oak Ridge, Tennessee, Y/TS-1093, Lockheed Martin Energy Systems, Inc., Oak Ridge, TN.

Encrgy Systems 1995c. Evaluation of Cross Borehole Tests at Selected Wells in the Maynardville Limestone and Copper Ridge Dolomite at the Oak Ridge Y-12 Plant, YTS-1166, Martin Marietta Energy Systems, Inc., Oak Ridge, TN.

Energy Systerns (Lockheed Martin Energy Systems, Inc.) 1996a. Calendar Year I995 Groundwater Quality Report for the Chesinut Ridge Hydrogeologic Regime, Y I2 Plant, Oak Ridge. Tennessee. Part 2: 1095 Groundwater Quality Data Interpretations and Proposed Program Modifications. Y/SUB/96-KDS15V/2, Lockheed Martin Enexgy Systems, Inc., Oak Ridge, TN.

Entrgy Systems 1996b. Effective Porosity and Pore-Throat Sizes of Conasauga Group Mudrock: Application, Test, and Evaluation of Petrophysical Techniques, ORNL/GWPO-021, Lockheed Martin Energy Systems, Inc., Oak Ridge, TN.

Energy Systems 1997a. Jones, S.B. February 12, 1998. Energy Systems letter to J.R. Walker, AJA Technica! Services, Inc.; subject: "Hydraulic Conductivity Estimates from Landfills in the Chestnut Ridge Hydrogeologic Regime at the Y-12 Plant, 1994-1997."

Energy Systems 1997b. Effective Porosity and Densiny of Carbonate Rocks (Maynardville Limestone and Copper Ridge Dolomite) within the Bear Creet Valley on the Oak Ridge Reservation Based on Madern Petrophysical Techniques, ORNL/GWPO-026, Lockheed Martin Energy Systems, Inc., Oak Ridge, TN.

EPA (U.S. Environmental Protection Ageticy) 1988. Laboratory Validation Functional Guidelines for Evaluating Organics Anolyses.

Gee, G.W., Rai, D., and Serne, R.J. 1983. Mobility of Radionuclides in Soil. In: Chemical Mobility and Reactivity in Soil Systems. Soil Science Society of America, Inc. Madjson, WI (pp 203-227). 
McCany, P.I. 1996. Biotic and Abtotic Transformations of Chlorinated Solvents in Groundwater. Reported in: Symposium on Natural Attenuation of Chlorinated Organics in Groundwater, EPA/540/R-96/509, U.S. Environmental Protection Agency, Office of Research and Development

Moore, G.K. 1992. Hydrograph analysis in fractured rock terrain. Ground Water, Vol. 30, No. 3, pp. 390395.

Quinlan, J.F. and R.O. Ewers. 1985. Groundwater Flow in Limestone Terrains: Strategy, Rationale and Procedure for Reliable, Efficient Monitoring of Groundwater Quality in Karst Areas. National Symposium and Exposition on Aquifer Restoration and Groundwater Monitoring Proceedings, National Water Well Association, Worthington, $\mathrm{OH}$ (pp. 197-234).

TDEC (Tennessee Department of Environment and Conservation) 1997. Recognition of Class I and Class'1 Modifications, New Hope Pond and Eastern S-3 Pond Units (Post Closure Permit), Y-12, Upper East Fork Poplar Creek Hydrogeologic Regime. Letter to the U.S. Department of Energy and Lockheed Martin Energy Systems, Inc.

TDEC 2006. Final Post-Closure Issuance, Chestnut Ridge Hydrogeologic Regime, U.S. DOE Y.12 National Security Complex, Oak Ridge, Tennessee, EPA ID Number: TN3 89009 001, TN Permit Number: TNHW-128, Septenber 29, 2006.

ThermoNUtech 1999. Petsonal communication from W. McDowell to T.R. Harrison, AJA Technical Services, Inc, regarding analytical interferences associated with kinetic phosphorescent analysis for uranium.

Watson, K.W. and RJ. Luxmoore. 1986. Estimating Macroporasity in a Forested Watershed by use of a Tension Infiltrometer. Soil Science Society of America, Journal 50 (pp. 578-582).

Weidemeier, T.H., H.S. Rifai, G.J. Newell, and J.T. Wilson. 1999. Natural Attenuation of Fuels and Chlorinated Solvents in the Subsurface. John Wiley \& Sons, Inc., New York, NY.

Wilson, G.V. and R.J. Luxmoore. 1988. Infiltration, Macroporosiby, and Mesoporasity Distributions of two Fortested Wotersheds. Soil Science Society of America, Joumal 52 (pp. 329-355). 
APPENDIX A

FIGURES 


\section{FIGURES}

1 Hydrogeologic regimes at the Y-12 National Security Complex...............................................A-4

2 Waste management sites and regulated units in the Bear Creek Hydrogeologic Regime ...................A-5

3 Fill areas and preconstruction frainage features in the Upper East Fork Poplar Crek

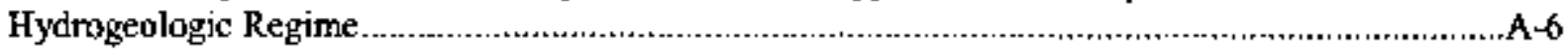

4 Waste management sites in the Chestnut Rjdge Hydrogeologic Regime ....................................A-7

5 Topography and bedrock geology in the Bear Creek HIydrogeologic Regime ,..................................

6 Topography and bedrock geology in the Upper East Fork Poplar Croek

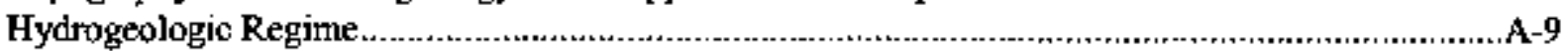

7 Topography and bedrock geology in the Chestnut Ridge Hydrogealogic Regitne .........................A-10

8 Groundwater eicvations in the Bear Creek Hydrogeologsic Regime, April 2007 ............................11

9 Ground water elevations in the Upper East Fork Poplar Creek

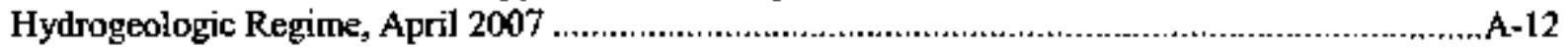

10 Groundwater elevations in the Chestriut Ridge Hydrogeologic Regime, Aptil 2007 .....................A-13

11 Generalized extent of groundwater contamination in the Bear Creck Hydrogeologic Regime..........A-I4

12 Generalized extent of groundwatet contamination in the Upper East Fork Poplar Creek

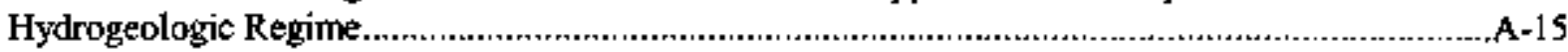

13 Generalized extent of groundwater contamination in the Chestnut Ridge Hydrogeologic Regime.

14 RCRA post-closure groundwater monitoring locations in the Bear Creek Hydrogeologic Regime

15 RCRA post-closure groundwater monitoring locations in the Upper East Fork Poplar Creek Hydrogeologic Regime

I6 RCRA post-closure groundwater monitoring locations in the Chestnut Ridge Hydrogeologic Regime

17 Nitrate, Tc-99, PCE, and uranium concentration trends at S-3 Site point-of-compliance well GW-276.

$18 \mathrm{PCE}, \mathrm{TCE}$, and $\mathrm{c}$ 12DCE concentration trends at Oil Landfarm point-of-compliance well GW-008. 
19 Concentration trends for seleeted VOCs at Bear Creek Burial Grounds $f$ Walk-ln Pits point-of-compliance well GW-046

20 Nitrate, chloroform, and Tc-99 concentration trends at Eastem S-3 Site Plume point-of-compliance well GW-108.

21 I IITCA and 11DCA concentration trends at Chestnut Ridge Security Pits point-of-compliance well GW-177.

22 Nitrate concentration trends at RCRA plume boundary weil GW-7/4 and spring SS-6. A.25 


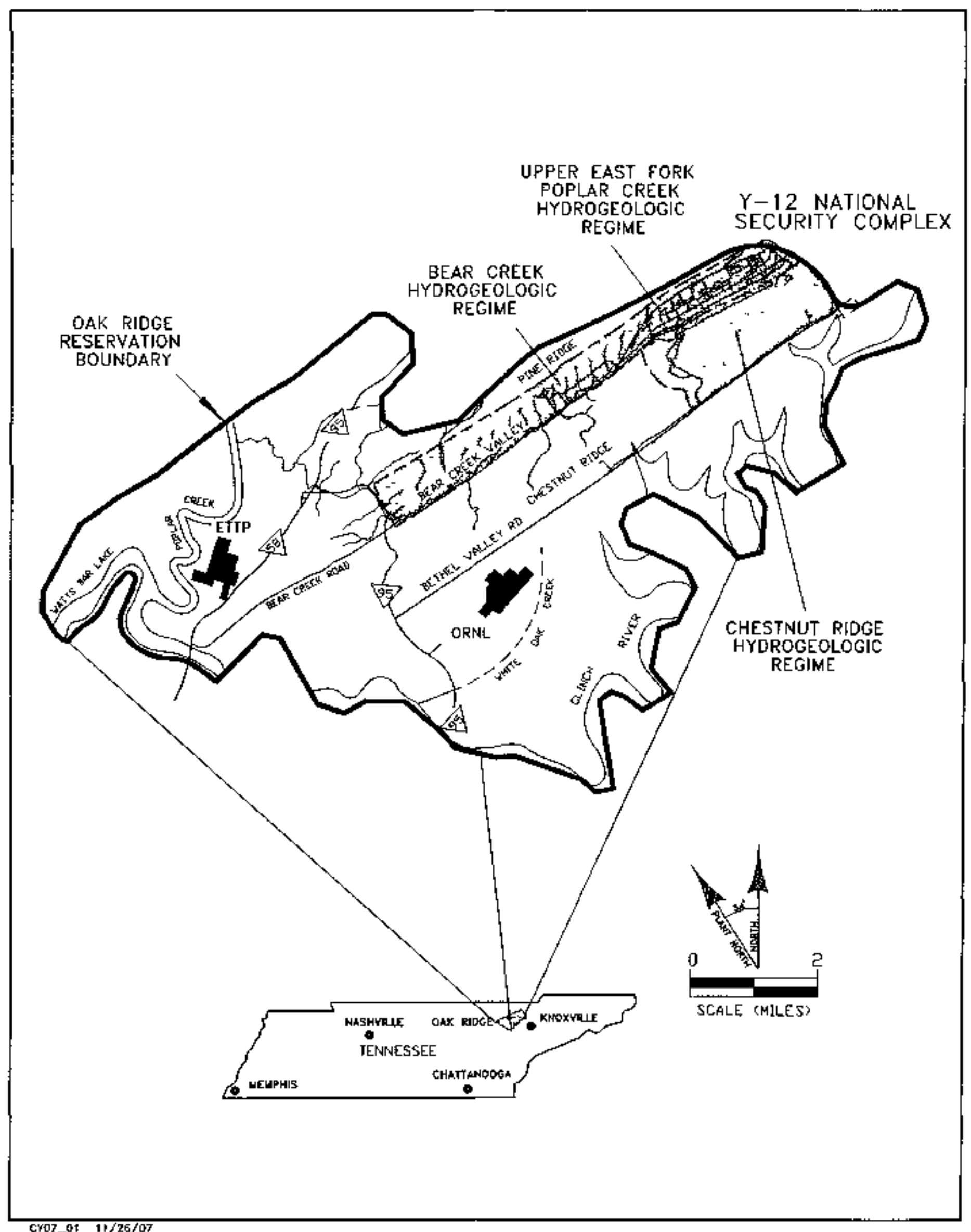

Fig. 1. Hydrogeslogite regimes at the Y-12 National Security Complex. 


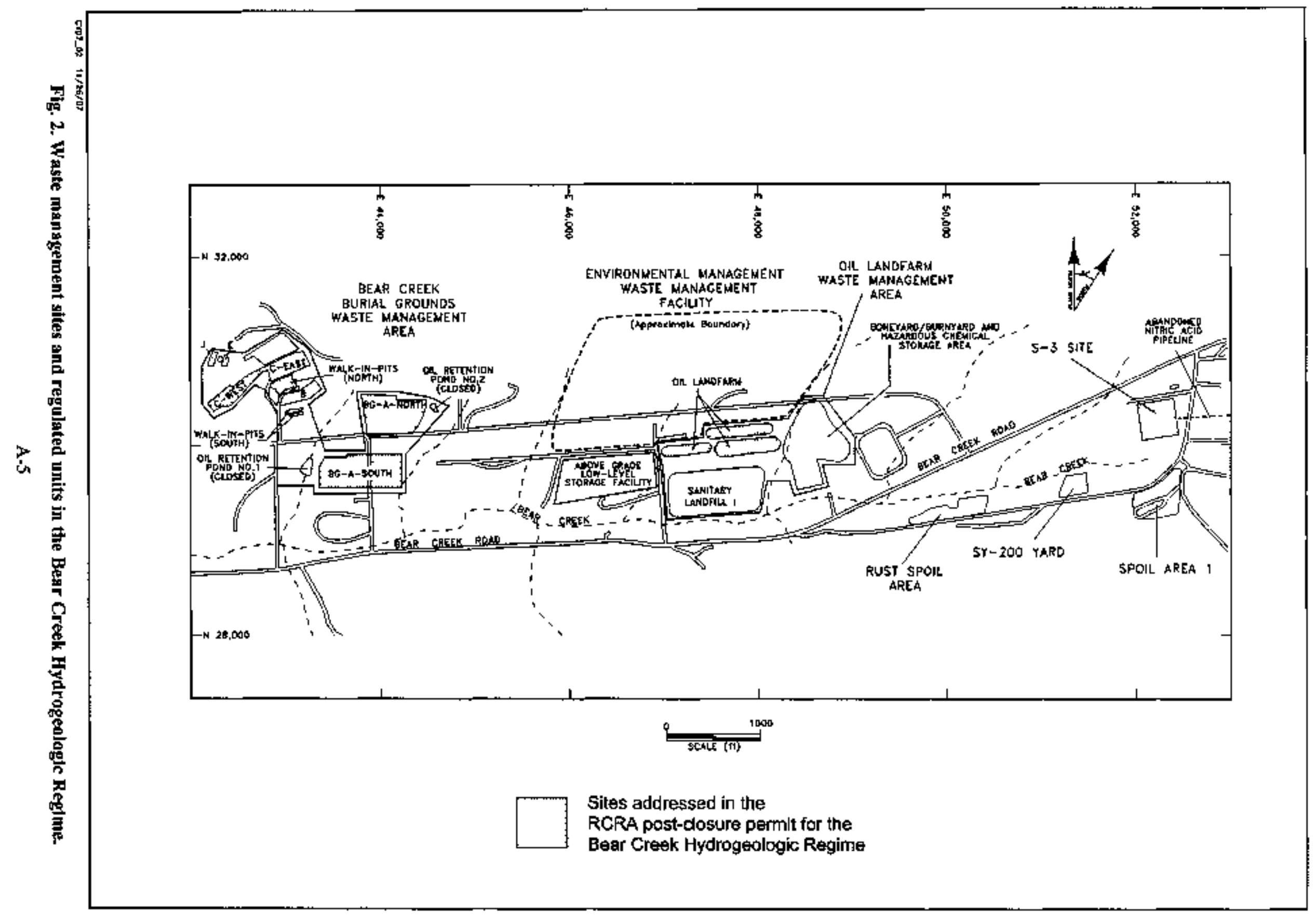




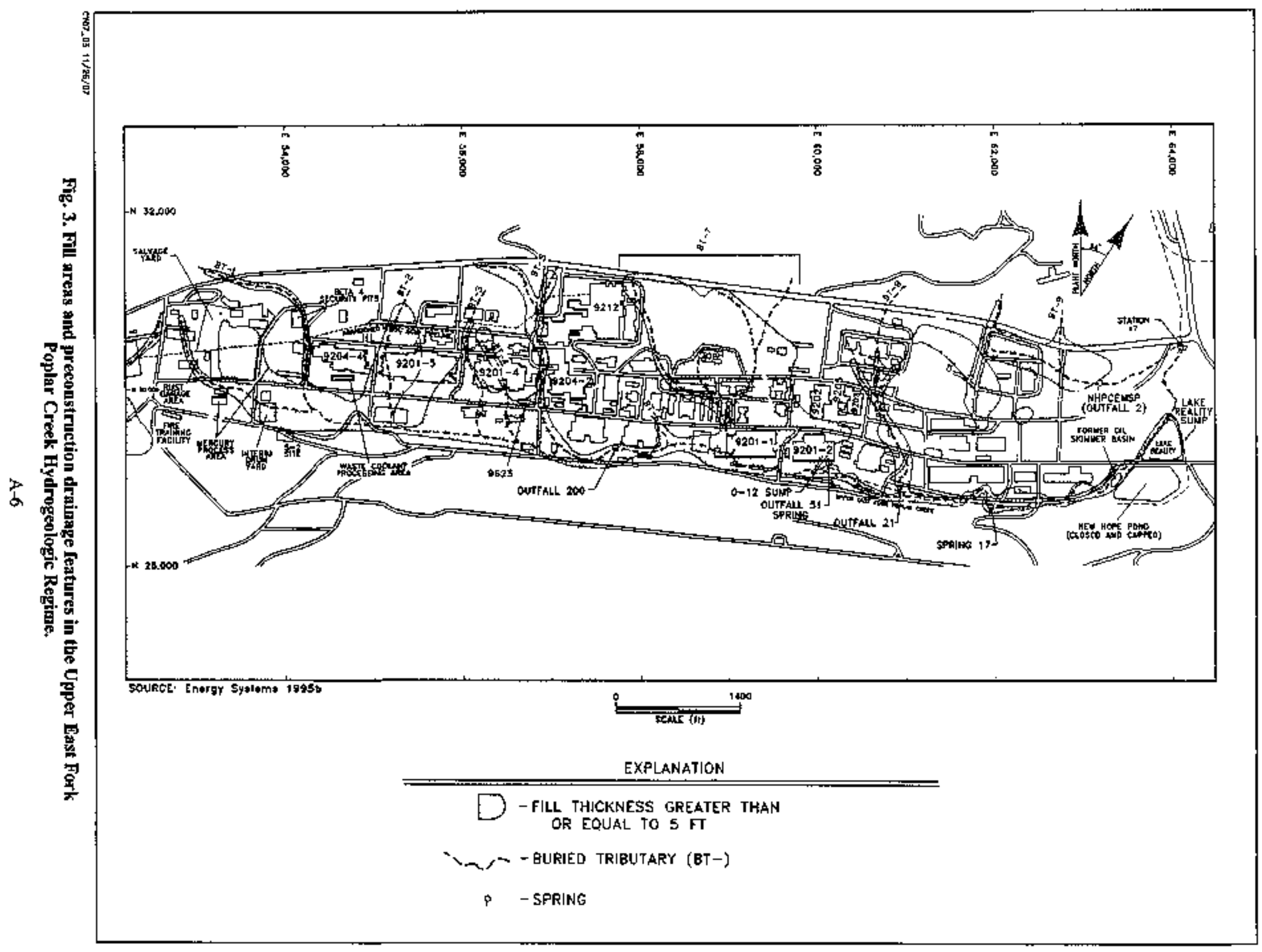




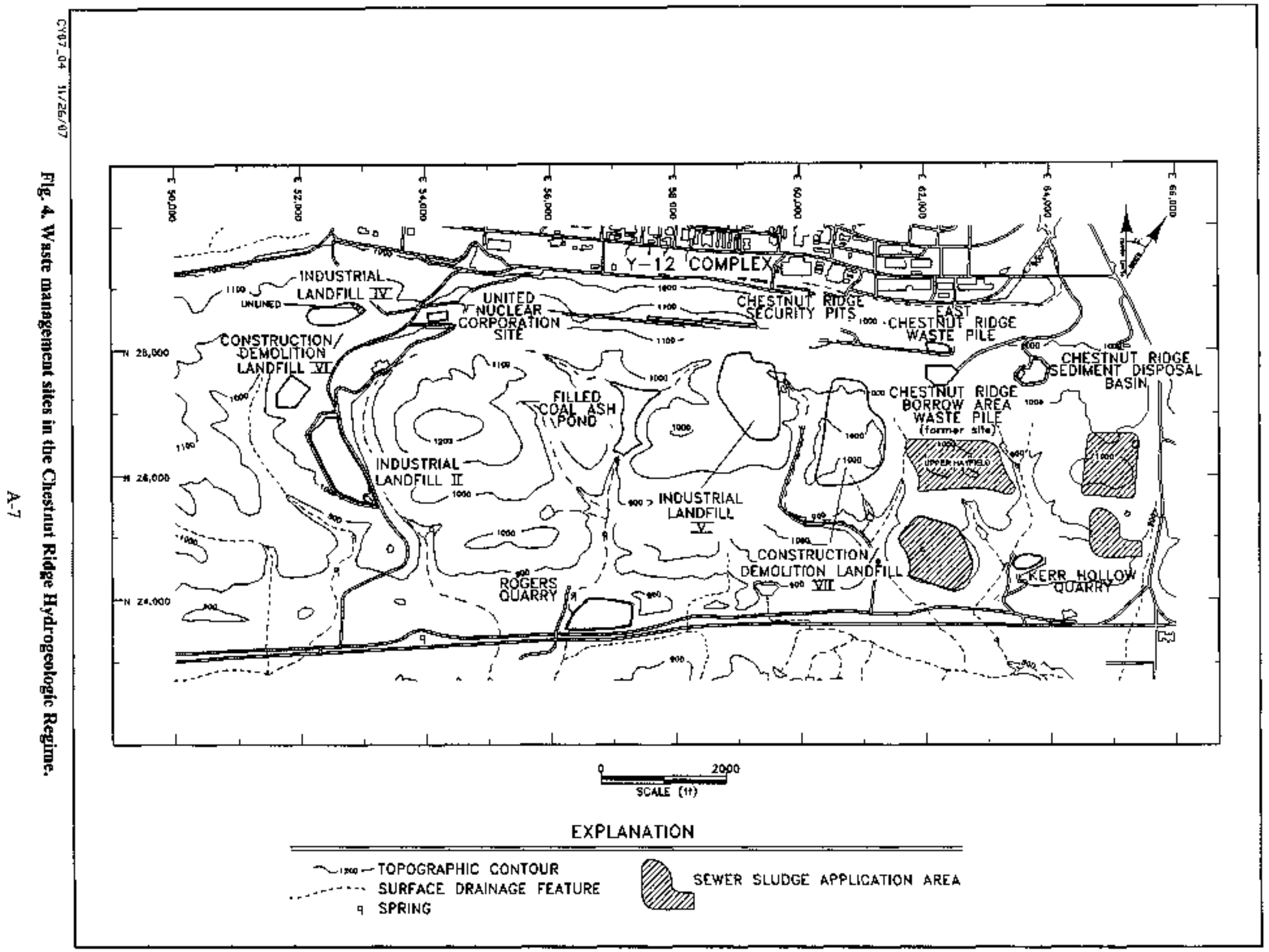




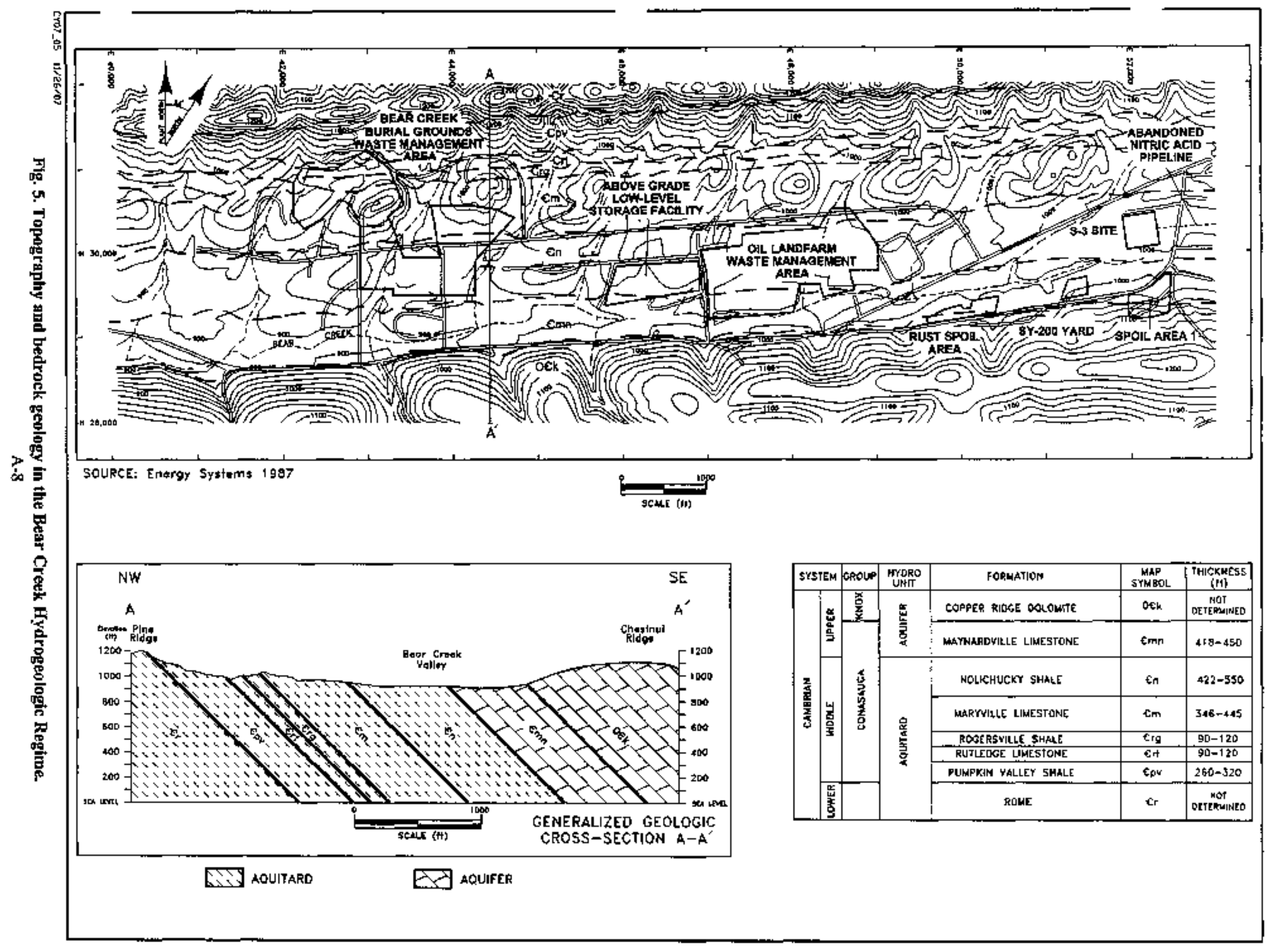




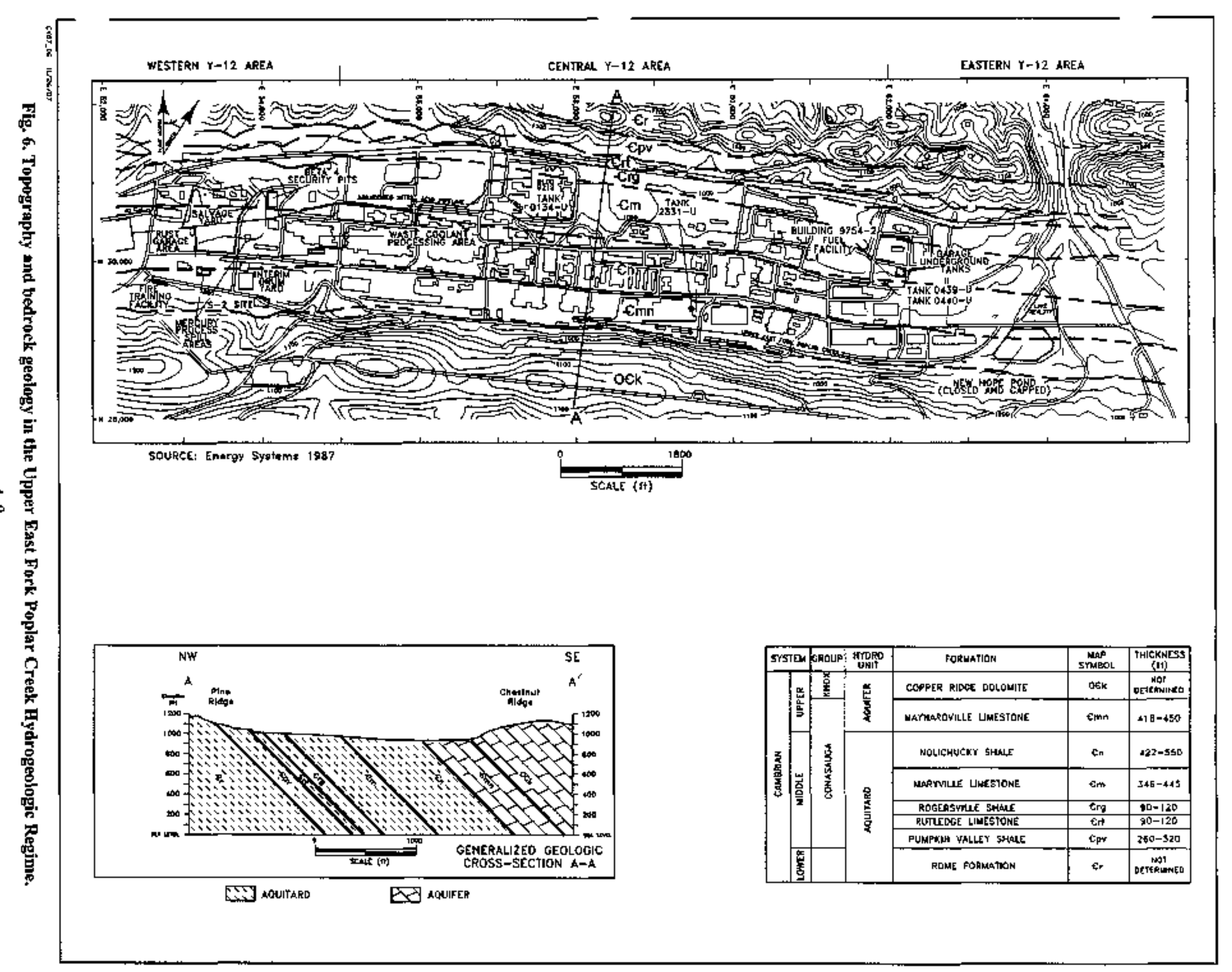




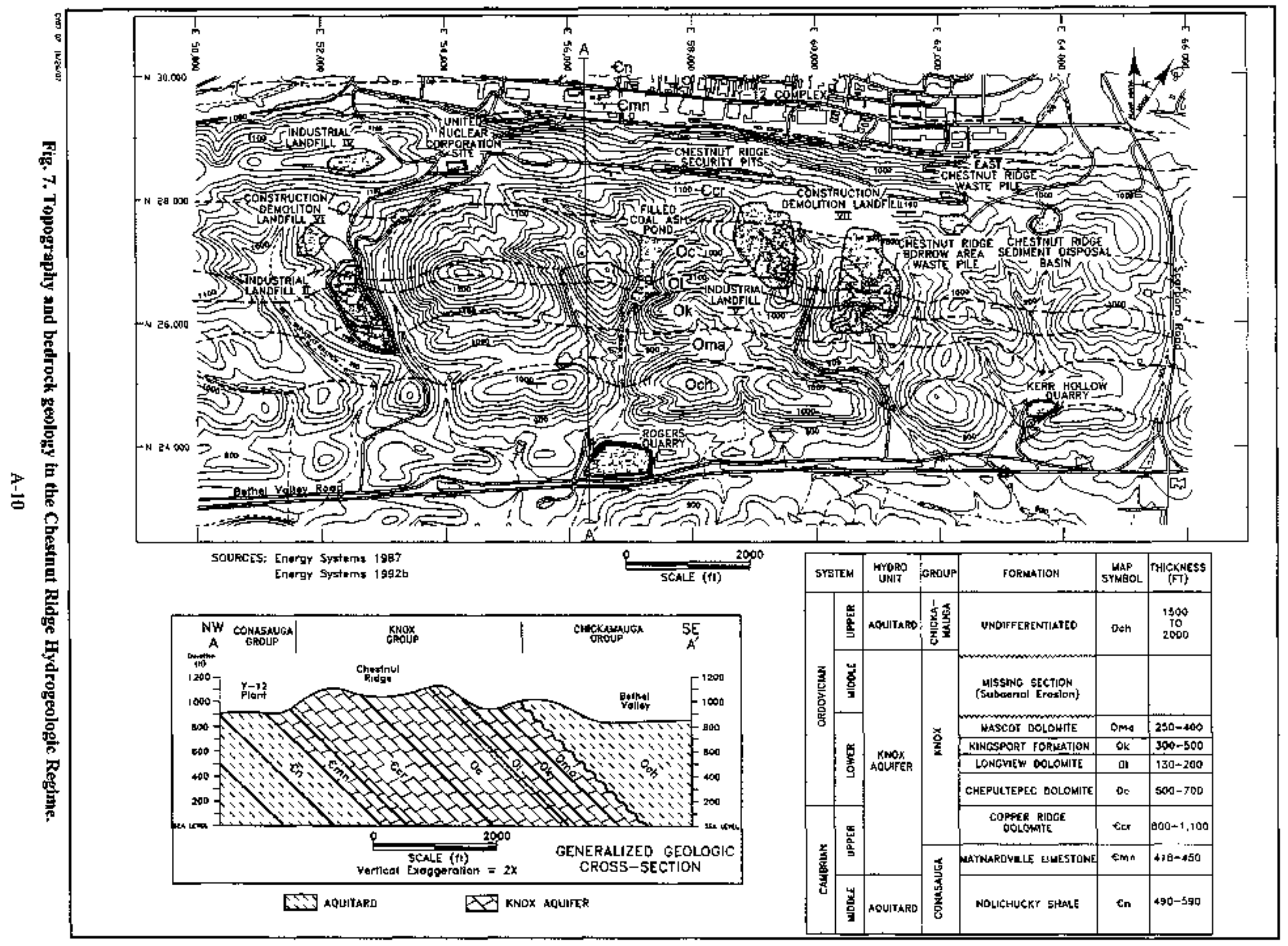




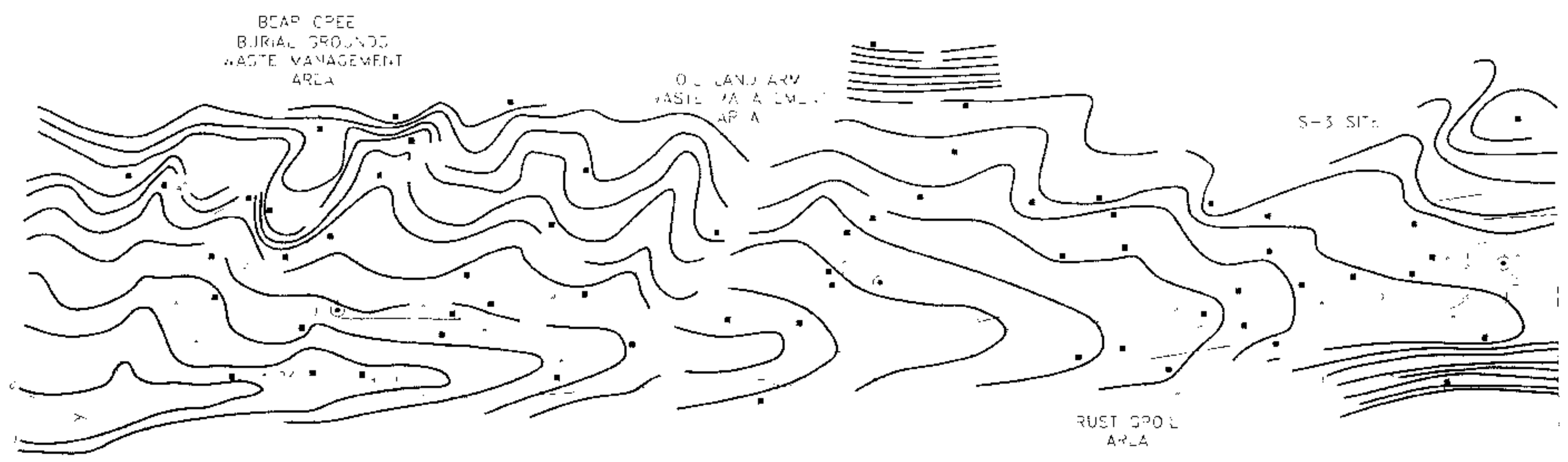

Note Plurre boundarf wells are lucaled about 5 o0o feet west of map area

GROUNDWATER ELEVATIONS APRIL 5172007

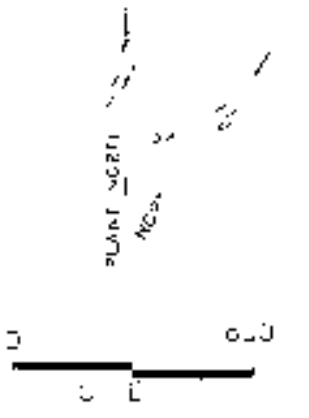

EXP!ANATION 

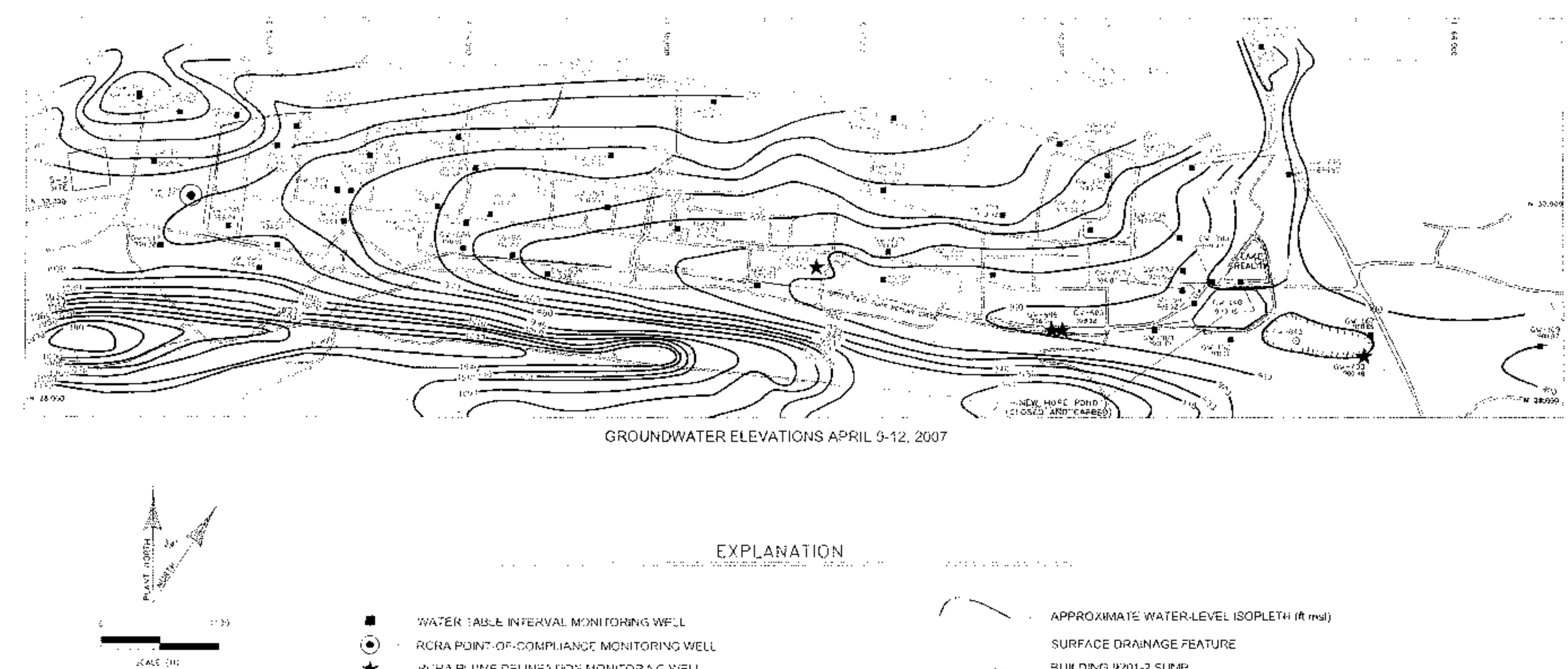

EXPLAMATION

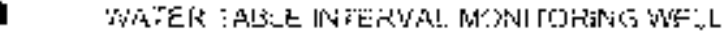

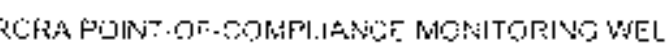

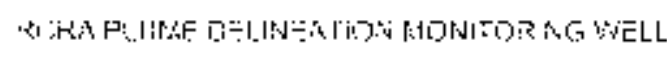

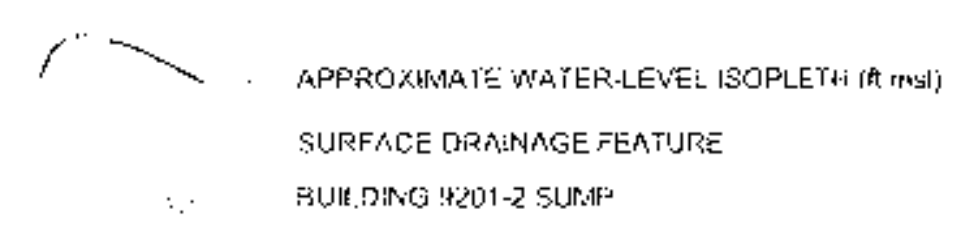

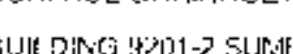

EXTRACATION WEELI.IAND APPROXIMA-:

ZONE OF INFLUENCH 


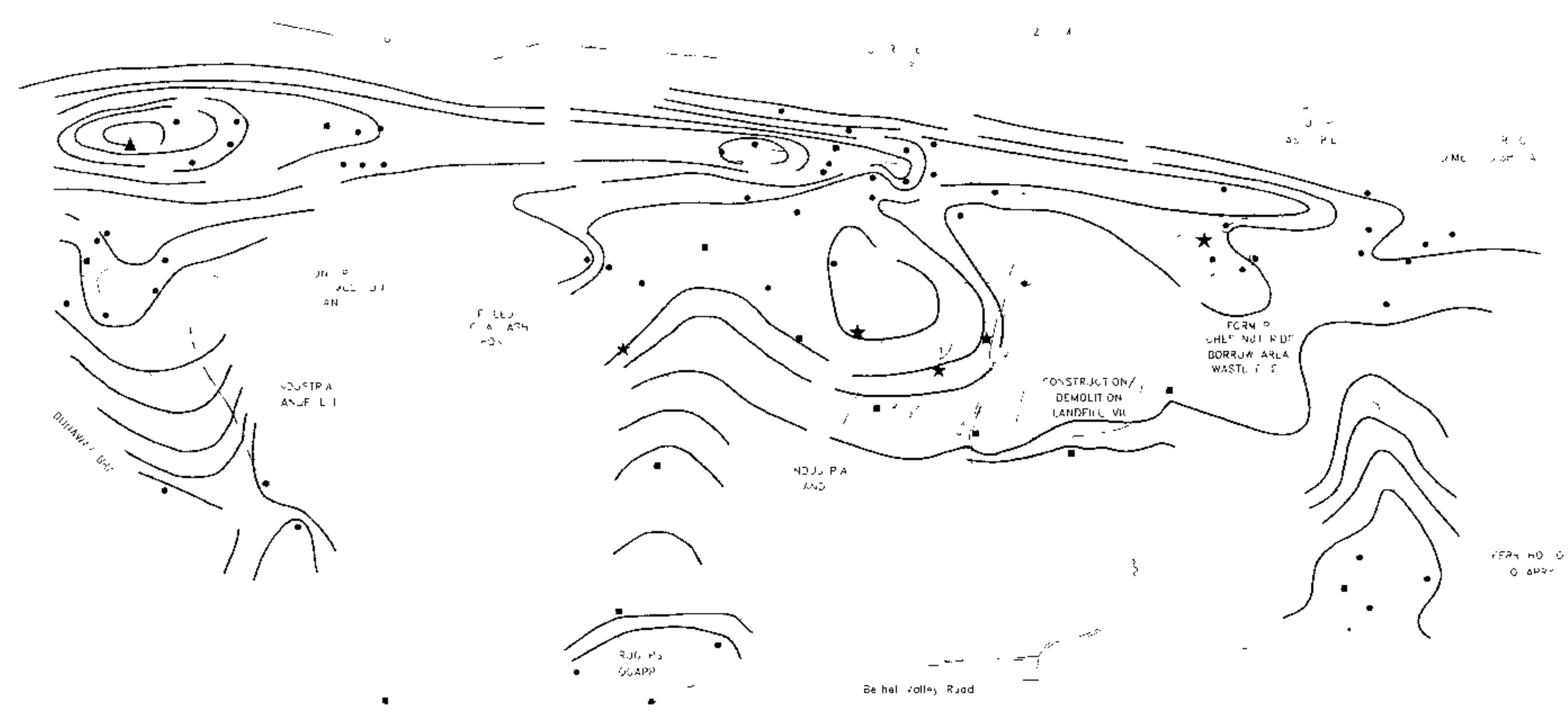

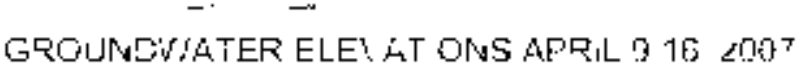

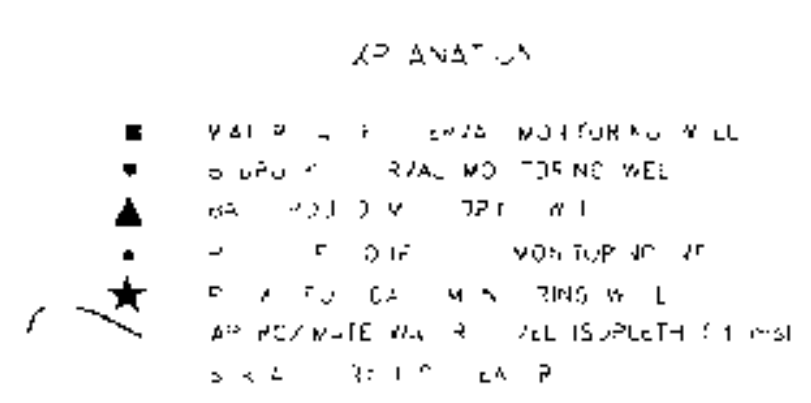

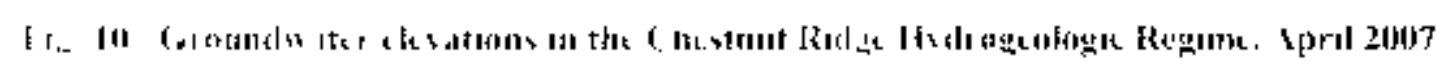



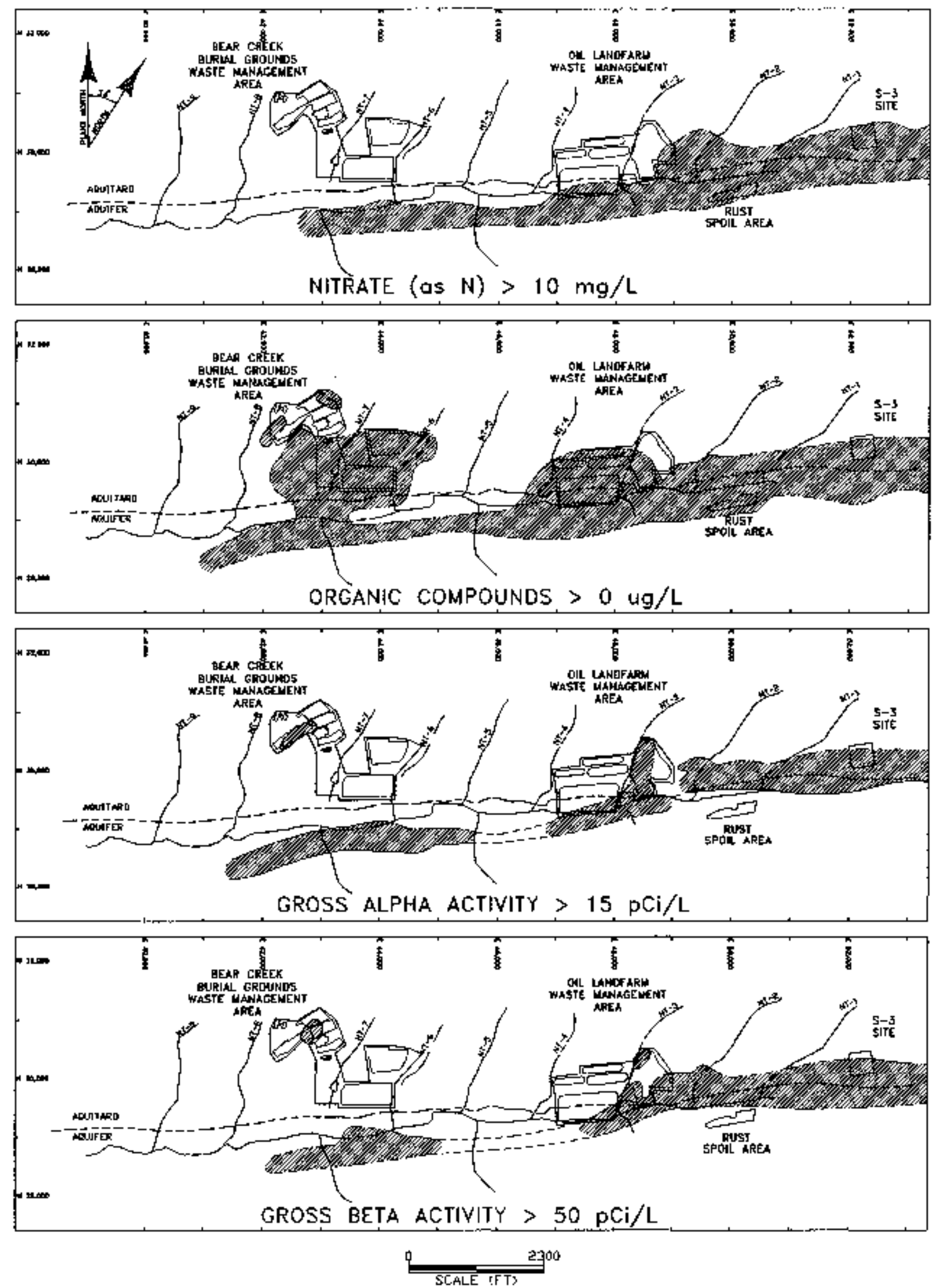

Fig. 11 . Generalized extent of groundwater contamination in the Bear Creek Hydrogeologic Regime. 

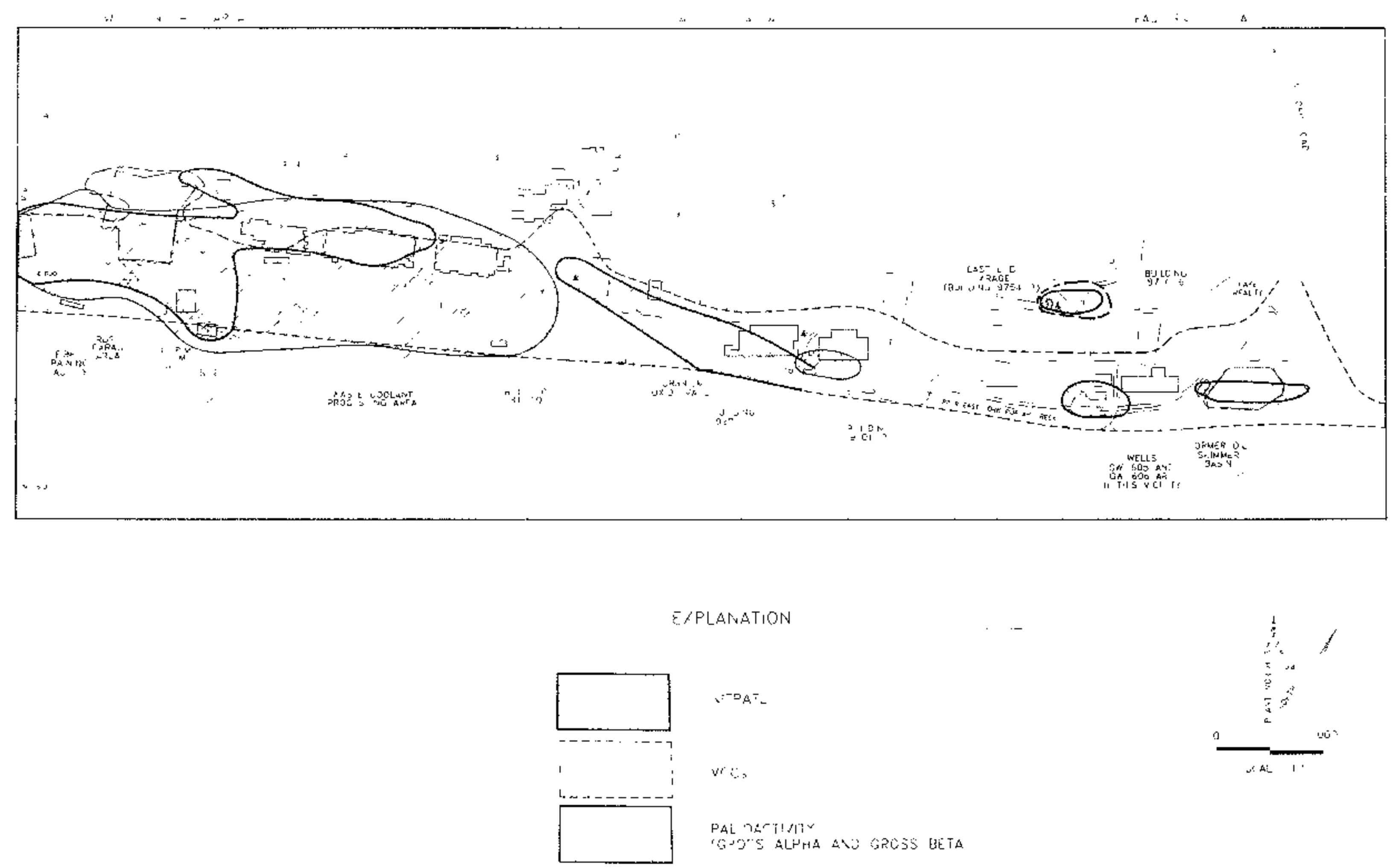


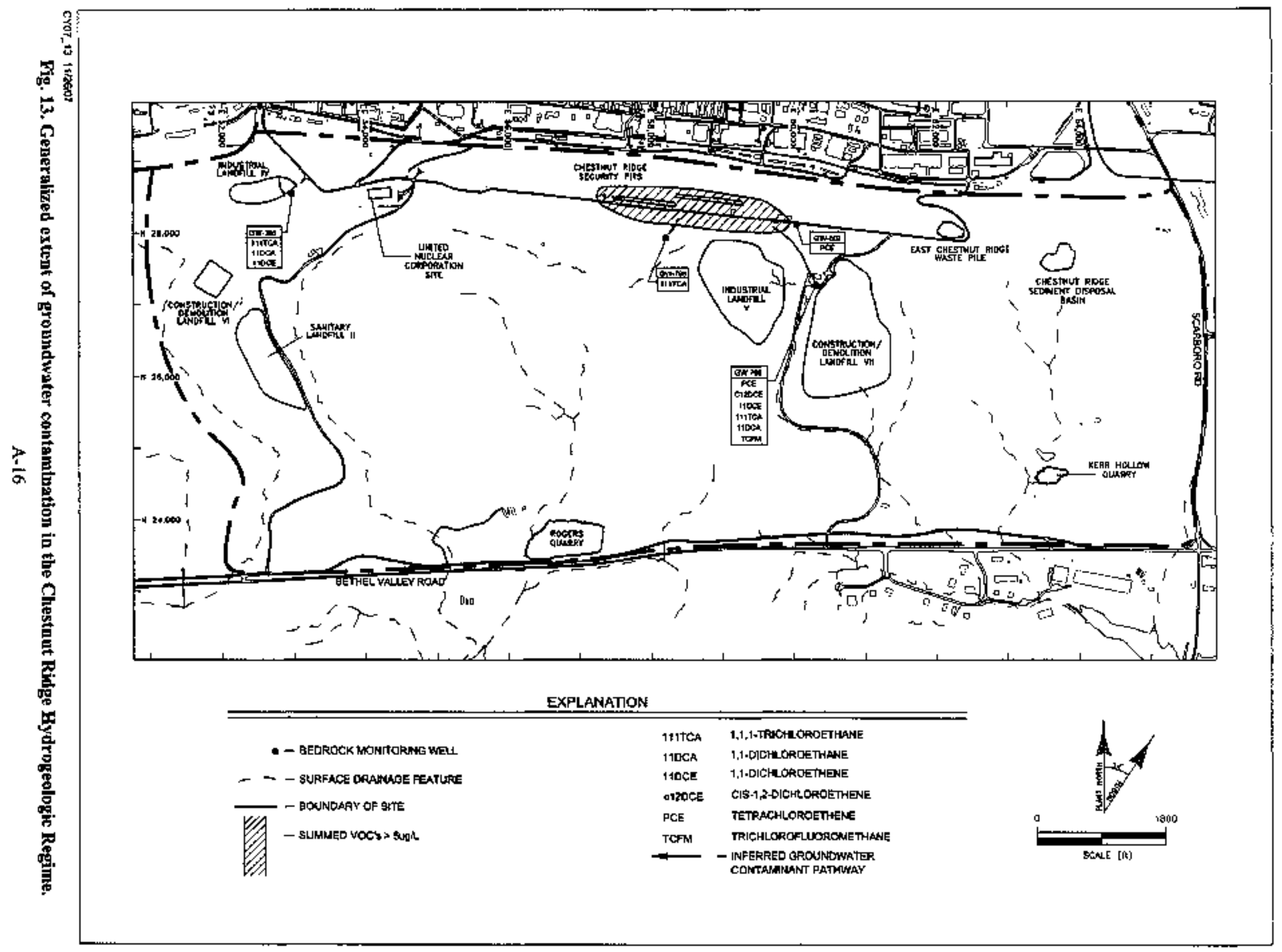




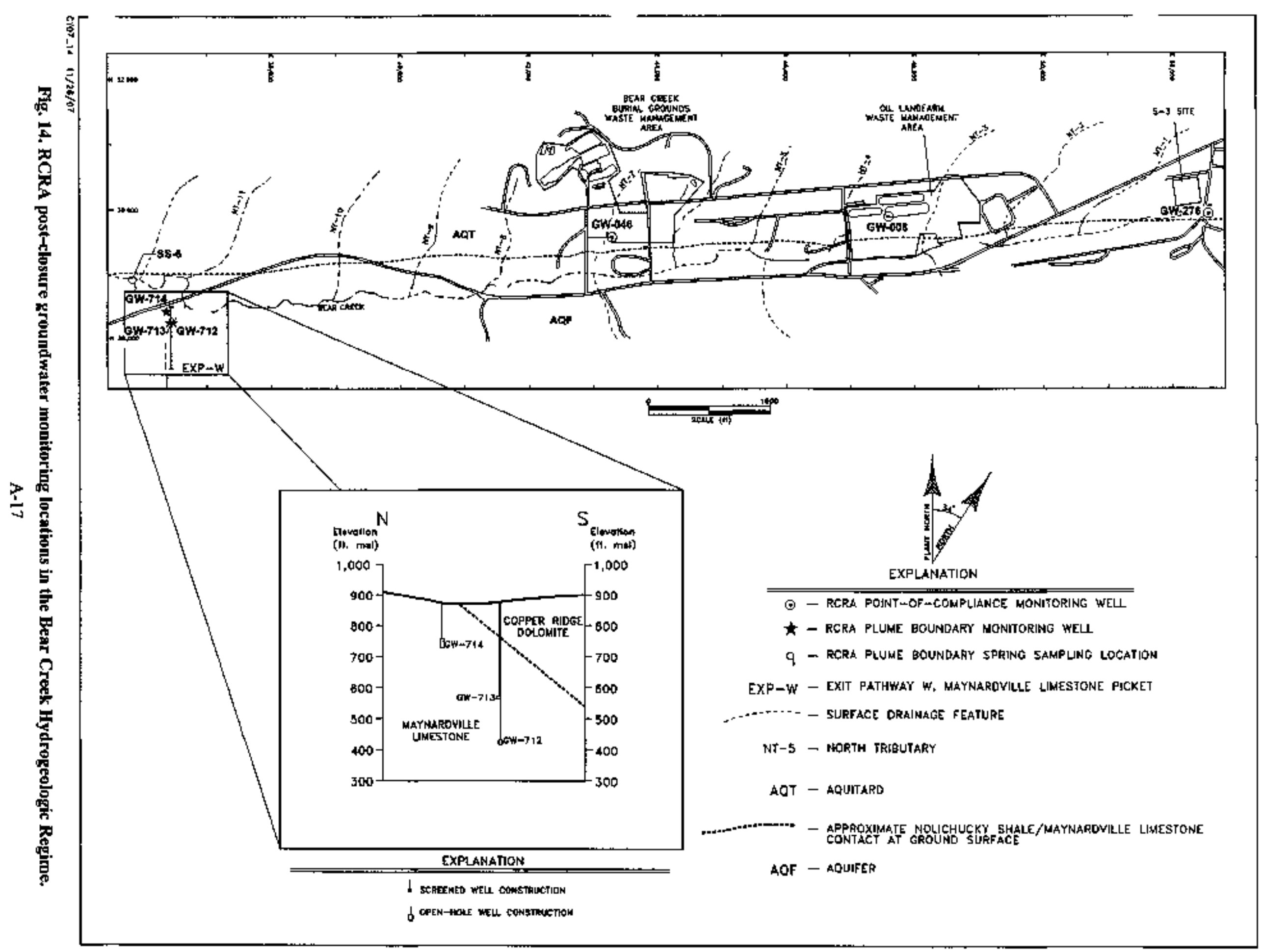




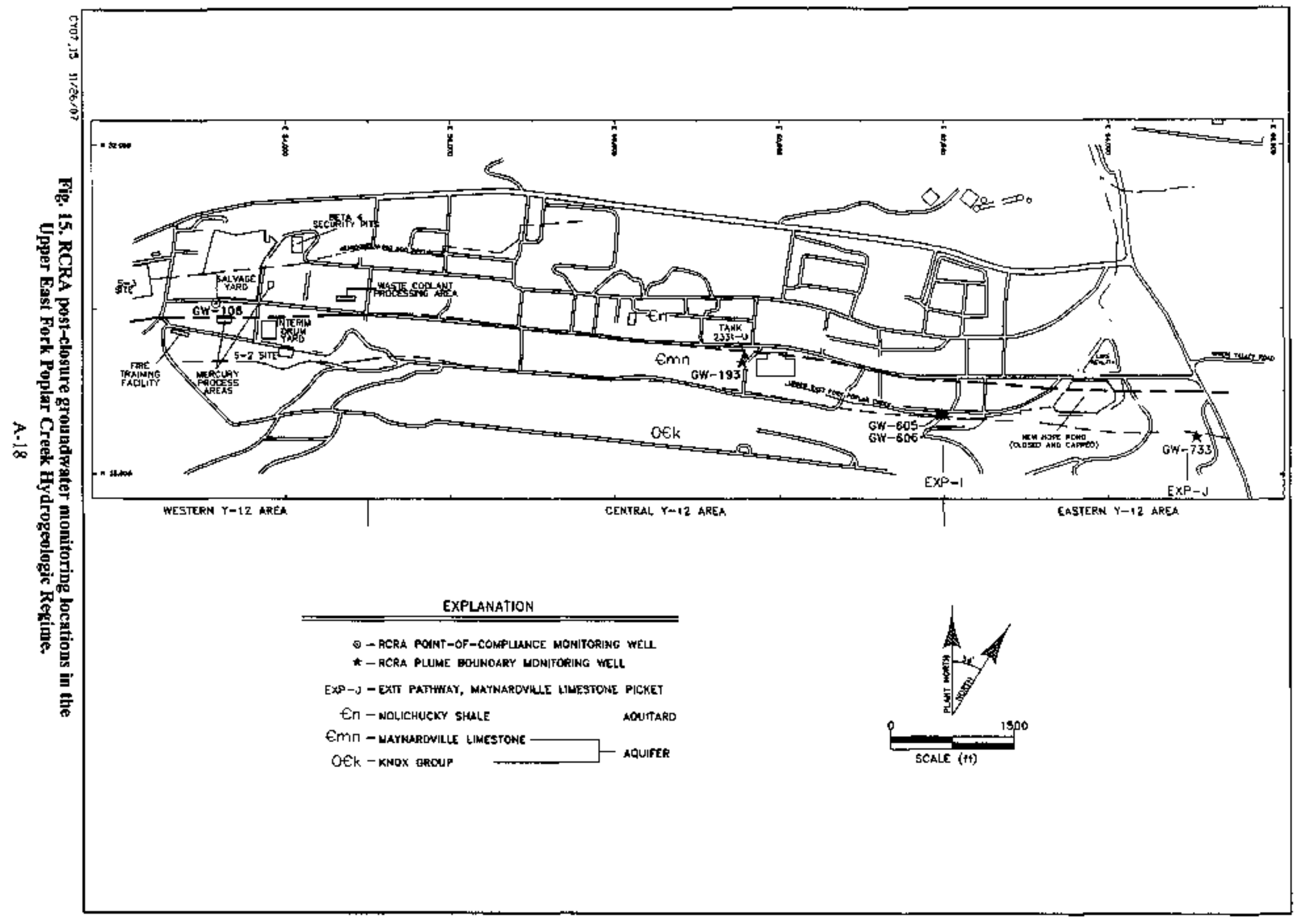




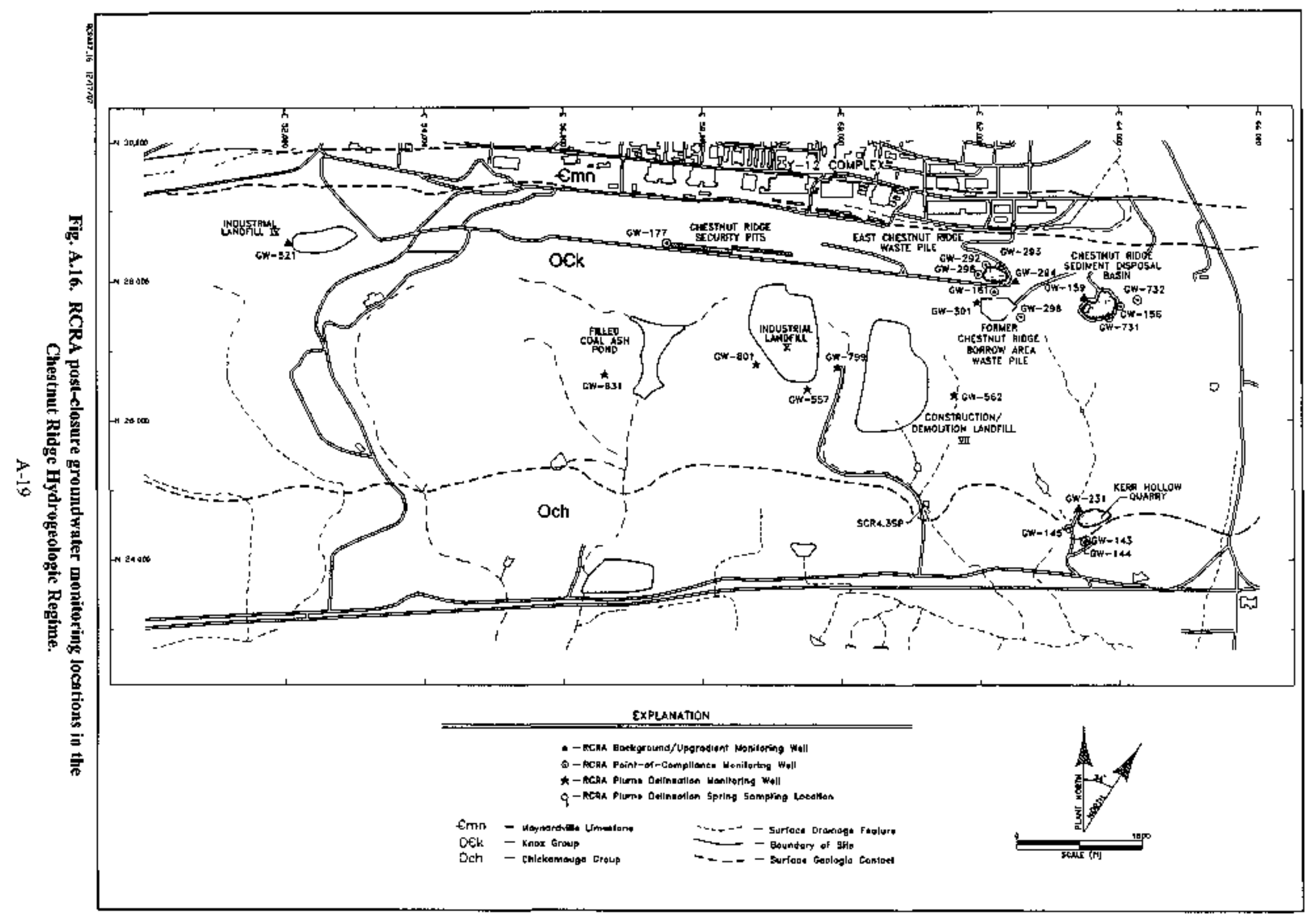



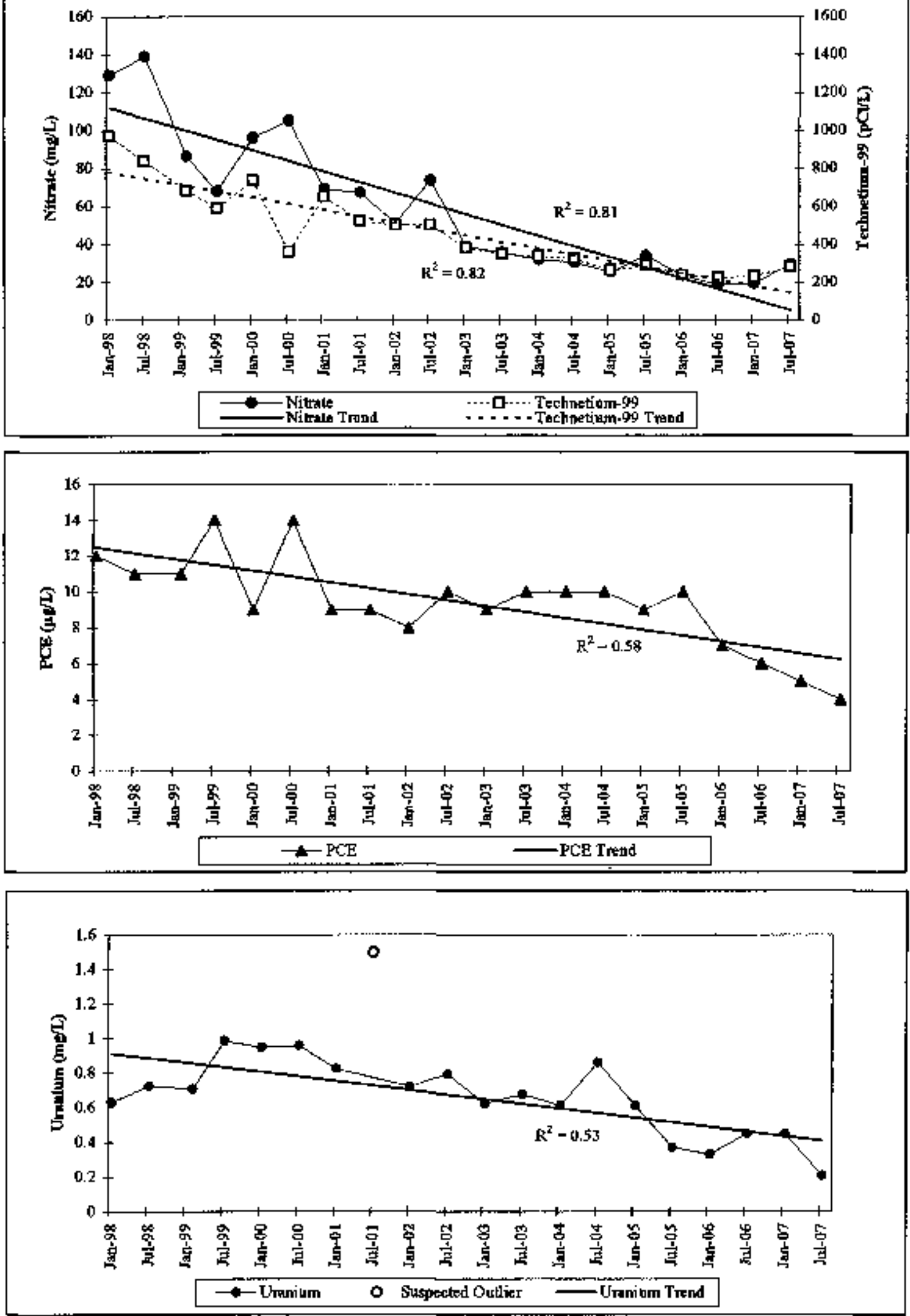

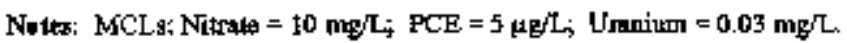

Fig. 17. Nitrate, Tc-99, PCE, and uranlum concentration trends at S-3 Site point-of-compliance wel GW-276. 

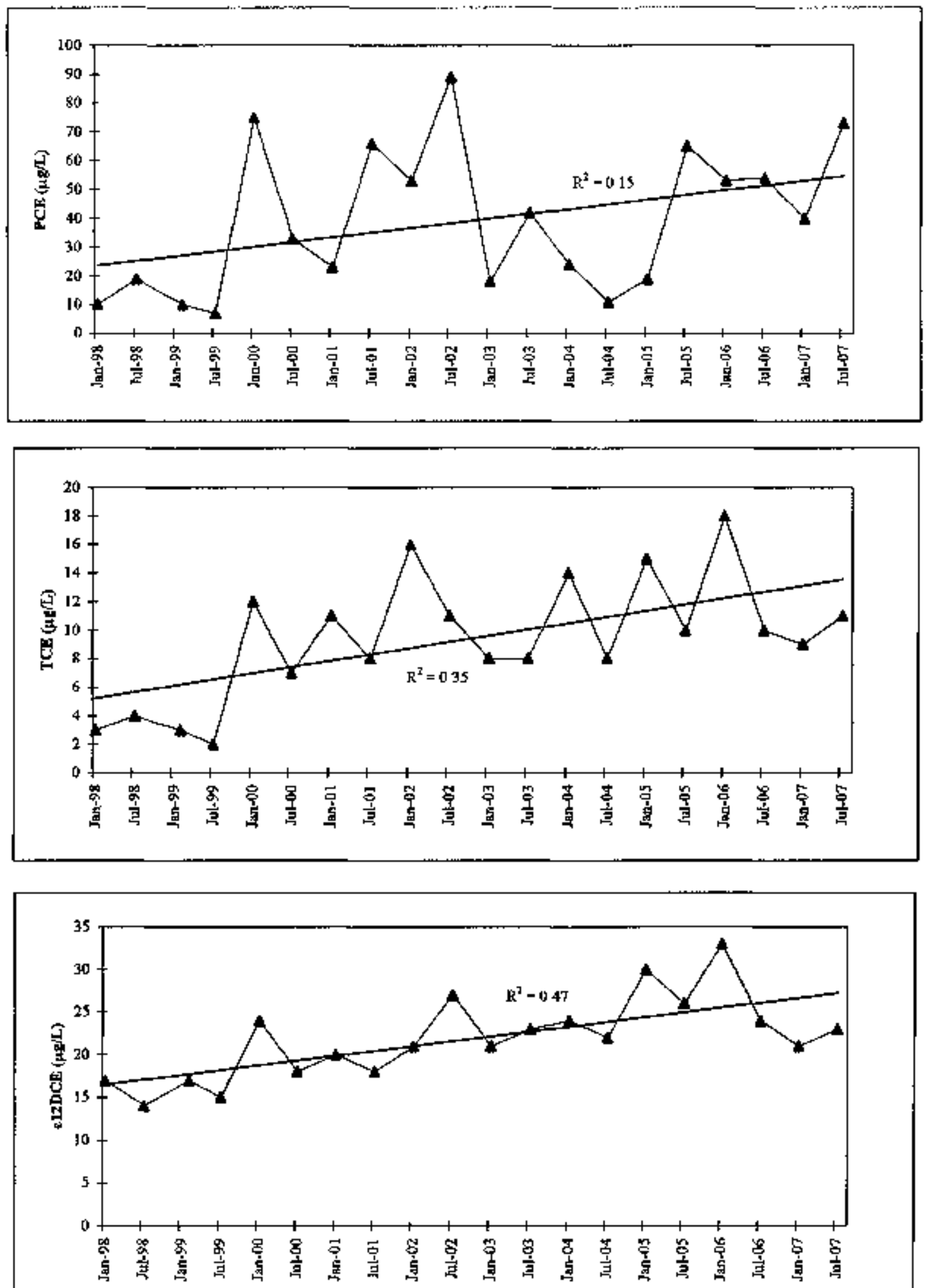

Notes MCLs PCE and TCE $=5 \mu \mathrm{g} / \mathrm{L}, \operatorname{cl} 2 \mathrm{DCE}=\tau 0 \mu \mathrm{g} / \mathrm{L}$

Fig. 18. PCE, TCE, and c12DCE concentration trends at Oil Landfanm joint-of-compliance well GW-008. 

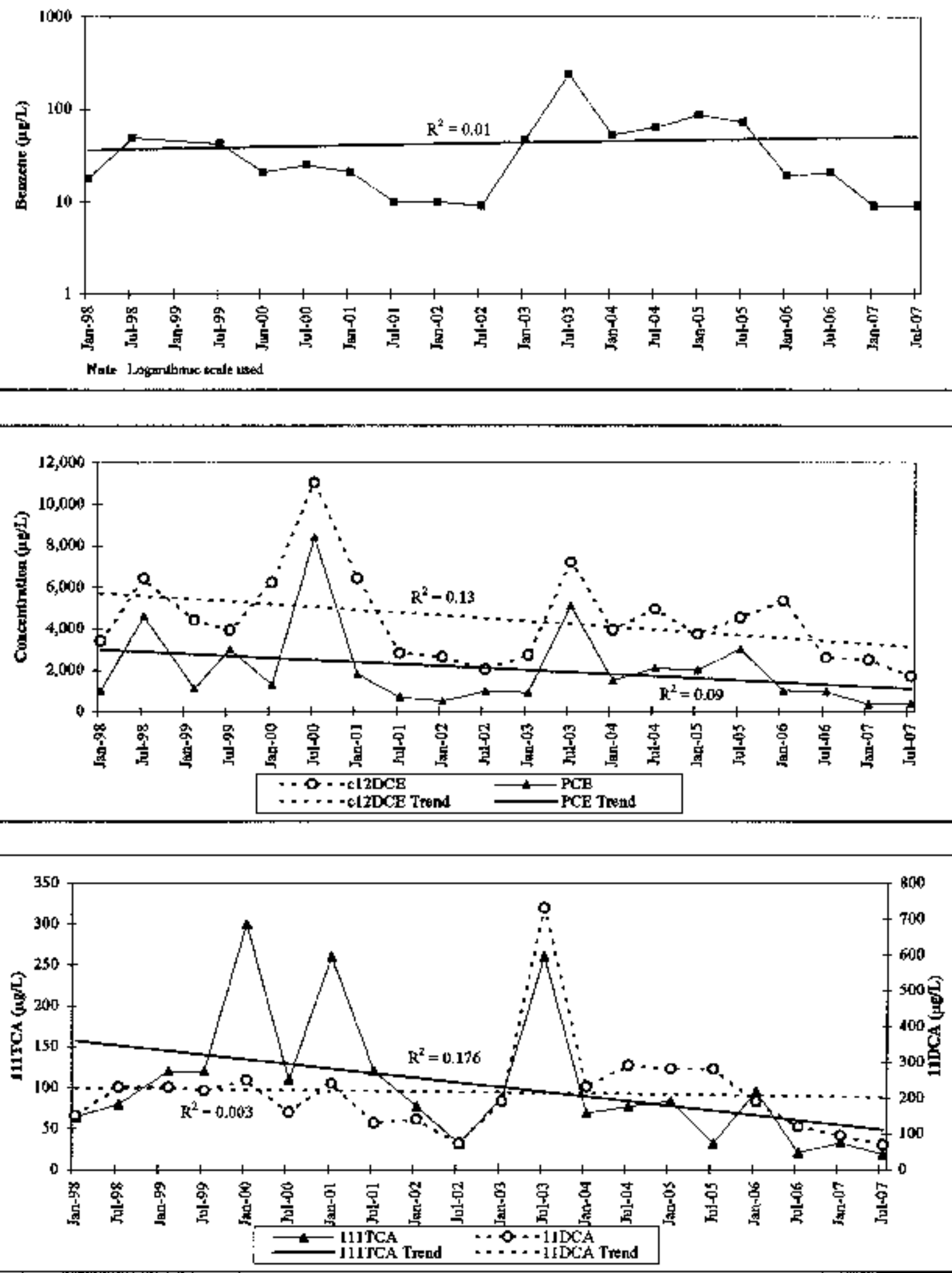

Notes: MCLs: Betnzete atrd PCE = $3 \mu g / \mathrm{L}$; cl2DCE $=70 \mu g / \mathrm{L} ; 111 \mathrm{TCA}=200 \mu \mathrm{g} / \mathrm{l}$; IDCA = not aqplicable.

Fig. 19. Concentrafion trends for selected VOCs at Bear Creek Burial Gronnds' Walk-in Pits point-of-compliance well GW-046. 

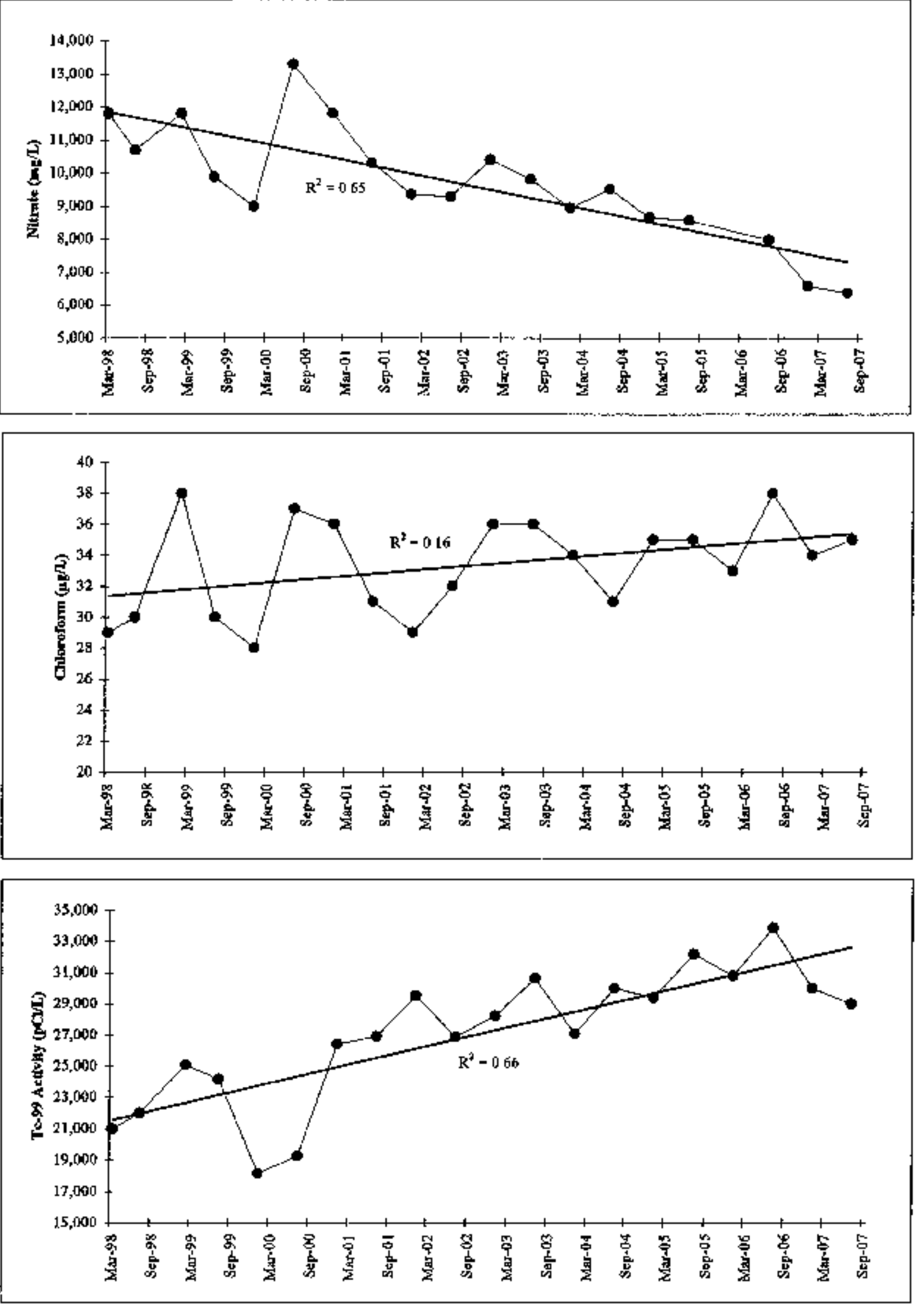

Fig. 20. Nitrate, chloroform, and Te-99 concentration trends at Easter'n S-3 Site Plame point-of-complance well GW-108. 

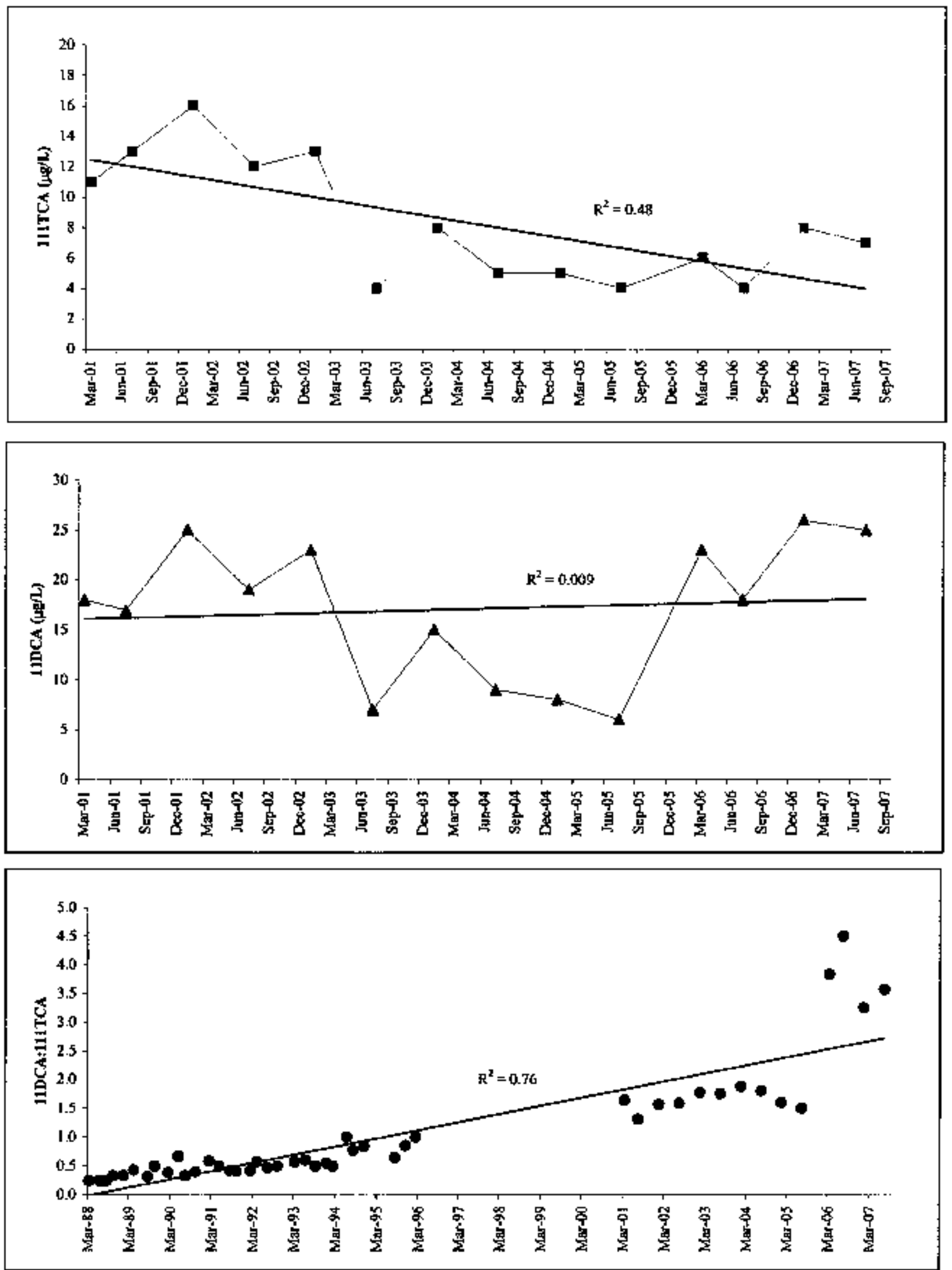

Note: $\mathrm{MiCL}$ for I11 TCA o $200 \mathrm{\mu g} / \mathrm{L}$

Resulta for 31 ITCA that are $<5 \mu \mathrm{g} / \mathrm{L}$, are cstirnater values

Fig. 21. 111TCA and I1DCE concentration trends at Chestnut Ridge Security Pits point-of-compliance well GW-177. 

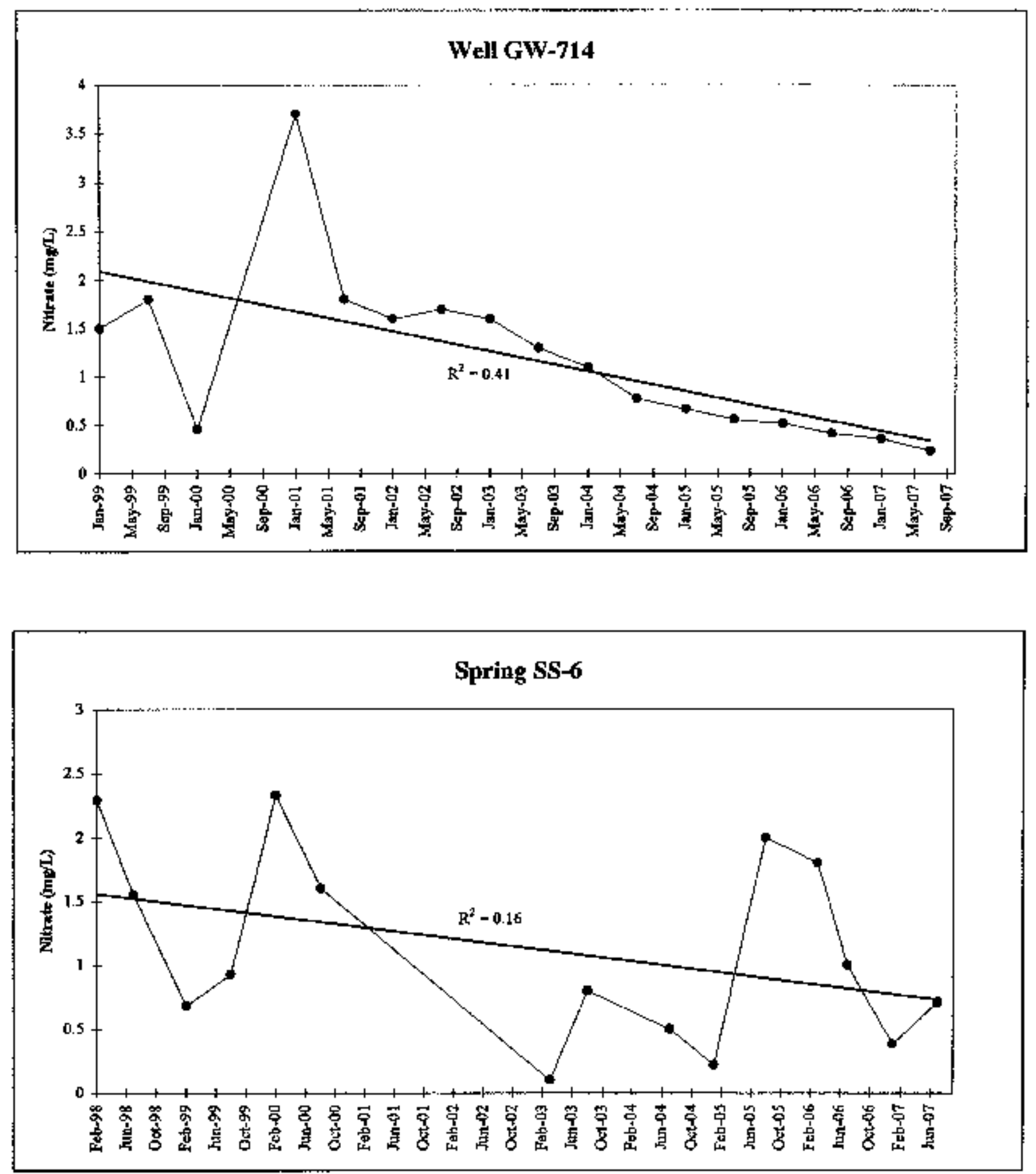

Notes: Ooly results that meet DQOs are plolted; nitrate $\mathrm{MCL}=10 \mathrm{mg} / \mathrm{L}$.

Fig. 22. Nitrate concentsation trends at RCRA plume bonndary well GW-714 and spring SS-6. 


\section{APPENDIX B}

TABLES 


\section{TABLES}

1 Index of RCRA post-closure permit conditions for groundwatto monitoring in the

Bear Creck Hydroyeologic Regime

2 Index of RCRA post-clasure permit conditions for groundwater monitoring in the Upper East Fork Poplar Creek Hydrogeologic Regime

3 Index of RCRA post-closure permit conditions for groundwater monitoring in the

Chestrut Ridge Hydrogeologic Regime

4 Waste maragement sites and RCRA-tegulated units in the Bear Creek

Hydrogeologic Regime.

5 Sources of groundwater contaminant signatures in the Upper East Fork Poplar Creek

Hydrogeologic Regime.

6 Waste management sites and RCRA-regulated units in the Chestrut Ridge

Hydrogeologic Regime

7 Construction details for RCRA groundwater monitoring wells at the V-12 National Security Complex

8 Field measurements and RCRA groundwater target compounds for the S-3 Site, Oil Landfarm, and Bear Creek Burial Grounds/Walk-In Pits

9 Field measurements and RCRA groundwater target compotnds for the Eastem S-3 Site Plume.

10 Field measurements and RCRA groundwater target compounds for the Chestnut Ridge Security Pits, Chestnut Ridge Sediment Disposal Basin, Kerr Hollow Quarry, and East Chestrut Ridge Waste Pile

11 Laboratory blanks and trip blanks associated with CY 2007 RCRA post-closure groundwater monitoring at the Y-12 National Security Complex

12 Volatile organic compounds detected in the laboratory blanks and trip blanks associated with CY 2007 RCRA post-closure groundwater monitoring at the Y-12 National Security Complex.

13 Depth-to-water measurements and groundwater elevations for selected wclls in the Bear Creek Hydrogeologic Regime, April 2007.

14 Depth-to-water measurements and groundwater elevations for selected wells in the Upper East Fork Poplar Creek Hydrogeologic Regime, April 2007

15 Depth-to-water measurements and groundwater elevations for selected wells in the Chestnut Ridge Hydrogeologic Regime, April 2007.

16 CY 2007 leachate sampling results for the East Chestnut Ridge Waste Pile B-39 
This page intentionally left blank.

B-4 
Table 1. Index of RCRA post-closure permit conditiens for groundwater monitoring in the Bear Creek Hydrogeologic Regime

\begin{tabular}{|c|c|c|c|c|}
\hline \multicolumn{4}{|c|}{ Section(s) of RCRA Annual Monitoring } & Report \\
\hline \multirow{2}{*}{$\begin{array}{l}\text { Monittoring } \\
\text { Requirement }\end{array}$} & \multicolumn{3}{|c|}{ Post-Closure Permit Condition/Attachment' } & \\
\hline & S-3 Site & Oil Landfarm & $\begin{array}{c}\text { Barial Grournds } f \\
\text { Watk-In Pits }\end{array}$ & \\
\hline Groundwater Monitoring System & IV.C & V.C & VI.C & 4. \\
\hline Point-of-Compliance Wells & N.C.1(a) & IV.C.1(b) & N.C.1(c) & 4.1 .1 \\
\hline Plume Boundary Wells & IV.C.2 & IV.C.2 & IV.C.2 & 4.1 .1 \\
\hline Sampling and Analysis & TV.E & IV.E & ГV].E & 4. \\
\hline Sampling Frequency & IV,D,1(a),(d) & IV.D.1(b),(d) & IV.D.1(c),(d) & 4.1 .1 \\
\hline Sample Collection & $\begin{array}{l}\text { IV.D. } 2(\mathrm{a}) \\
\text { Attach. } 7, \text { Seet. A }\end{array}$ & $\begin{array}{l}\text { IV.D.2(a) } \\
\text { Attach. } 7, \text { Sect. A }\end{array}$ & $\begin{array}{l}\text { IV.D.2(a) } \\
\text { Attach. 7, Sect. A }\end{array}$ & 4.2 \\
\hline Sample Containers and Preservation & TV.D. $2(\mathrm{~b})$ & IV.D.2(b) & IV.D.2(b) & 4.3 \\
\hline Sample Transportation & IV.D.2(c) & W.D.2(c) & IV.D.2(c) & 4.3 \\
\hline Sample Chain-of-Custody Control & IV.D.2(d) & IV.D.2(d) & IV.D.2(d) & 4.3 \\
\hline $\begin{array}{r}\text { Laboratory Analytes } \\
\text { (RCRA groundwater target constipients) } \\
\text { (RCRA plume boundary constiments) }\end{array}$ & $\begin{array}{l}\text { ГV.D. } 3(\mathrm{a}),(\mathrm{d}) \\
\text { Attach. } 7, \text { Sect. G } \\
\text { Attach. } 7 \text {, Sect. J }\end{array}$ & $\begin{array}{l}\text { W.D.3(b),(d) } \\
\text { Attach. 7, Sect. H } \\
\text { Attech. 7, Sect. J }\end{array}$ & $\begin{array}{l}\text { WD.3(c),(d) } \\
\text { Attach.7, Sect. I } \\
\text { Attach. 7, Sect. J }\end{array}$ & 4.3 .1 \\
\hline Analytical Methods & $\begin{array}{l}\text { I.D.9(a) and } \\
\text { IV.D.4 }\end{array}$ & $\begin{array}{l}\text { I.D.9(a) and } \\
\text { IV.D.4 }\end{array}$ & $\begin{array}{l}\text { I.D.9.(a) and } \\
\text { IV.D.4 }\end{array}$ & 4.3 \\
\hline Gronndwater Surface Elevation & IV.E & IV.E & IV.E & 4.3 .1 \\
\hline Monitoring Data Evaluation & IV,F & IV.F & IV.F & 5. \\
\hline Groundwater Flow Rate and Direction & IV.F.1(e) & IV.F.1(e) & IV.F.l(e) & 5.1 .1 \\
\hline $\begin{array}{r}\text { Point-of-Compliance Concentration } \\
\text { Data }\end{array}$ & IV.F.1(a) & IV.F.1(b) & IV.F.1(c) & $\begin{array}{l}5.2 .1 \\
5.2 .2 \\
5.2 .3 \\
\end{array}$ \\
\hline Plune Boundary Concentration Date & IV.F.1(d) & IV.F.1(d) & IV.F.l(d) & 5.3 .1 \\
\hline Annugl Reporting & J.D. $11(\mathrm{~g})$ & I.D., $1(g)$ & I.D. $11(\mathrm{~g})$ & 1. \\
\hline Signed Certification Statement & II.E.3(d) & П.E.3(d) & IL.E.3(d) & Pg.jx \\
\hline RCRA Facility Information & II.E.3(a) & II.E.3(a) & II.E.3(a) & Pg. ix \\
\hline $\begin{array}{r}\text { Groundwater Monitoring Data } \\
\text { (September } 1 \text { Deadline) } \\
\text { (March } 1 \text { Deadline) }\end{array}$ & $\begin{array}{l}\text { U.E.3(c) } \\
\text { ГV.G.2 } \\
\text { IV.G.4 }\end{array}$ & $\begin{array}{l}\text { II.E.3(c) } \\
\text { JV.G.2 } \\
\text { IV.G.4 }\end{array}$ & $\begin{array}{l}\text { II.E.3(c) } \\
\text { IV.G.2 } \\
\text { IV.G.4 }\end{array}$ & App. C \\
\hline
\end{tabular}

Note: 1. Tennessee Department of Environment and Conservation permit no. TNHW-116 
Table 2. Index of RCRA post-closure permit conditions for groundwater monitering in the Upper East Fork Poplar Creek Hydrogeologic Regime

\begin{tabular}{|c|c|c|}
\hline $\begin{array}{l}\text { Manitoring } \\
\text { Requirement }\end{array}$ & $\begin{array}{c}\text { Post-Closure Permit } \\
\text { Condition/Attachment }\end{array}$ & $\begin{array}{c}\text { Section(s) of RCRA } \\
\text { Annual Monitoring Report }\end{array}$ \\
\hline Groundwater Monitoring System & ГV.C & 4. \\
\hline Point-of-Compliance Wells & IV.C.1 & 4.1 .2 \\
\hline Plume Boundary Wells & IV.C.2 & 4.1 .2 \\
\hline Sampling and Analysis & IV.E & 4. \\
\hline Sampling Frequency & [V.D.] & 4.1 .2 \\
\hline Sample Collection & $\begin{array}{c}\text { IV.D.2(a) } \\
\text { Attach. 6, Sect D }\end{array}$ & 4.2 \\
\hline Sample Containers and Preservation & IV.D.2(b) & 4.3 \\
\hline Sarnple Transportation & IV.D.2(c) & 4.3 \\
\hline Sample Chain-of-Custody Control & TV.D.2(d) & 4.3 \\
\hline $\begin{array}{r}\text { Laboratory Analytes } \\
\text { (RCRA groundwater taget constituents) } \\
\text { (RCRA plume boundary constituents) }\end{array}$ & $\begin{array}{l}\text { IV.D.3 } \\
\text { Attach. } 7, \text { Sect. G } \\
\text { Attach. } 7, \text { Sect. H }\end{array}$ & 4.3 .2 \\
\hline Analyticsl Methods & IV.D.4 and I.D.9(a) & 4.3 \\
\hline Groundwater Surface Elevation & IV,E & 4.3 .2 \\
\hline Monitoring Data Evaluation & IV.F & 5. \\
\hline Groundwater Flow Direction and Ralc & IV.F.1(c) & 5.1 .1 \\
\hline Point-of-Compliance Data & IV.F.1(a) & 5.2 .4 \\
\hline Plume Boundary Data & IV.F.1(b) & $5.3+2$ \\
\hline Annual Reporting & I.D.1 $1(\mathrm{~g})$ & 1. \\
\hline Signed Certification Statement & 11.E.3(d) & Page ix \\
\hline RCRA Facility Information & II.E.3(a) & Page ix \\
\hline $\begin{array}{r}\text { Groundwater Monitoring Data } \\
\text { (September 1 Deadline) } \\
\text { (March } 1 \text { Deadline) }\end{array}$ & $\begin{array}{l}\text { II.E.3(c) } \\
\text { IV.G.2 } \\
\text { IV.G.4 }\end{array}$ & Appendix D \\
\hline
\end{tabular}

Note: 1. Tennessee Department of Environment and Conseryation permit no. TNHW-I13 
Table 3. Index of RCRA post-elosore permit conditions for groundwater monitoring in the Chestmut Ridge Hydrogenlogic Regime

\begin{tabular}{|c|c|c|c|c|c|}
\hline \multirow{3}{*}{ Requirements } & \multicolumn{5}{|c|}{ Sertion of Annual RCRA Monjtoring Report } \\
\hline & \multicolumn{4}{|c|}{ Post-Chosure Permit Condition/Attachment' } & \\
\hline & CRSP & CRSDB & ECRWP & $\mathbf{K H Q}$ & \\
\hline Groundwater Monitoring Program & $\begin{array}{l}\text { IV.F.3.(b); } \\
\text { Attach. 7.3, } \\
\text { Sect 7.3.3 }\end{array}$ & $\begin{array}{l}\text { IV.F.3.(a); } \\
\text { Attach. 7.3, } \\
\text { Sect. 7.3.2 }\end{array}$ & $\begin{array}{l}\text { JV.F.3.(a); } \\
\text { Attach 7.3, } \\
\text { Sect 7.3.2 }\end{array}$ & $\begin{array}{l}\text { IV.F.3.(a); } \\
\text { Attach 7.3, } \\
\text { Sect. 7.3.2 }\end{array}$ & \\
\hline Groundwater Monitoring Network & $\begin{array}{c}\text { IV.B.1 } \\
\text { Altach. } 7.2\end{array}$ & $\begin{array}{c}\text { IV.B.] } \\
\text { Attach } 7.2\end{array}$ & $\begin{array}{c}\text { JV.B.] } \\
\text { Attach. } 7.2\end{array}$ & $\begin{array}{c}\text { JV.B.] } \\
\text { Attach. } 7.2\end{array}$ & 4. \\
\hline Upgradient/Background Wells & $\begin{array}{c}\text { Attach } 73 \\
\text { Sect. } 7.3 .4 \& \\
\text { Table } 7.3-1\end{array}$ & $\begin{array}{c}\text { Attach. 7.3, } \\
\text { Sect. } 7.3 .4 \& \\
\text { Table } 7.3-1\end{array}$ & $\begin{array}{c}\text { Attach. 7.3, } \\
\text { Sect. 7.3.4 \& } \\
\text { Table 7.3-1 }\end{array}$ & $\begin{array}{c}\text { Attach. } 7.3 \\
\text { Sect. } 7.3 .4 \& \\
\text { Table 7.3-1 }\end{array}$ & $\begin{array}{l}4.1 .3 \\
4.1 .4 \\
4.1 .5 \\
4.1 .6 \\
\end{array}$ \\
\hline Point-of-Compliance Wells & $\begin{array}{r}\text { Attacb. 7.3, } \\
\text { Sect. 7.3.4 \& } \\
\text { Table 7.3-1 }\end{array}$ & $\begin{array}{r}\text { Atlach. 7.3, } \\
\text { Sect. 7.3.4 \& } \\
\text { Table 7.3-1 }\end{array}$ & $\begin{array}{c}\text { Attach. } 7.3, \\
\text { Sect } 7.3 .4 \& \\
\text { Table } 7.3-1\end{array}$ & $\begin{array}{r}\text { Attach } 7.3, \\
\text { Sect } 7.3 .4 \& \\
\text { Table } 7.3-1\end{array}$ & $\begin{array}{l}4.1 .3 \\
4.1 .4 \\
4.1 .5 \\
4.1 .6\end{array}$ \\
\hline Plume Boundary Wells & \begin{tabular}{|c|} 
Attach. 7.3 , \\
Sect. $7.3 .4 \&$ \\
Table $7.3-1$
\end{tabular} & NA & NA & NA & 4.1 .3 \\
\hline Well Plugging and Abandonment & $\begin{array}{c}\text { IV.B. } 2 ; \\
\text { Attach. } 6.4\end{array}$ & $\begin{array}{c}\text { IV.B.2; } \\
\text { Attach. } 6.4\end{array}$ & $\begin{array}{c}\text { IV.B.2; } \\
\text { Attach. } 6.4\end{array}$ & $\begin{array}{c}\text { IV.B.2; } \\
\text { Attach. } 6.4\end{array}$ & NA \\
\hline Groundwatcr Sampling and Analysls & \multicolumn{4}{|c|}{ IV,C } & 4 \\
\hline Groundwater Sampling Method & $\begin{array}{c}\text { IV.C.1; } \\
\text { Attach 6.1 }\end{array}$ & $\begin{array}{c}\text { IV.C. } 1 ; \\
\text { Attach. } 6.1\end{array}$ & $\begin{array}{c}\text { IV.C.l; } \\
\text { Attach. 6.] }\end{array}$ & $\begin{array}{c}\text { IV.C.1; } \\
\text { Attach. } 6.1\end{array}$ & 4.2 \\
\hline Surfacc Water Sampling Method & $\begin{array}{c}\text { IVC. } 2 \\
\text { Attach. } 6.2\end{array}$ & NA & NA & NA & 4,2 \\
\hline Sampling Frequency & $\begin{array}{c}\text { Attach } 7.3 \\
\text { Sect. } 7.3 .7\end{array}$ & $\begin{array}{l}\text { Attach. 7.3, } \\
\text { Sect. 7.3.7 }\end{array}$ & $\begin{array}{l}\text { Attach. } 7.3 \\
\text { Sect } 7.3 .7\end{array}$ & $\begin{array}{c}\text { Attach, } 7.3, \\
\text { Sect. } 7.3 .7\end{array}$ & $\begin{array}{l}4.1 .3 \\
4.1 .4 \\
4.1 .5 \\
4.1 .6 \\
\end{array}$ \\
\hline Sample Containers and Preservation: & $\begin{array}{c}\text { IV,C.3; } \\
\text { Attach. } 6.1 \\
\text { Attach } 6.2\end{array}$ & $\begin{array}{c}\text { IVC.3; } \\
\text { Attach 6.1 }\end{array}$ & $\begin{array}{c}\text { IV.C.3; } \\
\text { Aftach. } 6.1\end{array}$ & $\begin{array}{c}\text { IV.C.3; } \\
\text { Attach. 6.1 }\end{array}$ & 4.3 \\
\hline Saruple Transportation & $\begin{array}{c}\text { IV.C. } 4 ; \\
\text { Attach. } 6.1 \\
\text { Attach. } 6.2\end{array}$ & $\begin{array}{c}\text { IV.C. } 4 \\
\text { Attach. } 6.1\end{array}$ & $\begin{array}{c}\text { IV.C.4; } \\
\text { Attacb. 6.1 }\end{array}$ & $\begin{array}{c}\text { IV.C.4; } \\
\text { Attach. 6.1 }\end{array}$ & 4.3 \\
\hline Sample Chain-of-Custody Control & $\begin{array}{c}\text { IV.C.5; } \\
\text { Attach. 6.1 } \\
\text { Attach. } 6.2\end{array}$ & $\begin{array}{c}\text { IV.C.5; } \\
\text { Attach. } 6.1\end{array}$ & $\begin{array}{c}\text { JV.C.5; } \\
\text { Attach. } 6.1\end{array}$ & $\begin{array}{c}\text { IV.C.5; } \\
\text { Attach. 6.1 }\end{array}$ & 4.3 \\
\hline Timeframe for Laboratory Analyses & IV,C.6 & IV,C.6 & IV.C.6 & IV,C.6 & 4.3 \\
\hline Labotatory Analytical Methods & $\begin{array}{c}\text { IV.C.6; } \\
\text { Attach. 6.6; } \\
\text { Attach. 7.3, } \\
\text { Sect. } 7.3 .6\end{array}$ & $\begin{array}{c}\text { IV.C.6; } \\
\text { Attach. } 6.6 ; \\
\text { Attach. } 7.3 \text {, } \\
\text { Sect. } 7.3 .6\end{array}$ & $\begin{array}{c}\text { IV.C.6; } \\
\text { Attach. 6.6; } \\
\text { Attach. 7.3, } \\
\text { Sect. 7.3.6 }\end{array}$ & $\begin{array}{c}\text { IV.C.6; } \\
\text { Attach, 6.6; } \\
\text { Attach. 7.3, } \\
\text { Sect. 7.3.6 }\end{array}$ & 4.3 \\
\hline QAVQ Samping & $\begin{array}{c}\text { IV.C.7; } \\
\text { Attach } 6.6\end{array}$ & $\begin{array}{c}\text { IV.C. } 7 \\
\text { Attach } 6.6\end{array}$ & $\begin{array}{c}\text { IV.C. } 7 \\
\text { Attach. } 6.6\end{array}$ & $\begin{array}{c}\text { IV.C. } 7 \\
\text { Attach 6.6 }\end{array}$ & 4.4 \\
\hline
\end{tabular}


Table 3 (continued)

\begin{tabular}{|c|c|c|c|c|c|}
\hline \multirow{3}{*}{$\begin{array}{l}\text { Monitoring } \\
\text { Requirement }\end{array}$} & \multicolumn{5}{|c|}{ Section of Annusl RCRA Monttoring Report } \\
\hline & \multicolumn{4}{|c|}{ Post-Closure R'ermit Condition/Attachment' } & \\
\hline & CRSP & CRSDB & ECRWP & KHQ & \\
\hline RCRA Gronsdwater Target Compounds & $\begin{array}{c}\text { IV.E.1; } \\
\text { Attach 7.1, } \\
\text { Table 7.1-1; } \\
\text { Attach 7.3, } \\
\text { Sect. 7.3.5 }\end{array}$ & $\begin{array}{c}\text { IV.E.1; } \\
\text { Attach. 7.1, } \\
\text { Table 7.1-1; } \\
\text { Attach. 7.3, } \\
\text { Sect. 7.3.5 }\end{array}$ & $\begin{array}{c}\text { IV.E.1; } \\
\text { Attach 7.1, } \\
\text { Table 7.1-1; } \\
\text { Attach. 7.3, } \\
\text { Sect. 7.3.5 }\end{array}$ & $\begin{array}{c}\text { IV.E. 1; } \\
\text { Attach. 7.1, } \\
\text { Table 7.1-1; } \\
\text { Attach. 7.3, } \\
\text { Sect. 7.3.5 }\end{array}$ & $\begin{array}{l}4.3 .3 \\
4.3 .4 \\
4.3 .5 \\
4.3 .6\end{array}$ \\
\hline Groundwater Surface Elevations & $\begin{array}{c}\text { IV.D } \\
\text { Attach. 6.1 }\end{array}$ & $\begin{array}{c}\text { TV.D } \\
\text { Attach. } 6.1\end{array}$ & $\begin{array}{c}\text { TVD } \\
\text { Attach } 6.1\end{array}$ & $\begin{array}{c}\text { IV.D } \\
\text { Attach. } 6.1\end{array}$ & $\begin{array}{l}4.3 .3 \\
4.3 .4 \\
4.3 .5 \\
4.3 .6\end{array}$ \\
\hline Monttoring Data Eraluation & \multicolumn{4}{|c|}{ IV.F } & 5. \\
\hline Groundwater Flow Direction/Rate & IV.F.1 & IV.F.1 & IV.F.1 & [V.F.] & 5.1 .2 \\
\hline $\begin{array}{r}\text { Point-of-Compliance Concentration } \\
\text { Data }\end{array}$ & $\begin{array}{l}\text { Attach 7.5, } \\
\text { Sect 7.5.3 }\end{array}$ & $\begin{array}{l}\text { Attach 7.4, } \\
\text { Sect 7.4.3 }\end{array}$ & $\begin{array}{l}\text { Attich } 7.4, \\
\text { Sect } 7.4 .3\end{array}$ & $\begin{array}{l}\text { Attach. 7.4, } \\
\text { Sect 7.4.3 }\end{array}$ & $\begin{array}{l}5.2 .5 \\
5.4 .1 \\
5.4 .2 \\
5.4 .3\end{array}$ \\
\hline Plume Boundacy Data & $\begin{array}{l}\text { Attach. } 7.5 \\
\text { Sect. } 7.5 .5\end{array}$ & NA & NA & NA & $5.3 . \overline{3}$ \\
\hline Elevated Concentration Verification & NA & $\begin{array}{l}\text { Attach. } 7.4 \text {, } \\
\text { Sect. 7.4.5 }\end{array}$ & $\begin{array}{l}\text { Attach. } 7.4 \\
\text { Sect. } 7.4 .5\end{array}$ & $\begin{array}{l}\text { Attach } 7.4 \\
\text { Sect. } 7.4 .5\end{array}$ & $\begin{array}{l}5.4 .1 \\
5.4 .2 \\
5.4 .3\end{array}$ \\
\hline $\begin{array}{r}\text { Statistically Sigraficant Concentraţon } \\
\text { Increase }\end{array}$ & NA & $\begin{array}{l}\text { Attach, 7.4, } \\
\text { Sect. 7.4.6 }\end{array}$ & $\begin{array}{l}\text { Attach. } 7.4 \\
\text { Sect. } 7.4 .6\end{array}$ & $\begin{array}{l}\text { Attach } 7.4 \text {, } \\
\text { Sect. } 7.4 .6\end{array}$ & $\begin{array}{l}5.4 .1 \\
5.4 .2 \\
5.4 .3 \\
\end{array}$ \\
\hline Confismation Sampling & NA & $\begin{array}{l}\text { Attach. } 7.4 \\
\text { Soct. } 7.4 .7\end{array}$ & $\begin{array}{l}\text { Attach } 7.4 \\
\text { Sect. } 7.4 .7\end{array}$ & $\begin{array}{l}\text { Attach. } 7.4 \text {, } \\
\text { Sect. } 7.4 .7\end{array}$ & $\begin{array}{l}5.4 .1 \\
5.4 .2 \\
5.4 .3\end{array}$ \\
\hline Annugl Reporting & \multicolumn{4}{|c|}{ M.E; IV.G.4; Attach. 7.3, Sect. 7.3.8 } & 1. \\
\hline Certification Statemen & IL.E.3.(d) & IIE.3.(d) & L.E.3.(d) & LE.3.(d) & $\mathbf{P}_{\mathbf{g}, \mathrm{ix}}$ \\
\hline RCRA Facility Information & II.E.3.(a) & II.E.3,(a) & II.E.3.(a) & M.E.3.(a) & $\mathrm{Pg}, \mathrm{ix}$ \\
\hline $\begin{array}{r}\text { Groumdwater Monitoring Data } \\
\text { (September } 1 \text { Deadline) } \\
\text { (March } 1 \text { Deadline) }\end{array}$ & $\begin{array}{l}\text { Ü.E.3.(c) } \\
\text { IV.G.2 } \\
\text { IV.G.4 }\end{array}$ & $\begin{array}{l}\text { II.E.3.(c) } \\
\text { IV.G.2 } \\
\text { IV.G.4 }\end{array}$ & $\begin{array}{l}\text { II.E.3.(c) } \\
\text { IV.G.2 } \\
\text { IV.G.4 }\end{array}$ & $\begin{array}{l}\text { I.E.3.(c) } \\
\text { IV.G.2 } \\
\text { IV.G.4 }\end{array}$ & App. E \\
\hline Monitoring Data Evaluation & $\begin{array}{c}\text { JV.F.1 } \\
\text { Altach. } 7.3 \\
\text { Sect. } 7.3 .8 \\
\end{array}$ & $\begin{array}{c}\text { IV.F.1 } \\
\text { Attach. } 7.3 \\
\text { Sect. } 7.3 .8 \\
\end{array}$ & $\begin{array}{c}\text { [V.F.1 } \\
\text { Altach. } 7.3 \\
\text { Sect. } 7.3 .8\end{array}$ & $\begin{array}{l}\text { IV.F.1 } \\
\text { Attach. } 7.3 \\
\text { Sect } 7.3 .8\end{array}$ & 5 \\
\hline Leachate Data Summary and Evahuation & NA & NA & $\begin{array}{l}\text { Attach } 7.3 \\
\text { Sect } 7.3 .8\end{array}$ & NA & 6. \\
\hline
\end{tabular}

Note: 1. Tenmessce Department of Environtuent and Conservation permit no. TNHW-128 NA = Not applicable 
Table 4. Waste management sites and RCRA-regalated anits in the Bear Creek Hydrogeologic Regime

\begin{tabular}{|c|c|c|c|c|}
\hline \multirow{2}{*}{$\begin{array}{l}\text { Waste Management Site } / \\
\text { Regulated Unlt }\end{array}$} & \multirow{2}{*}{$\begin{array}{l}\text { Regulatory } \\
\text { Classifteation' }\end{array}$} & \multirow{2}{*}{ General Waste Inventory } & \multicolumn{2}{|c|}{ Operational Status } \\
\hline & & & Closed & Open \\
\hline $\begin{array}{l}\text { Above Grade Low-Level } \\
\text { Storage Facility }\end{array}$ & NR & $\begin{array}{l}\text { Low-level tadioactive construction and } \\
\text { demolition wastes. }\end{array}$ & + & 6 \\
\hline $\begin{array}{l}\text { Boneyard, Bumyatd, and } \\
\text { Hazardous Chemical Storage } \\
\text { Area }\end{array}$ & CERCLA & $\begin{array}{l}\text { Magnesium chips, construction debris, } \\
\text { pesticide containers, metal shavings, } \\
\text { solvents, oils, laboratory chemicals, } \\
\text { acids, bascs, organics, water-reactive } \\
\text { compounds, and shock sensitive } \\
\text { compounds. }\end{array}$ & & - \\
\hline $\begin{array}{l}\text { Burial Grounds A (North and } \\
\text { South) }\end{array}$ & $\begin{array}{l}\text { RCRA } \\
\text { CERCLA }\end{array}$ & Waste oils, coolants, and spent solvests. & 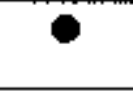 & . \\
\hline Burial Grounds C (West) & $\begin{array}{l}\text { RCRA } \\
\text { CERCLA }\end{array}$ & Waste oils, coolants, and spent solvents. & 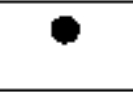 & . \\
\hline $\begin{array}{l}\text { Burial Grounds B, D, E, } \\
\text { and J }\end{array}$ & CERCLA & $\begin{array}{l}\text { Solid wastes including salts, metals } \\
\text { (beryllium and uranium) and metal } \\
\text { oxides, metal saw fines, and asbestos. }\end{array}$ & 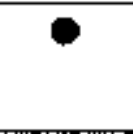 & \\
\hline $\begin{array}{l}\text { Enviroumental Management } \\
\text { Waste Management Facility }\end{array}$ & CERCLA & $\begin{array}{l}\text { Wastes generated from CERCLA } \\
\text { remediation actions. }\end{array}$ & $\cdot$ & 8 \\
\hline Oil Landfarm & $\begin{array}{l}\text { RCRA/ } \\
\text { CERCLA }\end{array}$ & $\begin{array}{l}\text { Waste oils and coolants containing } \\
\text { beryllimm connounds, depleted uranium, } \\
\text { polycklorinated biphenyls, and spent } \\
\text { Bolvents. }\end{array}$ & 6 & . \\
\hline Oil Retention Pond No. 1 & CERCLA & Oil seepage from Burial Ground A South. & ? & . \\
\hline Oil Retention Pond No. 2 & CERCLA & Oil seepage from Burial Ground A North. & - & 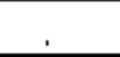 \\
\hline Receptar Media & CERCLA & $\begin{array}{l}\text { Contaminated groundwater, surface } \\
\text { water, Bear Creek stream sediments, and } \\
\text { Bear Creek flood plain soils. }\end{array}$ & & \\
\hline Rust Spoil Area & CERCLA & Nenradioactive construction debris. & 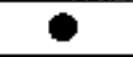 & . \\
\hline Sanitary Landfill I & CERCLA & Nothazärdous solid wastes. & 9 & . \\
\hline Spoil Area I & CERCLA & Nonrađioactive construction debris. & 8 & . \\
\hline SY-200 Yard & CERCLA & $\begin{array}{l}\text { Teuporary storage of oquipment, } \\
\text { machinery, and miscellaneous items. }\end{array}$ & 0 & . \\
\hline S-3 Site & $\begin{array}{c}\text { RCRA/ } \\
\text { CERCLA }\end{array}$ & $\begin{array}{l}\text { Liquid, radioactive, nitric acid wastes and } \\
\text { denitrification products. }\end{array}$ & 0 & . \\
\hline Walk-In Pits & $\begin{array}{l}\text { RCRA } \\
\text { CERCLA }\end{array}$ & $\begin{array}{l}\text { Chemical wastes, shock-sensitive } \\
\text { reagents, and uranium metal saw fines. }\end{array}$ & 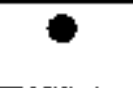 & . \\
\hline
\end{tabular}

Notes:

1 From: U.S. Department of Energy 1995. Oak Ridge Reservation Site Management Plan for the Environmental Restoration Progrim. U.S. Department of Energy Oak Ridge Field Office, DOE/OR-1001/R4.

CERCLA = Comprehensive Environmental Responsc, Compensation, and Liability Act of 1980

RCRA - Resource Conservation and Recovery Act of 1976

$\mathrm{NR}=$ Not regulated under RCRA or CERCLA 
Table 5. Sources of groundwater contaminant signatures in the tpper East Fork Poplar Creek Hydrogeologic Regime

\begin{tabular}{|c|c|c|c|c|}
\hline \multirow{2}{*}{$\begin{array}{l}\text { Conflrmed and Suspected } \\
\text { Sources of Contamination }\end{array}$} & \multicolumn{4}{|c|}{ Groundwater Contaminant Signature } \\
\hline & lnorganics & Organics & Metals & Radlonuclides \\
\hline \multicolumn{5}{|l|}{ Western Y-12 Area } \\
\hline Eastern S-3 Site Plunge & ? & P & - & - \\
\hline Salvage Yaja & & - & 5 & - \\
\hline \multicolumn{5}{|l|}{ Rus1 Garage Area } \\
\hline Waste Coolant Processing Are日 & & $\bullet$ & - & - \\
\hline \multicolumn{5}{|l|}{ Building 9204-4 } \\
\hline \multicolumn{5}{|l|}{ Fire Training Facility } \\
\hline \multicolumn{5}{|l|}{ Interim Drum Xard Vicinity } \\
\hline S-2 Sitd & 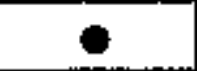 & 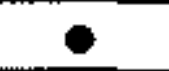 & 0 & 0 \\
\hline \multicolumn{5}{|l|}{ Central Y-12 Ares } \\
\hline \multicolumn{5}{|l|}{ Buildings $9201-4$ and $9201-5$} \\
\hline \multicolumn{5}{|l|}{ Building 9731 Vicinity } \\
\hline \multicolumn{5}{|l|}{ Building 9212 Vicinity } \\
\hline \multicolumn{5}{|l|}{ Tank 0134-U } \\
\hline \multicolumn{5}{|l|}{ Building 81-10 } \\
\hline \multicolumn{5}{|l|}{ Buildielgs 9201-1 and 9201-2 } \\
\hline \multicolumn{5}{|l|}{ Tank 2331-L } \\
\hline \multicolumn{5}{|l|}{ Eastern Y-12 Area } \\
\hline \multicolumn{5}{|l|}{ East End Garage (Buitding 9754-2) } \\
\hline Uranium Oxide Vauld & & & - & - \\
\hline \multicolumn{5}{|l|}{ Welks GW-605 and GW-606 Vicinity } \\
\hline Former Oil Stimmer Bagin & & & ? & - \\
\hline \multicolumn{5}{|l|}{ Easi End VOC Plume } \\
\hline Building $9720-6$ Vicinity & & 0 & & \\
\hline
\end{tabular}

Note:

1 Modified fron DOE (1998), Appendix D, Section D.5

B-10 
Table 6. Waste management sites and RCRA-regulated units in the Chestnut Ridge Hydrogeologic Regime

\begin{tabular}{|c|c|c|c|c|}
\hline \multirow{2}{*}{$\begin{array}{l}\text { Waste Management Siter } \\
\text { Regulated Unit }\end{array}$} & \multirow{2}{*}{$\begin{array}{c}\text { Regulatory } \\
\text { Classification }\end{array}$} & \multirow{2}{*}{ General Waste Inventory } & \multicolumn{2}{|c|}{ Status } \\
\hline & & & Active & Closed \\
\hline $\begin{array}{l}\text { Chestaut Ridge } \\
\text { Sediment Disposal Basin }\end{array}$ & $\begin{array}{c}\mathrm{RCRN} / \\
\text { CERCLA }\end{array}$ & $\begin{array}{l}\text { Approximately } 11,100 \text { yd of sediments and } \\
\text { soils from X-12 that contain heavy metnls; } \\
\text { approxinately } 100,000 \text { galions of methanol- } \\
\text { brine waste (70/30\% water/methyl alcohol); } \\
\text { and } 55-110 \text { gallons of toluene. }\end{array}$ & $\cdot$ & - \\
\hline $\begin{array}{l}\text { East Chestmut Ridge } \\
\text { Waste Pile }\end{array}$ & $\begin{array}{c}\text { RCRA/ } \\
\text { CERCLA } \\
\end{array}$ & $\begin{array}{l}\text { Approximately } 3800 \mathrm{yd}^{3} \text { of contaminated soil } \\
\text { from Y-12. }\end{array}$ & , & 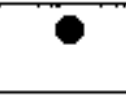 \\
\hline Ken Hollow Quany & $\begin{array}{c}\text { RCRA/ } \\
\text { CERCLA }\end{array}$ & $\begin{array}{l}\text { Appoximately } 50 \text { tons of water-reactive } \\
\text { materials (alkali metals, metal bydrides); } \\
\text { unstable otganic materials (pictic acid, ethers, } \\
\text { peroxides, and hydrazotc); reactive metals } \\
\text { (phosphorous and magnesium); potentially } \\
\text { explosive materials (e.g., gas cylinders); } \\
\text { ammonia; and inorganic acids. } \\
\end{array}$ & v & 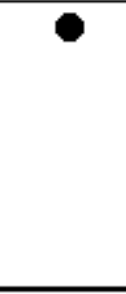 \\
\hline $\begin{array}{l}\text { Chestnut Ridge Security } \\
\text { Pits }\end{array}$ & $\begin{array}{l}\text { RCRA/ } \\
\text { CERCLA }\end{array}$ & $\begin{array}{l}\text { Metals (lead); reactive materials (lithium } \\
\text { bydride, lithium deuteride, zirconium); } \\
\text { corrosive materials (acids); ignitable materials } \\
\text { (alcobols); and chlorinated solvents. }\end{array}$ & . & 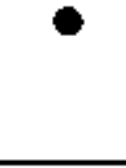 \\
\hline $\begin{array}{l}\text { Filled Coal Ash Pond } \\
\text { (formetly the Ash } \\
\text { Disposal Basin) }\end{array}$ & CERCLA & Coal fly-ash slurry from the Y-12 Steam Plant. & . & 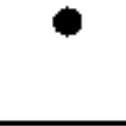 \\
\hline $\begin{array}{l}\text { United Nuclear } \\
\text { Corporation Site }\end{array}$ & CERCLA & $\begin{array}{l}\text { Approximately 11,000 drums (55-gallon) of } \\
\text { shidge fixed in cement, } 18,000 \text { dnums of } \\
\text { contaminated boil, and } 288 \text { boxes of } \\
\text { contaminated process and demolition material. }\end{array}$ & $\cdot$ & 7 \\
\hline Rogers Quarry & CERCLA & $\begin{array}{l}\text { Coal fly-ash silury that bypassod the Filled } \\
\text { Coal Ash Pond via spillway into McCoy } \\
\text { Branch. }\end{array}$ & . & 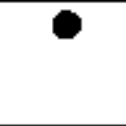 \\
\hline $\begin{array}{l}\text { Chestmut Ridge Borrow } \\
\text { Area Waste Pile }\end{array}$ & CERCLA & $\begin{array}{l}\text { Soils removed from the Oak Ridge Civic } \\
\text { Center properties and the Oak Ridge Sewer } \\
\text { Line Beltway contaminated with mercury and } \\
\text { other metals, and possibly some organic } \\
\text { conpounds that originated from Y-12. All soil } \\
\text { was removed from the site in CY } 2000 \text {. }\end{array}$ &. & 6 \\
\hline Industrial Landfill II & SWDF & $\begin{array}{l}\text { Combustible and decomposable solid waste } \\
\text { and construction spoil material including scrap } \\
\text { metal, glass, paper products, plastics, wood, } \\
\text { organic garbage, textile products, asphalt } \\
\text { joofing materials, and special wastes such as } \\
\text { asbestos and beryllium oxide. }\end{array}$ & . & 0 \\
\hline Industrial Landfill IV & SWDF & $\begin{array}{l}\text { Approximately } 12,000 \mathrm{ft} \text { per year of non- } \\
\text { hazatdous, tomradioactive industrial wastes } \\
\text { including cardboard, plastics, nbber, scrap } \\
\text { metal, wood, paper, and special ryaste. }\end{array}$ & 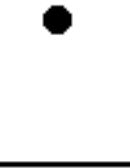 & , \\
\hline
\end{tabular}


Table 6 (contioued)

\begin{tabular}{|l|c|l|c|c|}
\hline $\begin{array}{l}\text { Waste Management Sitef } \\
\text { Regulated Unit }\end{array}$ & $\begin{array}{c}\text { Regulatory } \\
\text { Classification' }\end{array}$ & \multicolumn{1}{|c|}{ General Waste Inventory } & \multicolumn{2}{|c|}{ Status } \\
\cline { 3 - 5 } & SWDF & Combustible/decomposable solid wastes. & Closed \\
\hline Industrial Landfill V & SWDF & $\begin{array}{l}\text { Construction spoil: concrete, wood, melal, } \\
\text { plastic, roofing materials, and soil. }\end{array}$ & - & \\
\hline $\begin{array}{l}\text { Construction'Demolition } \\
\text { Landfill VI }\end{array}$ & SWDF & $\begin{array}{l}\text { Construction spoil: concrete, wood, metal, } \\
\text { plastic, roofing materials, and soil. }\end{array}$ & - &. \\
\hline $\begin{array}{l}\text { ConstructionDDemolition } \\
\text { Landfil VII }\end{array}$ & &
\end{tabular}

Notes:

1. CERCLA - Comprehensive Environmental Response, Compensation, and Liability Act of 1980

RCRA = Resource Conservation and Recovery Act of 1976

SWDF - Solid Waste Disposal Facility (nonkazardous waste) 
Table 7. Well construction details

\begin{tabular}{|c|c|c|c|c|c|c|}
\hline $\begin{array}{r}\text { Well Number } \\
\text { Permit (TNHW-) } \\
\text { Hydrogeologic Regime } \\
\text { Monitoring Program } \\
\text { Monitoring Purpose } \\
\text { TSD Unitt } \\
\text { TSD }\end{array}$ & $\begin{array}{c}\text { GW-008 } \\
116 \\
\text { BC } \\
\text { C. Action } \\
\text { POC } \\
\text { OLF }\end{array}$ & $\begin{array}{l}\text { GW-046 } \\
116 \\
\text { BC } \\
\text { C. Action } \\
\text { POC } \\
\text { BG }\end{array}$ & $\begin{array}{l}\text { GW-108 } \\
113 \\
\text { EF } \\
\text { C. Action } \\
\text { POC } \\
\text { Si East }\end{array}$ & $\begin{array}{l}\text { GW-143 } \\
128 \\
\text { CR } \\
\text { Detection } \\
\text { POC } \\
\text { KHQ }\end{array}$ & $\begin{array}{l}\text { GW-144 } \\
128 \\
\text { CR } \\
\text { Detection } \\
\text { POC } \\
\text { KHQ }\end{array}$ & $\begin{array}{l}\text { GW-145 } \\
128 \\
\text { CR } \\
\text { Detection } \\
\text { POC } \\
\text { KHQ }\end{array}$ \\
\hline $\begin{array}{r}\text { General Information } \\
\text { Date Installed } \\
\text { Total Depth Drilled } \\
\text { East Coordinate } \\
\text { North Coordinate } \\
\text { Measuring Point Elevation } \\
\text { Ground Surface Elevation } \\
\text { Hydrostratigraphic Unit } \\
\text { Geologic Formation } \\
\text { Aquifer Zoue } \\
\text { Weathered Rock-Depth } \\
\text { Fresh Rock-Depth }\end{array}$ & $\begin{array}{r}09 / 21 / 83 \\
25.5 \\
47,596 \\
29,783 \\
965.39 \\
962.11 \\
\text { Aquitard } \\
\text { Cn } \\
w T \\
0.6\end{array}$ & $\begin{array}{r}10 / 27 / 83 \\
20.5 \\
43,284 \\
29,562 \\
921.17 \\
918.13 \\
\text { Aquiard } \\
\text { Cn } \\
\text { WT } \\
7.7\end{array}$ & $\begin{array}{r}09 / 26 / 84 \\
58.6 \\
53,207 \\
30,070 \\
999.00 \\
995.80 \\
\text { Aquitard } \\
\text { Cn } \\
\text { BDR } \\
4.0\end{array}$ & $\begin{array}{r}10 / 24 / 85 \\
253.0 \\
63,522 \\
24,257 \\
913.98 \\
911.04 \\
\text { Aquiftr } \\
\text { OCk } \\
\text { BDR } \\
18.0 \\
\end{array}$ & $\begin{array}{r}10 / 24 / 85 \\
195.0 \\
63,502 \\
24,255 \\
913.54 \\
910.48 \\
\text { Aquifer } \\
\text { OckJoch } \\
\text { BDR } \\
40,0 \\
\end{array}$ & $\begin{array}{r}10 / 14 / 85 \\
110.0 \\
63,266 \\
24,441 \\
840.24 \\
837.29 \\
\text { Aquifer } \\
\text { OCk } \\
\text { BDR } \\
12.0 \\
\end{array}$ \\
\hline $\begin{array}{r}\text { Surface Casing } \\
\text { Casing Depth } \\
\text { Oulside Diameter } \\
\text { Casing Material }\end{array}$ & & & $\begin{array}{r}20.7 \\
10.63 \\
P V C 40 \\
\end{array}$ & $\begin{array}{r}20.9 \\
10.63 \\
P V C 40 \\
\end{array}$ & $\begin{array}{r}40.0 \\
12.5 \\
\mathrm{PVC} 40 \\
\end{array}$ & $\begin{array}{r}12.0 \\
12.5 \\
\text { PVC40 } \\
\end{array}$ \\
\hline $\begin{array}{r}\text { Well Casing } \\
{ }^{6} \\
\text { Borehole Depth } \\
\text { Borehole Diameter } \\
\text { Casing Depth } \\
\text { Outside Diarneter } \\
\text { Casing Material }\end{array}$ & $\begin{array}{r}25.5 \\
4.5 \\
15.7 \\
2.37 \\
S 5304\end{array}$ & $\begin{array}{r}20.5 \\
6 \\
8.1 \\
2.37 \\
\mathrm{~s} 5304\end{array}$ & $\begin{array}{r}58.6 \\
9 \\
46.7 \\
4.5 \\
\text { PVC } 40\end{array}$ & $\begin{array}{r}205.0 \\
10 \\
205.0 \\
6.62 \\
\text { SF25 }\end{array}$ & $\begin{array}{r}195.0 \\
11 \\
150.0 \\
4.5 \\
\text { PVC40 }\end{array}$ & $\begin{array}{r}110.0 \\
11 \\
88.5 \\
4.5 \\
\text { PVC40 }\end{array}$ \\
\hline 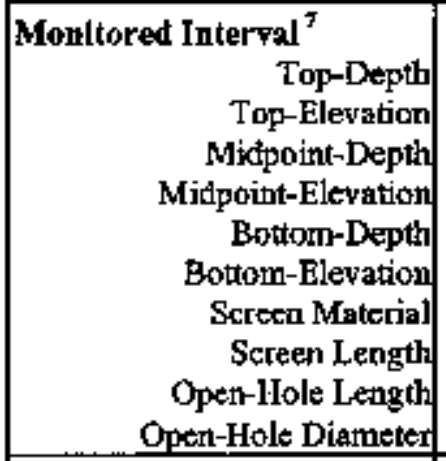 & $\begin{array}{r}13.0 \\
949.11 \\
19.3 \\
942.86 \\
25.5 \\
936.61 \\
\mathrm{SS} / \mathrm{sw} / .01 \\
5\end{array}$ & $\begin{array}{r}5.0 \\
913.13 \\
12.7 \\
905.48 \\
20.3 \\
897.83 \\
\text { SS/sw/01 } \\
10\end{array}$ & $\begin{array}{r}41.0 \\
954.80 \\
49.8 \\
946.00 \\
58.6 \\
937.20 \\
\text { PVCfs } / 01 \\
9\end{array}$ & $\begin{array}{r}205.0 \\
706.04 \\
229.0 \\
682.04 \\
253.0 \\
658.04\end{array}$ & $\begin{array}{r}148.0 \\
762.48 \\
171.5 \\
738.98 \\
195.0 \\
715.48 \\
\mathrm{PVC} / \mathrm{sw} / .01 \\
40\end{array}$ & $\begin{array}{r}86.0 \\
751.29 \\
98.0 \\
739.29 \\
110.0 \\
727.29 \\
\text { PVC/sw/.01 } \\
20\end{array}$ \\
\hline $\begin{array}{r}\text { Jedicated Pump Intake } \\
\text { Depth } \\
\text { Elevation }\end{array}$ & $\begin{array}{r}17.7 \\
944.39\end{array}$ & $\begin{array}{r}12.0 \\
906.17\end{array}$ & $\begin{array}{r}49.8 \\
946.00\end{array}$ & $\begin{array}{r}226.1 \\
684.98\end{array}$ & $\begin{array}{r}170.9 \\
739.54\end{array}$ & $\begin{array}{r}100.0 \\
737.24\end{array}$ \\
\hline
\end{tabular}


Table 7 (continued)

\begin{tabular}{|c|c|c|c|c|c|c|}
\hline $\begin{array}{r}\text { Well Number } \\
\text { Permit (TNHW-) } \\
\text { Hydrogeologic Regime } \\
\text { Monitorlng Program } \\
\text { Monitoring Purpose } \\
\text { TSD Unit } \\
\text { TS }\end{array}$ & \begin{tabular}{|c|} 
GW-156 \\
128 \\
CR \\
Detection \\
POC \\
CRSDB \\
\end{tabular} & $\begin{array}{c}\text { GW-159 } \\
\text { 128 } \\
\text { CR } \\
\text { Detection } \\
\text { UPG } \\
\text { CRSDB } \\
\end{array}$ & $\begin{array}{l}\text { GW-160 } \\
128 \\
\text { CR } \\
\text { Detection } \\
\text { POC } \\
\text { ECRWP }\end{array}$ & $\begin{array}{c}\text { GW-177 } \\
128 \\
\text { CR } \\
\text { C. Action } \\
\text { POC } \\
\text { CRSP }\end{array}$ & $\begin{array}{c}\text { GW-193 } \\
113 \\
\text { EF } \\
\text { C. Action } \\
\text { PLUML } \\
\text { S3 East }\end{array}$ & $\begin{array}{c}\text { GW-231 } \\
128 \\
\text { CR } \\
\text { Detection } \\
\text { UPG } \\
\text { KHQ }\end{array}$ \\
\hline $\begin{array}{r}\text { eneral Information } \\
\text { Date Installed } \\
\text { Total Depth Drilled } \\
\text { East Coordinate } \\
\text { North Coordinate } \\
\text { Mcasuting Point Elevation } \\
\text { Ground Surface Elevation } \\
\text { Hydtostratigraphic Unit } \\
\text { Geologic Fornation } \\
\text { Aquifer Zone } \\
\text { Weathered Rock-Depth } \\
\text { Fresh Rock-Depth }\end{array}$ & $\begin{array}{r}10 / 18 / 85 \\
157.6 \\
64,020 \\
27,626 \\
1,049.28 \\
1046.94 \\
\text { Aquifer } \\
\text { OCk } \\
\text { BDR } \\
84.0 \\
93.0 \\
\end{array}$ & $\begin{array}{r}10 / 18 / 85 \\
157.0 \\
63,496 \\
27,764 \\
1,051.38 \\
1048.79 \\
\text { Aquifer } \\
\text { OCk } \\
\text { BDR } \\
100.0 \\
\end{array}$ & $\begin{array}{r}07 / 18 / 87 \\
235.0 \\
62,165 \\
27.803 \\
1,093.09 \\
1090.66 \\
\text { Aquifer } \\
\text { OCk } \\
\text { WT } \\
60.0\end{array}$ & $\begin{array}{r}10 / 24 / 85 \\
145.0 \\
57,497 \\
28.483 \\
1,158.20 \\
1155.52 \\
\text { Aquifer } \\
\text { OCk } \\
\text { BDR } \\
62.0 \\
98.0 \\
\end{array}$ & $\begin{array}{r}08 j 04 / 89 \\
18.5 \\
59,536 \\
29,344 \\
934.17 \\
931.11 \\
\text { Aquifer } \\
\text { Cmn } \\
\text { WT } \\
2.5\end{array}$ & $\begin{array}{r}10 / 02 / 85 \\
35.0 \\
63,410 \\
24,725 \\
849.67 \\
846.90 \\
\text { Aquifer } \\
\text { OCk } \\
\text { BDR } \\
10.5\end{array}$ \\
\hline $\begin{array}{r}\text { Irface Casing }{ }^{5} \\
\text { Casing Depth } \\
\text { Outside Diameter } \\
\text { Casing Material } \\
\end{array}$ & $\begin{array}{r}94.0 \\
50.75 \\
\text { SF25 } \\
\end{array}$ & $\begin{array}{l}123.0 \\
10.75 \\
\text { SF25 } \\
\end{array}$ & $\begin{array}{r}112.5 \\
12.5 \\
\text { SF2.5 }\end{array}$ & $\begin{array}{r}82.0 \\
10.75 \\
\mathrm{SF} 25 \\
\end{array}$ & $\begin{array}{r}5.0 \\
9.63 \\
\text { STL } \\
\end{array}$ & $\begin{array}{r}11.0 \\
10.63 \\
\mathrm{PVC40} \\
\end{array}$ \\
\hline $\begin{array}{r}\text { Well Casing } \\
\text { Borehole Depth } \\
\text { Borehole Diameter } \\
\text { Casing Dept } \\
\text { Outside Diameter } \\
\text { Casing Material }\end{array}$ & $\begin{array}{r}157.0 \\
8.5 \\
147.0 \\
4.5 \\
\text { PVC40 }\end{array}$ & $\begin{array}{r}157.0 \\
8.5 \\
147.0 \\
4.5 \\
\text { PVC40 }\end{array}$ & $\begin{array}{r}205.0 \\
11 \\
205.0 \\
6.62 \\
\text { ST } 25 \\
\end{array}$ & $\begin{array}{r}145.0 \\
8 \\
133.0 \\
4.5 \\
\text { PVC } 40\end{array}$ & $\begin{array}{r}18.5 \\
8 \\
8.2 \\
4.5 \\
S 5304\end{array}$ & $\begin{array}{r}35.0 \\
11 \\
24.5 \\
4.5 \\
\text { PVC40 }\end{array}$ \\
\hline $\begin{array}{r}\text { anitored Interval }^{\top} \\
\text { Top-Depth } \\
\text { Top-Elevation } \\
\text { Midpouzt-Depth } \\
\text { Midpoint-Elevation } \\
\text { Bottom-Depth } \\
\text { Bottor-Elevation } \\
\text { Screen Matcrial } \\
\text { Screen Length } \\
\text { Opcn-Hole Length } \\
\text { Open-Hole Diametcr }\end{array}$ & $\begin{array}{r}145.0 \\
901.94 \\
151.3 \\
895.64 \\
157.6 \\
889.34 \\
\text { PVC/sw/.01 } \\
10\end{array}$ & $\begin{array}{r}145.0 \\
903.79 \\
151.0 \\
897.79 \\
157.0 \\
891.79 \\
\text { PVC/sw/.01 } \\
10\end{array}$ & $\begin{array}{r}205.0 \\
885.66 \\
220.0 \\
870.66 \\
235.0 \\
855.66 \\
. \\
30 \\
6\end{array}$ & $\begin{array}{r}130.0 \\
1,025.52 \\
137.5 \\
1,018.02 \\
145.0 \\
1,010.52 \\
\text { PYC/s1/.01 } \\
10\end{array}$ & $\begin{array}{r}5.5 \\
925.61 \\
12.0 \\
919.14 \\
18.5 \\
912.66 \\
\text { SS/sw/.01 } \\
10.3\end{array}$ & $\begin{array}{r}22.8 \\
824.11) \\
28.9 \\
818.00 \\
35.0 \\
811.90 \\
\text { PVC/sw } / .01 \\
10\end{array}$ \\
\hline $\begin{array}{r}\text { Dedicated Pamp Intake }^{2} \\
\text { Deptb } \\
\text { Elevation }\end{array}$ & $\begin{array}{r}150.7 \\
896.28\end{array}$ & $\begin{array}{r}148.4 \\
900.38\end{array}$ & & & $\begin{array}{r}13.9 \\
917.17\end{array}$ & $\begin{array}{r}28.7 \\
818.17 \\
\end{array}$ \\
\hline
\end{tabular}


Table 7 (continned)

\begin{tabular}{|c|c|c|c|c|c|c|}
\hline $\begin{array}{r}\text { Well Number } \\
\text { Permit (MNHW-) } \\
\text { Hydrogeologle Reginie } \\
\text { Moaitoring Program, } \\
\text { Monltoring Purpose } \\
\text { TSD Lnoit } \\
\text { 3. }\end{array}$ & $\begin{array}{c}\text { GW-276 } \\
116 \\
\text { BC } \\
\text { C. Action } \\
\text { POC } \\
\text { S3 } \\
\end{array}$ & $\begin{array}{c}\text { GW-292 } \\
128 \\
\text { CR } \\
\text { Detection } \\
\text { POC } \\
\text { ECRWP } \\
\end{array}$ & $\begin{array}{c}\text { GW-293 } \\
128 \\
\text { CR } \\
\text { Detection } \\
\text { POC } \\
\text { ECRWP }\end{array}$ & $\begin{array}{c}\text { GW-294 } \\
128 \\
\text { CR } \\
\text { Detection } \\
\text { UPG } \\
\text { ECRWP }\end{array}$ & $\begin{array}{l}\text { GW-296 } \\
128 \\
\text { CR } \\
\text { Detection } \\
\text { POC } \\
\text { ECRWP }\end{array}$ & $\begin{array}{c}\text { GW-298 } \\
128 \\
\text { CR } \\
\text { Detection } \\
\text { POC } \\
\text { ECRWP }\end{array}$ \\
\hline $\begin{array}{r}\text { General Information } \\
\text { Date Installed } \\
\text { Total Depth Drilled } \\
\text { East Cootdinate } \\
\text { North Coordinate } \\
\text { Measuring Point Elevation } \\
\text { Ground Surface Elevation } \\
\text { Hydrostratigraphic Unit } \\
\text { Geologic Formation } \\
\text { Aquifer Zone } \\
\text { Weathered Rock-Depth } \\
\text { Ftesh Rock-Depth }\end{array}$ & $\begin{array}{r}07 / 15 / 86 \\
18.5 \\
52,557 \\
29,926 \\
1,001.57 \\
998.70 \\
\text { Aquitard } \\
\mathrm{Cn} \\
\mathrm{WT} \\
18.5\end{array}$ & $\begin{array}{r}05 / 22 / 87 \\
186.0 \\
62,146 \\
28,141 \\
1,073,00 \\
1070.11 \\
\text { Aquifer } \\
\text { OCk } \\
\text { BDR } \\
32.0 \\
59.5 \\
\end{array}$ & $\begin{array}{r}06 / 11 / 87 \\
214.0 \\
62,321 \\
28,112 \\
1,063.90 \\
1061.70 \\
\text { Aquifer } \\
\text { OCk } \\
\text { BDR } \\
57.0 \\
110.0 \\
\end{array}$ & $\begin{array}{r}05 / 01 / 87 \\
128.0 \\
62,483 \\
27,958 \\
1,083.60 \\
1083.67 \\
\text { Aquifer } \\
\text { OCk } \\
\text { BDR } \\
62.0 \\
87.0 \\
\end{array}$ & $\begin{array}{r}05 / 11 / 87 \\
147.0 \\
62,023 \\
27,994 \\
1,090.99 \\
1088.29 \\
\text { Aquifer } \\
\text { OCk } \\
\text { BDR } \\
67.0 \\
81.5 \\
\end{array}$ & $\begin{array}{r}07 / 27 / 87 \\
190.0 \\
62,445 \\
27,495 \\
1,049.01 \\
1046.40 \\
\text { Aquifer } \\
\text { OCk } \\
\text { BDR } \\
65.0 \\
80.0\end{array}$ \\
\hline $\begin{array}{r}\text { Surface Casing } \\
\text { Casing Depth } \\
\text { Outside Diameter } \\
\text { Casing Materia] } \\
\end{array}$ & & $\begin{array}{r}51.0 \\
10.75 \\
S F 25 \\
\end{array}$ & $\begin{array}{r}57.8 \\
10.75 \\
5 F 25 \\
\end{array}$ & $\begin{array}{r}74.5 \\
10.75 \\
\text { SF25 } \\
\end{array}$ & $\begin{array}{r}86.5 \\
10.75 \\
\text { SF25 } \\
\end{array}$ & $\begin{array}{r}83.3 \\
10.75 \\
\text { SF25 } \\
\end{array}$ \\
\hline $\begin{array}{r}\text { Woll Casing }^{6} \\
\text { Borehole Depth } \\
\text { Borehole Diameter } \\
\text { Casing Depth } \\
\text { Outside Diameter } \\
\text { Casing Material } \\
\end{array}$ & $\begin{array}{r}18.5 \\
8 \\
13.0 \\
4.5 \\
S \$ 304 \\
\end{array}$ & $\begin{array}{r}186.0 \\
10 \\
174.1 \\
4.5 \\
S S 304\end{array}$ & $\begin{array}{r}197.0 \\
10 \\
197.0 \\
6.62 \\
S F 25 \\
\end{array}$ & $\begin{array}{r}128.0 \\
10 \\
117.6 \\
4.5 \\
58304 \\
\end{array}$ & $\begin{array}{r}147.0 \\
10 \\
136.3 \\
4.5 \\
S S 304 \\
\end{array}$ & $\begin{array}{r}190.0 \\
10 \\
176.0 \\
4.5 \\
S S 304 \\
\end{array}$ \\
\hline \begin{tabular}{|r|} 
Monitored Interval \\
Top-Depth \\
Top-Elevation \\
Midpoint-Depth \\
Midpoint-Elevation \\
Bottom-Depth \\
Bottom-Elevation \\
Screen Material \\
Screen Length \\
Open-Hole Length \\
Open-Hole Diameter
\end{tabular} & $\begin{array}{r}11.3 \\
987.40 \\
14.9 \\
983.80 \\
18.5 \\
980.20 \\
5 S / 5 w / 01 \\
5.3\end{array}$ & $\begin{array}{r}172.1 \\
898.01 \\
179.1 \\
891.06 \\
186.0 \\
884.11 \\
\text { SS/swi.01 } \\
10.7\end{array}$ & $\begin{array}{r}197.0 \\
864.70 \\
205.5 \\
856.20 \\
214.0 \\
847.70\end{array}$ & $\begin{array}{r}113.0 \\
970.67 \\
120.5 \\
963.17 \\
128.0 \\
955.67 \\
\text { SS/sw/.01 } \\
10.4\end{array}$ & $\begin{array}{r}134.4 \\
953.89 \\
140.7 \\
947.59 \\
147.0 \\
941.29 \\
\text { SS/sw/.01 } \\
10.5\end{array}$ & $\begin{array}{r}171.1 \\
875.30 \\
180.6 \\
865.85 \\
190.0 \\
856.40 \\
\text { Ss/sw/.01 } \\
10\end{array}$ \\
\hline $\begin{array}{r}\text { Dedicated Punp Intake } \\
\text { Depth } \\
\text { Elevation }\end{array}$ & $\begin{array}{r}14.1 \\
984.57\end{array}$ & & & & & \\
\hline
\end{tabular}


Table 7 (continued)

\begin{tabular}{|c|c|c|c|c|c|c|}
\hline $\begin{array}{r}\text { Well Number } \\
\text { Permit (TNHW-) } \\
\text { Hydrogeologic Regime } \\
\text { Monltoring Program } \\
\text { Monitoring Purpose } \\
\text { TSD Unitt }\end{array}$ & $\begin{array}{c}\text { GW-3DI } \\
128 \\
\text { CR } \\
\text { C. Action } \\
\text { PLLJME } \\
\text { CRSP } \\
\end{array}$ & $\begin{array}{c}\text { GW-521 } \\
128 \\
\text { CR } \\
\text { C. Action } \\
\text { UPG } \\
\text { CRSP }\end{array}$ & $\begin{array}{l}\text { GW-557 } \\
128 \\
\text { CR } \\
\text { C. Action } \\
\text { PLUME } \\
\text { CRSP }\end{array}$ & $\begin{array}{c}\text { GW-562 } \\
128 \\
\text { CR } \\
\text { C. Action } \\
\text { PLUME } \\
\text { CRSP } \\
\end{array}$ & $\begin{array}{l}\text { GW-605 } \\
113 \\
\text { EF } \\
\text { C. Action } \\
\text { PLUME } \\
\text { S3 East }\end{array}$ & $\begin{array}{c}\text { GW-606 } \\
113 \\
\text { EF } \\
\text { C. Action } \\
\text { PLUME } \\
\text { S3 East }\end{array}$ \\
\hline $\begin{array}{r}\text { eneral Information }{ }^{4} \\
\text { Date lastalled } \\
\text { Total Depth Drilled } \\
\text { East Coordinete } \\
\text { North Coordinate } \\
\text { Measuring Point Elevation } \\
\text { Ground Surface Elevation } \\
\text { Hydrostratigraphic Unit } \\
\text { Geologic Formation } \\
\text { Aquifer Zone } \\
\text { Weathered Rock-Depth } \\
\text { Fresh Rock-Depth }\end{array}$ & $\begin{array}{r}07 / 02 / 87 \\
182.0 \\
61,964 \\
27,662 \\
1,086.55 \\
1083.94 \\
\text { Aquifer } \\
\text { OCk } \\
\mathrm{BDR} \\
94.0 \\
136.0\end{array}$ & $\begin{array}{r}09 / 14 / 88 \\
136.0 \\
52,040 \\
28,541 \\
1,182.88 \\
1179.46 \\
\text { Aquifer } \\
\text { OCk } \\
\text { BDR } \\
54.0\end{array}$ & $\begin{array}{r}12 / 02 / 88 \\
139.0 \\
59,520 \\
26,450 \\
1,081.36 \\
1078.63 \\
\text { Aquifer } \\
\text { OCk } \\
\text { WT } \\
113.8 \\
134,0\end{array}$ & $\begin{array}{r}01 / 13 / 89 \\
133.0 \\
61,640 \\
26,276 \\
934,69 \\
931.86 \\
\text { Aquifir } \\
\text { OCk } \\
\text { WT } \\
\$ 2.0\end{array}$ & $\begin{array}{r}03 / 19 / 91 \\
40.5 \\
62,002 \\
28,707 \\
919.06 \\
916.97 \\
\text { Aquifer } \\
\text { Conn } \\
\text { BDR }\end{array}$ & $\begin{array}{r}03 / 20 / 91 \\
175.0 \\
61,951 \\
28,708 \\
919.59 \\
916.98 \\
\text { Aquifer } \\
\text { Cmin } \\
\text { BDR } \\
10.8 \\
\end{array}$ \\
\hline $\begin{array}{r}\text { urface Casiog }^{5} \\
\text { Casing Depth } \\
\text { Outside Diameter } \\
\text { Casing Material }\end{array}$ & $\begin{array}{l}105.0 \\
10.75 \\
\text { SF25 }\end{array}$ & $\begin{array}{r}60.5 \\
10.75 \\
\text { STL } \\
\end{array}$ & $\begin{array}{r}85.0 \\
10.75 \\
\text { STL } \\
\end{array}$ & & $\begin{array}{r}9.5 \\
11.75 \\
\text { SI55 } \\
\end{array}$ & $\begin{array}{r}64.7 \\
7 \\
\text { SJ55 } \\
\end{array}$ \\
\hline $\begin{array}{r}\text { Well Casing }^{6} \\
\text { Borehole Depth } \\
\text { Borehole Diameter } \\
\text { Casing Depth } \\
\text { Outside Diameter } \\
\text { Casing Material } \\
\end{array}$ & $\begin{array}{r}163.5 \\
10 \\
151.0 \\
4.5 \\
S S 304 \\
\end{array}$ & $\begin{array}{r}136.0 \\
9.5 \\
124.9 \\
4.5 \\
S 5304 \\
\end{array}$ & $\begin{array}{r}138.0 \\
9.5 \\
115.8 \\
4.5 \\
58304 \\
\end{array}$ & $\begin{array}{r}60.0 \\
9.5 \\
38.0 \\
4.5 \\
S \$ 304 \\
\end{array}$ & $\begin{array}{r}40.5 \\
10.6 \\
29.7 \\
4.25 \\
\text { S5304 } \\
\end{array}$ & $\begin{array}{r}175.0 \\
9.63 \\
161.0 \\
4.25 \\
S 8304 \\
\end{array}$ \\
\hline $\begin{array}{r}\text { Ionitored Interval } \\
\text { Top-Depth } \\
\text { Top-Elevation } \\
\text { Midpoint-Depth } \\
\text { Midpoint-Elevation } \\
\text { Bottort-Depth } \\
\text { Bottom-Elevation } \\
\text { Screen Materia] } \\
\text { Screes Length } \\
\text { Open-Hole Length } \\
\text { Open-Hole Diarnetes }\end{array}$ & $\begin{array}{r}148.5 \\
935.44 \\
156.0 \\
927.94 \\
163.5 \\
920.44 \\
\text { SS/8w/.01 } \\
10\end{array}$ & $\begin{array}{r}123.2 \\
1,056.26 \\
129.6 \\
1,049.86 \\
136.0 \\
1,043.46 \\
\mathrm{SS} / \mathrm{s} / .01 \\
10.3\end{array}$ & $\begin{array}{r}112.9 \\
965.73 \\
125.5 \\
953.18 \\
138.0 \\
940.63 \\
\text { SSiswi.01 } \\
20\end{array}$ & $\begin{array}{r}36.0 \\
895.86 \\
48.0 \\
883.86 \\
60.0 \\
871.86 \\
\text { SS/sw } / .01 \\
20\end{array}$ & $\begin{array}{r}28.2 \\
888.77 \\
34.1 \\
882.92 \\
39.9 \\
877.07 \\
\mathrm{SS} / \mathrm{sw} / .01 \\
10\end{array}$ & $\begin{array}{r}155.0 \\
761.98 \\
163.0 \\
753.98 \\
171.0 \\
745.98 \\
\text { SS/ppk } / 01 \\
10\end{array}$ \\
\hline $\begin{array}{r}\text { Dedicated Purng Intake } \\
\text { Depth }^{\mathrm{B}} \\
\text { Elevation }\end{array}$ & $\begin{array}{r}157.4 \\
926.55\end{array}$ & $\begin{array}{r}129.0 \\
1,050.48\end{array}$ & $\begin{array}{r}123.6 \\
955.06\end{array}$ & $\begin{array}{r}48.2 \\
883.69\end{array}$ & $\begin{array}{r}33.9 \\
883.06\end{array}$ & $\begin{array}{r}166.4 \\
750.59\end{array}$ \\
\hline
\end{tabular}


Table 7 (continued)

\begin{tabular}{|c|c|c|c|c|c|c|}
\hline $\begin{array}{r}\text { Well Namber } \\
\text { Permit (TNHW-y } \\
\text { Hydrogeologic Reglme } \\
\text { Monitorlng Program } \\
\text { Monitoring Purpose } \\
\text { TSD Unit } \\
\text { TS }\end{array}$ & $\begin{array}{l}\text { GW-712 } \\
116 \\
\text { BC } \\
\text { C. Action } \\
\text { PLUME } \\
\text { EXP }\end{array}$ & $\begin{array}{c}\text { GW-713 } \\
116 \\
\text { BC } \\
\text { C. Action } \\
\text { PLUME } \\
\text { EXP }\end{array}$ & $\begin{array}{c}\text { GW-714 } \\
116 \\
\text { BC } \\
\text { C. Action } \\
\text { PLUME } \\
\text { EXP }\end{array}$ & $\begin{array}{l}\text { GW-731 } \\
128 \\
\text { CR } \\
\text { Detection } \\
\text { POC } \\
\text { CRSDB }\end{array}$ & $\begin{array}{c}\text { GW-732 } \\
128 \\
\text { CR } \\
\text { Detection } \\
\text { POC } \\
\text { CRSDB }\end{array}$ & $\begin{array}{l}\text { GW-733 } \\
113 \\
\text { EF } \\
\text { C. Action } \\
\text { PLUME } \\
\text { S3 East }\end{array}$ \\
\hline $\begin{array}{r}\text { Teneral lnformationd } \\
\text { Date Installed } \\
\text { Total Depth Drilled } \\
\text { East Coordinate } \\
\text { North Coordinate } \\
\text { Measuring Point Elevation } \\
\text { Ground Sunface Elevation } \\
\text { Hydrostratigraphic Unit } \\
\text { Geologic Formation } \\
\text { Aquifer Zone } \\
\text { Weathered Rock-Depth } \\
\text { Fresh Rock-Depth }\end{array}$ & $\begin{array}{r}06 / 20 / 91 \\
457.5 \\
36,507 \\
28,233 \\
877.89 \\
873.61 \\
\text { Aquifer } \\
\text { OCk } \\
\text { BDR } \\
12.0 \\
66.0 \\
\end{array}$ & $\begin{array}{r}01 / 13 / 92 \\
315.2 \\
36,434 \\
28,236 \\
881.43 \\
877.83 \\
\text { Aquifer } \\
\text { Cnn } \\
\text { BDR } \\
26.8 \\
63.8 \\
\end{array}$ & $\begin{array}{r}01 / 24 / 92 \\
145,0 \\
36,435 \\
28,422 \\
875.88 \\
872.30 \\
\text { Aquifer } \\
\text { Cmu } \\
\text { BDR } \\
27.0 \\
35.0 \\
\end{array}$ & $\begin{array}{r}09 / 12 / 91 \\
180.4 \\
63,863 \\
27,464 \\
1,049.38 \\
1045.75 \\
\text { Aquifex } \\
\text { OCk } \\
\text { BDR } \\
95.4 \\
129.4 \\
\end{array}$ & $\begin{array}{r}09 / 11 / 91 \\
190.6 \\
64,268 \\
27,717 \\
1,064.29 \\
1060.65 \\
\text { Aquifer } \\
\text { OCk } \\
\text { BDR } \\
85.0 \\
96.0 \\
\end{array}$ & $\begin{array}{r}10 / 02 / 91 \\
256.5 \\
65,067 \\
28,447 \\
959.84 \\
955.69 \\
\text { Aquifer } \\
\text { Cmm } \\
\text { BDR } \\
42.5 \\
47.1\end{array}$ \\
\hline $\begin{array}{r}\text { Irface Casing }{ }^{s} \\
\text { Casing Depth } \\
\text { Outside Diarneter } \\
\text { Casing Material } \\
\end{array}$ & $\begin{array}{r}44.8 \\
11.75 \\
\text { SJ } 55 \\
\end{array}$ & $\begin{array}{r}80.2 \\
\text { SJ } 55 \\
\end{array}$ & $\begin{array}{r}40.5 \\
11.75 \\
5155 \\
\end{array}$ & $\begin{array}{r}122.0 \\
11.75 \\
\text { S155 } \\
\end{array}$ & $\begin{array}{r}100.7 \\
11.75 \\
\text { Sys5 } \\
\end{array}$ & $\begin{array}{r}51.8 \\
11.75 \\
\text { SJ55. } \\
\end{array}$ \\
\hline $\begin{array}{r}\text { Well Casing } \\
\text { Borehole Depth } \\
\text { Borehole Diameter } \\
\text { Casing Depth } \\
\text { Outside Diameter } \\
\text { Casing Material }\end{array}$ & $\begin{array}{r}441.5 \\
10.6 \\
440.2 \\
7 \\
\text { SF25 }\end{array}$ & $\begin{array}{r}305.0 \\
10.6 \\
303.7 \\
7 \\
\mathrm{SF} 25\end{array}$ & $\begin{array}{r}115.1 \\
10.6 \\
113.8 \\
7 \\
\mathrm{SF} 25\end{array}$ & $\begin{array}{r}175.4 \\
10.6 \\
165.2 \\
4.5 \\
S S 304\end{array}$ & $\begin{array}{r}189.5 \\
10.6 \\
179.3 \\
4.5 \\
8 S 304\end{array}$ & $\begin{array}{r}240.1 \\
10.6 \\
238.8 \\
7 \\
\text { SF25 }\end{array}$ \\
\hline $\begin{array}{r}\text { Monitored Interval } \\
\text { Top-Depth } \\
\text { Top-Elevation: } \\
\text { Midpoint-Depth } \\
\text { Midpoint-Elevation } \\
\text { Bottom-Depth } \\
\text { Botton-Elevation } \\
\text { Screen Material } \\
\text { Screcs Length } \\
\text { Open-Hole Length } \\
\text { Open-Hole Diameter } \\
\end{array}$ & $\begin{array}{r}441.5 \\
432.11 \\
449.5 \\
424.11 \\
457.5 \\
416.11 \\
\\
16 \\
6.25 \\
\end{array}$ & $\begin{array}{r}305.0 \\
572.83 \\
310.1 \\
567.73 \\
315.2 \\
562.63 \\
\\
10.2 \\
6.25 \\
\end{array}$ & $\begin{array}{r}115.1 \\
757.20 \\
130.1 \\
742.25 \\
145.0 \\
727.30 \\
\\
29.9 \\
6.25 \\
\end{array}$ & $\begin{array}{r}164.0 \\
881.75 \\
171.4 \\
874.40 \\
178.7 \\
867.05 \\
\text { SS/sw/.01 } \\
10\end{array}$ & $\begin{array}{r}178.3 \\
882.35 \\
184.2 \\
876.50 \\
190.0 \\
870.65 \\
\mathrm{SS} / \mathrm{sw} / .01 \\
10\end{array}$ & $\begin{array}{r}240.1 \\
715.59 \\
248.3 \\
707.39 \\
256.5 \\
699.19\end{array}$ \\
\hline $\begin{array}{r}\text { Iedicated Pump Intake }{ }^{\mathrm{B}} \\
\text { Depth } \\
\text { Elevation }\end{array}$ & $\begin{array}{r}446.2 \\
427.39\end{array}$ & $\begin{array}{r}307.4 \\
570.43\end{array}$ & $\begin{array}{r}138.4 \\
733.88\end{array}$ & $\begin{array}{r}169.9 \\
875.88\end{array}$ & $\begin{array}{r}184.4 \\
876.29\end{array}$ & $\begin{array}{r}248.9 \\
706.84\end{array}$ \\
\hline
\end{tabular}


Table 7 (contitued)

\begin{tabular}{|c|c|c|c|}
\hline $\begin{array}{r}\text { Well Number } \\
\text { Permilt (TNFW-) } \\
\text { Hydrogeologic Regime } \\
\text { Monitoring Program } \\
\text { Monitoring Purpose } \\
\text { TSD Unit } \\
\text { TS }\end{array}$ & $\begin{array}{c}\text { GW-799 } \\
128 \\
\text { CR } \\
\text { C. Action } \\
\text { PLUME } \\
\text { CRSP } \\
\end{array}$ & $\begin{array}{c}\text { GW-801 } \\
128 \\
\text { CR } \\
\text { C. Action } \\
\text { PLUME } \\
\text { CRSP } \\
\end{array}$ & $\begin{array}{l}\text { GW-831 } \\
128 \\
\text { CR } \\
\text { C. Action } \\
\text { PLUME } \\
\text { CRSP }\end{array}$ \\
\hline $\begin{array}{r}\text { eneral Information } \\
\text { Date Installed } \\
\text { Total Depth Drilled } \\
\text { East Coordinate } \\
\text { Notth Coordinate } \\
\text { Measuring Point Elevation } \\
\text { Ground Surface Elevation } \\
\text { Hydrostratigraphic Unit } \\
\text { Geologic Formation } \\
\text { Aquifer Zone } \\
\text { Weathered Rock-Depth } \\
\text { Fresh Rock-Depth }\end{array}$ & $\begin{array}{r}03 / 25 / 93 \\
92.0 \\
59,961 \\
26,746 \\
981.29 \\
978.10 \\
\text { Aquifer } \\
\text { OCk } \\
\text { BDR } \\
60.8 \\
62.8 \\
\end{array}$ & $\begin{array}{r}07 / 01 / 93 \\
188.9 \\
58,780 \\
26,808 \\
1,097.16 \\
1093.82 \\
\text { Aquifet } \\
\text { OCR } \\
\text { BDR } \\
112.5 \\
113.4 \\
\end{array}$ & $\begin{array}{r}07 / 30 / 96 \\
200.0 \\
56,593 \\
26,654 \\
1,091.29 \\
1088.04 \\
\text { Aquifet } \\
\text { DCk } \\
\text { IBDR } \\
134.8 \\
140.8 \\
\end{array}$ \\
\hline $\begin{array}{r}\text { Surlace Casing } \\
\text { Casing Depth } \\
\text { Outside Diamter } \\
\text { Casing Material }\end{array}$ & $\begin{array}{r}65.0 \\
10.75 \\
\text { SJ55 } \\
\end{array}$ & $\begin{array}{r}115.4 \\
10.75 \\
\text { SJ5.5 }\end{array}$ & $\begin{array}{r}138.3 \\
10.75 \\
\text { STL } \\
\end{array}$ \\
\hline $\begin{array}{r}\text { Well Cosing } \\
\text { Borehole Depth } \\
\text { Borehole Diameter } \\
\text { Casing Depth } \\
\text { Outside Diameter } \\
\text { Casing Material }\end{array}$ & $\begin{array}{r}92.0 \\
9.5 \\
81.0 \\
4.5 \\
85304\end{array}$ & $\begin{array}{r}188.9 \\
9.87 \\
178.1 \\
4.5 \\
5 S 304\end{array}$ & $\begin{array}{r}200.0 \\
9.87 \\
183.2 \\
4.5 \\
\text { SS }\end{array}$ \\
\hline $\begin{array}{r}\text { Monltored Interval }{ }^{7} \\
\text { Top-Depth } \\
\text { Top-Elevation } \\
\text { Midpoint-Depth } \\
\text { Midpoint-Elevation } \\
\text { Bottom-Depth } \\
\text { Bottom-Elevation } \\
\text { Screen Material } \\
\text { Screen Length } \\
\text { Open-Hole Length } \\
\text { Open-Hole Diameter }\end{array}$ & $\begin{array}{r}78.7 \\
899.40 \\
85.4 \\
892.75 \\
92.0 \\
886.10 \\
\mathrm{SS} / \mathrm{sw} / 0 \mathrm{1} \\
9.9\end{array}$ & $\begin{array}{r}175.8 \\
918.02 \\
182.4 \\
911.47 \\
188.9 \\
904.92 \\
\text { SS } / \mathrm{sw} / .01 \\
9.9\end{array}$ & $\begin{array}{r}182.0 \\
906.04 \\
190.8 \\
897.24 \\
199.6 \\
888.44 \\
\text { SS/sw/.01 } \\
10.4\end{array}$ \\
\hline $\begin{array}{r}\text { Dedicated Pump Intake } \\
\text { Depth } \\
\text { Elevation }\end{array}$ & $\begin{array}{r}84.8 \\
893.29\end{array}$ & $\begin{array}{r}177.7 \\
916.16\end{array}$ & $\begin{array}{r}188.8 \\
899.29\end{array}$ \\
\hline
\end{tabular}




\section{Table 7 (continued)}

Notes:

Data compiled from: $\quad$ BWXT (BWXT Y-12, L.L.C.) 2003. Updated Subsurface Data Base for Bear Creek Valley, Chestnut Ridge, and Parts of Bethel Valley on the U.S. Department of Energy Oak Ridge Reservation, YTS-881/R5, Oak Ridge, TN.

$\mathrm{BC}=$ Bear Creek Hydrogeplogic Regime

CR $\therefore$ Chestnut Ridge Hydrogeologic Regime

EF = Upper East Fork Poplar Crcek Hydrogeologic Regiune

2

PLUME = plume boundary

$P O C=$ point-of-compliance

UPG = upgradienthackgtound

BG = Bear Creek Burial Grounds WMA

CRSDB $=$ Chestnut Ridge Sediment Disposal Basin

CRSP = Chestmut Ridge Security Pits

ECRWP = East Chestrut Ridge Waste Pile

EXP I Exit Pathway for BG, OLF, and S3

KHQ = Kerr Hollow Quarry

OLF = Oil Landfano WMA

S3 = S-3 Site

S3 East = Eastern S-3 Site Plume

4

Cootdinates $=$ Y-12 grid system

Elevations = feet above near sea level

Depths = feet below ground surface

BDR = bectrock interval

WT = water table interval

Dch = Chickamauga CHoup

OCx = Knox Group

$\mathrm{Cm}$ - Maryville Limestone

$\mathrm{Co}=$ Nolichucky Shale

Cron = Maynandville Linestone

6

Depth = feet below ground suface

Diameters - outside dimensions, in inches (nominal)

SS'\#304 = stainless stecl, schedule 304

F25/J55 = Anerican Petroleum Institute Grade

PVC = polyvinyl chioride, schedule 40

Steel = carbon steel

7 Elevations = feet above mean sta level

Depths = feet below grownd sufacc; pump intake is depth from measuring point (MP)

Length $=$ feet

Top = depth to top of filier pack or open-hole

Bottom $=$ depth to bottom of filter pack or open-hole

PVC/sU.OI = polyvinyl chloride, 0.01 -inct slot size

PVC/sw/.01 a polyvinyl chloride, spiral wound, 0.01-inch slot size

SS/pp/OOl = stainless steel prepacked screen, spinal wound, 0.01-inch slot size

SStsw/.01 = stainless steel, spiral wound, 0.01-inch slot size

8 Depth = feet below the measuring point (approximate)

Elevation = feet above mean sca level 
Table 8. Field measurements and RCRA groundwater target componds for the S-3 Site, Oil Landfarm, and Bear Creek Burial Grounds/Walk-In Pits

\begin{tabular}{|c|c|c|c|c|c|c|}
\hline \multirow{2}{*}{ Messurement/Analyte } & \multicolumn{4}{|c|}{ Target Coustituents ${ }^{I}$} & \multirow{2}{*}{$\begin{array}{c}\text { Procedure/ } \\
\text { Analyteal Method }\end{array}$} & \multirow{2}{*}{$\mathbf{P Q L}^{3}$} \\
\hline & S-3 & OLF & $\mathrm{BG}$ & PB & & \\
\hline \multicolumn{7}{|l|}{ Field Mensarements } \\
\hline Depth to Water & $\dot{-}$ & + & s. & . & EDAM-SAMP-0100 & NA \\
\hline Water Temperature & . & . & . & . & EDAM-SAMP-1203 & NA \\
\hline $\mathrm{pH}$ & - &. &. & . & EDAM-SAMP-1204 & NA \\
\hline Conductivity & $\therefore$ & + & $\therefore$ & . & EDAM-SAMP-1208 & NA \\
\hline Dissolved Oxygen & + & . & $\therefore$ & . & EDAM-SAMP-1205 & NA \\
\hline Qxidation-Reduction Potential & - & $\therefore$ & . & . & EDAM-SAMP-1207 & NA \\
\hline Turbidity & + & - &. & سم & EDAM-SAMP-1211 & NA \\
\hline \multicolumn{7}{|l|}{ Inorganics (milligrams per liter) } \\
\hline Barium & $\circ$ & 으 & - & - & SW846-6010B & 0.005 \\
\hline Cadmium & 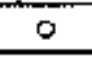 & 웅 & $\dot{.}$ & + & SW846-6010B & $0.00013^{*}$ \\
\hline Chroniurn & o & . & . & $\dot{.}$ & SW846-6010B & 0.005 \\
\hline Mereury & O & 0 & . & $\dot{-}$ & SW846-7470 & 0.0002 \\
\hline Nickel & o & . & . & . & SW846-6010B & 0.01 \\
\hline Nitrate (as N) & $\bullet$ & . & . & $\bullet$ & EPA-353.2 & 0.1 \\
\hline Uraniłam & - & o & 0 & $\circ$ & $\begin{array}{c}\text { ASTM-D5174-97 or } \\
\text { SW846-6020A }\end{array}$ & 0.004 \\
\hline \multicolumn{7}{|l|}{ Organics (micrograms per liter) } \\
\hline Acetone & 0 & . & . & . & SW846-8260 & 10 \\
\hline Benzene &. & . & $\bullet$ & 은 & $5 W 846-8 \overline{260}$ & $2.5^{*}$ \\
\hline Chloroform & 0 & . & . & . & SW846-8260 & 5 \\
\hline 1,1-Dichloroethane & . & . & $\bullet$ & $\therefore$ & SW846-8260 & 5 \\
\hline 1,1-Dichlorocthene & . & 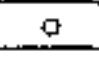 & $\circ$ & . & SW846-8260 & $3.5^{*}$ \\
\hline cis-1,2-Dichloroethene & $\circ$ & $\bullet$ & $\bullet$ & 0 & SW846-8260 & 5 \\
\hline Metbylene Chioride & o & . & . & 0 & SW846-8260 & $2.5^{*}$ \\
\hline Tetrachloroethene & $\bullet$ & $\bullet$ & $\bullet$ & 은 & SW846-8260 & $2.5^{*}$ \\
\hline 1,1,1-Trichloroethane & - & . & $\bullet$ & 0 & \$W846-8260 & 5 \\
\hline Trichloroethene & 웅 & $\bullet$ & سי & 웅 & SW846-8260 & $2.5^{*}$ \\
\hline Viny] Chioride & i & + & 0 & . & $S W 846-8260$ & $1^{*}$ \\
\hline \multicolumn{7}{|l|}{ Radioanglytes (picoCuries per liter) } \\
\hline Gross Alpha Activity & 0 & $\circ$ & 0 & P & EPA-900.0 & 5 \\
\hline Gross Beta Activity & 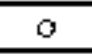 & 0 & 은 & 0 & EPA-900.0 & 5 \\
\hline Americiurn-241 & 0 & . & . & . & EPA-907,0 & 0.4 \\
\hline Neptunium-237 & o & . & . & . & EPA-907,0 & 0.4 \\
\hline Total Radium & 0 & $\therefore$ & . & . & EPA-903.0 & 0.5 \\
\hline Strontium-90 & o & . &. & . & EPA-905.0 & 4 \\
\hline Technetium-99 & $\bullet$ & $\therefore$ & 0 & 0 & LSC & 10 \\
\hline Uranium $-234,-235$, and -238 & o & . & 0 & 0 & EPA-908.0 & 1 \\
\hline
\end{tabular}




\section{Table 8 (continned)}

Notes:

1. Groundwater target list constituent specified in the RCRA post-closure permit for the Bear Creek Hydrogeologic Regime (permit number TNHW-116).

$$
\begin{aligned}
& \text { S3 = S-3 site point-of-compliance } \\
& \text { OLF = Oil Landfarm point-of-compliance } \\
& \text { BG = Eear Creck Burial Grounds/Walk-In Pits point-of-compliance } \\
& \mathrm{PB}=\text { Plume Boundary } \\
& 0 \text { = RCRA groundwater target constinuent for specified site } \\
& \text { - = RCRA groundwater triget constituent for specified site } \\
& \text { selected for quantitative trend analysis } \\
& \text {. = Not a RCRA groundwater target constituent }
\end{aligned}
$$

2. Referenced field aud laboratory methods and procedures are frots:

- American Society for Testing and Materials 1992. Annual Book of ASTM Standarts for Water and Waste Water.

- Commodore Advanced Sciences Team Environmental Data Acquisìion and Management Technical Procedures (R4) 2005

- EPA 1983. Methods for Chemical Analysis of Water and Wastes.

LSC = Liquid scintillation count

3. Project Quantitation Leve) (PQL) for undiluted groundwater samples, as specified in:

Bechtel Jacobs Company LLC. 2006. Sampling and Andtysis Plan for the Water Resources Restoration Program for Fiscal Year 2007 Oak Ridge Reservation Oak Ridge, Temessee, BJCJOR-2518, Bechtel Jacobs Company LLC, Oak Ridge, TN.

- In March 2007, an addendum to the above-referenced sampling and analysis plan (Addendum No. FY07-011) lowered the PQLs for several metals and VOCs that are RCRA groundwater target compounds. Analytical tesults for the groundwater samples collected during the second RCRA semianmal sampling ovent in CY 2007 reflect the lower PQLs. 
Table 9. Field measurements and RCRA groundwater target compounds for the Eastern S-3 Site Plume

\begin{tabular}{|c|c|c|c|c|}
\hline \multirow{2}{*}{ Measurement/Analyte } & \multicolumn{2}{|c|}{ Target Constituents } & \multirow{2}{*}{$\begin{array}{c}\text { Procednre/ } \\
\text { Analytical Method }{ }^{2}\end{array}$} & \multirow{2}{*}{$\mathbf{P Q L}^{3}$} \\
\hline & POC & $\overline{\mathbf{P B}}$ & & \\
\hline \multicolumn{5}{|l|}{ FUELD MEASUREMENTS } \\
\hline Depth to Water & . & - & EDAM-SAMP-0100 & NA \\
\hline Water Temperature & . & . & EDAM-SAMP-1203 & NA \\
\hline $\mathrm{pH}$ & . & . & EDAM-SAMP-1204 & NA \\
\hline Conductivity & . & . & EDAM-SAMP-1208 & $\overline{\mathrm{NA}}$ \\
\hline Dissolved Oxygen & . & . & EDAM-SAMP-1205 & $\overline{\text { NA }}$ \\
\hline Oxidation-Reduction Potential & . & . & EDAM-SAMP-1207 & NA \\
\hline Turbidity & - & . & EDAM-SAMP-1211 & NA \\
\hline \multicolumn{5}{|l|}{ INORGANICS (milligrams per liter) } \\
\hline Barium & 웅 & . & SW846-6010B & ).005 \\
\hline Cadmium & 0 & . & $\$ W 846-6010 \mathrm{~B}$ & $0.00013^{*}$ \\
\hline Chrotrium & 0 & . & SW846-6010B & 0.005 \\
\hline Mercury & 0 & . & SW846-7470 & 0.0002 \\
\hline Nickel & 은 & - & SW846-6010B & 0.01 \\
\hline Nitrate (as N) & $\bullet$ & . & EPA-353.2 & 0.1 \\
\hline Uranjum & o & . & $\begin{array}{l}\text { ASTM-DS174-M } \\
\text { SW846-6020A } \\
\text { EPA-907.0 [C] }\end{array}$ & 0.004 \\
\hline \multicolumn{5}{|l|}{ ORGANICS (micrograms per liter) } \\
\hline Acetone & o & + & $\$ W 846-8260$ & 5 \\
\hline Chloroform & $\bullet$ &. & SW846-8260 & 5 \\
\hline cis-1,2-Dichloroethene & o & $\dot{.}$ & SW846-8260 & 5 \\
\hline Methylene Chloride & $\circ$ & . & $\$ W 846-\$ 260$ & $2.5^{*}$ \\
\hline Tetrachloroethere & P &. & $\$ W 846-8260$ & $2.5^{*}$ \\
\hline Trichloroethene & o & - & SW846-8260 & $2.5^{*}$ \\
\hline \multicolumn{5}{|l|}{ RADIOANALYTES (picoCuries per liter) } \\
\hline Gross Alpha Activity & - & . & EPA-900.0 & $\overline{5}$ \\
\hline Gross Beta Activity & o & . & EPA-900.0 & 5 \\
\hline Technetiun-99 & $\bullet$ & o & LSC & 10 \\
\hline
\end{tabular}

Notes:

1. Groundwater target list constituent specified in the RCRA post-closure permit for the Upper East Fork Poplat Creek Hydrogeologic Regime (permit number TNHW-113).

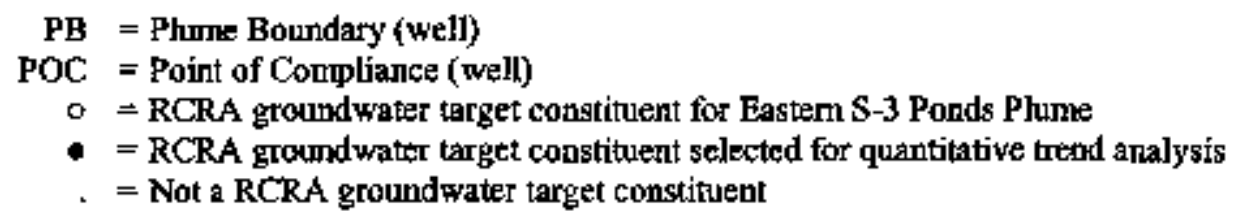




\section{Table 9 (continued)}

\section{Notes (continued):}

2. Referenced field and laboratory methods and procedures are from:

- American Society for Testing and Materials 1992. Antunl Book of ASTM Standards for Water and Waste Water

- Commodore Advanced Sciences Team Esvironmental Data Acquisition and Management Technical Procectures (R4) 2005

- EPA 1983. Methods for Chemical Analysis of Water and Wastes.

$[\mathrm{C}]=$ The total uranium concentration (mass) in samples from well GW-108 is calculated from isotopic results because the groundwater has very high calcium concentrations that cause interferences in the ASTM method.

LCS $=$ Liquid scintillation coumt

3. Project Quantitation LeveI (PQL) for undiluted groundwater samples, as specified in:

Bechtel Jacobs Company LLC. 2006. Sampling and Analysis Plan for the Water Resources Restoration Program for Fiscal Year 2007 Oak Ridge Reservation Oak Ridge, Tennessee, BJClOR-2518, Bechtel Jacobs Company LLC, Oak Ridge, TN.

- In March 2007, an addendurs to the above-referenced sampling and analysis plan (Addendum No. FYOT-0:1) lowered the PQLs for several metals and VOCS that are RCRA groundwater target compounds. Analytical results for the groumdwater samples collected during the second RCRA semiannual sampling event in CY 2007 reflect the lower PQLs. 
Table 10. Field neasurements and RCRA groundwater target compounds for the Chestnut Ridge Security Pits, Chestnut Ridge Sediment Disposal Basin, East Chestnut Ridge Waste Pile, and Kerr Hollow Quarry

\begin{tabular}{|c|c|c|c|c|c|c|}
\hline \multirow{2}{*}{ Field Measurements } & \multicolumn{4}{|c|}{ Target Constituents ${ }^{1}$} & \multirow{2}{*}{$\begin{array}{c}\text { Procedurel } \\
\text { Analytical Method }^{2}\end{array}$} & \multirow{2}{*}{$\mathrm{PQL}^{3}$} \\
\hline & CRSP & CRSDB & ECRWP & $\mathrm{KHQ}$ & & \\
\hline Depth to Water & - &. &. & . & EDAM-SAMP-0100 & NA \\
\hline Water Temperature & $\therefore$ & . & $\therefore$ & . & EDAM-SAMP-1203 & $\mathrm{NA}$ \\
\hline $\mathrm{pH}$ & $\therefore$ & . & . & 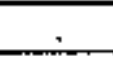 & EDAM-SAMP-1204 & NA \\
\hline Conductivity & $\therefore$ & . & . &. & EDAM-SAMP-1208 & NA \\
\hline Dissolved Oxygen & . & . & . & . & EDAM-SAMP-1205 & NA \\
\hline Oxjdation-Reduction Potential & & . & . & - & EDAM-SAMP-1207 & NA \\
\hline Turbidity & & . & . & . & EDAM-SAMP-12!1 & $\overline{\mathrm{NA}}$ \\
\hline \multirow{2}{*}{$\begin{array}{c}\text { Inorganies } \\
\text { (milligrams per liter) }\end{array}$} & \multicolumn{4}{|c|}{ Target Constiturents } & \multirow{2}{*}{$\begin{array}{c}\text { Procedure' } \\
\text { Analytical Method }^{2}\end{array}$} & \multirow{2}{*}{$\mathbf{P Q L}^{3}$} \\
\hline & CRSP & CRSDB & ECRWP & $\mathrm{KHQ}$ & & \\
\hline Antimony & & . & 0 & 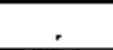 & SW846-6010B & $0.003^{*}$ \\
\hline Arsentic & 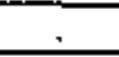 & . & 0 & . & SW846-6010B & 0.005 \\
\hline Barium & . & . & 0 & + & SW846-6010B & 0.005 \\
\hline Boron & . & . & 0 & . & SW846-6010B & 0.01 \\
\hline Cadmium & 0 & 0 & 0 & 0 & SW846-6010B & $0.00013^{*}$ \\
\hline Chromium & 0 & 0 & 0 & O & SW846-6010B & 0.005 \\
\hline Chloride & $\dot{.}$ & . & 0 & 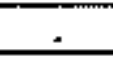 & $\mathrm{EPA}-300.0$ & 0.1 \\
\hline Cobalt & . & $\therefore$ & $\circ$ & $\therefore$ & SW846-6010B & 0.005 \\
\hline Copper & $\therefore$ & . & 으 & 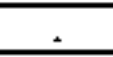 & SW846-6010B & 0.005 \\
\hline Iron & . & . & 0 & . & SW846-6010B & 0.01 \\
\hline Lead & & 0 & 0 & 0 & SW846-6010B & $0.002 *$ \\
\hline Lithium & $\dot{.}$ & $\therefore$ & $\circ$ &. & SW846-6010B & 0.01 \\
\hline Manganese & $\therefore$ &. & 0 & . & SW846-6010B & 0.005 \\
\hline Mercury & 0 & 0 & 0 & $a$ & SW $\$ 46.7470$ & 0.0002 \\
\hline Nickel & 9 & 0 & 0 & 0 & SW846-6010B & 0.01 \\
\hline Nitrate (as N) & . & . & 0 & . & $\mathrm{EPA}-353,2$ & 0.1 \\
\hline Selenum & . &. & 0 & . & SW846-6010B & $0.0025^{*}$ \\
\hline Silver & . & 0 & . & . & EPA-353.2 & $0.10025^{*}$ \\
\hline Sulfate & $\therefore$ &. & 0 &. & \$W846-6010B & \\
\hline Thallium & 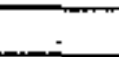 & . & 9 & . & SW846-6010B & $0.001 *$ \\
\hline Uranium & $\circ$ & 0 & 0 & 0 & $\begin{array}{l}\text { ASTM-D5174-97 or } \\
\text { SW846-6020A }\end{array}$ & 0.004 \\
\hline Zinc & 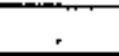 & . & 0 & . & & \\
\hline \multirow{2}{*}{$\begin{array}{c}\text { Organies } \\
\text { (micrograms per liter) }\end{array}$} & \multicolumn{4}{|c|}{ Target Constituents ${ }^{1}$} & \multirow{2}{*}{$\begin{array}{c}\text { Procedure/ } \\
\text { Anglytical Methodi }^{2}\end{array}$} & \multirow{2}{*}{$\mathbf{P Q L}^{3}$} \\
\hline & CRSP & CRSDB & ECRWP & KHQ & & \\
\hline Berzene & 은 & . & 0 &. & SW846-8260 & $2.5^{*}$ \\
\hline Bromoform & 0 & - & . & $\therefore$ & SW846-8260 & 5 \\
\hline Carbon Tetrachloride & 0 & . & $\circ$ & $\circ$ & SW846-8260 & $2.5^{*}$ \\
\hline Chloroform & 0 & $\therefore$ & 0 & 0 & SW846-8260 & 5 \\
\hline Chloroethane $^{\text {** }}$ & . & . & 0 & . & SW846-8260 & 10 \\
\hline
\end{tabular}


Table 10 (continued)

\begin{tabular}{|c|c|c|c|c|c|c|}
\hline \multirow{2}{*}{$\begin{array}{c}\text { Orgaries } \\
\text { (micrograms per liter) }\end{array}$} & \multicolumn{4}{|c|}{ Target Constituents' $^{\prime \prime}$} & \multirow{2}{*}{$\begin{array}{c}\text { Proceduref } \\
\text { Analytical Method }{ }^{2}\end{array}$} & \multirow{2}{*}{$\mathbf{P Q L}^{3}$} \\
\hline & CRSP & CRSDB & ECRWP & $\mathrm{KHQ}$ & & \\
\hline 1,1-Dichloroethane & $\bullet$ & $\therefore$ & 0 & . & SW846-8260 & 5 \\
\hline 1,2-Dichloroethane & o & - & 0 & 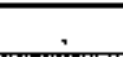 & SW846-8260 & $2.5^{*}$ \\
\hline 1,1-Dichloroethene & o & . & 0 & . & SW846-8260 & $3.5^{*}$ \\
\hline cis-1,2-Dichloroethene & o &. & $\circ$ & . & SW846-8260 & 5 \\
\hline trans-1,2-Dichloroethene & a & - & 0 & + & SW846-8260 & 5 \\
\hline 1,1,1-Trichloroethane & 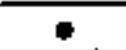 & . & 0 & & SW846-8260 & 5 \\
\hline Methylene Chloride & . & . & 0 & - & SW846-8260 & $2.5^{*}$ \\
\hline Tetrachloroethene & 0 & . & 으 & 0 & SW846-8260 & $2,5^{n}$ \\
\hline Trichloroethene & p & , & 0 & + & SW846-8260 & $2.5^{*}$ \\
\hline Viny] chloride & o & . & Q & - & SW846-8260 & $1^{*}$ \\
\hline \multirow{2}{*}{$\begin{array}{c}\text { Radioanglytes } \\
\text { (picoCuries per liter) }\end{array}$} & \multicolumn{4}{|c|}{ Target Constituents 1} & Procedure/ & pOt $^{3}$ \\
\hline & CRSP & CRSDB & ECRWP & KHQ & Analytlcal Method ${ }^{2}$ & PQL \\
\hline Gross Alpha Activity & 0 & $\sigma^{\circ}$ & a & a & EPA-900,0 & 5 \\
\hline Gross Beta Activity & $\circ$ & . & . & $\overline{0}$ & EPA-900,0 & 5 \\
\hline
\end{tabular}

Notes:

1. Groundwater target compound specified in the RCRA post-closure permit for the

Chestmut Ridge Hydrogeologic Regime (permit number TNHW-128).

CRSP = Chestout Ridge Security Pits

CRSDB $=$ Chestaut Ridge Sediment Disposal Basin

ECRWP = East Chestnut Ridge Waste Pile

KHQ $=$ Kerr Hollow Quarry

0 = RCRA groundwater target constituent for specified site

- = RCRA groundwater target constituent sekected for quantitative trend analysis

= Not a RCRA groumdwater target constituent

** = Because of a typographical error, the PCP incorrectly identifies chloromethene inslead of chloroethane as a RCRA ground water target compound (see Sect 6).

2. Referenced field and laboratory methods and procedures are from:

- American Saciety fot Testing and Materials 1992. Annual Book of ASTM Standards for Water and Waste Water.

- Commodore Ad̛varced Sciences Team Environmental Data Acquisition and Management Technical Procedures (R4) 2005

- EPA 1983. Methods for Chemical Analysis of Water and Wastes.

3. Project Quantitation Level (PQL) for undiluted groundwaler samples, as specified in:

Bechtel Jacobs Company LLC. 2005. Sampling and Analysis Plan for the Water Resources Restoration

Program far Fiscal Year 2007 Oak Ridge Reservation Oak Ridge, Tennessee, BJCIOR-2518,

Bechtel Jacobs Company LI.C, Oak Ridge, TN.

- In March 2007, an addendum to the above-referenced sampling and analysis plan (Addencuun No.

FY07-011) lowered the PQLs for several metals and VOCs that are RCRA groundwater target compounds. Analytical results for the groundwater sarmples collected dering the second RCRA semiannual sactipling event in CY 2007 teflext the lower PQLs. 
Table 11. Laboratory blanks and trip blanks associated with CY 2097 RCRA post-closure groundwater monitoring at the Y-12 National Security Complex

\begin{tabular}{|c|c|c|c|c|c|}
\hline \multirow{2}{*}{ Sampling Point ${ }^{1}$} & \multirow{2}{*}{\multicolumn{2}{|c|}{$\begin{array}{c}\text { TSD Unit } \\
\text { Sampling Purpose }\end{array}$}} & \multirow{3}{*}{$\begin{array}{c}\begin{array}{c}\text { Date } \\
\text { Samoled }\end{array} \\
01 / 02 / 07\end{array}$} & \multicolumn{2}{|c|}{ Sample Number } \\
\hline & & & & Trip Blank & Laboratory Blank \\
\hline GW.008 & DLF & $\mathrm{POC}$ & & Y020816-TB & 07LVG008-MB 1 \\
\hline GW-008 & OLF & $\mathrm{POC}$ & $07 / 02 / 07$ & Y021068-TB & 07LVG087-MB1 \\
\hline GW-046 & BG & POC & $01 / 03 / 07$ & Y020818-TB & O7LVG006-MB \\
\hline GW-046 & BG & POC & $01 / 03 / 07$ & Y020818-TB & 07LVG010-MB1 \\
\hline GW-046 & $\mathrm{BG}$ & POC & $07 / 02 / 07$ & Y021065-TB & 07LVG087-MBI \\
\hline GW-046 & BG & POC & $07 / 02 / 07$ & $\mathrm{Y} 021065-\mathrm{rB}$ & 07LVG087-MBI \\
\hline GW-108 & \$3 East & POC & $01 / 04 / 07$ & Y020890-TB & O7LVG010-MB1 \\
\hline GW-108 & S3 East & POC & $07 / 10 / 07$ & Y021077-TB & 07LVG093-MB1 \\
\hline GW-143 & $\mathrm{KHQ}$ & POC & $01 / 0807$ & Y020894-TB & 07LVX009-MB1 \\
\hline GW.144 & KHQ & $P Q C$ & $01 / 04 / 07$ & Y020886-TB & $07 \mathrm{LVX} \times 008-\mathrm{MB} 1$ \\
\hline GW-145 & KHQ & POC & $01 / 08 / 07$ & Y020896-TB & $07 L V X 009-\mathrm{MB} 1$ \\
\hline$G W-161$ & ECRWP & $\mathrm{POC}$ & $01 / 25 / 07$ & Y020906-TB & 07LVX030-MB] \\
\hline GW-161 & ECRWP & $P Q C$ & $07 / 10 / 07$ & Y021082-TB & 07LVGO94MB1 \\
\hline GW-177 & CRSP & POC & $01 / 09 / 07$ & Y020902-TB & 07LVX009-MB] \\
\hline GW-177 & CRSP & $P O C$ & $07 / 1109$ & Y021081-TB & 07LVE076-MB1 \\
\hline GW-231 & $\mathrm{KHQ}$ & UPG & $01 / 04 / 07$ & Y020886-TB & 07LVX008-MB1 \\
\hline GW-231 & $\mathrm{KHQ}$ & UPG & $01 / 04 / 07$ & Y020886-TB & 07LVX008-MB1 \\
\hline$G W-276$ & S3 & $\mathrm{POC}$ & $01 / 03 / 07$ & Y020819-TB & 07LVG010-MBI \\
\hline GW-276 & S3 & POC & $07 / 09 / 07$ & $\mathrm{Y} 021071-\mathrm{TB}$ & $07 L V G 097 \mathrm{MB} 1$ \\
\hline GW-292 & ECRWP & POC & $01 / 23 / 07$ & Y020907-TB & 07LVG024-MB1 \\
\hline GW-292 & ECRWP & $\mathrm{POC}$ & $0 / / 10 / 07$ & Y021083-TB & 07LVG094-MB1 \\
\hline GW-293 & ECRWP & POC & $01 / 24 / 07$ & Y020908-TB & 07LVX030-MB1 \\
\hline GW-293 & ECRWP & $\mathrm{POC}$ & $01 / 24 / 07$ & Y020908-TB & 07LVX030-MB1 \\
\hline GW-293 & ECRWP & POC & $07 / 10 / 07$ & Y021084-TB & 07LVG097-MB1 \\
\hline GW-293 & ECRWP & POC & $07 / 10 / 07$ & Y021084-TB & 0?LVG097-MBI \\
\hline$G W-294$ & ECRWP & UPG & $01 / 22 / 07$ & Y020910-TB & 07LVX024-MB1 \\
\hline GW-294 & ECRWP & UPG & $07 / 1107$ & Y021081-TB & 07LVE076-MB1 \\
\hline GW-296 & ECRWP & $\mathrm{POC}$ & $01 / 22 / 07$ & Y020910-TB & 07LVX024-ME! \\
\hline GW-296 & ECRWP & POC & $07 / 10 / 07$ & Y021083-TB & 07LVG098-MBL \\
\hline GW-298 & ECRWP & POC & $01 / 29 / 07$ & Y020912-TB & 07LVX032-MBI \\
\hline GW-298 & ECRWP & POC & $07 / 09 / 07$ & Y021088-TB & 07LVG094-MB1 \\
\hline GW-301 & CRSP & PB & $01 / 09 / 07$ & Y020903-TB & $07 \mathrm{LVX} 010-\mathrm{MB} 1$ \\
\hline GW-30I & CRSP & PB & DL/09/07 & Y020903-TB & 07LVX010-MB1 \\
\hline GW-301 & CRSP & $\mathrm{PB}$ & $07 / 12 / 07$ & Y021079-TB & 07LVE079-MBI \\
\hline GW-301 & CRSP & PB & $07 / 12 / 07$ & Y021079-TB & 07LVE079-MB1 \\
\hline GW-521 & CRSP & UPG & $01 / 10 / 07$ & LF02231 & D7A170000443B \\
\hline$G W-521$ & $\mathrm{CRSP}$ & UPG & $07 / 12 / 07$ & LF02391-TB & D7G250000664B \\
\hline GW-557 & CRSP & PB & $01 / 11 / 07$ & LF02361 & D7A230000381B \\
\hline GW-557 & CRSP & PB & $07 / 16 / 07$ & LF02395-TB & $\mathrm{D} 7 \mathrm{G} 260000582 \mathrm{~B}$ \\
\hline GW-562 & CRSP & PB & $01 / 16 / 07$ & LFo2325 & $\mathrm{D} 7 \mathrm{~A} 290000094 \mathrm{~B}$ \\
\hline$G W-562$ & CRSP & PB & $07 / 17 / 07$ & LF02403-TB & D7G310000182B \\
\hline
\end{tabular}


Table 11 (continued)

\begin{tabular}{|c|c|c|c|c|c|}
\hline \multirow{2}{*}{ Sampling Point' } & \multirow{2}{*}{\multicolumn{2}{|c|}{$\begin{array}{c}\text { TSD Unit } / \\
\text { Sampling Purpose }\end{array}$}} & \multirow{3}{*}{$\begin{array}{c}\text { Date } \\
\text { Sampled }\end{array}$} & \multicolumn{2}{|c|}{ Sample Number } \\
\hline & & & & Trip Blank & Laborafory Blank \\
\hline $\mathrm{GW} \cdot 712$ & EXP & PB & & Y020813-TB & 07LVGO0B-MB1 \\
\hline GW.712 & EXP & PB & $07 / 02 / 07$ & $\mathrm{YO2J065- \textrm {TB }}$ & 07LVG087 $\mathrm{AB}$ \\
\hline GW-713 & EXP & PB & $01 / 02 / 07$ & Y020813-TB & 07LVG006-MBl \\
\hline GW-713 & EXP & PB & $01 / 02 / 07$ & Y020813-TB & D7LVG006-MBl \\
\hline GW-713 & EXP & PB & $07 / 03 / 07$ & Y021066-TB & 07LVG093-MB] \\
\hline GW-713 & EXP & PB & $07 / 03 / 07$ & Y021066-TB & 07LVG093-MB1 \\
\hline GW-714 & EXP & PB & $01 / 02 / 07$ & Y020816-TE & 07LVG006-MB] \\
\hline GW-714 & EXP & PB & $07 / 02 / 07$ & $\mathrm{Y} 021068-\mathrm{TB}$ & 07LVG087-MB] \\
\hline GW-79g & CRSP & PB & $01 / 16 / 07$ & LF02284 & D7A290000094B \\
\hline GW.799 & CRSP & $\mathrm{PB}$ & $07 / 17 / 07$ & LF02401-TB & D7G310000182B \\
\hline GW-801 & CRSP & $\mathrm{PB}$ & $01 / 1107$ & $\mathrm{LF02277}$ & D7A2300003818 \\
\hline GW-801 & CRSP & PB & $07 / 1607$ & LFO2390-TB & D7G2600000582B \\
\hline GW-831 & CRSP & PB & $01 / 09 / 07$ & Y020902-TB & $07 \mathrm{LVX} 009-\mathrm{MBI}$ \\
\hline GW-831 & CRSP & $P B$ & $07 / 11 / 07$ & Y02!078-TE & 07LVE076-MB1 \\
\hline SCR4.3SP & CRSP & $P B$ & $01 / 16 / 07$ & LF02284 & D7A290000094B \\
\hline SCR4.3Sp & CRSP & PB & $07 / 1707$ & [F0240]-TB & D7G310000182B \\
\hline SS-6 & EXP & PB & $01 / 03 / 07$ & Y020820-TB & 07LVG008-MB1 \\
\hline SS-6 & EXP & PB & $07 / 02 / 07$ & Y021089-TB & 07LVG087-MB1 \\
\hline
\end{tabular}

Notes:

1. Dil = Sample diluted for analysis

Dup = Duplicate samole

2. BCBG/WIP = Bear Creck Burial Grounds/Walk-In Pits

CRSDB $=$ Chestmut Ridge Sediment Disposal Basin

CRSP $=$ Chestnot Ridge Security Pits

East S3 $=$ Eastern S-3 Ponds Plume

ECRWP $=$ East Chestmut Riuge Waste Pik

$\mathrm{KHQ}=$ Kerr Holkow Quany

OLF $\quad$ Oil Landfarm

PB = plume boundary

$\mathrm{POC}=$ point of compliance

S3 $=$ S-3 Site 
Table 12. Volatile organic compounds detected in laboratory blanks and trip blanks associated with CY 2007 RCRA post-closure groundwater monitorIng at the

\section{Y-12 National Security Complex}

\begin{tabular}{|c|c|c|c|}
\hline \multicolumn{2}{|c|}{$\begin{array}{c}\text { QA/QC Sample Type } \\
\text { and Number }\end{array}$} & \multirow{2}{*}{$\frac{\text { Compound }}{\text { 2-Hexanone }}$} & \multirow{2}{*}{$\begin{array}{c}\text { Concentration }(\mathrm{kg} / \mathrm{L}) \\
0.1 \mathrm{~J} \\
\end{array}$} \\
\hline Laboratory Blanks & 07LVE076-MBI & & \\
\hline & 07LVG006-MBI & 2-Butanone & $3 \mathrm{~J}$ \\
\hline & 07LVG006-MB1 & Acetone & $2 \mathrm{~J}$ \\
\hline & 07LVG006-MB1 & Methylene chloride & $3 \mathrm{~J}$ \\
\hline & 07LVG008-MB1 & 2-Butanone & $3 \mathrm{~J}$ \\
\hline & 07LVG008-MBI & Acetone & $2 \mathrm{~J}$ \\
\hline & 07LVG008-MBI & Methylene chloride & $3 \mathrm{~J}$ \\
\hline & 07LVG010-MB1 & 2-Butanone & $3 \mathrm{~J}$ \\
\hline & 07LVGO10-MB1 & Acetone & 21 \\
\hline & 07LVGO10-MBI & Methylene chlotide & 5 \\
\hline & 07LVG024-MB1 & Acetone & $3 \mathrm{~J}$ \\
\hline & 07LVG024-MB1 & Methylene chloride & $2 \mathrm{~J}$ \\
\hline & 07LVG087-MB1 & Methylene chionide & $1 \mathrm{~J}$ \\
\hline & 07LVG093-MB1 & Methylene chioride & $1 \mathrm{~J}$ \\
\hline & 07LVG094-MB1 & Methylene chloride & $0.7 \mathrm{~J}$ \\
\hline & 07LVG097-MB1 & Methylete chloride & $1 \mathrm{~J}$ \\
\hline & 07LVG097-MB1 & Total Xylene & $1 \mathrm{~J}$ \\
\hline & 07LVG098-MB1 & Methylene chloride & $0.9 \mathrm{~J}$ \\
\hline & 07LVX008-MB1 & Methyleoe chioride & $4 J$ \\
\hline & $07 \mathrm{LVX009} \mathrm{MBl}$ & Methylene chloride & 45 \\
\hline & $07 t V \times 0 ! 0-M B 1$ & Methylene chloride & $5 \mathrm{~J}$ \\
\hline & 07LVX024-MB1 & Acetone & $2 \mathrm{~J}$ \\
\hline & 07LVX024-MB1 & Methylene chloride & $1 \mathrm{~J}$ \\
\hline & $07 \mathrm{LVX030- \textrm {MB } 1}$ & Acetone & $3 \mathrm{~J}$ \\
\hline & 07LVX030-MB1 & Methylene chloride & $1 \mathrm{~J}$ \\
\hline & 07LVX032-MB 1 & Methylene chloride & $2 \mathrm{~J}$ \\
\hline & D7A230000381B & Acetone & $2.2 \mathrm{~J}$ \\
\hline & D7A290000094B & Acetone & $1.9 \mathrm{~J}$ \\
\hline & D7G260000582B & Acetone & $2 \mathrm{~J}$ \\
\hline
\end{tabular}


Table 12 (continned)

\begin{tabular}{|c|c|c|c|}
\hline \multicolumn{2}{|c|}{$\begin{array}{c}\text { QAVC Sample Type } \\
\text { and Number }\end{array}$} & \multirow{2}{*}{$\begin{array}{l}\text { Compound } \\
\text { 1,4-Dichlorobenzene }\end{array}$} & \multirow{2}{*}{$\frac{\text { Concentration }(\mu \mathrm{g} / \mathrm{L})^{\prime}}{0.87 \mathrm{~J}}$} \\
\hline \multirow[t]{42}{*}{ Trip Blanks } & LF02231 & & \\
\hline & LF02231 & Acetone & $9.7 \mathrm{~J}$ \\
\hline & LF02231 & Ethylbenzene & $0.2 \mathrm{~J}$ \\
\hline & LFo2231 & Toluene & $0.52 \mathrm{~J}$ \\
\hline & $\mathrm{LF} 02277$ & 1,4-Dichlorobenzene & $0.53 \mathrm{~J}$ \\
\hline & LF02277 & Acetone & 12 \\
\hline & $\mathrm{LF} 02277$ & Ethylbenzene & $0.26 \mathrm{~J}$ \\
\hline & $\mathrm{LF} 02277$ & Toluene & $0.47 \mathrm{~J}$ \\
\hline & LF02284 & 1,4-Dichlorobenzenc & $0.83 \mathrm{~J}$ \\
\hline & LF02284 & 2-Butanone & $3.5 \mathrm{~J}$ \\
\hline & LF02284 & Acetone & 11 \\
\hline & LF02284 & Toluene & $0.35 \mathrm{~J}$ \\
\hline & LF02325 & 1,4-Dichlorobernzene & $0.83 \mathrm{~J}$ \\
\hline & LF02325 & 2-Butanone & $3 \mathrm{~J}$ \\
\hline & LF02325 & Acetone & 11 \\
\hline & LF02325 & Toluene & $0.34 \mathrm{~J}$ \\
\hline & LF02361 & I,4-Dichlorobenzene & $0.65 \mathrm{~J}$ \\
\hline & LF02361 & 2-Butanohe & $3.3 \mathrm{~J}$ \\
\hline & LF02361 & Acetone & 11 \\
\hline & LF02361 & Ethylbenzene & $0.31 \mathrm{~J}$ \\
\hline & LF0236] & Toluetes & $0.52 \mathrm{~J}$ \\
\hline & LF02390-TB & 1,4-Dichlorobenzene & $0.31 \mathrm{~J}$ \\
\hline & LF02390-TB & Bromoform & $1.5 \mathrm{~J}$ \\
\hline & LF02390-TB & Chloroform & $0.17 \mathrm{~J}$ \\
\hline & LF0239]-TB & 1,4-Dichlotobenzene & $0.21 \mathrm{~J}$ \\
\hline & LF0239]-TB & Bromoform & $1.7 \mathrm{~J}$ \\
\hline & LF02391-TB & Dibromochloromethane & $0.34 \mathrm{~J}$ \\
\hline & LF02395-TB & 1,4-Dichlorobenzene & $0.28 \mathrm{~J}$ \\
\hline & LF02395-TB & Toluene & $0.21 \mathrm{~J}$ \\
\hline & LF0240]-TB & Chloromethane & ] J \\
\hline & LF02401-TB & Styrene & $0.38 \mathrm{~J}$ \\
\hline & LFO2401-TB & Toluene & $0.56 \mathrm{~J}$ \\
\hline & LF02403-TB & Toluente & $0.51 \mathrm{~J}$ \\
\hline & Y020813-TB & 2-Butabone & $3 \mathrm{~J}$ \\
\hline & Y020813-TB & Acetone & $2 J$ \\
\hline & Y020813-TB & Methyiene chloride & $3 \mathrm{~J}$ \\
\hline & Y020816-TB & 2-Butanone & 4J \\
\hline & Y020816-TB & Acetone & $3 \mathrm{~J}$ \\
\hline & Y020816-TB & Methylene chloride & $3 \mathrm{~J}$ \\
\hline & Y020818-TB & 2-Butanone & $4 \mathrm{~J}$ \\
\hline & Y020818-TB & Acetone & 33 \\
\hline & Y020818-TB & Methylene chloride & $3 \mathrm{~J}$ \\
\hline
\end{tabular}


Table 12 (continned)

\begin{tabular}{|c|c|c|c|}
\hline \multicolumn{2}{|c|}{$\begin{array}{l}\text { QA/QC Somple Type } \\
\text { and Number }\end{array}$} & \multirow{2}{*}{$\frac{\text { Compound }}{\text { 2-Butanone }}$} & \multirow{2}{*}{$\frac{\text { Concentration }(\mu \mathrm{g} / \mathrm{L})^{\mathrm{J}}}{4 \mathrm{~J}}$} \\
\hline Trip Blarks & Y020819-TB & & \\
\hline & Y020819-TB & Acetone & $3 \mathrm{~J}$ \\
\hline & Y020819-TB & Methylene chloride & $3 \mathrm{~J}$ \\
\hline & Y020820-TB & 2-Butanone & $3 \mathrm{~J}$ \\
\hline & Y020820-TB & Acetone & $2 \mathrm{~J}$ \\
\hline & Y020B20-TB & Methylene chloride & $4 \mathrm{~J}$ \\
\hline & Y020886-TB & Methylene chlonide & $1 \mathrm{~J}$ \\
\hline & Y020890-TB & 2-Butamone & $4 \mathrm{~J}$ \\
\hline & Y020890-TB & Acetonte & $2 J$ \\
\hline & Y020890-TB & Methylene chloride & $3 J$ \\
\hline & Y020903-TB & Methylene chlonids & 13 \\
\hline & Y020906-TB & Metbylene chloride & $2 \mathrm{~J}$ \\
\hline & Y020907-TB & 1,1,2,2-Tetracbloroethane & $1 \mathrm{~J}$ \\
\hline & Y020907-TB & 2-Butanone & $4 \mathrm{~J}$ \\
\hline & Y020907-TB & Acctone & 12 \\
\hline & Y020907-TB & Methylene chloride & $3 \mathrm{~J}$ \\
\hline & Y020908-7B & Acetone & $5 \mathrm{~J}$ \\
\hline & Y020908-TB & Metbylene chloride & $1 \mathrm{~J}$ \\
\hline & Y020910-TB & Acetone & 12 \\
\hline & Y020910-TB & Methylene chloride & $4 \mathrm{~J}$ \\
\hline & Y020912-TB & Metbylene chloride & $2 \mathrm{~J}$ \\
\hline & Y021065-TB & Methylene chloride & $1 \mathrm{~J}$ \\
\hline & Y021066-TB & Acetone & $7 \mathrm{~J}$ \\
\hline & Y021066-TB & Methylene chloride & $1 \mathrm{~J}$ \\
\hline & Y021068-TB & Acetone & $6 \mathrm{~J}$ \\
\hline & Y021068-TB & Methylene chloride & $1 \mathrm{~J}$ \\
\hline & Y021071-TB & Acetone & $3 \mathrm{~J}$ \\
\hline & Y021071-TB & Metbylene chloride & 3 \\
\hline & Y021077-TB & Acetone & $2 \mathrm{~J}$ \\
\hline & Y021077-TB & Methylene chloride & $1 \mathrm{~J}$ \\
\hline & Y021082-TB & Acetone & $2 \mathrm{~J}$ \\
\hline & $\mathrm{Y} 021082-\mathrm{TB}$ & Methylene chloride & 3 \\
\hline & Y021083-TB & Acetone & $2 \mathrm{~J}$ \\
\hline & Y021083-TB & Methylene chloride & $1 \mathrm{~J}$ \\
\hline & Y021084-TB & Methylene chloride & $1 \mathrm{~J}$ \\
\hline & Y021089-TB & Acetone & $6 J$ \\
\hline
\end{tabular}

Notes:

1. All results in micrograms per liter $(\mu \mathrm{g} / \mathrm{L})$.

$\mathrm{J}=$ Estimated concentration. 
Table 13. Depth-to-water measurements and groundwater elevations for selected wells in the Bear Creek Hydroge日logic Regime, April 2007

\begin{tabular}{|c|c|c|c|c|c|c|c|}
\hline \multirow{2}{*}{$\begin{array}{c}\text { Well } \\
\text { Number }\end{array}$} & \multirow{2}{*}{ Location $^{2}$} & \multicolumn{2}{|c|}{ Hydrogeologic Unit } & \multirow{2}{*}{$\begin{array}{c}\text { Measuring } \\
\text { Point }^{3}\end{array}$} & \multirow{2}{*}{$\begin{array}{c}\text { Bate } \\
\text { Measured }\end{array}$} & \multirow{2}{*}{$\begin{array}{l}\text { Depth to } \\
\text { Water }\end{array}$} & \multirow{2}{*}{$\begin{array}{l}\text { Groundwater } \\
\text { Elevation }^{5}\end{array}$} \\
\hline & & Aquifer & Aquitard & & & & \\
\hline GW-001 & OLF & & 0 & 981,00 & $04 / 12 / 07$ & 14.95 & 966.05 \\
\hline GW-008* & OLF & & $\theta$ & 965.39 & $04 / 12 / 07$ & 14.30 & 951.09 \\
\hline $\mathrm{GW}-010$ & OLF & & 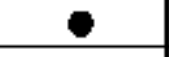 & 952.70 & $04 / 12 / 07$ & 3.26 & 949.44 \\
\hline $\mathrm{GW}-012$ & OLF & & 0 & 955.57 & $04 / 12 / 07$ & 6.50 & 949.07 \\
\hline $\mathrm{GW}-013$ & OLF & & - & 965.14 & $04 / 12 / 07$ & 5.93 & 959.21 \\
\hline GW-014 & $\mathrm{BG}$ & & - & 934.50 & $04 / 10 / 07$ & 6.51 & 927.99 \\
\hline GW-016 & $\mathbf{B G}$ & & 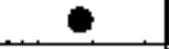 & 928.81 & $04 / 10 / 07$ & 10.24 & 918.57 \\
\hline $\mathrm{OW}=04 !$ & $\underline{B G}$ & & + & 1008.10 & $04 / 10 / 07$ & 15.58 & 992.52 \\
\hline$G W=046^{* 1}$ & $\mathrm{BO}$ & & e & 921.17 & $04 / 10 / 07$ & 3.96 & 917.21 \\
\hline $\mathrm{GW}-047$ & $\mathrm{BG}$ & & - & 929.00 & $04 / 10 / 07$ & 7.80 & 921.20 \\
\hline $0 w-052$ & BG & 9 & & 905.70 & $04 / 10 / 07$ & 14.16 & 891.54 \\
\hline $\mathrm{GW}-053$ & $\mathrm{BG}$ & e & & 903,42 & $04 / 10 / 07$ & 8.67 & 894.75 \\
\hline$G W-065$ & OLF & $\theta$ & & 982.50 & $04 / 16 / 07$ & 22.78 & 959.72 \\
\hline GW-080 & BG & & - & 981.00 & $04 / 10 / 07$ & 21.86 & 959.14 \\
\hline GW-084 & OLF & & - & 997.18 & $04 / 16 / 07$ & 9.90 & 987.28 \\
\hline GW-086 & OLF & & e & 982.80 & $04 / 16 / 07$ & $\$ 1.66$ & 971.14 \\
\hline GW-090 & $\mathrm{BG}$ & & e & 961.88 & $04 / 10 / 07$ & 5.28 & 956.60 \\
\hline GW-091 & BG & & - & 952.62 & $04 / 10 / 07$ & 7.75 & 944.87 \\
\hline GW-097 & OLF & & - & 945.41 & $04 / 1207$ & 9.42 & 935.99 \\
\hline GW-100 & $\mathrm{s} 3$ & 는 & & 987.40 & $04 / 09 / 07$ & 5.95 & 981.45 \\
\hline GW-10I & $\$ 3$ & & - & 1007.40 & $04 / 09 / 07$ & 9.31 & 998.09 \\
\hline GW-115 & $\$ 3$ & & $\bullet$ & 1055.01 & $04 / 10 / 07$ & 11.57 & 1043.44 \\
\hline GW-127 & $\$ 3$ & & 0 & 1005.90 & $04 / 09 / 07$ & 13.34 & 992.06 \\
\hline GW-236 & $\mathrm{S} 3$ & 는 & & 983.21 & $04 / 16107$ & 8.31 & 974.90 \\
\hline GW-242 & $\mathrm{BG}$ & & 은 & 978.69 & $04 / 10 / 07$ & 5,91 & 972.78 \\
\hline GW-245 & S3 & & 0 & 1009.08 & $04 / 09 / 07$ & 13.40 & 995.68 \\
\hline GW-249 & BG & & 0 & 991.15 & $04 / 10 / 07$ & 35.89 & 955.26 \\
\hline GW-257 & $\mathrm{BG}$ & & 0 & 961.68 & $04 / 10 / 07$ & 28.81 & 932.87 \\
\hline GW-276* & $\$ 3$ & & 0 & 1001.57 & $04 / 10 / 07$ & 6.84 & 994.73 \\
\hline GW-287 & $\mathrm{BG}$ & & 9 & 927.04 & $04 / 10 / 07$ & 9.29 & 917.75 \\
\hline GW-289 & BG & & 0 & 948.73 & $04 / 10 / 07$ & 16.71 & 932.02 \\
\hline GW-291 & $\mathrm{BG}$ & & 0 & 948.66 & $04 / 10107$ & 11.53 & 937.13 \\
\hline GW.307 & RS & 0 & & 993.14 & $04 / 09 / 07$ & 30.45 & 962.69 \\
\hline GW-309 & $\mathrm{RS}$ & - & & 988.17 & $04 / 09 / 07$ & 20.67 & 967.50 \\
\hline GW-310 & RS & 0 & & $995 . \$ 2$ & $04 / 09 / 07$ & 21.46 & 974.06 \\
\hline GW-316 & SPL. & 0 & & 1047.17 & $04 / 10 / 07$ & 57.98 & 989.19 \\
\hline GW-323 & SPI & 둔 & & 1130.11 & $04 / 16 / 07$ & 85.87 & 1044.24 \\
\hline
\end{tabular}


Table 13 (continued)

\begin{tabular}{|c|c|c|c|c|c|c|c|}
\hline \multirow{2}{*}{$\begin{array}{c}\text { Well } \\
\text { Namuler }^{t}\end{array}$} & \multirow{2}{*}{ Location ${ }^{2}$} & \multicolumn{2}{|c|}{ Hydrageologic Unit } & \multirow{2}{*}{$\begin{array}{c}\text { Measuring } \\
\text { Point }^{3}\end{array}$} & \multirow{2}{*}{$\begin{array}{c}\text { Date } \\
\text { Meosured }\end{array}$} & \multirow{2}{*}{$\begin{array}{c}\text { Depth to } \\
\text { Water }\end{array}$} & \multirow{2}{*}{$\begin{array}{l}\text { Groundwater } \\
\text { Elevation }\end{array}$} \\
\hline & & Aquiler & Aquilard & & & & \\
\hline GW-325 & 53 & & 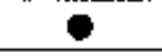 & $\$ 003.00$ & $04 / 16 / 07$ & 7,37 & 995.63 \\
\hline GW-345 & 53 & & - & 999.63 & $04 / 16 / 0 ?$ & 17,00 & 982.63 \\
\hline GW.347 & 53 & 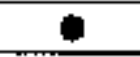 & & 1001.05 & $04 / 09 / 07$ & 17.00 & 984,05 \\
\hline GW-370 & BG & & e & 960.81 & $04 / 10 / 07$ & 15.04 & 945.77 \\
\hline $\mathrm{GW}-372$ & $\mathbf{B O}$ & & 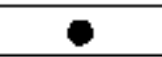 & 983.16 & $04 / 10 / 07$ & 38.59 & 964.57 \\
\hline GW-53] & LD & & 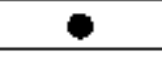 & 1004.61 & $04 / 16 / 07$ & 10.63 & 993.98 \\
\hline GW-537 & OLF & & 9 & 976.65 & $04 / 16 / 07$ & 5.38 & 971.27 \\
\hline GW-613 & 53 & & - & 1013.58 & $04 / 16 / 07$ & 8.54 & 1005.04 \\
\hline GW-621 & EXP-B & e & & 925.45 & $04 / 16 / 07$ & 6.60 & 918.85 \\
\hline GW-622 & BG & & 운 & 924.16 & $04 / 10 / 07$ & 10.14 & 914.02 \\
\hline GW-624 & BG & & 눈 & 922.15 & $04 / 10 / 07$ & 10.68 & 911.47 \\
\hline $\mathrm{GW}-630$ & $1 D$ & & e & 986.65 & $04 / 16 / 07$ & 8.73 & 977.92 \\
\hline GW-638 & OLF & & 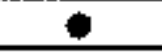 & 941.77 & $04 / 12 / 07$ & 5.72 & 936.05 \\
\hline GW-641 & BG & & 6 & 946.66 & $04 / 12 / 07$ & 17.85 & 928.81 \\
\hline GW-642 & $\mathrm{BG}$ & & 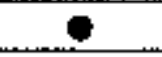 & 1014.95 & $04 / 10 / 07$ & 18.62 & 996.33 \\
\hline GW-645 & OLF & - & & 1006.40 & $04 / 16107$ & 64,20 & 942.20 \\
\hline$G W-648$ & RS & - & & 1029.20 & $04 / 16107$ & $6 ! .17$ & 968.03 \\
\hline GW-652 & BG & - & & 900.83 & $04 / 10 / 07$ & 9.94 & 890.89 \\
\hline GW-653 & BG & & 0 & 931.84 & $04 / 10 / 07$ & $22.7 \mathrm{~B}$ & 909.06 \\
\hline GW-654 & BG & & - & 940.79 & $04 / 10 / 07$ & 6.92 & 933.87 \\
\hline GW-795 & AGLLSF & & 0 & 926.18 & $04 / 12 / 07$ & 3.10 & 923.08 \\
\hline GW-835 & $\mathrm{S3}$ & & 0 & 1000.91 & $04 / 09 / 07$ & 14.60 & 986.31 \\
\hline GW-916 & EMWMF & & 0 & 1002,85 & $04 / 17 / 07$ & 4.24 & 998.61 \\
\hline GW-917 & EMWMF & & 1 & 997.10 & $04 / 12 / 07$ & 22.91 & 974.19 \\
\hline GW-g18 & EMVMF & & 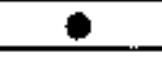 & 1067.96 & $04 / 12 / 07$ & 5.37 & 1062.59 \\
\hline GW-923 & EMWMF & & 0 & 1016.73 & $04 / 12 / 07$ & 31.69 & 985.04 \\
\hline GW-924 & EMWMF & & 0 & 968.99 & $04 / 17 / 07$ & 6.37 & 962.53 \\
\hline
\end{tabular}

Notes:

1 * = RCRA post-closure monitoring well sampled in calendar ycar 2007.

2 AGLLSF $=$ Above Grade Low-Level Storage Facility

BG = Bear Creek Burial Groutrds Waste Management Area

EMWMF = Enviroumental Managentent Waste Managentebt Facility

EXP-B = Exit Pathway (Maynardville Limestone) Picket B

LD = Lysimeter Demtonstration Site

OLF = Oil Landfarm Waste Manakement Area

RS $\quad$ E Rust Spoil Atra

SPI $=$ Spoil Area I

S3 3 S-3 Site

3 The measuring point is the surveyed elevation of a mark on either the tog of the innermost well casing or the top of dedicated sampling equipment, is leet above mean sea level.

4 The depth to water is in fect below the mcasuring point.

5 The groundwater elevation (measuring point depth to water) is in feet above mean sea level. 
Table 14. Depth-to-water measurements and groundwater elevations for selected wells in the Upper East Fork Poplar Creek Hydrogenologic Regime, April 2007

\begin{tabular}{|c|c|c|c|c|c|c|c|}
\hline \multirow{2}{*}{$\begin{array}{c}\text { Well } \\
\text { Number ' }\end{array}$} & \multirow{2}{*}{ Location ${ }^{2}$} & \multicolumn{2}{|c|}{ Hydrogenlogic Unit } & \multirow{2}{*}{$\begin{array}{l}\text { Measuring } \\
\text { Point }\end{array}$} & \multirow{2}{*}{$\begin{array}{c}\text { Date } \\
\text { Measured }\end{array}$} & \multirow{2}{*}{$\begin{array}{l}\text { Depth to } \\
\text { Water }{ }^{4}\end{array}$} & \multirow{2}{*}{$\begin{array}{c}\text { Groundwater } \\
\text { Elevation }^{5}\end{array}$} \\
\hline & & Aquifer & Aquitard & & & & \\
\hline $55-1 \mathrm{~A}$ & YL2 & & 0 & 986.91 & $04 / 09 / 07$ & 11.02 & 975.89 \\
\hline $55-3 \mathrm{~A}$ & YI2 & & 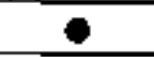 & 972.46 & $04 / 09 / 07$ & 11.75 & 960.71 \\
\hline $55-6 \mathrm{~A}$ & $\mathrm{Y} 12$ & & 0 & 989.29 & $04 / 09 / 07$ & 10.13 & 979.16 \\
\hline $56-1 \mathrm{~A}$ & $\mathrm{Y} 12$ & & 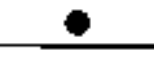 & 969.25 & $04 / 09 / 07$ & 7.57 & 961.68 \\
\hline $56-2 \mathrm{~A}$ & YI2 & & 0 & 963.53 & $04 / 09 / 07$ & 8.78 & 954.75 \\
\hline $56-8 \mathrm{~A}$ & $\mathrm{Y} 12$ & 0 & & 962.46 & $04 / 09 / 07$ & 20.19 & 942.27 \\
\hline $60-1 \mathrm{~A}$ & $\mathrm{Y} 12$ & 9 & & 929.66 & $04 / 12 / 07$ & 11.51 & 918.15 \\
\hline$G W-105$ & $\$ 3$ & & 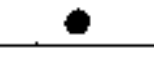 & 1018.20 & $04 / 10 / 07$ & 8.28 & 1009.92 \\
\hline GW-108* & 83 & & - & 999.00 & $04 / 10 / 07$ & 7.03 & 991.97 \\
\hline GW-115 & S3 & & 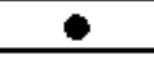 & 1055.01 & $04 / 10 / 07$ & 11.57 & 1043.44 \\
\hline GW-148 & NHP & - & & 907.76 & $04 / 11 / 07$ & 8.40 & 899.36 \\
\hline GW-152 & NHP & $\theta$ & & 921.18 & $04 / 11 / 07$ & 20.07 & 901.11 \\
\hline GW-154 & NHP & 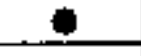 & & $9 ! 1.70$ & $04 / 1 \pm / 07$ & 9.68 & 902.02 \\
\hline GW-167 & EXP & 0 & & 931.95 & $04 / 11 / 07$. & 31.80 & 900.15 \\
\hline $\mathrm{GW}-169$ & EXP-UV & 0 & & 932.12 & $04 / 11 / 07$ & 31.25 & 900.87 \\
\hline GW-192 & B4 & & 0 & 1008.83 & $04 / 09 / 07$ & 5.91 & 1002.92 \\
\hline GW-193* & $\mathrm{T} 2331$ & 둔 & & 934.17 & $04 / 09 / 07$ & 9.02 & 925.15 \\
\hline GW-195 & B4 & & 0 & 1002.90 & $04 / 09 / 07$ & 6.57 & 996,33 \\
\hline GW.199 & GRIDI & & 둔 & 961.08 & $04 / 12 / 07$ & 17.12 & 943,96 \\
\hline GW-202 & RDS & & 9 & 968.02 & $04 / 12 / 07$ & 9.86 & 958.16 \\
\hline GW-204 & $\mathrm{T0134}$ & & 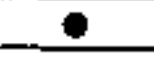 & 958.74 & $04 / 09 / 07$ & 8.69 & 950.05 \\
\hline GW-219 & UOV & 0 & & 935.63 & $04 / 10 / 07$ & 10.25 & 925.58 \\
\hline GW-253 & $\mathrm{s} 2$ & 0 & & 1004.24 & $04 / 10 / 07$ & 10.20 & 994.04 \\
\hline GW-255 & $\$ 2$ & 0 & & 1027.13 & $04 / 10 / 07$ & 28.18 & 998.95 \\
\hline GW-261 & SY & & - & 1049.99 & $04 / 10 / 07$ & 18.17 & 1031.82 \\
\hline GW-263 & SY & & ? & 1057.73 & $04 / 10 / 07$ & 29.97 & 1027.76 \\
\hline GW-334 & $W C$ & & 9 & 983.73 & $04 / 09 / 07$ & 11.40 & 972.33 \\
\hline GW-335 & $W C$ & & e & 981.88 & $04 / 09 / 07$ & 9.54 & 972.34 \\
\hline $\mathrm{GW}-349$ & $\underline{\mathbf{2}}$ & 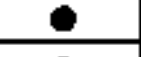 & & 993.50 & $04 / 09 / 07$ & 4.66 & 988.84 \\
\hline GW-380 & NHP & 0 & & 913.55 & $04 / 12 / 07$ & 10.22 & 903.33 \\
\hline GW-383 & $\mathrm{NHP}$ & & 돈 & 908,77 & $04 / 11 / 07$ & 9.30 & 899.47 \\
\hline $\mathrm{GW}-605^{*}$ & EXP-I & 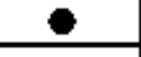 & & 919.06 & $04 / 12 / 07$ & 11,04 & 908.02 \\
\hline GW-606* & EXP-I & ㅇ & & 919.59 & $04 / 12 / 07$ & 13,45 & 906.14 \\
\hline GW-61? & EXP-E & ? & & 985.28 & $04 / 09 / 07$ & 13.67 & 971.61 \\
\hline GW-619 & FTF & - & & 1015.42 & $04 / 10 / 07$ & 25.20 & 990.22 \\
\hline GW-686 & CPT & 0 & & 963.76 & $04 / 09 / 07$ & 12.85 & 950.91 \\
\hline GW-691 & $\mathrm{CPT}$ & 1 & & 968.59 & $04 / 09 / 07$ & 12.35 & 956.24 \\
\hline
\end{tabular}


Table 14 (continued)

\begin{tabular}{|c|c|c|c|c|c|c|c|}
\hline \multirow{2}{*}{$\begin{array}{c}\text { Well } \\
\text { Number }\end{array}$} & \multirow{2}{*}{ Locstion $^{2}$} & \multicolumn{2}{|c|}{ Hydrogeolngic Unit } & \multirow{2}{*}{$\begin{array}{c}\text { Measnring } \\
\text { Point }^{3}\end{array}$} & \multirow{2}{*}{$\begin{array}{c}\text { Date } \\
\text { Measured }\end{array}$} & \multirow{2}{*}{$\begin{array}{c}\text { Depth to } \\
\text { Water } 4\end{array}$} & \multirow{2}{*}{$\begin{array}{l}\text { Groundwater } \\
\text { Elevation }\end{array}$} \\
\hline & & Aquiter & Aguitard & & & & \\
\hline GW-696 & B8110 & 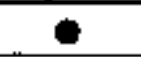 & & 969.78 & $04 / 11 / 07$ & 31.57 & 938.21 \\
\hline GW-733* & EXP-J & + & & 959,84 & $04 / 11 / 07$ & 59.36 & 900.48 \\
\hline GW-746 & GRIDK] & & $\theta$ & 906.88 & $04 / 11 / 07$ & 8.03 & 898.85 \\
\hline $\mathrm{GW}-752$ & GRIDJ3 & & 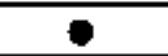 & 912.78 & $04 / 10 / 07$ & 4.13 & 908.65 \\
\hline GW-754 & GRIDJ2 & & - & 928.78 & $04 / 10 / 07$ & 10.89 & 917.89 \\
\hline GW-756 & GRIDI! & & 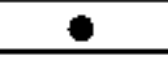 & 928.11 & $04 / 10 / 07$ & 6.00 & 922.11 \\
\hline GW-759 & GRLDGI & & 9 & 994.01 & $04 / 10 / 0 ?$ & 18.87 & 975.14 \\
\hline GW-761 & GRIDG2 & & - & 968.23 & $04 / 10 / 07$ & 10.75 & 957.48 \\
\hline GW-763 & GRIDJ3 & & e & 915.03 & $04 / 12 / 07$ & 8.96 & 906.07 \\
\hline GW-765 & GRIDEL & & - & 1008.54 & $04 / 10 / 07$ & 19.42 & 989.12 \\
\hline GW-767 & GRIDI2 & & - & 948.54 & $04 / 12 A 7$ & 10.46 & 938.08 \\
\hline GW-770 & GRIDG3 & & 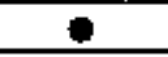 & 944.72 & $04 / 12 / 07$ & 10.60 & 934.12 \\
\hline GW-774 & GRIDH2 & & 9 & 963.16 & $04 / 12 / 07$ & 9.84 & 953.32 \\
\hline GW-776 & GRIDH3 & & 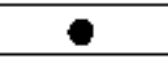 & 931.25 & $04 / 12 / 07$ & 13.08 & 918.17 \\
\hline GW-783 & GRIDE3 & & 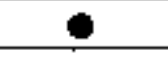 & 948.49 & $04 / 12 / 07$ & 10.28 & 938.21 \\
\hline GW- 792 & GRIDD2 & & 0 & 992.74 & $04 / 09 / 07$ & 25.39 & 967.35 \\
\hline GW-816 & EXP-SR & & 9 & 898.42 & $04 / 10 / 07$ & 12.14 & 886.28 \\
\hline GW-960 & GRID F2 & & 9 & 963.26 & $04 / 12107$ & 12.72 & 950.54 \\
\hline
\end{tabular}

Notes:

1 * = RCRA monitoring well sampled in calendar year 2007 .

Note that wells GW-605, GW-696, and GW-733 are bedrock interval monitoring wells.

$2 \quad$ B4 $=$ Beta-4 Security Pits

$\mathrm{B} 8110=$ Building $81-10$

B9201-2 = Buitding 9201-2

CPT $=$ Coal Pile Trench

EXP - Exit Pathway (Maynardville Limestone) monitoring well

-E, -I, or -J: Maynardville Limestone Picket

-UV: Offsite in Union Valley

-SR: Along Scartoro Road in the gap through Pine Ridge

FTF $=$ Fire Training Facility

GRID = Cornprehensive Groundwater Monitoring Plan Grid Location

NHP = New Hope Pond

RDS = Ravine Disposal Site

$\mathbf{S 2}=\mathbf{S - 2}$ Site

S3 = S.3 Site

$S Y=Y-12$ Plant Saivage Yard

T0134 $=$ Tank 0134-U

T2331 = Tank 2331-U

UOV - Uranium Oxide Vault

WC $=$ Waste Coolant Processing Area

Y12 = Y-12 Complex 


\section{Table 14 (continned)}

Notes: (continued)

3 The measuring point is the surveyed elevation of a mark on either the top of the innermost well casing or the top of dedicated sampling equipment, in feet above thean sea level,

4 The depth to water is in feet below the measuring potrl.

5 The groundwater elevation (measuring point depth to water) is in feet above mean sea level. 
Table 15. Depth-to-water measarements and groundwater elevations for selected wells in the Chestnut Ridge Hydrogealogic Regime, April 2007

\begin{tabular}{|c|c|c|c|c|c|}
\hline $\begin{array}{c}\text { Well } \\
\text { Number } 1\end{array}$ & Location ${ }^{2}$ & $\begin{array}{c}\text { Measuring } \\
\text { Point }\end{array}$ & $\begin{array}{c}\text { Date } \\
\text { Measured }\end{array}$ & $\begin{array}{l}\text { Depth to } \\
\text { Water }\end{array}$ & $\begin{array}{c}\text { Grutuadwater } \\
\text { Elevation } \\
\end{array}$ \\
\hline 1082 & ORSF & 837.28 & $04 / 09 / 07$ & 25.24 & 812.04 \\
\hline 1084 & ORSF & 965.40 & $04 / 09 / 07$ & 63.07 & 902.33 \\
\hline 1090 & INCS & 1104.48 & $04 / 10 / 07$ & 55,11 & 1049.37 \\
\hline GW-141 & LV & 1186.23 & $04 / 11 / 07$ & 96.24 & 1089.99 \\
\hline$G W-142$ & KHQ & 971.15 & $04 / 16 / 07$ & 136.72 & 834.43 \\
\hline GW-144* & $\mathrm{KHQ}$ & 913.54 & $04 / 16 / 07$ & 80.29 & 833.25 \\
\hline GW-145* & KHQ & 840.24 & $04 / 16 / 07$ & 5.90 & 834.34 \\
\hline GW-156* & CRSDB & 1049.28 & $04 / 1: 107$ & 143.05 & 906.23 \\
\hline GW-159* & CRSDB & 1051.38 & $04 / 11 / 07$ & 117.52 & 933.86 \\
\hline$G W-160$ & CRBAWP & 1093.09 & $04 / 11 / 07$ & 144.22 & 948.87 \\
\hline$G W-173$ & CRSPP & 111500 & $04 / 10 / 07$ & 149.89 & 965.11 \\
\hline GW-174 & CRSP & 1116.66 & $04 / 10 / 07$ & 116.76 & 999.90 \\
\hline GW-175 & CRSP & 1084.19 & $04 / 10 / 07$ & 122.11 & 962.08 \\
\hline GW-176 & CRSP & 1125.30 & $04 / 10 / 07$ & 116.23 & 1009.07 \\
\hline GW-177 & CRSP & 1158.20 & $04 / 1 / 07$ & 117.83 & 1040.37 \\
\hline GW-178 & CRSP & 1143.49 & $04 / 10 / 07$ & 91.33 & 1052.16 \\
\hline GW-179 & CRSP & $\$ 128.00$ & $04 / 10 / 07$ & 116.03 & 1011.97 \\
\hline$G W=180$ & CRSP & 1104.14 & $04 / 11 / 07$ & 116.68 & 987.46 \\
\hline GW-184 & RQ & 927.63 & $04 / 09 / 07$ & 110.21 & 817.42 \\
\hline GW-186 & $\mathrm{RQ}$ & 831.32 & $04 / 09 / 07$ & 14.73 & 816.59 \\
\hline GW-188 & $\mathrm{RQ}$ & 837.09 & 0410907 & 20.28 & 816.81 \\
\hline GW-203 & UNCS & 1105.45 & $04 / 10 / 07$ & 83.33 & 1022,12 \\
\hline GW-205 & UNCS & 1104.14 & $04 / 10 / 07$ & 80.00 & 1024.14 \\
\hline GW-217 & LIV & 1177.03 & $04 / 10 / 07$ & 112.18 & 1064.85 \\
\hline GW-221 & UNCS & 1106.16 & $04 / 10 / 07$ & 84.68 & 1021.48 \\
\hline GW-231* & $\mathrm{KHQ}$ & 849.67 & $04 / 16 / 07$ & 14.53 & 835.14 \\
\hline GW.241 & CRSDB & 982.84 & $04 / 16 / 07$ & 44.92 & 937.92 \\
\hline GW-292 & ECRWP & 1073.00 & $04 / 11 / 0 ?$ & 112.77 & 960.23 \\
\hline GW-298 & CRBAWP & 1049.01 & $04 / 11 / 07$ & 109.73 & 939.28 \\
\hline GW-299 & CRBAWP & 1053.86 & $04 / 11 / 07$ & 101.70 & 952.16 \\
\hline$G W-300$ & CRBAWP & 1073.12 & $04 / 11 / 07$ & 115.84 & 957.28 \\
\hline GW-301* & CRBAWP & 1086.55 & $04 / 11 / 07$ & 135.22 & 951.33 \\
\hline GW-302 & UNCS & 1141.84 & $04 / 11 / 07$ & 102.16 & 1039.68 \\
\hline GW-303 & CRSDB & 1007.16 & $04 / 11 / 07$ & 87.65 & 919.51 \\
\hline GW-304 & CRSDB & 1045,49 & $04 / 11 / 07$ & 117.19 & 928.30 \\
\hline GW-305 & LIV & 1183.72 & $04 / 16 / 07$ & 121.82 & 106190 \\
\hline GW.322 & CRSP & 1134.98 & $04 / 50 / 07$ & 159.20 & 975.78 \\
\hline GW.339 & UNCCS & 1124.83 & $04 / 10 / 07$ & 77.62 & 1047.21 \\
\hline
\end{tabular}


Table 15 (continued)

\begin{tabular}{|c|c|c|c|c|c|}
\hline $\begin{array}{c}\text { Well } \\
\text { Number' }\end{array}$ & Location ${ }^{2}$ & $\begin{array}{c}\text { Measuring } \\
\text { Point }^{3}\end{array}$ & $\begin{array}{c}\text { Date } \\
\text { Measured }\end{array}$ & $\begin{array}{l}\text { Depth 10 } \\
\text { Water }\end{array}$ & $\begin{array}{c}\text { Groundwater } \\
\text { Elevatlon }^{5}\end{array}$ \\
\hline GW-51] & CRSP & 1093.21 & $04 / 10107$ & 111.77 & 981.44 \\
\hline GW-S12 & FCAP & 1001.54 & $04 / 10 / 07$ & 26.05 & 975.49 \\
\hline $\mathrm{GW}-521 *$ & LIV & 1182.88 & $04 / 16 / 07$ & 82.33 & 1100.55 \\
\hline $\mathrm{GW}-522$ & LIV & 1175.48 & $04 / 1607$ & 103.34 & 1072.14 \\
\hline GW-539 & 높 & 1093.20 & $04 / 16107$ & 110.21 & 982.99 \\
\hline SWnS4l & CDLVI & 1058.40 & $04 / 16 / 07$ & 64.17 & 994.23 \\
\hline GW-542 & CDLVI & 1051.81 & $0416 / 07$ & 69.90 & 981.91 \\
\hline GW-543 & CDLVl & 1024.01 & $04 / 16 / 07$ & 60.64 & 963.37 \\
\hline GW-544 & CDLV & 1045.19 & $04 / 16 / 07$ & 54.66 & 990.53 \\
\hline GW-546 & CDLV1 & 1072.21 & $04 / 16 / 07$ & 86.09 & 986.12 \\
\hline$G W-557 *$ & LV & 1081.36 & $04 / 12 / 07$ & 125.21 & 956.15 \\
\hline GW-558 & SSCR & 981.42 & $04 / 12 / 07$ & 49.10 & 93232 \\
\hline GW-559 & SSCR & 1102.79 & $04 / 12 / 07$ & 139.50 & 963.29 \\
\hline GW-560 & CDLVII & 949.05 & $04 / 12 / 07$ & 51.80 & 897,25 \\
\hline GW-562* & CDLVII & 934.69 & $04 / 16 / 07$ & 12.71 & 921.98 \\
\hline GW-564 & CDLVII & 938.07 & $04 / 12 / 07$ & 11.38 & 926.69 \\
\hline GW-608 & CRSP & 1075.38 & $04 / 1 / 07$ & 138.47 & 936.91 \\
\hline GW-609 & CRSP & 1112.31 & $04 / 11 / 07$ & 167.68 & 944.63 \\
\hline GW-610 & CRSP & 1059.44 & $04 / 10 / 07$ & 97.72 & 961.72 \\
\hline GW-61! & CRSP & 1048.38 & $04 / 10 / 07$ & 103.65 & 944.73 \\
\hline$G W-612$ & CRSP & 1131.03 & $04 / 10 / 07$ & 123.42 & 1007.61 \\
\hline$G W-674$ & FCAP & 883.79 & $04 / 09 / 07$ & 8.18 & 875.61 \\
\hline$G W-676$ & FCAP & 846.50 & $04 / 09 / 07$ & 4.07 & 842.43 \\
\hline GW-677 & FCAP & 1030.40 & $04 / 10 / 07$ & 27.76 & 1002.64 \\
\hline GW-67s & FCAP & 1000.70 & $04 / 10 / 07$ & 21.39 & 979.31 \\
\hline GW-679 & FCAP & 1026.90 & $04 / 10 / 0 ?$ & 52.10 & 974.80 \\
\hline GW-680 & FCAP & 1001.50 & $04 / 12 / 07$ & 28.96 & 972.54 \\
\hline GW-709 & LII & 906.81 & $04 / 16 / 07$ & 20.35 & 886.46 \\
\hline GW-731* & CRSDB & 1049.38 & $04 / 11 / 07$ & 125.21 & 924.17 \\
\hline $\mathrm{GW}-732^{*}$ & CRSDB & 1064.29 & $04 / 11 / 07$ & 158.00 & 906.29 \\
\hline GW-743 & CRSP & 1100.36 & $04 / 11 / 07$ & 136.05 & 964.31 \\
\hline GW.757 & LII & 961.64 & $04 / 16 / 07$ & 79.47 & 882.17 \\
\hline GW-796 & LV & 1052.62 & $04 / 10 / 07$ & 84.38 & 968.24 \\
\hline GW-797 & LV & 1060.00 & $04 / 10 / 07$ & 77,20 & 982.80 \\
\hline GW-798 & CDLVII & 1006.00 & $04 / 12 / 07$ & 85.14 & 920.86 \\
\hline $\mathrm{GW}-799^{*}$ & LV & 981.29 & $04 / 12 / 07$ & 23.84 & 957.45 \\
\hline GW-801* & LV & 1097.16 & $04 / 12 / 07$ & 114.95 & 982,21 \\
\hline GW-827 & CDLVI & 1051.60 & $04 / 16 / 07$ & 42.58 & 1009.02 \\
\hline$G W-831 *$ & FCAP & 1091.29 & $04 / 10 / 07$ & 130,60 & 960.69 \\
\hline
\end{tabular}




\section{Table 15 (continned)}

Notes:

1 * = RCRA monitoring well sampled in calendar year 2007 .

2 CDLVI = Construction:Demolition Landfill VI

CDLVI! = Constructiond Demolition Landfill VII

CRBAWP = Chestmut Ridge Borrow Area Waste Pile

CRSDB $=$ Chestout Ridge Sediment Disposal Basin

CRSP = Chestmut Ridge Security Pits

ECRWP = East Chestnut Ridge Waste Pile

FCAP $=$ Filled Coal Ash Pond

$\mathrm{KHQ}=$ Kerr Hollow Quarry

LU = Industrial Landfil Il

LTV = Industrial Landfill IV

$\mathrm{LV}=$ Industrial Landfill $\mathrm{V}$

ORSF = Oak Ridge Sludge Fam

$R Q=$ Rogers Quarty

SSCR = South Side Chestnut Ridge

UNCS \& United Nuctear Corporation Site

3 The measuring point is the surveyed elevation of a mark on either the top of the innermost well casing or the top of dedicated sampling equipment, in feet above mean sea level.

4 The depth to water is in feet below the nyeasuring point.

5 The groundwater elevation (measuring point - depth to water) is in feet dbove mean sea level. 
Table 16. CY 2007 leachate sampling results for the East Chestnut Ridge Waste Pile

\begin{tabular}{|c|c|c|c|c|c|}
\hline \multirow{2}{*}{ Analyte (units) } & \multirow{2}{*}{$\begin{array}{c}\text { Target } \\
\text { Compound }\end{array}$} & \multicolumn{2}{|c|}{ March 12,2007} & \multicolumn{2}{|c|}{ August 21,2007} \\
\hline & & Result ${ }^{2}$ & Det. Limit & Result ${ }^{2}$ & Det. Limit \\
\hline \multicolumn{6}{|l|}{ Inorganics (mg/) } \\
\hline A luminum & & $0.2 \mathrm{U}$ & 0.2 & $0.2 \mathrm{U}$ & 0.2 \\
\hline Antimony & $\mathbf{Y}$ & $0.004 \mathrm{U}$ & 0.004 & $0.003 \mathrm{U}$ & 0.003 \\
\hline Arsenic & $\mathrm{Y}$ & $0.004 \mathrm{U}$ & 0.004 & $0.004 \mathrm{U}$ & 0.004 \\
\hline Barium & $\mathrm{Y}$ & 0.0406 & 0.004 & 0.0437 & 0.004 \\
\hline Beryllium & & $0.004 \mathrm{U}$ & 0.004 & $0.004 \mathrm{U}$ & 0.004 \\
\hline Boron & $Y$ & NA & & 0.332 & $0.0 \mathrm{I}$ \\
\hline Cadmium & $\mathrm{Y}$ & $0.004 \mathrm{U}$ & 0.004 & $0.00012 \mathrm{U}$ & 0.00012 \\
\hline Chloride & $Y$ & 41 & 2.5 & 42.2 & 2.5 \\
\hline Chromiurn & $Y$ & $0.004 \mathrm{U}$ & 0.004 & $0.004 \mathrm{U}$ & 0,004 \\
\hline Cobalt: & $Y$ & $0.004 \mathrm{U}$ & 0.004 & $0.004 \mathrm{U}$ & 0.004 \\
\hline Copper & $Y$ & $0.004 \mathrm{U}$ & 0.004 & $0.004 \mathrm{U}$ & 0.004 \\
\hline Iron & $Y$ & 0.418 & 0.2 & $0.2 \mathrm{~J}$ & 0.2 \\
\hline Lead & $Y$ & $0.004 \mathrm{U}$ & 0.004 & $0.002 \mathrm{~V}$ & 0.002 \\
\hline Lithiurn & $Y$ & 0.136 & 0.01 & 0.151 & 0.01 \\
\hline Manganese & $\mathbf{Y}$ & 0.0196 & 0.005 & $0.005 \mathrm{U}$ & 0.005 \\
\hline Mercury & $Y$ & $0.0002 \mathrm{U}$ & 0.0002 & $0.0002 \mathrm{U}$ & 0.0002 \\
\hline Nickel & $Y$ & $0.01 \mathrm{U}$ & 0.01 & $0.01 \mathrm{U}$ & 0.01 \\
\hline Nitrate (as N) & $Y$ & 0.34 & 0.02 & 0.75 & 0.02 \\
\hline Potassinm & & $\mathrm{NA}_{\mathrm{A}}$ & & 7,88 & 0.025 \\
\hline Selenium & $Y$ & $0.005 \mathrm{U}$ & 0.005 & $0.0025 \mathrm{G}$ & 0.0025 \\
\hline Silver & & $0.005 \mathrm{U}$ & 0.005 & $0.0015 \mathrm{U}$ & 0.0015 \\
\hline Sodium & & NA & & $2 \theta .2$ & 0,01 \\
\hline Strontium & & 0.366 & 0.005 & 0.41 & 0.005 \\
\hline Sulfate & $\mathrm{Y}$ & 6 & 0.25 & 6.4 & 0.25 \\
\hline Thallium & $\mathrm{Y}$ & $0.002 \mathrm{U}$ & 0.002 & $0.002 \mathrm{U}$ & 0.002 \\
\hline Uranium & $\mathbf{Y}$ & 0.0146 & 0.00104 & 0.0115 & 0.00105 \\
\hline Vanadium & & $0.01 \mathrm{U}$ & 0.01 & $0.01 \mathrm{U}$ & 0.01 \\
\hline Zinc & $\mathbf{Y}$ & $0.2 \mathrm{U}$ & 0.2 & $0.2 \mathrm{U}$ & 0.2 \\
\hline \multicolumn{6}{|l|}{ Organjes $(\mu \mathrm{g} / \mathrm{L})$} \\
\hline 1,1,1-Trichloroethane & $\mathrm{Y}$ & 58 & 5 & 24 & 5 \\
\hline 1,1,2,2-Tetrachlotoethane & & $5 \mathrm{U}$ & 5 & $5 \mathrm{U}$ & 5 \\
\hline 1,1,2-Trichloroethane & & $5 \mathrm{U}$ & 5 & $5 \mathrm{U}$ & 5 \\
\hline 1,1-Dichlotoethane & $\mathbf{Y}$ & 360 & 10 & 130 & 5 \\
\hline 1,1-Dichloroethene & $\mathrm{Y}$ & $\mathbf{s}$ & 5 & $2 \mathbf{J}$ & 5 \\
\hline I,2-Dichloroethane & $\mathrm{Y}$ & $5 \mathrm{U}$ & 5 & $1 \mathrm{~J}$ & 5 \\
\hline 1,2-Dichloropropane: & & $5 \mathrm{U}$ & 5 & $5 \mathrm{U}$ & 5 \\
\hline 2-Butanone & & [4] U & 10 & $10 \mathrm{U}$ & 10 \\
\hline 2-Hexanone & & $10 \mathrm{U}$ & 10 & $10 \mathrm{U}$ & 10 \\
\hline 4-Methyl-2-pentanone & & $10 \mathrm{U}$ & 10 & $10 \mathrm{U}$ & 10 \\
\hline Acetone] & & [2] U & 10 & $10 \mathrm{U}$ & 10 \\
\hline Benzene & $\mathrm{Y}$ & $5 \mathrm{U}$ & 5 & $5 \mathrm{U}$ & 5 \\
\hline Bromodichloromethane & & $5 \mathrm{U}$ & 5 & 50 & 5 \\
\hline Bromoform & & $5 \mathrm{U}$ & 5 & 50 & 5 \\
\hline Bromongthane & & $10 \mathrm{U}$ & 10 & 100 & 10 \\
\hline
\end{tabular}


Table 16 (continued)

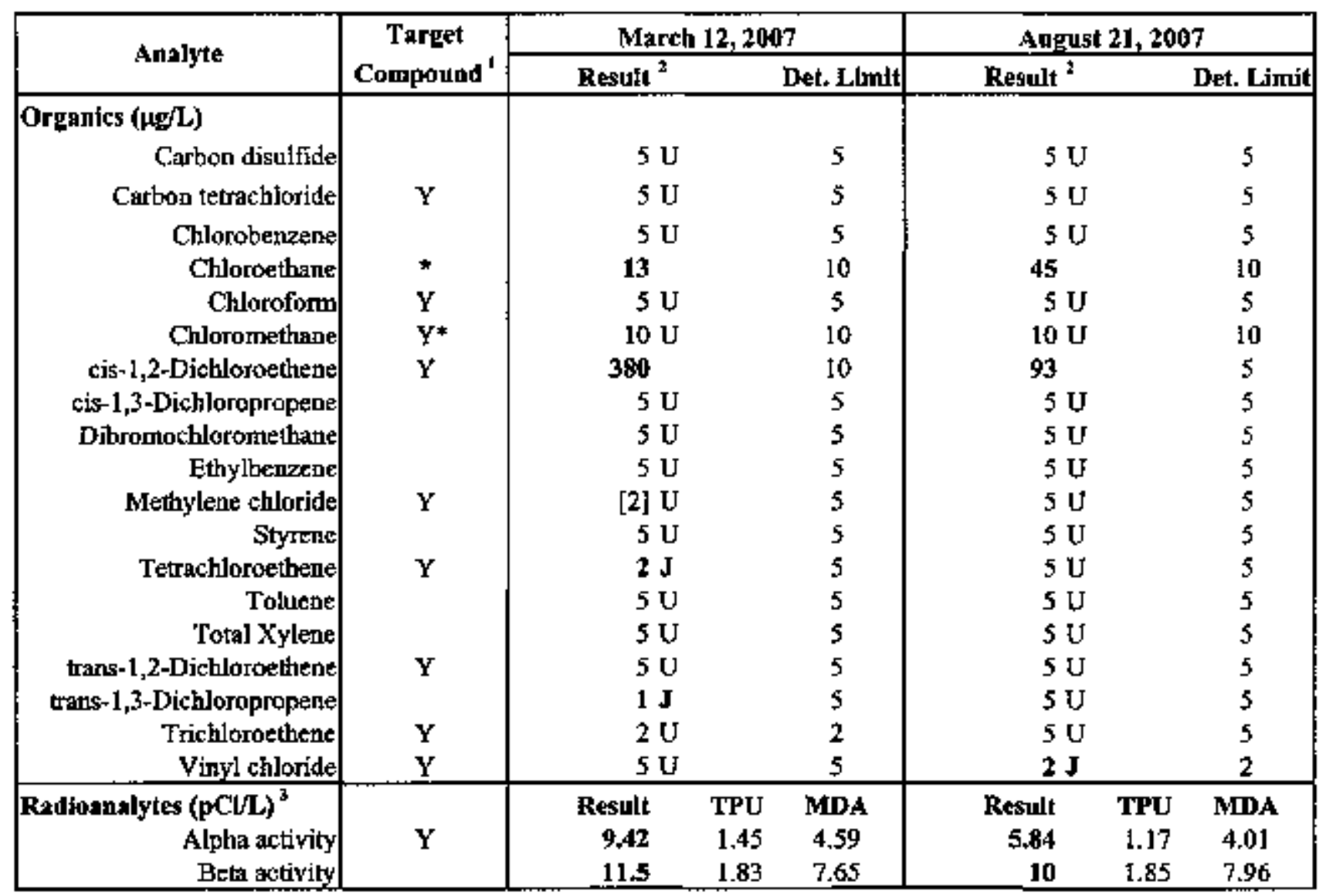

Notes:

$1 \quad \mathrm{Y}=$ RCRA Groundwater Target List Compound

* = Suspected typographical errot; chloroethane inconretly listed as chloromethane

2 Bold type $=$ Detected result

$$
\begin{aligned}
\text { NA } & =\text { Not analyzed } \\
{[] } & =\text { False-positive result (not detected) } \\
\text { J } & =\text { Estimated value } \\
\text { U } & =\text { Not detected }
\end{aligned}
$$

$3 \quad$ MDA $\approx$ Minimum detectable activity

TPU $=$ Total propagated uncertainty 
APPENDIX C

CY 2007 RCRA POST-CLOSURE GROUNDWATER MONITORING DATA FOR THE BEAR CREEK HYDROGEOLOGIC REGIME 


\section{EXPLANATION}

\section{SAMPLE TYPE;}

Dup = field duplicate sample (Table 4 only)

\section{UNITS:}

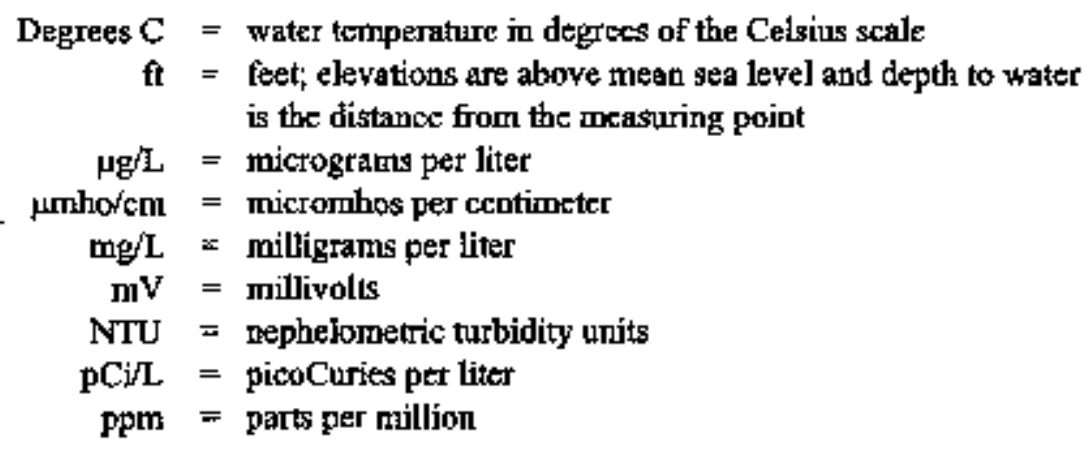

\section{DATA QUALIFIIERS:}
B = also detected in the associnted method blark (organics)
D = analysis performed at a secondary dilution to achieve an optimum matrix
$\mathrm{J}=$ positively identified, estimated value below the quantitation level (organics)
$\mathrm{U}=$ not detected at or above the project quantitation level

NOTES:

\footnotetext{
. = not analyzed

Error = total propagated uncertainty (two standard deviations) (radiochemistry)

MDA = minimum defectable activity (radiochemistry)
} 
This page intentionally left blank. 


\section{Appendix C: CY 2007 RCRA Post-Clasure Groundwater Monitoríag Data for the Bear Creak Hydrageoligic Regime Teumessee Permit Number: TNHW-116}

T2ble 1. S-3 Site Point-of-Compliance

\begin{tabular}{|c|c|c|c|c|c|c|}
\hline \multirow{2}{*}{$\begin{array}{rr}\text { Well } \\
\text { Drte Sampled }\end{array}$} & \multicolumn{6}{|c|}{ GW-276 } \\
\hline & \multicolumn{3}{|c|}{$01 / 03 / 07$} & \multicolumn{3}{|c|}{$07 / 0907$} \\
\hline Fintid Mersurements & Result & & & Resurft & & \\
\hline Time Sanplext & $9: 35$ & & & 9:05 & & \\
\hline Measuring Pount Elev. (ft) & 1001.57 & & & 1001.57 & & \\
\hline Depth to Water (ft) & 5.87 & & & 7.94 & & \\
\hline Oroundwater Elevation ( $\mathrm{f}$ ) & 995.70 & & & 993.63 & & \\
\hline Conductivity ( $\mu$ mhotem) & 396 & & & 522 & & \\
\hline Dissolved Oxycen (ppm) & 7.65 & & & i.2 & & \\
\hline OxidationReduction (mV) & 255 & & & 254 & & \\
\hline Temperature (degrees C) & 12 & & & 23.8 & & \\
\hline Turtidity (NTU) & I & & & 8 & & \\
\hline $\mathrm{pH}$ & 4.94 & & & 5.81 & & \\
\hline Inorganies (mplL) & Result & & Det_Limit & Result & & Det. Limitt \\
\hline Barium & 0.0794 & & 0.005 & 0.1 & & 0.005 \\
\hline Cadmium & 0.0099 & & 0.001 & 0.0074 & & 0.00012 \\
\hline Chromium & 0.005 & & 0.005 & 0.005 & & 0.005 \\
\hline Mercury & 0.00024 & & 0.0002 & 0.0002 & & 0.0002 \\
\hline Nickel| & 0.125 & & 0.01 & 0.102 & & 0.01 \\
\hline Nutrate (as $\mathrm{M}$ ) & 19.4 & & 1 & 29.6 & & 1 \\
\hline Utanium] & 0.45 & & 0.00009 & 0.21 & & 0.00003 \\
\hline 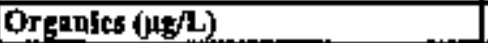 & Fesult & & Det. Limit & $\overline{\text { Resplt }}$ & & Det. Limit \\
\hline Acetone & 3 & BJ & 10 & 10 & & 10 \\
\hline Chloroform & 5 & & 5 & & & 5 \\
\hline cis-1,2-Dichlorocthetre & 5 & & 5 & & & 5 \\
\hline Methylere chloride & 3 & BJ & 5 & & & 2 \\
\hline Tetrachlorothene] & 5 & & 5 & 4 & & 2 \\
\hline Trichloroethene & 5 & & 5 & & & 2 \\
\hline Radloanalytes (pCUL) & Result & $\overline{\mathbf{T P}} \dot{\mathbf{P}}$ & MDA & Resule & TPU & $\overline{\mathbf{M D A}}$ \\
\hline Alpha activity & 520 & 20.6 & 2.65 & 109 & 19.1 & 2.26 \\
\hline Beta activty & 151 & 24.9 & 5.42 & 218 & 35.5 & 4.79 \\
\hline Americium-241 & 0.0681 & 0.0886 & 0.123 & 0.0427 & 0.0388 & 0.0232 \\
\hline Neplutium-237 & 6.77 & 2.72 & 0.108 & 4.6 & 1.84 & 0.0663 \\
\hline Total Radium & 1.24 & 0.593 & 0.408 & 0.177 & 0.101 & 0.132 \\
\hline Strontium-90| & 1.4 & 0.659 & 0.913 & 2.41 & 1.31 & 2.38 \\
\hline Texbinetium-99 & 233 & 38.5 & 6.47 & 282 & 46.1 & 6.09 \\
\hline Urandım-234 & 57.2 & II & 0.339 & 49.2 & 9.15 & 0.544 \\
\hline Uranium-235 & 3.2 & 1.16 & 0.216 & 3.96 & 1.36 & 0.488 \\
\hline Uranium-238 & 118 & 21.9 & 0.293 & 107 & IB.7 & 0.489 \\
\hline
\end{tabular}




\section{Appendix C: CY 2007 RCRA Post-Closurc Groundwater Monitoring Data for the Bear Creek Fydrogenlogic Regime \\ Tennessex Permit Number: TNHW-116}

Table 2. OAl Landfarm Point-of-Compliance

\begin{tabular}{|c|c|c|c|c|c|}
\hline \multirow{2}{*}{$\begin{array}{r}\text { Well } \\
\text { Date Sampled } \\
\end{array}$} & \multicolumn{5}{|c|}{ GW-008 } \\
\hline & \multicolumn{2}{|l|}{$01 / 02107$} & \multicolumn{3}{|c|}{$07 / 02 / 07$} \\
\hline Field Measurements & Result & & Resutt & & \\
\hline Time Sampled & $13: 23$ & & I3:16 & & \\
\hline Measurigg Point Eley. (ft) & 965.39 & & 965.39 & & \\
\hline Depth to Water (ft) & 14.42 & & 16.56 & & \\
\hline Groundwater Elevation (ft) & 950.97 & & 948.83 & & \\
\hline Conductivity (jmho/ $\mathrm{cm})$ & 222 & & 135 & & \\
\hline Dissolved Oxygen (ppm) & 1.21 & & I.21 & & \\
\hline Oxidation/Reduction (mv)] & 118 & & 128 & & \\
\hline Tetmperatute (dcgrees C) & 17 & & 18 & & \\
\hline Tubidity (NTU) & 1 & & 2 & & \\
\hline $\mathbf{p H}$ & 5.77 & & 6.02 & & \\
\hline Inor zanics (m)/2) & Respilt & Det. Llmilt & Result & & Det. Limit \\
\hline Barium & 0.093 & 0.005 & 0.121 & & 0.005 \\
\hline Cardmium & $0.001 \mathrm{U}$ & 0.001 & $0.00012 \mathrm{U}$ & & 0.00012 \\
\hline Mercury & $0.0002 \mathrm{U}$ & 0.0002 & $0.0002 \mathrm{U}$ & & 0.0002 \\
\hline Branium & $0.000054 \mathrm{~B}$ & 0.000000 & $0,000046 \mathrm{~B}$ & & 0.0000046 \\
\hline Orgenies ( $\mu \mathrm{g} / \mathrm{L})$ & Result & Det. Limlt & Resilt & & Det LImit \\
\hline I,I-Dichlotoethene & 6 & 5 & 4 & & 3 \\
\hline cis-I,2-Djchloroethene & 21 & 5 & 23 & & 5 \\
\hline Tetrachlosocthene & 40 & 5 & 73 & & 2 \\
\hline Trichloroethene & 9 & 5 & 11 & & 2 \\
\hline RAdlasenlytes (pCllL) & Result & MDA & Result & TPU & MDA \\
\hline Alpha activity & -0.510 .578 & 2.07 & $\overline{1.93}$ & 1.35 & 2.05 \\
\hline Beta activity & 2.22 & 3.32 & 3.54 & 1.92 & 3.61 \\
\hline
\end{tabular}




\section{Appendix C: CY 2007 RCRA Post-Closure Groundwater Monitoring Data tor the Besar Creek Hydrageologic Regime \\ Tennessee Permit Number: TNHW-116}

Table 3. BC Burial Gronnds/Walk-In Pits Point-of-Compliance

\begin{tabular}{|c|c|c|c|c|c|c|}
\hline \multirow{2}{*}{\begin{tabular}{rr|} 
Well \\
Date Sompled \\
\end{tabular}} & \multicolumn{6}{|c|}{ GW4.046 } \\
\hline & \multicolumn{3}{|c|}{$01,103 / 07$} & \multicolumn{3}{|c|}{$0702 / 07$} \\
\hline Field Mensutenents & \multicolumn{3}{|l|}{ Result } & \multicolumn{2}{|c|}{ Rexnalt } & \\
\hline Time Sampled & \multicolumn{2}{|l|}{$9: 35$} & & \multicolumn{2}{|c|}{$13: 50$} & \\
\hline Measuring Point Elev, (ft) & \multicolumn{2}{|l|}{921.17} & & \multicolumn{2}{|c|}{921.17} & \\
\hline Depth to Water (ft) & \multicolumn{2}{|l|}{4.02} & & \multicolumn{2}{|c|}{5.52} & \\
\hline Groundwater Elevalion (f) & \multicolumn{2}{|l|}{917.15} & & \multicolumn{2}{|c|}{915.65} & \\
\hline Conductivity ( $\mu$ mhorcm) & \multicolumn{2}{|l|}{212} & & \multicolumn{2}{|c|}{110} & \\
\hline Dissolved Dxygen (ppm) & \multicolumn{2}{|l|}{0.42} & & \multicolumn{2}{|c|}{0.24} & \\
\hline Oxidation/Rectuction (mV) & \multicolumn{2}{|l|}{202} & & \multicolumn{2}{|c|}{180} & \\
\hline Teniperahure (degres C) & \multicolumn{2}{|l|}{14.5} & & \multicolumn{2}{|c|}{ I8.] } & \\
\hline Turbidity (NTW) & \multicolumn{2}{|l|}{3} & & \multicolumn{2}{|c|}{6} & \\
\hline $\mathrm{pH}$ & \multicolumn{2}{|l|}{5.56} & & \multicolumn{2}{|c|}{5.37} & \\
\hline Inorynics (mgit) & \multicolumn{2}{|l|}{ Pesalt } & Det. Limit & Resul & & Det Limit \\
\hline Uranium & \multicolumn{2}{|c|}{$0.000065 \mathrm{~B}$} & 0.000009 & 0.000047 & & 0.0000046 \\
\hline Drganies ( $\mu$ fL) & \multicolumn{2}{|l|}{ Reszilt } & Det. Limit & \multicolumn{2}{|c|}{ Result } & Det. Limit \\
\hline I,1,1-Trichloroethane & 33 & & 5 & 19 & & 5 \\
\hline I,I-Dichloroethane & 95 & & 5 & 70 & & 5 \\
\hline I,I-Dichloroethene & $\mathbf{4 6}$ & & 5 & 27 & & 3 \\
\hline Berszenc & 9 & & 5 & 9 & & 2 \\
\hline cls-1,2-Dichlorothene & 2,500 & & 120 & 1,700 & & 250 \\
\hline Tetrachloroethene & 370 & & 120 & 420 & & \pm 00 \\
\hline Trithlorocthene & 730 & & 120 & 620 & & 100 \\
\hline Vinyl Chloride & 240 & & 50 & 170 & & 50 \\
\hline Radloanalytes (pCL/L) & Result & TPU & MDA & Resilt & TPU & MDA \\
\hline Alpha activity & 0.873 & 1.01 & 2.02 & 1.13 & $\$ .07$ & 1.85 \\
\hline Beth ectivity & 2.19 & 1.9 & 3.95 & 2.16 & 1.78 & 3.65 \\
\hline Technetium-99 & -3.69 & 3.44 & 6.15 & 0.518 & 4.07 & 6.95 \\
\hline Uranitum-234 & -0.0269 & 0.156 & 0.283 & 0.408 & 0.364 & 0.476 \\
\hline UTanium-235 & 0.0527 & 0.184 & 0.143 & 0.231 & 0.273 & 0.41 \\
\hline Uranjustm-238 & 0.0787 & 0.157 & 0.223 & 0.153 & 0.238 & 0.445 \\
\hline
\end{tabular}




\section{Appendir C: CY 2007 RCRA Post-Closure Grouddwater Monitoring Data far the Bear Creek Hydrogetologic Regime \\ Tennessee Permit Number: TNHW-116}

Table 4. Plume bondery montitoring locntions

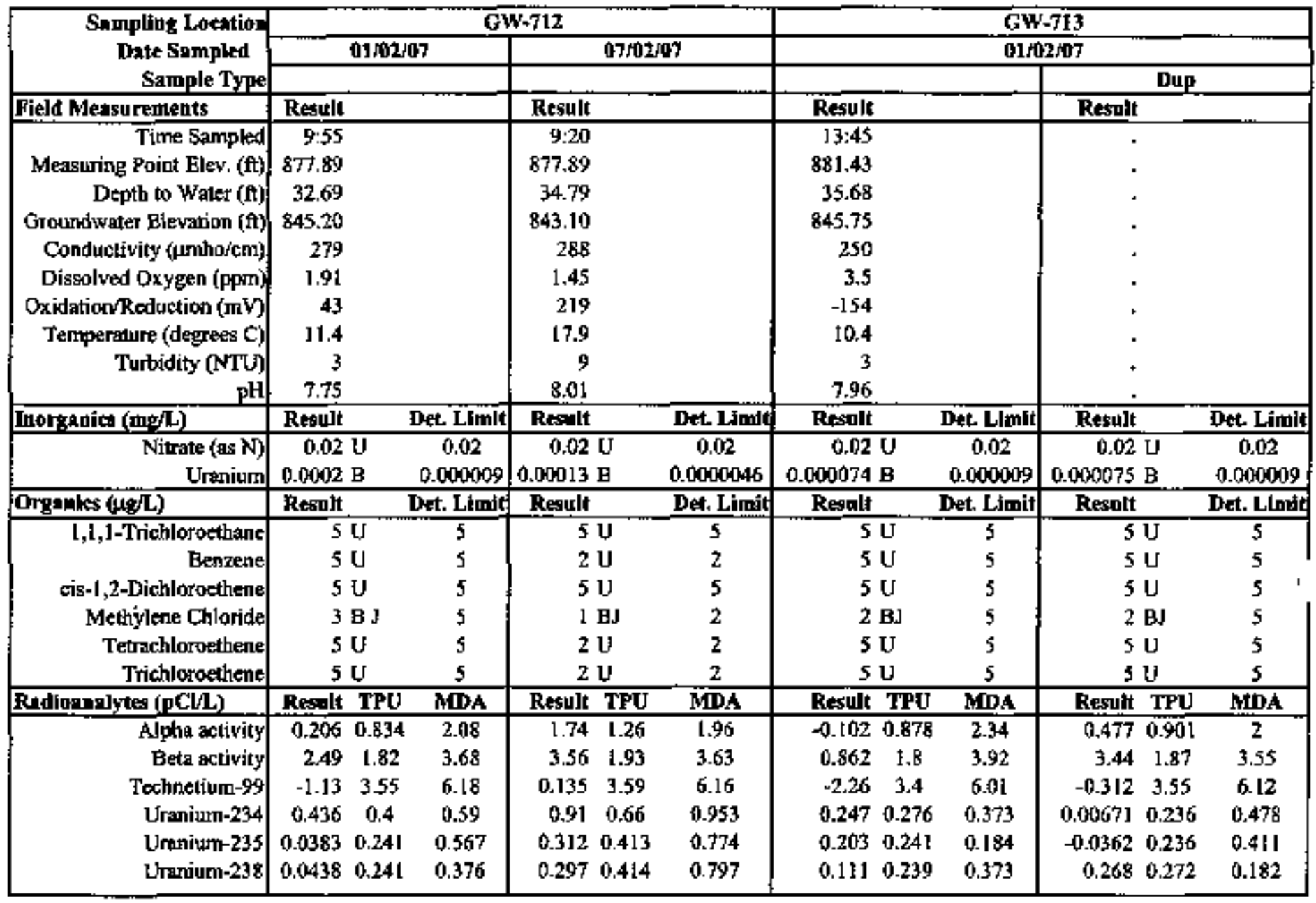




\section{Appendix C; CX 2007 RCRA Pust-Closure Groundwater Monitoring Data \\ For the Bear Creek Hydrogeotogic Repime \\ Tennessee Permit Number: TNHW-116}

Tahle 4. (continued)

\begin{tabular}{|c|c|c|c|c|c|c|c|c|c|c|}
\hline \multirow{3}{*}{$\begin{array}{c}\text { Sampling Loratleu } \\
\text { Date Sampled } \\
\text { Sumple Type }\end{array}$} & \multirow{2}{*}{\multicolumn{4}{|c|}{$\begin{array}{l}\text { GW-713 } \\
07 / 03 / 07 \\
\end{array}$}} & \multicolumn{6}{|c|}{ GW-714 } \\
\hline & & & & & \multicolumn{3}{|c|}{01,02407} & \multicolumn{3}{|c|}{$07 / 02107$} \\
\hline & & & \multicolumn{2}{|l|}{ Dup } & & & & & & \\
\hline Field Measuremeats & \multicolumn{2}{|l|}{ Result } & \multicolumn{2}{|l|}{ Result } & \multicolumn{3}{|l|}{ Result } & \multicolumn{3}{|l|}{ Resnlt } \\
\hline Tirne Sarnpled & \multicolumn{2}{|l|}{$9: 25$} & \multicolumn{2}{|l|}{ - } & \multicolumn{3}{|c|}{$9: 40$} & \multicolumn{3}{|c|}{$9: 20$} \\
\hline Measuring Point Elev, (ft) & \multicolumn{2}{|l|}{881.43} & \multicolumn{2}{|l|}{. } & \multicolumn{3}{|l|}{874.92} & \multicolumn{3}{|l|}{875.88} \\
\hline Depth to Water (tt) & \multicolumn{2}{|l|}{37.8} & \multicolumn{2}{|l|}{. } & \multicolumn{3}{|c|}{28.98} & \multicolumn{3}{|c|}{31,08} \\
\hline Groundwater Elevation (ft) & \multirow{2}{*}{\multicolumn{2}{|c|}{843.63}} & \multicolumn{2}{|l|}{ - } & \multicolumn{3}{|l|}{845.94} & \multicolumn{3}{|l|}{844.80} \\
\hline Conductiviry (umho/cm) & & & \multicolumn{2}{|l|}{ - } & 578 & & & 546 & & \\
\hline Dissolved Oxygen (ppm) & \multicolumn{2}{|l|}{2.22} & . & & 0.95 & & & $1.3 \mathrm{I}$ & & \\
\hline Oxidation/Reduction (mV) & -169 & & . & & 227 & & & 90 & & \\
\hline Temperature (degrees C) & 19.2 & & . & & 9.2 & & & 19.2 & & \\
\hline Turtidity (NTU) & 8 & & . & & 3 & & & 14 & & \\
\hline $\mathrm{pH}$ & 8.04 & & & & 7.66 & & & 7.57 & & \\
\hline Inorganks (mes) & Resinlt & Det. Limit & Resalt & Det. Llmite & Result & & Det. Ltmut & Result & & Det. Limitit \\
\hline Nitrate (as N) & $0.02 \mathrm{U}$ & 0.02 & $0.02 \mathrm{U}$ & 0.02 & 0.36 & & 0,02 & 0.24 & & 0.02 \\
\hline Uranium & $0.00002 \mathrm{~B}$ & 0.0000059 & $0,000014 \mathrm{~B}$ & 0.0000059 & 0.0016 & & 0.000009 & 0,0016 & & 0.0000046 \\
\hline Ortanks $(\mu \mathrm{g} / \mathrm{L})$ & Result & Det. Limit & Result & Det. Linit & Result & & Det_Limit & Kesult & & Det. Limit \\
\hline 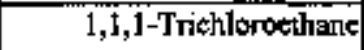 & $5 \mathrm{~J}$ & 5 & $5 \mathrm{U}$ & 5 & & $\overline{\mathrm{U}}$ & 5 & & $\overline{\mathrm{U}}$ & 5 \\
\hline Benzene & $2 U$ & 2 & $2 \mathrm{U}$ & 2 & & $\mathrm{u}$ & 5 & & $\mathrm{u}$ & 2 \\
\hline ci5-1,2-Dichlorothenc & $5 \mathrm{U}$ & 5 & $5 \mathrm{U}$ & 5 & & $\mathbf{U}$ & 5 & & $\mathrm{U}$ & 5 \\
\hline Methylene Chloride & $2 \mathrm{BJ}$ & 2 & $1 \mathrm{BJ}$ & 2 & & QJ & $s$ & & BJ & 2 \\
\hline Tetrachlorsothene & $2 \mathrm{U}$ & 2 & $2 \mathrm{U}$ & 2 & & $v$ & 5 & & $\mathrm{U}$ & 2 \\
\hline Trichloroethẹte & $2 \mathrm{U}$ & 2 & $2 \mathrm{U}$ & 2 & & $\mathrm{u}$ & 5 & & $\mathbf{U}$ & 2 \\
\hline Radiosnalytes (pCuL) & Result TPU & MDA & Resplt TPU & MDA & Regalt & TPU & MDA & Resclt & TPU & MDA \\
\hline Alpha activity & $0.465 \quad 0.694$ & 1.45 & $1.11 \quad 1.1$ & 2.08 & 1.53 & 1.26 & 2.05 & 1.8 & 1.28 & 1.95 \\
\hline Beta antivity & $3.72 \quad 1.6$ & 2.87 & $2.77 \quad 1.83$ & 3.6 & 3.71 & 2.05 & 3.9 & 3.27 & 1.98 & 3.83 \\
\hline Technetium-99 & $-1.72 \quad 3.56$ & 6.25 & $-0.213 \quad 3.47$ & 5.98 & 0.224 & 3.67 & 6.28 & -0.876 & 3.78 & 6.58 \\
\hline UTemiutrn-234 & $0.814 \quad 0.511$ & 0.435 & $\begin{array}{lll}0.476 & 0.412\end{array}$ & 0.504 & 0.888 & 0.53 & 0.482 & 1.79 & 0.96 & 0.732 \\
\hline Uranium-235 & $\begin{array}{lll}0.129 & 0.251\end{array}$ & 0.333 & $0.427 \quad 0.38$ & 0.417 & 0.179 & 0.24 & 0.373 & 0.271 & 0.39 & 0.674 \\
\hline Uranium-238 & $0.142 \quad 0.251$ & 0.193 & $0.441 \quad 0.379$ & 0.355 & 0.666 & 0.443 & 0.317 & 0.541 & 0.56 & 0.83 \\
\hline
\end{tabular}


Appendix C: CY 2007 RCRA Post-Closure Groundwater Monitoring Datn for the Bear Creek Hydrogeologic Regime

Tennessee Permit Number: TNHW-t 16

Table 4. (continued)

\begin{tabular}{|c|c|c|c|c|c|c|}
\hline \multirow{2}{*}{\begin{tabular}{|c|} 
Sampling Locition \\
Date Sampled \\
Sample Type
\end{tabular}} & \multicolumn{6}{|c|}{ SS-6 } \\
\hline & \multicolumn{3}{|c|}{0310307} & \multicolumn{3}{|c|}{ o7rozun } \\
\hline Fleld Mensurements & \multicolumn{3}{|l|}{ Result } & \multicolumn{3}{|l|}{ Result } \\
\hline Time Sermpled & \multicolumn{3}{|l|}{$13: 25$} & \multicolumn{3}{|l|}{$8: 18$} \\
\hline Measuring Point Elev (in) & \multicolumn{3}{|l|}{+} & \multicolumn{3}{|l|}{, } \\
\hline Depth to Wate (ft) & \multicolumn{3}{|l|}{. } & \multicolumn{3}{|l|}{ - } \\
\hline Groundwater Elevation (ft) & \multicolumn{3}{|l|}{$\bullet$} & \multicolumn{3}{|l|}{. } \\
\hline Conductivity ( $\mu$ mhoicm) & \multicolumn{3}{|l|}{285} & \multicolumn{3}{|l|}{432} \\
\hline Dissolved Oxygen (ppm) & \multicolumn{3}{|l|}{10.7} & \multicolumn{3}{|l|}{4.97} \\
\hline Oxidatian/Reduction (mv) & \multicolumn{3}{|l|}{88.7} & \multicolumn{3}{|l|}{93.7} \\
\hline Tenperature (degrees C) & \multicolumn{3}{|l|}{14.32} & \multicolumn{3}{|l|}{15.64} \\
\hline Turbidity (NTU) & \multicolumn{3}{|l|}{3.69} & \multicolumn{3}{|l|}{6} \\
\hline $\mathrm{pH}$ & \multicolumn{3}{|l|}{7.86} & \multicolumn{3}{|l|}{7.01} \\
\hline Inorgantes ( $(\mathrm{b} / \mathrm{L} / \mathrm{L})$ & \multicolumn{2}{|l|}{ Result } & Det. Limit & \multicolumn{2}{|l|}{ R:esult } & Det. Limit \\
\hline Nitrate (as N) & \multirow{2}{*}{\multicolumn{2}{|c|}{$\begin{array}{c}0.38 \\
0.0025 \mathrm{~B}\end{array}$}} & 0.02 & \multicolumn{2}{|l|}{0.71} & 0.02 \\
\hline Uranium & & & 0.000009 & 0.01 & & 0.0000046 \\
\hline Organles ( $\mu$ g/L) & Resnlt & & Det. Limit & Resultt & & Det. LImit \\
\hline I,I,I-Trichlorochlate, & 5 & & 5 & 5 & & 5 \\
\hline Betryene & 5 & & 5 & 2 & & 2 \\
\hline cis-1,2-Dichloroethene? & 5 & & 5 & 5 & & 5 \\
\hline Methylene Chloride & 4 & & 5 & 1 & & 2 \\
\hline Tetrachloroethene & 5 & & 5 & 2 & & 2 \\
\hline Ttichloroethese: & 5 & & 5 & 2 & & 2 \\
\hline Aadioanalytes (pCIL) & Result & $\overline{\text { TPU }}$ & MDA & Result & TPU & MDA \\
\hline Apha activily & 1.18 & 1.01 & 1.78 & 4.77 & 2.27 & 2.37 \\
\hline Beta activity & 3.64 & 1.9 & 3.59 & 6.33 & 2.38 & 3.91 \\
\hline Technetium-99 & 2.05 & 3.75 & 624 & 4.81 & 4.17 & 6.63 \\
\hline Uranium-234 & 0.564 & 0.321 & 0.204 & 0.743 & 0.546 & 0.628 \\
\hline Uraniem-235 & 0.0482 & 0.168 & 0.131 & 0.137 & 0.294 & 0.458 \\
\hline Uranium-23g & 0.932 & 0.422 & 0.204 & 0.0617 & 0.294 & 0.661 \\
\hline
\end{tabular}


APPENDIX D

CY 2007 RCRA POST-CLOSURE GROUNDWATER MONITORING DATA

FOR THE UPPER EAST FORK POPLAR CREEK HYDROGEOLOGIC REGIME 


\title{
EXPLANATION
}

\section{SAMPLE TYPE;}

Dup = field duplicate sample (Table 2 only)

\section{UNITS:}

Degrees $\mathrm{C}=$ water temperature in degrees of the Celsius scale

$\hat{n}=$ feet; elevations are above mean sea level and depth to water is the distance from the measuring point

$\mu \mathrm{g} / \mathrm{L}=$ micrograms per liter

$\mu$ mhorcm $=$ micromhos per centimeter

$\operatorname{mg} / \mathrm{L}=$ miligrams per liter

$\mathrm{mV}=$ millivolts

$\mathrm{NTU}=$ nephelometric turbidity units

$\mathrm{pCi} / \mathrm{L}=$ picoCuries per liter

ppm ㅍ parts per million

\section{DATA QUALIFIERS:}

B = also detected in the associated method blank (organics)

[C] = uranium concentration was calculated frorn isotopic uraniurn results (GW-108)

$\mathrm{J}=$ positively identified, estimated value below the quantitation level (organics)

$\mathrm{U}=$ nol detected at or above the project quantitation level

\section{NOTES:}

\author{
- not analyzed \\ Enor = total propagated uncertainty (two standard deviations) (radiochemistry) \\ MDA = minimum detectable activity (radiochemistry)
}


This page intentionally left blank.

D.4 


\section{Appendix D: CY 2007 RCRA Post-Closure Groundwater Monitoring Data for the Upper East Fork Poplar Creek Hydrogeologic Regime}

Tennessee Permit Number: TNHW-113

Tobje 1. S-3 Site Point-of-Compliance

\begin{tabular}{|c|c|c|c|c|c|}
\hline \multirow{2}{*}{$\begin{array}{r}\text { Well } \\
\text { Dale Stampied } \\
\end{array}$} & \multicolumn{5}{|c|}{ GW-108 } \\
\hline & \multicolumn{2}{|l|}{$01 / 04 / 07$} & \multicolumn{3}{|c|}{$07 / 1007$} \\
\hline Fleld Measurements & Result & & Ressitt & & \\
\hline Tirne Sampled & 14:00 & & $9: 15$ & & \\
\hline Measuring Point Elev. (ft) & 999.00 & & 999.00 & & \\
\hline Depth to Water (t) & 6.98 & & 7.27 & & \\
\hline Groundwater Elsvation (ft) & 992.02 & & 991.73 & & \\
\hline Conductivity ( $\mu m$ ho/km) & 55,700 & & 55,500 & & \\
\hline Dissolved Oxygen (ppm) & 4.48 & & 0.72 & & \\
\hline Oxidation/Reduction (mV) & 298 & & 157 & & \\
\hline Temperanture (degrees C) & 19.2 & & 22 & & \\
\hline Turbidity (NTU) & 0 & & 2 & & \\
\hline $\mathrm{pH}$ & 5.56 & & 5.42 & & \\
\hline Inorgenles (mol) & Result & Det. LImft & Result & & Det. Limll \\
\hline Bariun & 75.2 & 0.06 & 71.7 & & 0.05 \\
\hline Cadmium & $0.012 \mathrm{U}$ & 0.012 & $0.0015 \mathrm{U}$ & & 0.00144 \\
\hline Chromiums & $0.06 \mathrm{U}$ & 0.06 & $0.06 \mathrm{U}$ & & 0.06 \\
\hline Mereuny & $0.0002 \mathrm{U}$ & 0.0002 & $0.0002 \mathrm{U}$ & & 0.0002 \\
\hline Nickel & 0.196 & 0.12 & 0.182 & & 0.12 \\
\hline Nitrale (as N) & 6,580 & 400 & 6,370 & & 200 \\
\hline Uranium & $0.0166[\mathrm{C}]$ & 0 & $0.0143[\mathrm{C}$ & & 0 \\
\hline Organies (atr) & Result & Det. Lonit & Result & & Det. Limlt \\
\hline Acctone & $9 \mathrm{BJ}$ & 10 & 81 & & 10 \\
\hline Chlorotorm & 34 & 5 & 35 & & 5 \\
\hline cis-1,2-Dichloroethene & $5 \mathrm{U}$ & 5 & $5 \mathrm{U}$ & & 5 \\
\hline Melhytene chloride & so B & 5 & $48 \mathrm{~B}$ & & 2 \\
\hline Tetrachlorocthene & $4 \mathrm{~J}$ & 5 & 4 & & 2 \\
\hline Trichioroethene & $4 \mathrm{~J}$ & 5 & 3 & & 2 \\
\hline Radionnalytes (pClL) & Reavilt & MDA & Ressilt & TPU & MDA \\
\hline Alpha achvity & 80.4 & 70 & 68.9 & 38.2 & 555 \\
\hline Beta activity & 18,400 & 105 & 14,900 & 2390 & 102 \\
\hline Technetiumz-99 & 30,000 & 6.43 & 29,000 & 4,620 & 10.7 \\
\hline
\end{tabular}


Appendix D: CY 2007 RCRA Post-Closure Groundwater Mobitoring Data for the Upper East Fork Poplar Creek Hydrogeologic Regime

Tennessee Pernit Number: 'TNHW-113

Table 2. Plume boundary monitoring locations

\begin{tabular}{|c|c|c|c|c|c|c|c|c|c|c|c|c|}
\hline \multirow{3}{*}{$\begin{array}{r}\text { Well } \\
\text { Dute Ssmpled } \\
\text { Sample Type }\end{array}$} & \multicolumn{6}{|c|}{ CW-193 } & \multirow{2}{*}{\multicolumn{6}{|c|}{$\frac{\text { GW-605 }}{01 / 030^{4}}$}} \\
\hline & \multicolumn{3}{|c|}{$01 / 04 / 07$} & \multicolumn{3}{|c|}{ ontog/th } & & & & & & \\
\hline & & & & & & & & & & \multicolumn{3}{|c|}{ Dup } \\
\hline Field Measuremeits & \multicolumn{3}{|l|}{ Result } & \multicolumn{3}{|c|}{ Resplt } & \multicolumn{2}{|l|}{ Result } & & \multicolumn{3}{|l|}{ Result } \\
\hline Time Sampled & \multicolumn{3}{|l|}{$9: 40$} & \multicolumn{3}{|c|}{ 9:30 } & \multicolumn{3}{|l|}{$13: 55$} & \multicolumn{3}{|l|}{. } \\
\hline Measuring Point Elev. (A) & \multicolumn{3}{|l|}{934.17} & \multicolumn{3}{|c|}{934.17} & \multicolumn{3}{|l|}{919.06} & \multicolumn{3}{|l|}{, } \\
\hline Depth to Water $(\mathrm{f})$ & \multicolumn{3}{|l|}{9.18} & \multicolumn{3}{|c|}{9.78} & \multicolumn{3}{|l|}{11.25} & \multicolumn{3}{|l|}{ - } \\
\hline Groundwater Elevation ( $\mathrm{ft}$ ) & \multicolumn{3}{|l|}{924.99} & \multicolumn{3}{|c|}{924.39} & \multicolumn{3}{|l|}{907.81} & \multicolumn{3}{|l|}{. } \\
\hline Conductivity (jmthovem) & \multicolumn{3}{|l|}{825} & \multicolumn{3}{|c|}{1,222} & \multicolumn{3}{|l|}{374} & \multicolumn{3}{|l|}{, } \\
\hline Dissolved Oxygen (ppm) & \multicolumn{3}{|l|}{ 2.01 } & \multicolumn{3}{|c|}{2.46} & \multicolumn{3}{|l|}{1.43} & \multicolumn{3}{|l|}{. } \\
\hline Oxidation/Reduction (mV) & \multicolumn{3}{|l|}{220} & 3 & & & 121 & & & . & & \\
\hline Tempetalure (degrees C) & 11.5 & & & 25 . & & & 16.1 & & & . & & \\
\hline Turbidity (NTU) & 1 & & & & & & 2 & & & . & & \\
\hline pkt & 7,6 & & & 7.4 & & & 7.11 & & & . & & \\
\hline Radioang[ytes (pCLL) & Result & TPU & MWA & Result & TPU & MAA & Result & TPU & MDA & Result & TPU & MTA \\
\hline Techtnetium-99 & 1.69 & 3.57 & 5.97 & 3.47 & 3.62 & 5.85 & 1.23 & 3.67 & 6.19 & 1.09 & 3.55 & 6 \\
\hline
\end{tabular}

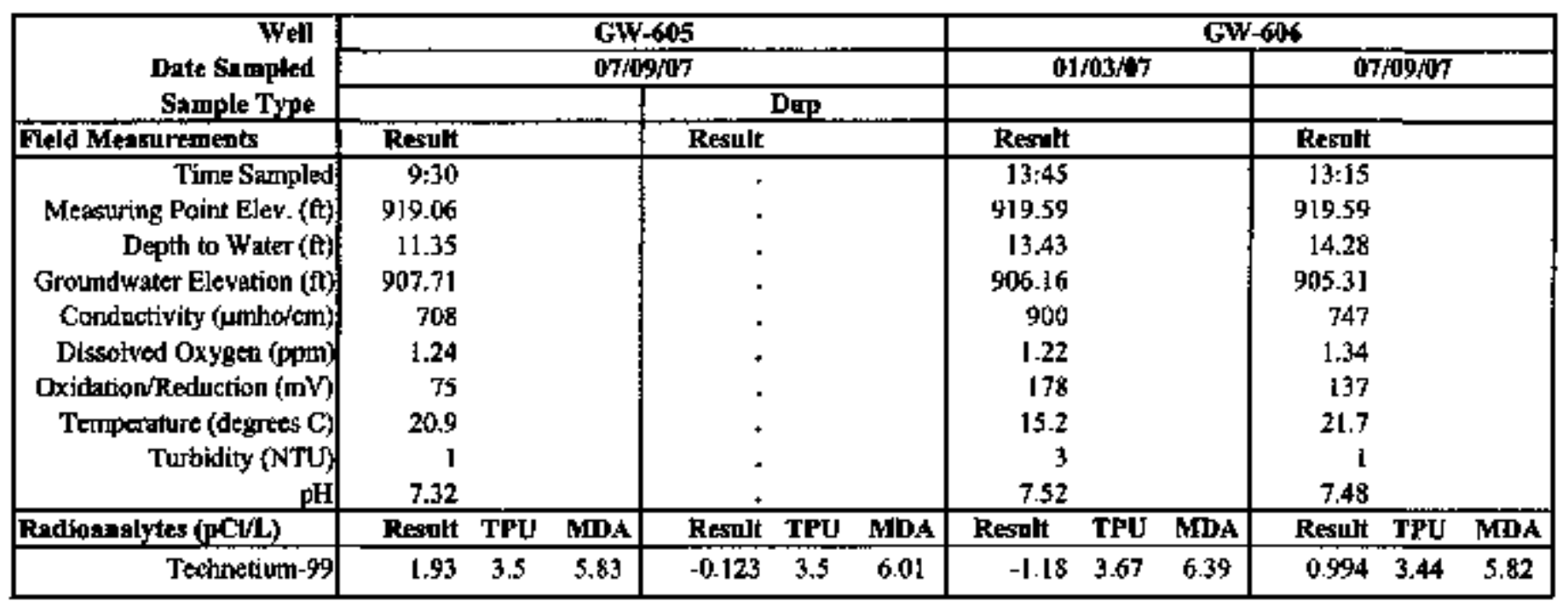

\begin{tabular}{|c|c|c|c|c|c|c|}
\hline \multirow{2}{*}{\begin{tabular}{|r|} 
Well \\
Date Sompled \\
Sumpie Type \\
\end{tabular}} & \multicolumn{6}{|c|}{ GW-733 } \\
\hline & \multicolumn{3}{|c|}{$01 / 04 / 07$} & \multicolumn{3}{|c|}{$07 / 69 / 07$} \\
\hline Fleld Measurenonts & Result & & & Result & & \\
\hline Time Sampled | & $9: 30$ & & & 14:15 & & \\
\hline Measuring Point Elev. (ft) & 959.94 & & & 959.84 & & \\
\hline Depth to Water (ft) & 57.58 & & & 59.81 & & \\
\hline Groundwater Elevation (ft) & 902.26 & & & 900.03 & & \\
\hline Conductivity (unhorcm) & 210 & & & 209 & & \\
\hline Dissolved Oxygen (ppm) & 7.34 & & & 2.01 & & \\
\hline Oxidation/Reduction (mV) & 188 & & & 130 & & \\
\hline Tempetature (degrees C) & 9.6 & & & 27.2 & & \\
\hline Twrbidity (NTU) & 1 & & & 4 & & \\
\hline $\mathrm{pH}$ & 7.53 & & & 7.81 & & \\
\hline Radioanalytes (pCl/L) & Result & TPU & MDA & Reswit & TPU & MDA \\
\hline Technetium-99 & 0.87 & 3.51 & 5.95 & 0.314 & 3.45 & 5.9 \\
\hline
\end{tabular}




\section{APPENDIX E \\ CY 2007 RCRA POST-CLOSURE GROUNDWATER MONTTORING DATA FOR THE CHESTNUT RIDGE HYDROGEOLOGIC REGIME}




\section{EXPLANATION}

\section{LOCATION:}

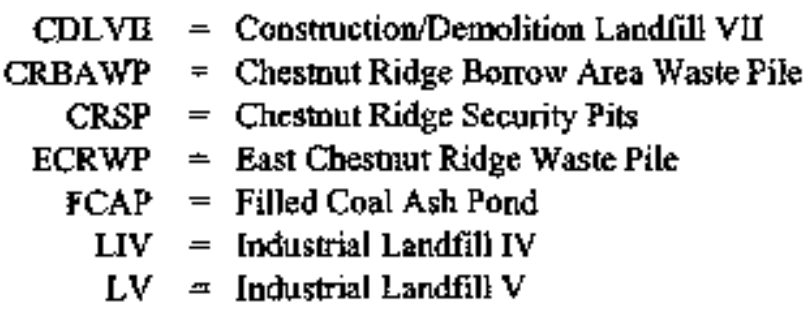

SAMPLE TYPE:

$$
\text { Dup = field duplicate sample }
$$

\section{UNITS:}

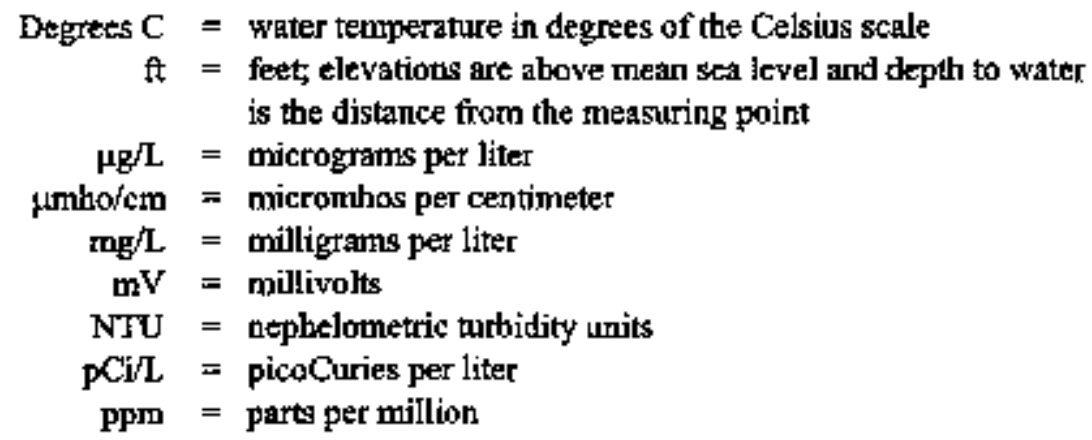

\section{DATA QUALIFIERS:}

\section{All Analvites:}

$$
\mathrm{U}=\text { not detected at or above the project quantitation level }
$$

Bold typt = result exceeds background value (detection monitoring)

lngrranics:

B = less than the project quantitation level but above the instrument detection limit

I = estimated value

\section{Qrganics:}

$$
\begin{aligned}
& \mathrm{B}=\text { also detected in the associated method blank } \\
& J=\text { positively identified, estimated value below the quantitation level }
\end{aligned}
$$

\section{NOTES:}

$$
\text { - = not analyzed }
$$

TPU = total propagated uncertainty (two standard deviations) (radiochemistry)

MDA = minimum detectable activity (radiochemistry) 
APPENDIX E.1

\section{CHESTNUT RIDGE SECURITY PITS}


Appendix E.1: CY 2007 Post-Clnsure Corrective Action Monitoring Data

for the Chestnut Ridge Security Pits

Teлnessee Permit Number: TNHW-128

Table 1. Upgradjent/Background Well

\begin{tabular}{|c|c|c|c|c|c|}
\hline \multirow{3}{*}{\begin{tabular}{|r|} 
Well \\
Lecation \\
Date Sampled \\
\end{tabular}} & \multicolumn{5}{|c|}{ GW-521 } \\
\hline & \multicolumn{5}{|c|}{ LIV } \\
\hline & \multicolumn{2}{|l|}{$01 / 10 / 07$} & \multicolumn{3}{|c|}{$07 / 12 / 07$} \\
\hline Fleld Measurements & \multicolumn{2}{|l|}{ Ressult } & \multicolumn{3}{|c|}{ Result } \\
\hline Time Sampled & $10: 30$ & & \multicolumn{2}{|l|}{$11: 10$} & \\
\hline Messunting Point Elev. (ft) & $1] 82.88$ & & \multicolumn{2}{|l|}{1182.88} & \\
\hline Depth to Water (ft) & 87.33 & & \multicolumn{2}{|l|}{88.29} & \\
\hline Groundwaler Elev. (ft) & 1095.55 & & \multicolumn{2}{|l|}{1094.59} & \\
\hline Conduchyity (unho/m)] & 367 & & \multicolumn{2}{|l|}{674} & \\
\hline Disso]ved Oxygen $(\mathrm{ppm})$ & 6.01 & & \multicolumn{2}{|l|}{6.15} & \\
\hline Oxidation/Reduction (mV) & 165 & & \multicolumn{2}{|l|}{80} & \\
\hline Temperature (digrees $C$ ) & I5.I & & \multicolumn{2}{|l|}{18.8} & \\
\hline Turbidity (NTU] & 4 & & \multicolumn{2}{|l|}{ I } & \\
\hline $\mathrm{pH}$ & 8.41 & & \multicolumn{2}{|l|}{8.03} & \\
\hline Inorganles (mp/L) & Result & Det. Llmint & Result & & Det. Limit \\
\hline Cectmiuns & $0.00 \mathrm{~L}$ & 0.00004 & 0.0001 & & 0.00004 \\
\hline Chromiun & $0.005 \mathrm{~V}$ & 0.0026 & 0.005 & & 0.0005 \\
\hline Lead & $0.003 \mathrm{v}$ & 0.0026 & 0.003 & & 0.00018 \\
\hline Merciry & $0.0002 \mathrm{U}$ & 0.000027 & 0.0002 & & 0.000027 \\
\hline Nickel & $0.04 \mathrm{v}$ & 0.0078 & $0.0 \mathrm{f}$ & & 0.0003 \\
\hline Uranium & $.0 .0000153 \mathrm{U}$ & 0.00031 & 0.004 & & 0.00062 \\
\hline 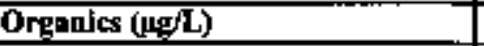 & Result & Det. Limst & Regult & & Deh Limit \\
\hline Berrzene & $5 \mathrm{U}$ & 0.16 & 5 & $\overline{\mathbf{U}}$ & 0.16 \\
\hline Bromoforts & $\mathrm{I} \mathrm{U}$ & 0.19 & 5 & j & 0.19 \\
\hline Carbon tetrachloride & $5 \mathbf{U}$ & 0.19 & 5 & 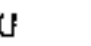 & 0.19 \\
\hline Chloritorm & $\mathbf{I} \mathbf{u}$ & 0.16 & 5 & $U$ & 0.16 \\
\hline 1,1-Dichloroethane & I U & 0.16 & 5 & $U$ & 0.16 \\
\hline 1,1-Dichlorothene & I U & 0.14 & 5 & U & 0.14 \\
\hline 1,2-Dichloroethane & $\mathbf{I}$ & 0.13 & 5 & $U$ & 0.13 \\
\hline cisn 1,2-Dichloroetbene & $1 \mathrm{U}$ & 0.15 & 5 & U & 0.15 \\
\hline Irans-1,2-Dichloroelhene & $0.5 \mathrm{U}$ & 0.15 & 5 & $U$ & 0.15 \\
\hline Tetrachlorothene & I U & 0.2 & 5 & $\mathrm{U}$ & 0.2 \\
\hline I,I,1-Trichlozoethane & I U & 0.16 & 5 & $U$ & O.EG \\
\hline Trichlorothenc & I U & 0.16 & 5 & & 0.56 \\
\hline Vinyl chloride & I U & 0.17 & 2 & $U$ & 0.17 \\
\hline Radioanalytes (pCi/L) & Result TPU & $\mathrm{MDA}$ & Resalt & TPU & MIA \\
\hline Alpha activity & 1.3 & 1.9 & -0.1 & 0.65 & 1.8 \\
\hline Beta activity & 1.4 & 23 & 0.6 & 1 & 2.2 \\
\hline
\end{tabular}


Appendix E.1: CY 2007 Post-Closure Correcllve Action Monitoring Data

for the Chestnut Ridge Security Pits

Tennessee Per'mit Number: TNHW-128

Table 2. Point-of-Compliance Well

\begin{tabular}{|c|c|c|c|c|c|c|}
\hline \multirow{3}{*}{\begin{tabular}{|r|} 
Wel \\
Locatlon \\
Date Sampled \\
\end{tabular}} & \multicolumn{6}{|c|}{ GW-177 } \\
\hline & \multicolumn{6}{|c|}{ CRSP } \\
\hline & \multicolumn{3}{|c|}{$01 / 09 / 07$} & \multicolumn{3}{|c|}{$6 / 11 / 07$} \\
\hline Fiekd Measurements & \multicolumn{3}{|l|}{ Resalt } & \multicolumn{3}{|l|}{ Result } \\
\hline Time Sampled & \multicolumn{3}{|l|}{$12: 55$} & \multicolumn{3}{|l|}{$9: 25$} \\
\hline Measuring Point Elev. (t) & \multicolumn{3}{|l|}{1158.20} & \multicolumn{3}{|l|}{1158.20} \\
\hline Depth to Water (t) & \multicolumn{3}{|l|}{ I 19.42} & \multicolumn{3}{|l|}{519.19} \\
\hline Groundweter Elev. (fi) & \multicolumn{3}{|l|}{1038.78} & \multicolumn{3}{|l|}{1039.01} \\
\hline Conductivity ( $\mu \mathrm{mho} / \mathrm{cm})$ & \multicolumn{3}{|l|}{192} & \multicolumn{3}{|l|}{495} \\
\hline Disnolyed Oxygen (ppm) & \multicolumn{3}{|l|}{7.41} & \multicolumn{3}{|l|}{3.78} \\
\hline Oxidation'Reduction ( $\mathrm{mV}$ ) & \multicolumn{3}{|l|}{105} & \multicolumn{3}{|l|}{134} \\
\hline Teriperature (degres C) & \multicolumn{3}{|l|}{13.9} & \multicolumn{3}{|l|}{21.6} \\
\hline Turbidity (NTU) & \multicolumn{3}{|l|}{1} & \multicolumn{3}{|l|}{1} \\
\hline $\mathrm{pH}$ & \multicolumn{3}{|l|}{7.3} & \multicolumn{3}{|l|}{3.54} \\
\hline Inorganies (mg/L) & Result & & Det. Lfinait & Resalt & & Det. Limit \\
\hline Couminizm & 0.001 & & 0.001 & 0.0002 & & 0.00012 \\
\hline Chromium & 0.0127 & & 0.005 & 0.0194 & & 0.005 \\
\hline Lead & 0.003 & & 0.003 & 0.002 & & 0.002 \\
\hline Mercury & 0.0002 & & 0.0002 & 0.0002 & & 0.0002 \\
\hline Nickel] & 0.0113 & & 0.01 & 0.0134 & & 0.01 \\
\hline Uraniun & 0.0011 & & 0.000009 & 0.0011 & & 0.0000059 \\
\hline Organtes (p & Result & & Det. Limit & Resuli & & Det. Limit \\
\hline Betrzene & 5 & & 5 & 2 & & 2 \\
\hline Bromoform & 5 & & $s$ & 5 & & 5 \\
\hline Carbon tetrachloridt & 5 & & 5 & 2 & & 2 \\
\hline Chloroform & 5 & & 5 & 5 & & 5 \\
\hline I,l-Dichlorothene & 26 & & 5 & 25 & & 5 \\
\hline 1,1-Dichloroethene & 5 & & 5 & 6 & & 3 \\
\hline 1,2-Dichlorothente & 5 & & 5 & 2 & & 2 \\
\hline cis-1,2-Dichloroethene & 5 & & 5 & 5 & & 5 \\
\hline trans-1,2-Dieblorothene & 5 & & 5 & 5 & & 5 \\
\hline Tetrachloroethene & 5 & & 5 & 2 & & 2 \\
\hline $1,1,1$-Trichloroethene & 8 & & 5 & 7 & & 5 \\
\hline Trichloroethene & 5 & & 5 & 2 & & 2 \\
\hline Vinly chloride & 2 & & 2 & 1 & & $\mathbf{I}$ \\
\hline Radionnalytes (pCill) & Result & TPU & MDA & Result & TPU & MDA \\
\hline Alpha activity & 1.57 & 1.48 & 2.62 & 2.73 & 1.56 & 2.14 \\
\hline Beta activity & 3.57 & 2.04 & 3.88 & 2.72 & 1.85 & 3.67 \\
\hline
\end{tabular}




\section{Appendix E.1: CY 2007 Post-Closure Correctlve Action Monitoring Data \\ for the Chestut Ridge Security Pits \\ Tennessee Permit Number: TNYW-128}

Table 3. Plume Delineation Wells

\begin{tabular}{|c|c|c|c|c|c|c|c|c|}
\hline \multirow{4}{*}{$\begin{array}{r}\text { Sampling Pènt } \\
\text { boctaton } \\
\text { Date Sanpled } \\
\text { Somple Type }\end{array}$} & \multicolumn{4}{|c|}{ GW-301 } & \multicolumn{4}{|c|}{ GW-301 } \\
\hline & \multirow{2}{*}{\multicolumn{4}{|c|}{ CRBAWP }} & \multicolumn{4}{|c|}{ CRBAWP } \\
\hline & & & & & \multicolumn{4}{|c|}{$07 / 12 / \%$} \\
\hline & \multicolumn{4}{|c|}{$01 / 09,07$} & & & \multicolumn{2}{|c|}{ Dup } \\
\hline Field Measurements & Result & & Result & & Resnlt & & Result & \\
\hline Time Sarnpled & $12: 55$ & & & & $12: 55$ & & \multicolumn{2}{|l|}{ 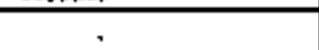 } \\
\hline Measuring Point Elcv. (tt) & 1086.55 & & \multicolumn{2}{|l|}{.} & 1086.55 & & \multicolumn{2}{|l|}{. } \\
\hline Depth to Water (ft) & 135.43 & & \multicolumn{2}{|l|}{. } & 136.03 & & \multicolumn{2}{|l|}{. } \\
\hline Groundwater Ekw. (ft) & 951.12 & & . & & 950.52 & & \multirow{2}{*}{\multicolumn{2}{|c|}{. }} \\
\hline Conductivity $(\mu \mathrm{mho} / \mathrm{cm})$ & 786 & & \multicolumn{2}{|l|}{. } & 284 & & & \\
\hline Dissolved Oxygen (ppm) & 5.4 & & \multicolumn{2}{|l|}{ + } & 9.19 & & \multicolumn{2}{|l|}{. } \\
\hline Oxidntion/Retuction $(\mathrm{m} V)^{\prime}$ & 124 & & \multirow{2}{*}{\multicolumn{2}{|c|}{$\cdot$}} & $24 i$ & & \multicolumn{2}{|l|}{. } \\
\hline Temperature (dcgtees C) & 12.8 & & & & 21.3 & & . & \\
\hline Turbidity (NTU)] & I & & \multicolumn{2}{|l|}{ " } & 12 & & \multicolumn{2}{|l|}{. } \\
\hline $\mathrm{pH}$ & 7.96 & & & 7.93 & & \multicolumn{2}{|l|}{+} \\
\hline Organles ( $\mu$ : & Result & Det. Linit & Result & Det. Limit & Result & Det. Limitt & Result & Det. Linit \\
\hline Велzene & $5 \mathrm{U}$ & 5 & 50 & 5 & $2 U$ & 2 & 20 & 2 \\
\hline Bromofom & 50 & $s$ & $5 \mathrm{U}$ & 5 & $5 \mathrm{U}$ & 5 & $5 \mathrm{U}$ & 5 \\
\hline Carbor tetrachloride & 50 & 5 & SU & 5 & $2 U$ & 2 & $2 \mathrm{U}$ & 2 \\
\hline Chlorofom & $s U$ & 5 & $5 \mathrm{v}$ & $s$ & $5 \mathrm{U}$ & 5 & $5 \mathrm{U}$ & 5 \\
\hline 1,1-Dichloroethame & 50 & 5 & $5 \mathrm{U}$ & 5 & $5 \mathrm{U}$ & 5 & $5 \mathrm{U}$ & 5 \\
\hline 1,1-Dichtoroethene & $5 U$ & 5 & $5 \mathrm{v}$ & $s$ & $3 \mathrm{U}$ & 3 & $3 \mathrm{U}$ & 3 \\
\hline 1,2-Dichloroethane & 50 & 5 & $5 \mathrm{U}$ & 5 & $2 \mathrm{U}$ & 2 & $2 \mathrm{U}$ & 2 \\
\hline cif-1,2-Dictloroethene & 5 U & 5 & $5 \mathrm{U}$ & 5 & $5 \mathrm{U}$ & 5 & $5 \mathrm{U}$ & 5 \\
\hline trans-1,2-Dichloroethene & $5 \mathrm{U}$ & 5 & $s \mathrm{U}$ & 5 & $5 \mathrm{U}$ & 5 & $5 \mathrm{U}$ & 5 \\
\hline Tetrachloroethene & $5 U$ & 5 & $5 \mathrm{v}$ & 5 & $2 \mathrm{U}$ & 2 & $2 U$ & 2 \\
\hline 1,1,1-Trichloroethane & $5 \mathrm{U}$ & $s$ & $5 \mathrm{U}$ & $s$ & $5 \mathrm{U}$ & 5 & $5 \mathrm{U}$ & 5 \\
\hline TrichJoroethethe & $5 \mathrm{U}$ & 5 & $5 U$ & 5 & 20 & 2 & $2 \mathrm{U}$ & 2 \\
\hline Vinyl chloride & $2 \mathrm{U}$ & 2 & 20 & 2 & $1 \mathrm{U}$ & $\mathbf{I}$ & $1 \mathrm{U}$ & 1 \\
\hline
\end{tabular}




\section{Appendix E.1: CY 2007 Post-Closnre Corrective Action Monitoring Data \\ for the Chestnut Ridge Security Pits \\ Tennessee Pernnit Number; TNHW-128}

Table 3. (continued)

\begin{tabular}{|c|c|c|c|c|c|c|c|c|}
\hline \multirow{3}{*}{$\begin{array}{r}\text { Sampline Polnt } \\
\text { Location } \\
\text { Dote Simpled } \\
\text { Sxmple Type }\end{array}$} & \multirow{2}{*}{\multicolumn{4}{|c|}{$\frac{\text { GW-557 }}{\mathrm{LV}}$}} & \multicolumn{4}{|c|}{ GW-562 } \\
\hline & & & & & \multicolumn{4}{|c|}{ CDLVII } \\
\hline & \multicolumn{2}{|c|}{$01 / 11 / 07$} & \multicolumn{2}{|c|}{$07 / 6.07$} & \multicolumn{2}{|c|}{ OE/16iont } & \multicolumn{2}{|c|}{$97 / 17 / 07$} \\
\hline Fitld Measuremements & Result & & Result & & Result & & Retult & \\
\hline Time Sampled & $10: 10$ & & $12: 45$ & & $9: 35$ & & $10: 15$ & \\
\hline Mcasuring Point Elev. (fi) & 1081.36 & & $\operatorname{tog} 1.36$ & & 934.69 & & 934.69 & \\
\hline Depth to Water (ft) & 125.28 & & 125.51 & & 13.87 & & $15 \mathrm{AO}$ & \\
\hline Groundwater Elev, (ft) & 956.08 & & 955.85 & & 920.82 & & 919.29 & \\
\hline Conductivity ( $\mu-m h o / c m)$ & 352 & & 205 & & 440 & & 236 & \\
\hline Dissolved Oxygen (ppm) & 11.12 & & 9.28 & & 6.53 & & 4.63 & \\
\hline Oxidalion/Reduction (mv) & 176 & & 105 & & 213 & & 228 & \\
\hline Temperature (degrees C) & 14.6 & & 19.8 & & 12.2 & & 17.1 & \\
\hline Turtidity (NTU) & 2 & & 9 & & l & & 68 & \\
\hline $\mathrm{pH}$ & 7.66 & & 7.72 & & 7.74 & & 7.71 & \\
\hline Organies $(\mu \mathrm{g} / \mathrm{L})$ & Ressilt & Det. Limit & Feanlt & Det. Limint & Resnle & Det. Limit & Result & Def. Limit \\
\hline Benzene & $5 \mathrm{U}$ & 0.16 & $5 \mathrm{U}$ & 0.16 & $5 \mathrm{U}$ & 0.16 & 50 & 0.16 \\
\hline Bromafom & $1 \mathrm{U}$ & 0.19 & $5 \mathrm{U}$ & 0.19 & ] $U$ & 0.19 & $5 \mathrm{U}$ & 0.59 \\
\hline Carton tetrachloride & $5 \mathrm{U}$ & 0.19 & $5 \mathrm{U}$ & 0.19 & $S \mathrm{U}$ & 0.19 & $5 \mathrm{U}$ & 0.19 \\
\hline Chlotoform & I U & 0.16 & $5 \mathrm{U}$ & 0.16 & $\mathrm{IU}$ & 0.16 & 50 & 0.16 \\
\hline 1,1-Dichloroethane & $1 \mathrm{U}$ & 0.16 & S U & 0.16 & $1 \mathrm{U}$ & 0.16 & $5 \mathrm{U}$ & 0.16 \\
\hline 1,1-Dirhlorpelhene & 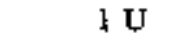 & 0.14 & $5 \mathrm{u}$ & 0.14 & 10 & 0.14 & $5 \mathrm{U}$ & 0.14 \\
\hline 1,2-Dichloroethane & $1 \mathrm{U}$ & 0.13 & $5 \mathrm{U}$ & 0.13 & $1 \mathrm{U}$ & 0.13 & 50 & 0.13 \\
\hline cis-1,2-Dichloroethene & $1 \mathrm{U}$ & 0.15 & $5 \mathrm{U}$ & 0.15 & $\mathrm{IU}$ & 0.15 & $5 \mathrm{U}$ & 0.15 \\
\hline trans-1,2-Dichloroethene & $0.5 \mathrm{U}$ & 0.15 & $5 \mathrm{U}$ & 0.15 & 0.50 & 0.15 & $5 \mathrm{U}$ & 0.15 \\
\hline Tetrachlorocthene & $1 \mathrm{U}$ & 0.2 & $5 \mathrm{U}$ & 0.2 & $\mathbf{I} \mathrm{U}$ & 0.2 & $5 \mathrm{U}$ & 0.2 \\
\hline 1,1,1-Trichloroethane & $1 \mathrm{v}$ & 0.16 & $5 \mathrm{U}$ & 0.16 & $1 \mathrm{U}$ & 0.16 & $5 \mathrm{U}$ & 0.16 \\
\hline Trichloroethenc| & 10 & 0.16 & $5 \mathrm{U}$ & 0.16 & 10 & 0.16 & S U & 0.16 \\
\hline Vinyl chleride & 10 & 0.17 & $2 \mathrm{U}$ & 0.17 & 10 & 0.17 & $2 \mathrm{u}$ & 0.17 \\
\hline
\end{tabular}




\section{Appendir E.1: CY 2007 Post-Closure Corrective Action Mónitoring Data \\ for the Chestnut Ridge Security PIts \\ Tennessee Permit Number: TNHW-128}

Table 3. (continued)

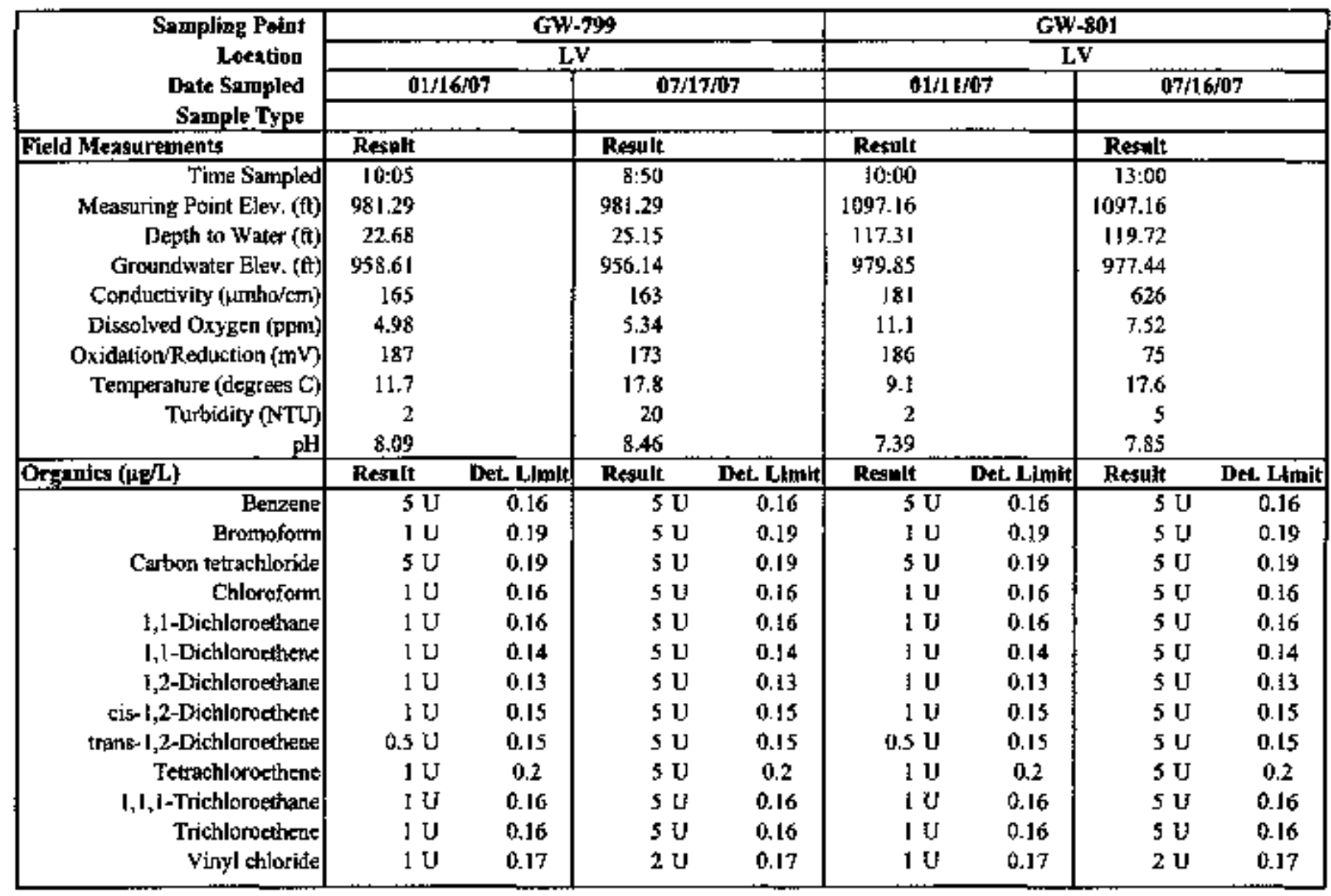


Appendix E.1: CY 2007 RCRA Post-Closure Corrective Action Monitoring Data

for the Chestnut Ridge Security Pits

Tennessee Permit Namber: TNHW-128

Table 3. (continued)

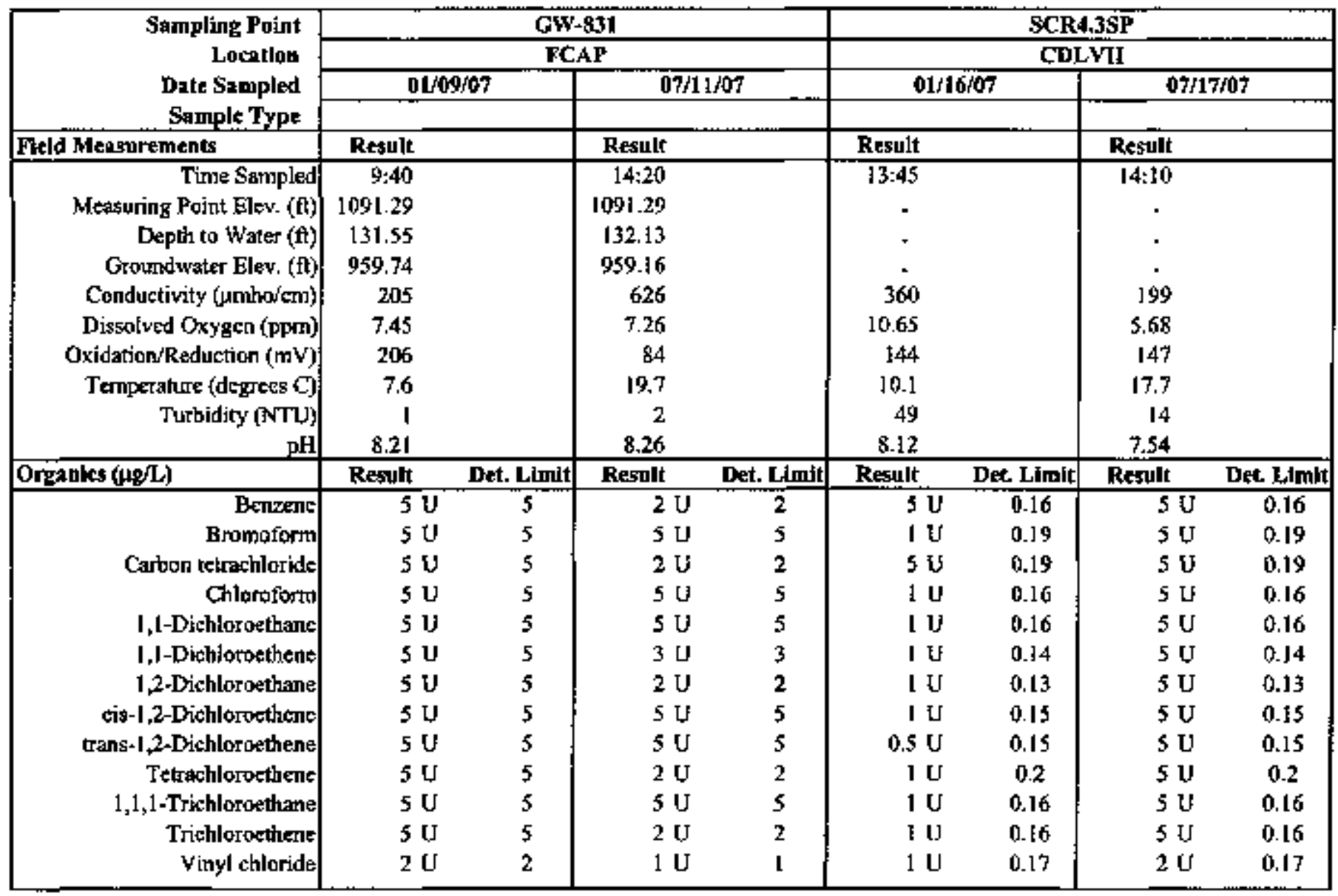


APPENDIX E.2

CHESTNUT RIDGE SEDIMENT DISPOSAL BASIN 
Appendix E.2: CY 2007 RCRA Post-Closure Detection Monitoring Dath

for the Chestnut Ridge Sedlment Disposal Basin

Tenmessee Permit Number: TNHW-128

Table 1. Target coustltuents

\begin{tabular}{|c|c|c|c|c|c|}
\hline \multirow{4}{*}{\begin{tabular}{|r|} 
Monttering Purpese \\
Well \\
Date Sampled \\
Sample Type
\end{tabular}} & Upgradient & \multicolumn{4}{|c|}{ Pojat of Compliance } \\
\hline & GW-159 & & GW-731 & $G \times-732$ \\
\hline & $01 / 0 \mathrm{~B}$ N07 & \multicolumn{2}{|c|}{$01 / 08 / 07$} & $01 / 09 / 07$ & DI/09/07 \\
\hline & & & Dup & & \\
\hline \multicolumn{6}{|l|}{ Field Measurements } \\
\hline Time Sampled & $13: 35$ & $13: 10$ & . & $9: 25$ & $13: 15$ \\
\hline Measuring Point Elev, (ft) & 1051.40 & $\mathbf{1 0 4 9 . 3 0}$ & . & 1049.38 & 1064.29 \\
\hline Depth to Water (ft) & 118.00 & 143.56 & . & $125.21)$ & 157.63 \\
\hline Groundwater Elev. (ft) & 933.40 & 905.74 & . & 924.18 & 906.66 \\
\hline Conductivity (umho/cm) & 438 & 362 & . & 269 & 369 \\
\hline Dissolved Oxygen (ppm) & 6.62 & 10.03 & . & 5.75 & 6.88 \\
\hline Oxidation/Reduction (mV) & 230 & 58 & . & 197 & 161 \\
\hline Temperature (degrees C) & 12.1 & 11.2 & . & $₫ 1$ & 14.2 \\
\hline Turbidity (NTU) & 2 & 1) & . & 17 & 1 \\
\hline $\mathrm{pH}$ & 7.84 & 7.32 & - & 8.3 & 7.62 \\
\hline \multicolumn{6}{|l|}{ Target Constituents (me/L) } \\
\hline Cadmiun & $0.001 \mathrm{U}$ & $0.001 \mathrm{U}$ & $0.001 \mathrm{U}$ & $0.001 \mathrm{U}$ & $0,001 \mathrm{U}$ \\
\hline Clnomiun & $0.005 \mathrm{U}$ & $0.005 \mathrm{U}$ & $0.005 \mathrm{U}$ & $0.005 \mathrm{U}$ & $0.005 \mathrm{U}$ \\
\hline Lead & $0.003 \mathrm{U}$ & $0.003 \mathrm{U}$ & $0.003 \mathrm{U}$ & $0.003 \mathrm{U}$ & $0.003 \mathrm{U}$ \\
\hline Meтcuгy & $0.0002 \mathrm{U}$ & $0.0002 \mathrm{U}$ & $0.0002 \mathrm{U}$ & $0.0002 \mathrm{U}$ & $0.0002 \mathrm{U}$ \\
\hline Nickel & $0.01 \mathrm{U}$ & $0.01 \mathrm{U}$ & $0.01 \mathrm{U}$ & $0.01 \mathrm{U}$ & $0.01 \mathrm{U}$ \\
\hline Silver & $0.004 \mathrm{v}$ & $0.004 \mathrm{U}$ & $0.004 \mathrm{U}$ & $0.004 \mathrm{U}$ & $0.004 \mathrm{U}$ \\
\hline Uranium & $0.0012 \mathrm{~B}$ & $0.002 \mathrm{~B}$ & $0,0021 \mathrm{~B}$ & $0.0003 \mathrm{~B}$ & $0.00022 \mathrm{~B}$ \\
\hline
\end{tabular}


APPENDIX E.3

KERR HOLLOW QUARRY 
Appendix E.3: CY 2007 RCRA Post-Closure Detection Monitoring Data

for Kerr Hollow Quarry

Tennessee Permit Number: TNHW-128

Tabłe 1. Inorganic and organic constituents

\begin{tabular}{|c|c|c|c|c|c|}
\hline \multirow{4}{*}{$\begin{array}{r}\text { Montitoring Purpose } \\
\text { well } \\
\text { Date Sampled } \\
\text { Spmple Type }\end{array}$} & \multirow{2}{*}{\multicolumn{2}{|c|}{$\begin{array}{c}\text { Upgradtent/Background } \\
\text { GW-231 }\end{array}$}} & \multicolumn{3}{|c|}{ Pojnt of Compliance } \\
\hline & & & \multirow{3}{*}{$\begin{array}{l}\text { GW-143 } \\
01 / 08 / 07 \\
\end{array}$} & \multirow{3}{*}{$\begin{array}{l}\text { GW-144 } \\
01 / 04 / 07 \\
\end{array}$} & \multirow{3}{*}{$\begin{array}{l}\text { GW-145 } \\
01 / 08 / 07 \\
\end{array}$} \\
\hline & \multicolumn{2}{|c|}{$01 / 04 / 07$} & & & \\
\hline & & Dup & & & \\
\hline \multicolumn{6}{|l|}{ Field Messurements } \\
\hline Time Sampled & $13: 45$ & . & $10: 20$ & $15: 10$ & $9: 55$ \\
\hline Mcusuring Foint Elev. (ft) & 849.67 & - & 913.98 & 913.54 & 840.24 \\
\hline Depth to Water (ft) & 17.44 & . & 81.65 & 82.1 & 7.05 \\
\hline Groundwater Elevation ( $\mathrm{ft}$ ) & 832.23 & - & 832.33 & 831.44 & 833.19 \\
\hline Conductivity (umho/cm) & 257 & . & 278 & 233 & 681 \\
\hline Dissolved Oxygen (ppm) & 3.08 & . & 4.34 & 7.36 & 4.48 \\
\hline Oxidation/Reduction (mV) & 129 & . & -124 & 132 & 198 \\
\hline Temperahte (degrees C) & 14.3 & + & 9.8 & 14.6 & 8.5 \\
\hline Turbidity (NTU) & 3 & - & 1 & 1 & 1 \\
\hline $\mathrm{pH}$ & 7.26 & . & 7.73 & 7.5 & 7.7 \\
\hline \multicolumn{6}{|l|}{ Intrganics (mg/L) } \\
\hline Cadmiun & $0,001 \mathrm{U}$ & $0.001 \mathrm{U}$ & $0.001 \mathrm{U}$ & $0.001 \mathrm{U}$ & $0.001 \mathrm{~J}$ \\
\hline Chromium & $0.005 \mathrm{U}$ & $0.005 \mathrm{U}$ & $0.005 \mathrm{U}$ & $0.005 \mathrm{U}$ & $0.005 \mathrm{U}$ \\
\hline Lead & $0.003 \mathrm{U}$ & $0.003 \mathrm{U}$ & $0.003 \mathrm{U}$ & $0.003 \mathrm{U}$ & $0,003 \mathrm{U}$ \\
\hline Mercury & $0.0002 \mathrm{U}$ & $0.0002 \mathrm{U}$ & $0.0002 \mathrm{U}$ & $0.0002 \mathrm{U}$ & $0.0002 \mathrm{U}$ \\
\hline Nickel & $0.01 \mathrm{U}$ & $0.01 \mathrm{U}$ & $0.01 \mathrm{U}$ & $0.01 \mathrm{U}$ & $0.01 \mathrm{U}$ \\
\hline Uranium & $0.00043 \mathrm{~B}$ & $0.00043 \mathrm{~B}$ & $0.00035 \mathrm{~B}$ & $0.0011 \mathrm{~B}$ & 0.012 \\
\hline \multicolumn{6}{|l|}{ Organic Compounds $\{\mu \rho / L)$} \\
\hline Carbon tetrachloride & $5 \mathrm{U}$ & $5 \mathrm{U}$ & $5 \mathrm{U}$ & $5 \mathrm{U}$ & $5 \mathrm{U}$ \\
\hline Chlorofortb & $5 \mathrm{U}$ & $5 \mathrm{U}$ & $5 U$ & $5 \mathrm{U}$ & $5 \mathrm{U}$ \\
\hline Tetrachlonethene & $5 \mathrm{U}$ & $5 \mathrm{U}$ & $5 \mathrm{U}$ & $5 \mathrm{U}$ & $5 U$ \\
\hline
\end{tabular}


Appendix E.3: CY 2007 RCRA Post-Closure Detection Monitoring Datz

for Kerr Hollow Quarty

Tennessee Permit Number: TNHW-128

Table 2. Radiochemical constituents

\begin{tabular}{|c|c|c|c|c|c|c|c|c|}
\hline \multirow{2}{*}{$\begin{array}{l}\text { Monitaring } \\
\text { Purpose }\end{array}$} & \multirow{2}{*}{ Well } & \multirow{2}{*}{$\begin{array}{c}\text { Date } \\
\text { Sampled }\end{array}$} & \multicolumn{3}{|c|}{ Gross Alpha Activity (pCi/L) } & \multicolumn{3}{|c|}{ Gross Beta Artivity (pCi/L) } \\
\hline & & & Result & TPU & MDA & Result & TPU & MDA \\
\hline \multirow{2}{*}{$\begin{array}{l}\text { Lpgradient } \\
\text { Backeround }\end{array}$} & GW-23I & $01 / 0407$ & 1.63 & 1.43 & 2.4 & 4.27 & 2.16 & 3.98 \\
\hline & GW-23! Dup & $01 / 04 / 07$ & 0.673 & 1.12 & 2.38 & 2.85 & 1.95 & 3.9 \\
\hline \multirow{3}{*}{$\begin{array}{l}\text { Point of } \\
\text { Compliance }\end{array}$} & GW-143 & $01 / 08 / 07$ & 3.72 & 1.87 & 2.26 & 15.1 & 3.63 & 3.94 \\
\hline & GW-IA4 & $01 / 04 / 07$ & 2.47 & 1.7 & 2.45 & 2.94 & 1,96 & 3.85 \\
\hline & GW-145 & $01 / 08 / 07$ & 12.50 & 3.66 & 2.22 & 9.97 & 2.95 & 4.04 \\
\hline
\end{tabular}


APPENDIX E.4

EAST CEESTNUT RIDGE WASTE PILE 
Appendix E.4: CY 2007 RCRA Post-Closure Detection Monstoring Data

for the East Chestaut Ridge Waste Pile,

Tennessee Pernlt Number: TNHW-128

Table 1. Inorganic and organic constituents

\begin{tabular}{|c|c|c|c|c|c|c|}
\hline \multirow{4}{*}{$\begin{array}{r}\text { Monitioring Purpose } \\
\text { Well } \\
\text { bate Sampled } \\
\text { Sample Type }\end{array}$} & \multirow{2}{*}{\multicolumn{2}{|c|}{$\begin{array}{l}\text { Upgradient/Backgronnd } \\
\text { GW-29d }\end{array}$}} & \multicolumn{4}{|c|}{ Point af Complance } \\
\hline & & & \multicolumn{2}{|c|}{ GW-161 } & \multicolumn{2}{|c|}{ GW-292 } \\
\hline & $01 / 22 / 07$ & $07 / 1107$ & $01 / 25 / 07$ & $07 / 10 / 07$ & $01 / 23 / 07$ & $0 / 007$ \\
\hline & & & & & & \\
\hline \multicolumn{7}{|l|}{ Fkeld Messarements } \\
\hline Time Sampled & 10:45 & $13: 30$ & $13: 25$ & $\mid 4: 20$ & $9: 30$ & $9: 35$ \\
\hline Measuring Point Elev. (ft) & 1083.60 & 1083.60 & 1093.54 & 1093.54 & 1073.00 & 1073.00 \\
\hline Depth to Water (ft) & 95.70 & 101.73 & 160.12 & $\mathbf{1 6 1 . 9 8}$ & 113.54 & IIS.51 \\
\hline Groundwster Elevation (ft) & 987.90 & 981.87 & 933.42 & 931.56 & 959.46 & 957.49 \\
\hline Conductivity (umho/cm) & 575 & 487 & 800 & 936 & 502 & 576 \\
\hline Dissolved Oxygen (ppm) & 9.65 & 5.84 & 8,01 & 4.49 & 7.4 & 3.35 \\
\hline Oxidation/Reduction (mV) & 292 & 155 & 104 & 87 & 2]1 & 180 \\
\hline Temperature (degrets C) & 13.8 & 23.5 & 14.2 & 17.6 & 12.7 & 17.3 \\
\hline Turbidity (NTU) & 1 & I] & 6 & 17 & 3 & 5 \\
\hline pH & 7.42 & 7.56 & 7.6 & 7.96 & 7.52 & 7.58 \\
\hline \multicolumn{7}{|l|}{ Inorganjes (mg/L) } \\
\hline Antimiony & $0.006 \mathrm{U}$ & $0.003 \mathrm{U}$ & $0.006 \mathrm{~V}$ & $0.003 \mathrm{U}$ & $0.006 \mathrm{U}$ & $0.003 \mathrm{U}$ \\
\hline Arsenic & $0,005 \mathrm{U}$ & $0.005 \mathrm{v}$ & $0.005 \mathrm{U}$ & 0.005 녀 & $0.005 \mathrm{U}$ & $0.005 \mathrm{U}$ \\
\hline Barium & 0.0127 & 0.012 & 0.0148 & 0.0143 & 0.116 & 0.103 \\
\hline Boron & $0.01 \mathrm{U}$ & $0.01 \mathrm{U}$ & $0.01 \mathrm{U}$ & $0.01 \mathrm{U}$ & $0.01 \mathrm{U}$ & $0.01 \mathrm{U}$ \\
\hline Cadtrium & $0.001 \mathrm{U}$ & $0.00012 \mathrm{U}$ & 0.001 it & 0.0002 & $0.001 \mathrm{U}$ & $0.00012 \mathrm{U}$ \\
\hline Chloride & 13.5 & 9.6 & 2.6 & 2.6 & 11.5 & 10.5 \\
\hline Chromium & $0.005 \mathrm{~J}$ & $0.005 \mathrm{u}$ & $0.005 \mathrm{H}$ & $0.005 \mathrm{U}$ & $0.0 \mathrm{i}$ & 0.0257 \\
\hline Cobalt & $0.005 \mathrm{U}$ & $0.005 \mathrm{U}$ & $0.005 \mathrm{vt}$ & $0.005 \mathrm{U}$ & $0.005 \mathrm{U}$ & $0.005 \mathrm{U}$ \\
\hline Coppes & $0.005 \mathrm{U}$ & $0.005 \mathrm{v}$ & $0.005 \mathrm{v}$ & $0.005 \mathrm{U}$ & $0.005 \mathrm{U}$ & 0.0055 \\
\hline Iron & 0.0217 & 0.0181 & 2.59 & 4.14 & 0.21 & 0.588 \\
\hline Lead & $0.003 \mathrm{U}$ & $0.002 \mathrm{U}$ & $0.003 \mathrm{U}$ & $0.002 \mathrm{U}$ & $0.003 \mathrm{U}$ & $0.002 \mathrm{U}$ \\
\hline Lithium & $0.01 \mathrm{u}$ & $0.01 \mathrm{u}$ & $0.01 \mathrm{U}$ & $0.01 \mathrm{U}$ & $0.01 \mathrm{u}$ & $0.0] \mathrm{U}$ \\
\hline Mangamest & $0.005 \mathrm{U}$ & $0.005 \mathrm{U}$ & 0.0079 & 0.262 & $0.005 \mathrm{U}$ & 0.0114 \\
\hline Mercury & $0.0002 \mathrm{v}$ & $0.0002 \mathrm{U}$ & $0.0002 \mathrm{U}$ & $0.0002 \mathrm{u}$ & $0.0002 \mathrm{U}$ & $0.0002 \mathrm{U}$ \\
\hline Nickel & $0.01 \mathrm{U}$ & $0.01 \mathrm{U}$ & $0.01 \mathrm{U}$ & $0.01 \mathrm{v}$ & 0.0541 & 0.0747 \\
\hline Nitrate (as $\mathrm{N}$ ) & 1.7 & 1.3 & 0.22 & $0.02 \mathrm{v}$ & 0.39 & 0.35 \\
\hline Sclcoíur & $0.005 \mathrm{U}$ & $0.0025 \mathrm{U}$ & $0.005 \mathrm{U}$ & $0.0025 \mathrm{U}$ & $0.005 \mathrm{U}$ & $0.0025 \mathrm{U}$ \\
\hline Sulfate & 2.9 & 2.6 & 1.5 & 0.58 & 4.1 & 4.5 \\
\hline Thallium & $0.002 \mathrm{U}$ & $0.002 \mathrm{U}$ & $0.002 \mathrm{U}$ & $0.002 \mathrm{Ut}$ & $0.002 \mathrm{U}$ & $0.002 \mathrm{U}$ \\
\hline Uranium & $0.00016 \mathrm{~B}$ & $0.00014 \mathrm{~B}$ & $0.00035 \mathrm{~B}$ & $0.000086 \mathrm{~B}$ & $0.0002 \mathrm{~B}$ & $0.00041 \mathrm{~B}$ \\
\hline $\operatorname{Zinc}$ & $0.01 \mathrm{U}$ & 0.0 & $0.01 \mathrm{v}$ & $0.01 \mathrm{D}$ & $0.01 \mathrm{U}$ & $0.01 \mathrm{U}$ \\
\hline \multicolumn{7}{|l|}{ Organic Compounds (utz) } \\
\hline Benzense & $5 \mathrm{v}$ & $2 \mathrm{U}$ & $5 \mathrm{v}$ & 2 U & $5 \mathrm{U}$ & $2 \mathrm{U}$ \\
\hline Carbon Tetrachloride & $5 \mathrm{U}$ & $2 \mathrm{v}$ & $5 \mathrm{O}$ & $2 \mathrm{U}$ & 5 U & $2 \mathrm{v}$ \\
\hline Chloroform & $5 \mathrm{Ul}$ & $5 \mathrm{Ul}$ & $5 \mathrm{U}$ & $5 \mathrm{U}$ & $5 \mathrm{Ul}$ & $5 \mathrm{U}$ \\
\hline Chloromethane & 100 & $10 \mathrm{U}$ & $10 \mathrm{U}$ & $10 \mathrm{U}$ & $10 \mathrm{u}$ & 100 \\
\hline 1,1-Dichlorocthanc & $5 \mathrm{U}$ & $5 \mathrm{uf}$ & $5 \mathrm{U}$ & $5 \mathrm{U}$ & $5 \mathrm{U}$ & $5 \mathrm{u}$ \\
\hline 1,1-Dichloroethene & 5 바 & $3 \mathrm{U}$ & $5 \mathrm{U}$ & 30 & $5 \mathrm{U}$ & $3 \mathrm{y}$ \\
\hline 1,2-Dichloroethane & $5 \mathrm{U}$ & $2 \mathrm{U}$ & SU & $2 \mathrm{U}$ & $5 \mathrm{U}$ & $2 U$ \\
\hline cis-1,2-Dichlorothente & 50 & 50 & $5 \mathrm{U}$ & 50 & $5 \mathrm{U}$ & $5 \mathrm{U:}$ \\
\hline trans-1,2-Dichloroethene & $5 \mathrm{U}$ & $5 \mathrm{U}$ & $5 \mathrm{U}$ & $5 \mathrm{U}$ & $5 \mathrm{U}$ & $5 \mathrm{U}$ \\
\hline Methylene Chloride & $4 \mathrm{BJ}$ & $2 \mathrm{U}$ & I BJ & 2 บी & $3 \mathrm{BJ}$ & 15 \\
\hline Tetrachloroethene & sul & $2 \mathrm{U}$ & sul & 2 녀 & $5 \mathrm{U}$ & $2 \mathrm{v}$ \\
\hline $1,1,1$-Trichloroethane & $5 \mathrm{U}$ & $5 \mathrm{U}$ & 50 & $5 \mathrm{U}$ & $5 \mathrm{U}$ & 50 \\
\hline Trichlorothene & $5 u$ & $2 \mathrm{v}$ & 50 & $2 \mathrm{U}$ & $5 \mathrm{U}$ & $2 v$ \\
\hline Vinyl Chloride & $2 \mathrm{U}$ & $1 \mathrm{U}$ & $2 \mathrm{U}$ & $1 \mathrm{U}$ & $2 \mathrm{Ut}$ & 10 \\
\hline
\end{tabular}




\section{Appendix E.4: CY 2007 RCRA Post-Closure Detection Monitoring Data for the East Chestnut Ridge Waste Pile, Tennessee Permit Number: TNHW-128}

Table 1 (continued)

\begin{tabular}{|c|c|c|c|c|c|c|c|c|}
\hline \multirow{4}{*}{$\begin{array}{r}\text { Moattoring Purpose } \\
\text { Wen } \\
\text { Date Sampied } \\
\text { Sample Type }\end{array}$} & \multicolumn{8}{|c|}{ Point of Complinnce } \\
\hline & \multicolumn{4}{|c|}{ GW-293 } & \multicolumn{2}{|c|}{ GW-296 } & \multicolumn{2}{|c|}{ GW-298 } \\
\hline & \multicolumn{2}{|c|}{$01 / 24 / 07$} & \multicolumn{2}{|c|}{$07 / 19 / 07$} & \multirow[t]{2}{*}{$01 / 22 / 07$} & \multirow[t]{2}{*}{$6 / 10 / 07$} & \multirow[t]{2}{*}{$01 / 29 / 07$} & \multirow[t]{2}{*}{$07 / 09 / 07$} \\
\hline & & Dup & & Dup & & & & \\
\hline Field Measurements & & & & & & & & \\
\hline Time Sampled & $10: 15$ & . & $9: 35$ & - & $13: 50$ & $13: 10$ & $10: 30$ & $13: 15$ \\
\hline Measuring Point Elev. ( $\mathbf{t})$ & 1063.90 & + & 1063.90 & . & 1090.99 & 1090.99 & 1049.01 & 1049.01 \\
\hline Depth to Water (nt) & 115.99 & . & 117.59 & . & $\mathrm{I} 18.5 \mathrm{I}$ & 119.66 & ] 09.25 & 110.92 \\
\hline Groundwalet Elevation (ft) & 947.91 & . & 946.31 & - & 972.48 & 971.33 & 939.76 & 938.09 \\
\hline Conductivity $(\mu m \mathrm{ho} / \mathrm{cm})$ & 658 & . & 320 & + & $\$ 10$ & 55.1 & 677 & 672 \\
\hline Dissolved Oxyget (ppm) & 14.58 & - & 2.3 & . & 7.1 & 4.29 & 6.61 & $2.3 \mathrm{~B}$ \\
\hline Oxidation/Reduction (mV) & 243 & + & 248 & . & 207 & 134 & 189 & 20 \\
\hline Temperaturt (degrees C) & 13.1 & . & 20.5 & . & 14.1 & 16.7 & 5.1 & 24.2 \\
\hline Turtidity (NTU) & 6 & . & 100 & . & 0 & 2 & 3 & 3 \\
\hline & 7.33 & . & 7.5? & . & 7.54 & 7.5 & 7.81 & 8.07 \\
\hline rganies (mgit) & & & & & & & & \\
\hline Antimony & $0.006 \mathrm{U}$ & $0.006 \mathrm{U}$ & $0.003 \mathrm{U}$ & $0.003 \mathrm{U}$ & $0.006 \mathrm{U}$ & $0.003 \mathrm{U}$ & 0.006 प & $0.003 \mathrm{U}$ \\
\hline Arsenic & $0.005 \mathrm{U}$ & $0.005 \mathrm{U}$ & $0.005 \mathrm{U}$ & $0.005 \mathrm{U}$ & $0.005 \mathrm{U}$ & $0.005 \mathrm{U}$ & 0.005 나 & $0.005 \mathrm{U}$ \\
\hline Barium & 0.204 & 0.203 & 0.165 & 0.157 & 0.0108 & 0.olotal & 0.0172 & 0.0147 \\
\hline Boron & $0.01 \mathrm{U}$ & $0.01 \mathrm{U}$ & $0.01 \mathrm{U}$ & $0.01 \mathrm{U}$ & $0.01 \mathrm{U}$ & $0.01 \mathrm{U}$ & $0.01 \mathrm{U}$ & $0.01 \mathrm{U}$ \\
\hline Cadmium & $0.001 \biguplus$ & $0.001 \mathrm{U}$ & $0.00012 \mathrm{U}$ & $0.00012 \mathrm{U}$ & $0.001 \mathrm{\nu}$ & $0.00012 \mathrm{U}$ & $0.001 \mathrm{U}$ & $0.00012 \mathrm{U}$ \\
\hline Chloride & $15+2$ & 14.6 & 14.4 & 14.3 & 3.4 & 3.4 & & 0.98 \\
\hline Chromium & $0.005 \mathrm{U}$ & $0.005 \mathrm{U}$ & $0.005 \mathrm{v}$ & $0.005 \mathrm{U}$ & $0.005 \mathrm{v}$ & $0.005 \mathrm{U}$ & $0.005 \mathrm{U}$ & 0.0083 \\
\hline Cobalt & $0.005 \mathrm{U}$ & $0.005 \mathrm{v}$ & $0.005 \mathrm{U}$ & $0.005 \mathrm{v}$ & $0.005 \mathrm{U}$ & $0.005 \mathrm{U}$ & $0.005 \mathrm{U}$ & $0.005 \mathrm{U}$ \\
\hline Copper & $0.005 \mathrm{U}$ & $0.005 \mathrm{U}$ & $0.005 \mathrm{v}$ & $0.005 \mathrm{U}$ & $0.005 \mathrm{U}$ & $0.005 \mathrm{v}$ & $0.005 \mathrm{U}$ & $0.005 \mathrm{U}$ \\
\hline Iron & 0.561 & 0.488 & 7.97 & 4.02 & 0.0199 & $0.01 \mathrm{U}$ & 0.0184 & $0.01 \mathrm{U}$ \\
\hline Lead & $0.003 \mathrm{U}$ & $0.003 \mathrm{U}$ & $0.002 \mathrm{U}$ & $0.002 \mathrm{U}$ & $0.003 \mathrm{U}$ & $0.002 \mathrm{U}$ & $0.003 \mathrm{v}$ & $0.002 \mathrm{U}$ \\
\hline Lithium & $0.01 \mathrm{U}$ & $0.01 \mathrm{U}$ & $0.0 \mathrm{u}$ & $0.01 \mathrm{v}$ & $0.01 \mathrm{U}$ & 0.01 U & $0.0 \mathrm{H} \mathrm{U}$ & $0.01 \mathrm{U}$ \\
\hline Marigantse & 0.0954 & 0.095 & 0.101 & $0.101]$ & $0,005 \mathrm{U}$ & 0.005 us & $0.005 \mathrm{U}$ & $0.005 \mathrm{U}$ \\
\hline Mercury & 0.0002 ป & $0.0002 \mathrm{U}$ & $0.0002 \mathrm{U}$ & $0.0002 \mathrm{v}$ & 0.0002 u & $0.0002 \mathrm{v}$ & $0.0002 \mathrm{u}$ & $0.0002 \mathrm{U}$ \\
\hline Nicke] & $0.01 \mathrm{U}$ & $0.01 \mathrm{U}$ & $0.01 \mathrm{U}$ & $0.01 \mathrm{v}$ & $0.01 \mathrm{U}$ & $0.01 \mathrm{U}$ & $0.01 \mathrm{U}$ & $0.01 \mathrm{U}$ \\
\hline Nitrale (as N) & 0.28 & 0.31 & 0.028 & 0.026 & 0.6 & 0.15 & & 0.075 \\
\hline Seletsium & $0.005 \mathrm{U}$ & $0.005 \mathrm{v}$ & $0.0025 \mathrm{U}$ & $0.0025 \mathrm{U}$ & $0.005 \mathrm{U}$ & 0.0025 U & $0.005 \mathrm{U}$ & $0.0025 \mathrm{U}$ \\
\hline Sulfate & 4.5 & 4.3 & 2.4 & 2.5 & 1.6 & 0.79 & & \\
\hline Thalienn & $0.002 \mathrm{U}$ & $0.002 \mathrm{U}$ & $0.002 \mathrm{U}$ & $0.002 \mathrm{v}$ & $0.002 \mathrm{U}$ & $0.002 \mathrm{U}$ & $0.002 \mathrm{U}$ & $0.002 \mathrm{U}$ \\
\hline Uranium & $0.00054 \mathrm{~B}$ & $0.00052 \mathrm{~B}$ & $0.000072 \mathrm{~B}$ & $0.00013 \mathrm{~B}$ & $0.00014 \mathrm{~B}$ & $0.000094 \mathrm{~B}$ & $0.0013 \mathrm{~B}$ & $0.0015 \mathrm{~B}$ \\
\hline Zinc & $0.0 \mathrm{LU}$ & $0.01 \mathrm{U}$ & $0.01 \mathrm{v}$ & $0.01 \mathrm{u}$ & $0.01 \mathrm{U}$ & $0.01 \mathrm{U}$ & 0.0144 & $0,01 \mathrm{U}$ \\
\hline Organic Compounds (ug/L) & & & & & & & & \\
\hline Benzene & $5 \mathrm{U}$ & su & 20 & 20 & $5 \mathrm{U}$ & $2 \mathrm{U}$ & $5 \mathrm{U}$ & $2 \mathrm{U}$ \\
\hline Carbon Tetrachloride & $5 \mathrm{u}$ & $5 \mathrm{U}$ & 20 & 20 & $5 \mathrm{U}$ & $2 v$ & $5 \mathrm{u}$ & $2 \mathrm{U}$ \\
\hline Chlorofom & $5 \mathrm{U}$ & $5 \mathrm{U}$ & 50 & $5 \mathrm{U}$ & $5 \mathrm{U}$ & $5 \mathrm{U}$ & $5 \mathrm{v}$ & $5 \mathrm{U}$ \\
\hline Chloromethane & $10 \mathrm{U}$ & $10 \mathrm{U}$ & 100 & $10 \mathrm{U}$ & $10 \mathrm{U}$ & $10 \mathrm{U}$ & $10 \mathrm{LS}$ & $10 \mathrm{U}$ \\
\hline 1,1-Dichloroethane & $5 \mathrm{U}$ & $5 \mathrm{U}$ & $5 \mathrm{U}$ & $5 \mathrm{U}$ & 5 uf & $5 \mathrm{U}$ & $5 \mathrm{U}$ & $5 \mathrm{v}$ \\
\hline 1,1-Dichloroethene & $5 \mathrm{~W}$ & $5 \mathrm{U}$ & $3 U$ & $3 \mathrm{U}$ & $5 \mathrm{U}$ & $3 \mathrm{U}$ & $5 \mathrm{U}$ & $3 v$ \\
\hline 1,2-Dichloroethane & $5 \mathrm{U}$ & 50 & 20 & $2 \mathrm{U}$ & $5 \mathrm{U}$ & $2 \mathrm{U}$ & $\leq \mathrm{U}$ & $2 U$ \\
\hline cis-1,2-Díchloroethene & $5 \mathrm{U}$ & $5 \mathrm{U}$ & $5 \mathrm{U}$ & $5 \mathrm{U}$ & $5 \mathrm{U}$ & $5 \mathrm{U}$ & $5 \mathrm{~V}$ & $5 \mathrm{U}$ \\
\hline trans-1,2-Dichlorotthene & $5 \mathrm{U}$ & $5 \mathrm{U}$ & $5 \mathrm{u}$ & $5 \mathrm{U}$ & $5 \mathrm{U}$ & $s \mathrm{u}$ & 50 & $5 \mathrm{U}$ \\
\hline Methylene Chloride & 1 BJ & $1 \mathrm{BJ}$ & $2 \mathrm{~B}$ & $2 \mathrm{~B}$ & $3 \mathrm{BJ}$ & IJ| & $2 \mathrm{BJ}$ & $2 \mathrm{U}$ \\
\hline Tetrachlorottikent & $5 \mathrm{U}$ & $5 \mathrm{U}$ & $2 \mathrm{U}$ & $2 \mathrm{U}$ & $5 \mathrm{U}$ & $2 \mathrm{U}$ & $5 \mathrm{v}$ & $2 \mathrm{Ut}$ \\
\hline I,I,1-Trichloroertane & $5 \mathrm{U}$ & $5 \mathrm{U}$ & $5 \mathrm{U}$ & $5 \mathrm{l}$ & $5 \mathrm{U}$ & $5 \mathrm{U}$ & 504 & $5 \mathrm{U}$ \\
\hline Trichloroethene & 50 & 50 & $2 v$ & $2 \mathrm{Ut}$ & $5 \mathrm{U}$ & $2 \mathrm{v}$ & 5 U & $2 \mathrm{U}$ \\
\hline Vinyl Chloride & $2 \mathrm{U}$ & $2[3]$ & $\mathrm{iv}$ & 1 tht & $2 U$ & $1 \mathrm{v}$ & 20 & 10 \\
\hline
\end{tabular}


Appendix E.4: CY 2007 RCRA Post-Closure Defection Montitoring Data for the East Chestnut Ridige Waste Pile,

Tennessee Per'mit Number: TNHW-128

Table 2. Radiochemical constituents

\begin{tabular}{|c|c|c|c|c|c|}
\hline \multirow{2}{*}{ Monitoring Purpose } & \multirow{2}{*}{ Well } & \multirow{2}{*}{$\begin{array}{c}\text { Date } \\
\text { Samplęd }\end{array}$} & \multicolumn{3}{|c|}{ Gross Alpha Activity (pCi/L) } \\
\hline & & & Regalt & TPU & MDA \\
\hline $\begin{array}{l}\text { Upgradient' } \\
\text { Background }\end{array}$ & $\begin{array}{l}\text { GW-294 } \\
\text { GW-294 }\end{array}$ & $\begin{array}{l}01 / 22 / 07 \\
07 / 11 / 07\end{array}$ & $\begin{array}{l}2.02 \\
0.95\end{array}$ & $\begin{array}{l}1.42 \\
1.28\end{array}$ & 2.09 \\
\hline \multirow{12}{*}{ Poist of Compliatice } & GW-161 & $01 / 25 / 07$ & 0.592 & 1.23 & 2.82 \\
\hline & $G W-161$ & $07 / 10 / 07$ & 1.08 & 1.19 & 2.19 \\
\hline & GW-292 & $01 / 23 / 07$ & $0.90 \mathrm{~s}$ & 1.26 & 2.6 \\
\hline & GW-292 & $07 / 10 / 07$ & 2.23 & 1.82 & 2.99 \\
\hline & $C W-293$ & $01 / 24 / 07$ & 1.04 & 1.26 & 2.47 \\
\hline & GW-299 Dup & $01 / 24 / 07$ & 0.971 & 1.02 & 1.78 \\
\hline & GW-293 & $07 / 1007$ & 0.935 & 1.26 & 2.5 \\
\hline & GW-293 Dup & $07 / 10 / 07$ & -0.379 & 0.746 & 2.51 \\
\hline & GW-296 & $01 / 22 \% 07$ & 0.618 & I.0J & 2.19 \\
\hline & GW-296 & $07 / 1007$ & 0.754 & 1.04 & 2.07 \\
\hline & GW-298 & $01 / 29 / 07$ & 1.89 & 1.50 & 2.53 \\
\hline & GW-298 & $07 / 09 / 07$ & 2.18 & 1.5 & 2.1 \\
\hline
\end{tabular}




\section{APPENDIX E.5}

CY 2007 RCRA POST-CLOSURE DETECTION MONITORING

DATA EVALUATION REPORTS 


\section{CONTENTS}

Summary of Post-Closure Detection Monitoring at the Chestnut Ridge Sediment Disposal Basin, First Semiannugl Reporting Period of Calendar Year 2007.

Summary of Post-Closure Detection Monitoring at Kerr Hoilow Quany,

First Semiannual Reporting Period of Calendar Year 2007

Summary of Post-Closure Detcction Monitoring at East Chestnut Ridge Waste Pile,

First Semiantual Reporting Period of Calendar Year 2007

Summary of Post-Closure Detection Monitoring at East Chestnut Ridge Waste Pile, Second Semiannual Reporting Period of Calendar Year 2007 
This page intentionaliy left blank.

E.5-4 


\section{SUMMARY OF POST-CLOSURE DETECTION MONITORING AT THE CHESTNUT RIDGE SEDIMENT DISPOSAL BASIN, FIRST SEMIANNUAL REPORTING PERIOD OF CALENDAR YEAR 2007}

\subsection{DATA EVALUATION PROCEDURE}

Section 7.4 of post-closure pemit TNHW-128 describes the statistical evaluation of the semianuul Resource Conservation and Recovery Act (RCRA) post-closure detection monitoring results for the following site-specific target list constituents: cadmium, chromium, lead, mercury, nickel, silver, and uranium. The monitoring network at the Chestnut Ridge Sediment Disposal Basin (CRSDB) consists of background well GW-IS9 and point-of-compliance (POC) wells GW-156, GW-73I, and GW-732. The technical approach for the statistical evaluation procedures specificd in Pernit TNHW-128 are presented in Fig. 1 and summarized as follows:

A. Backgronnd Comparison. The analytical results for the CRSDB target list constituents detected in the groundwater samples from each POC are compared to corresponding background values assumed to be representative of uncontaminated groundwater from the uppermost aquifer on Chestnut Ridge. A background value will be determined for each target list constituent for each semiannual monitoring event. Upper tolerance limits (UTLs) to be used as background values will be calculated using data obtained since January 1986 from the designated upgradient wcll(s) at the site. If the monitoring results for each target list constituent do not exced the corresponding background value in each POC well, then a release to groundwater is not indicated and no further statistical testing is performed. If a monitoring result exceeds the cotresponding UTL, one of two evaluation criteria below is applied.

B. Quantitative Trend Anglysis. If the concentration of a target list constituent in a particular POC well exceeds its corresponding UTL, and the constituent has been detected in at least $15 \%$ of the groundwater samples obtained from the well since January 1991, then a quantitative trend analysis (Kendall-Tau or cquivalent) of time-series data for the particular POC well(s) is required to deteruine if a statistically sigrificant increasing concentration trend is evident. The trend analysis will be completed within 60 days of receiving the laboratory analytical report showing the elevated resalt. Confirmation sampling will be performed within 30 days if the trend analysis shows a statistically significant concentration increase, or if the concentration of a target list compound exceeds the UTL for two successive sampling events.

C. Elevated Result Verifiegtion. Verification sampling will be petformed if the concentration of a target list constituent in a POC well exceeds the comcsponding UTL, but the constituent has been detected in less than $15 \%$ of the groundwater samples obtained from the well since January 199l. The verification sample must be collected from the well within 30 days and analyzed for the constituent(s) of concern. If necessary to ensure collection of a representative sample, the POC well may be redeveloped before verification sampling. Confirmation sampling will be performed within 30 days if verification sampling results support the elevated cencentration of the applicable target list constituent. 


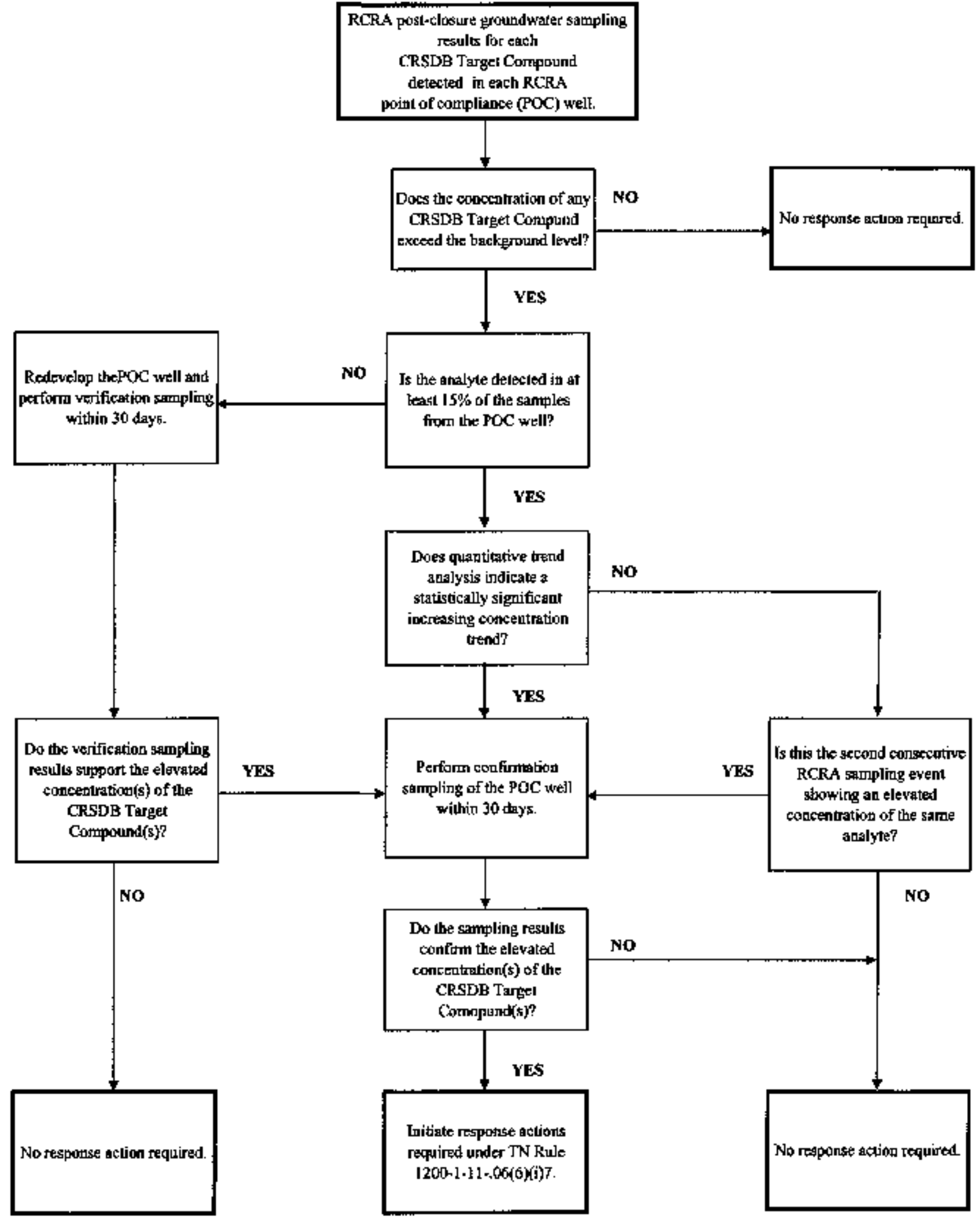

Fig. 1. Technical appronch for evaluation of and response to groundwater qualty data from RCRA detection monituring at the Chestaut RIdge Sediment Disposal Basis. 


\subsection{RESULTS FOR THE FLRST SEMIANNUAL REPORTING PERIOD OF CALENDAR YEAR 2007}

The site-specific background value (UTL) for each target list constituent was determined using data obtained since 1986 for a pool of wells located upgradient of the site and current monitoring results for well GW-159. As shown in the following summary (Table 1), analytical results for the target list constituents in each POC well obtained duning the current monitoring event were then compared to the corresponding background value.

Table 1. Background values determined for the CRSDB compared to monitorlug results

\begin{tabular}{|c|c|c|c|}
\hline Target List Constiluent & $\begin{array}{c}\text { Site-Specific Background } \\
\text { Valuc (mg/L) }\end{array}$ & $\begin{array}{c}\text { Morimum POC } \\
\text { Concentration (mg/L) }\end{array}$ & $\begin{array}{c}\text { POC Well(s) With } \\
\text { Elevated Concentration }\end{array}$ \\
\hline Cadmium & 0.003 & $0.001 \mathrm{U}$ & Nons \\
Chromium & 0.025 & $0.005 \mathrm{U}$ & None \\
Lead & 0.05 & $0.003 \mathrm{U}$ & None \\
Mercury & 0.0002 & $0.0002 \mathrm{U}$ & None \\
Nickel & 0.05 & $0.01 \mathrm{U}$ & None \\
Silver & 0.02 & $0.004 \mathrm{U}$ & None \\
Uranium & 0.004 & $0.002 \mathrm{~J}$ & None \\
\hline Notes: mg/L-milligrams per liter; "U" = not detected at the concentration shown; \\
\hline \multicolumn{2}{|l}{} \\
\hline
\end{tabular}

As shown by the maximum concentration reported for the POC wells during this monitoring event, none of the results exceed the applicable background value (Table 1). Therefore, a release of target list constituents to groundwater is not indicated at the site and no further action is required. 
This page intentionally left blank.

E. 5-8 


\section{SUMMARY OF POST-CLOSURE DETECTION MONITORING AT KERR HOLLOW QUARRY, FIRST SEMIANNUAL REPORTING PERIOD OF CALENDAR YEAR 2007}

\subsection{DATA EVALUATION PROCEDURE}

Section 7.4 of post-closure permit TNHW-128 describes the statistical evaluation of semiannual Resource Conservation and Recovery Act (RCRA) post-closure detection monitoring results for the following sitespecific target list constituents: cadmium, chromium, lead, mercury, nickel, uranium, carbon tetrachloride, tetrachlorethene, chloroform, gross alpha activity, and gross beta activity. The monitoring network at Kerr Hollow Quarry (XHO) consists of background well GW-231 and point-of-compliance (POC) wells GW-143, GW-144, and GW-145. The technical approach for the statistical evaluation procedures specified in Permit TNHW-128 are presented in Fig. 1 and summarized as follows:

C. Background Comparison. The analytical results for the KHQ target list constituents detected in the groundwater samples from each POC are compared to corresponding background values assumed to be representative of uncontanuinated groundwater from the uppermost aquifer on Chestmut Ridge. A background value will be determined for each inorganic target list constituent for each semiannual monitoring event. Upper toletance limits (UTLs) to be used as background values will be calculated using data obtained since January 1986 from the designated upgradient well(s) at the site. Section 7.4.3 of the post-closure permit sets background values for organic compounds at 0 micrograms per liter $(\mu \mathrm{g} / \mathrm{L})$, for gross alpha activity at 15 picoCurits per liter $(\mathrm{pCi} / \mathrm{L}$ ), and for gross beta activity at $50 \mathrm{pCi} / \mathrm{L}$. If the monitoring results for each target list constituent do not exceed the corresponding background value in each POC well, then a release to groundwater is not indicated and no further statistical testing is performed. If a monitoring result exceeds the corresponding background value, then one of two evaluation criteria below is applied.

D. Ougntitative Trend Anglysis. If the concentration of an inorganic or radiological target list constituent in a particular POC well exceeds its corresponding background value, and the constituent has been detected in at least $15 \%$ of the groundwater samples obtained from the well since January 1991, then quantitative trend analysis (Kendall-Tau or equivalent) of timeseries data for the particular POC well(s) is required to determine if a statistically significant increasing concentration trend is evident. The trend analysis will be completed within 60 days of rexeiving the laboratory analytical report showing the elevated result. Confirnation sampling will be performed within 30 days if the frend analysis shows a statisticaliy significant concentration increase, or if the concentration of a target list compound exceeds the background value for two successive sampling events.

C. Elevated Concentration Verification. Verification sampling will be performed if: (1) the concendration of an organic target list constituent in a $\mathrm{POC}$ well is detected (excluding false positives), or (2) an inorganic or radiological target list constituent exceeds the corresponding background value but is detected in less than $15 \%$ of the groundwater samples collected from the well since January 1991. The verification sample must be collected from the well within 30 days and analyzed for the constituent(s) of concern. If necessary to ensure collection of a representative sample, the POC well may be redeveloped before verification sampling. Confirmation sampling will be performed within 30 days if verification sampling results support the elevated concentration of the applicable target list constituent. 


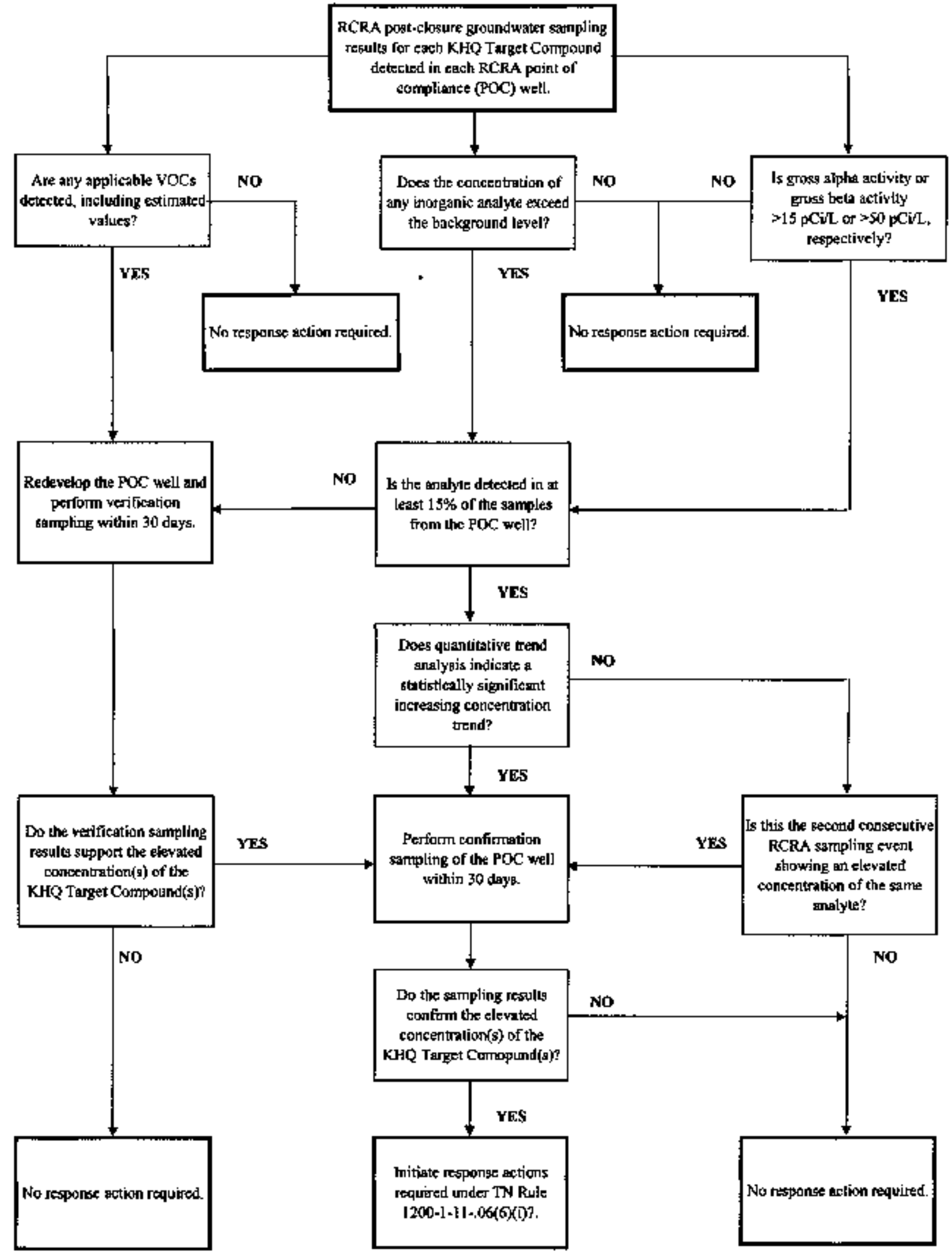

Fig. 1. Technical approach for evaluation of and response to groandwater quallty data from RCRA detection monitoring at Kerr Hollow Quarry.

$$
\text { ES-10 }
$$




\subsection{RESULTS FOR THE FIRST SEMIANNUAL REPORTING PERIOD OF CALENDAR YEAR 2007}

The site-specific background value for each inorganic target list constituent was detemmined using the available pool of upgradient analytical results obtained since 1986 and incorporated current monitoring results for weil GW-231 (Tabie 1). The background values for the organic and radiological target list constituents, as defmed in the post-closure penmit, are also shown below in Table 1. Analytical results for the target list constituents in each POC well obtained during the curtent monitoring event were then compared to the corresponding background value.

Table 1. Background velues deternined for KHQ compared to monitoring results

\begin{tabular}{|c|c|c|c|}
\hline Target List Constituent & $\begin{array}{c}\text { Site-Spectfic } \\
\text { Backgrond Value }\end{array}$ & $\begin{array}{c}\text { Maximum POC } \\
\text { Concentration }\end{array}$ & $\begin{array}{c}\text { POC Wel(s) With } \\
\text { Elevated Concentration }\end{array}$ \\
\hline Inorganics (my/L) & & & \\
\hline $\begin{array}{c}\text { Cadmiam } \\
\text { Cbromium } \\
\text { Lead } \\
\text { Mercury } \\
\text { Nickel } \\
\text { Uranium } \\
\end{array}$ & $\begin{array}{c}0.003 \\
0.011 \\
0.016 \\
0.0002 \\
0.019 \\
0.024 \\
\end{array}$ & $\begin{array}{c}0.001 \mathrm{U} \\
0.005 \mathrm{U} \\
0.003 \mathrm{U} \\
0.0002 \mathrm{U} \\
0.01 \mathrm{U} \\
0.012 \\
\end{array}$ & $\begin{array}{l}\text { None } \\
\text { None } \\
\text { None } \\
\text { None } \\
\text { None } \\
\text { None } \\
\end{array}$ \\
\hline $\begin{array}{c}\text { Orgenics }(\mu \mathrm{p} / \mathrm{L}) \\
\text { Carbon Tetrachloride } \\
\text { Chloroform } \\
\text { Tetrachlorothene }\end{array}$ & $\begin{array}{l}0 \\
0 \\
0\end{array}$ & $\begin{array}{l}5 \mathrm{U} \\
5 \mathrm{U} \\
5 \mathrm{U}\end{array}$ & $\begin{array}{l}\text { None } \\
\text { None } \\
\text { None }\end{array}$ \\
\hline $\begin{array}{l}\text { Radialogtcal (pCi/L) } \\
\text { Gross Alpha Activity } \\
\text { Gross Heta Activity }\end{array}$ & $\begin{array}{l}15 \\
50\end{array}$ & $\begin{array}{l}12.5 \\
15.1\end{array}$ & $\begin{array}{l}\text { None } \\
\text { Nobe }\end{array}$ \\
\hline
\end{tabular}

As shown by the maximum concentration reported for the POC wells during this monitoring event, none of the results exceed the applicable background value (Table 1). Therefore, a release of target list constituents to groundwater is not indicated at the site and no further action is required. 
This page intentionally left blank.

E. 5-12 


\section{SUMMARY OF RCRA POST-CLOSURE DETECTION MONITORING AT THE EAST CHESTNUT RIDGE WASTE PILE, FIRST SEMIANNUAI REPORTING PERIOD OF CALENDAR YEAR 2007}

\subsection{INTRODUCTION}

This report presents an evaluation of the groundwater quality monitoring data obtained at the East Chestnut Ridge Waste Pile (ECRWP) in January 2007. Groundwater monitoring at the site is required by the Resource Conservation and Recovery Act (RCRA) post-closure permit (PCP) for the Chestnut Ridge Hydrogeologic Regime, which was issued by the Temnessee Deparment of Environment and Conservation (TDEC) in Septemter 2006 (TDEC permit no. TNHW-128).

General and site-specific terms and conditions of the PCP, along with the TDEC hazardous waste management regulations incorporated by reference, define the site-specific groundwater sampling and analysis requirements for RCRA post-closure detection monitoring at the ECRWP. Implementation of this monitoring program is intended to provide the data needed to detect a release of contaminants to the uppennost aquifer underlying the site.

\subsection{RCRA GROUNDWATER SAMPLING AND ANALYSIS}

Unfittered groundwater samples were collected during January 2007 from the upgradient/backgtound well (GW-294) and from each of the point-of-compliance (POC) wells (GW-161, GW-292, GW-293, GW-296, and GW-298) that comprise the RCRA well network at the ECRWP. Groundwater samples were collected in accordance with the low-flow minimal drawdown sampling procedure referenced in the PCP.

The PCP requires only three of the POC wells at the ECRWP to be sampled during each semiannual RCRA groundwater sampling event. Nevertheless, all five POC wells were sampled in January 2007 in order to provide more recent monitoring data for these wells, which were last sampled in May 1996.

Groundwater samples collected from the RCRA wells at the ECRWP were aralyzed for the sitespecific suite of RCRA target list constituents designated in the PCP (Table 1), which include 21 inorganic analytes (e.g., metals and anions), 14 volatile organic compounds (VOCs), and gross alpha activity. Laboratory analyses of the groundwater samples were performed in accordance with the approved analytical methosis referenced in the PCP.

\subsection{DATA EVALUATION}

The PCP requires the RCRA post-closure detection monitoring data obtained at the ECRWP to be evaluated in accordance with the procedure flowcharted on Fig. 1. This procedure defines a three-part technical approach whereby: (1) the analytical result for each RCRA target list constifuent detected in each POC is compared to a site-specifte background value; (2) if the anatytical result exceeds the background value for the RCRA target list constituent, quantitative trend analysis of the data for the constituent is performed (if sufficient data are available) to determine if the elevated concentration reflects a statistically siguificant increasing temporal trend; and (3) re-sampling of each applicable POC well to verify the elevated (i.e., >background) and increasing concentration trend evident for the applicable RCRA target list constituent(s). 
Table 1. Background values determined for the ECRWP compared to monitoring results

\begin{tabular}{|c|c|c|c|}
\hline Target List Constituent & $\begin{array}{c}\text { Site-Specific } \\
\text { Background Value }\end{array}$ & $\begin{array}{c}\text { Maximum POC } \\
\text { Concentratlon }\end{array}$ & $\begin{array}{c}\text { POC Well(s) With } \\
\text { Elevated Concentration }\end{array}$ \\
\hline \multicolumn{4}{|l|}{ Inorganies (mg/L) } \\
\hline Antimony & 0.05 & $0.006 \mathrm{U}$ & None \\
\hline Arsenic & 0.05 & $0.005 \mathrm{U}$ & None \\
\hline Barium & 0.043 & 0.204 & $G W-292, G W-293$ \\
\hline Boron & 0.12 & $0.0 \mathrm{IU}$ & None \\
\hline Cadmium & 0.003 & $0.001 \mathrm{U}$ & None \\
\hline Chloride & 10 & 15.2 & $G W-292, G W-293$ \\
\hline Chromiurn & 0.025 & 0.01 & None \\
\hline Cobalt & 0.02 & $0,005 \mathrm{U}$ & None \\
\hline Coppet & 0.027 & $0.005 \mathrm{U}$ & Note \\
\hline Iron & 15 & 2.59 & None \\
\hline Lead & 0.05 & $0.003 \mathrm{U}$ & Note \\
\hline Lithium & 0.026 & $0.01 \mathrm{U}$ & None \\
\hline Manganese & 0.29 & 0.095 & None \\
\hline Mercury & 0.0002 & $0.0002 \mathrm{U}$ & None \\
\hline Nicke1 & 0.05 & 0.0541 & GW-292 \\
\hline Nitrate (as N) & 3 & 0.6 & None \\
\hline Selenium & 0.05 & $0.005 \mathrm{U}$ & None \\
\hline Sulfate & 43 & 6.4 & None \\
\hline Thallium & 0.01 & $0.002 \mathrm{U}$ & None \\
\hline Uranium & 0.004 & $0.0013 \mathrm{~J}$ & None \\
\hline $\operatorname{Zine}$ & 0.12 & 0.0144 & None \\
\hline \multicolumn{4}{|l|}{ Organies ( $\mu \mathrm{g} / \mathrm{L})$} \\
\hline Benzeve & 0 & $5 \mathrm{U}$ & None \\
\hline Carbon Tetrachloride & 0 & $5 \mathrm{U}$ & None \\
\hline Chloroform & 0 & $5 \mathrm{U}$ & None \\
\hline Cbloromethane & 0 & $5 \mathrm{U}$ & None \\
\hline 1,1-Dichloroethane & 0 & $5 \mathrm{U}$ & None \\
\hline 1, l-Dichloroethene & 0 & $5 \mathrm{U}$ & None \\
\hline 1,2-Dicbloroethane & 0 & $5 \mathrm{U}$ & None \\
\hline cis-1,2-Dichloroethene & 0 & $\$ \mathrm{U}$ & None \\
\hline trans-1,2-Dichloroettume & 0 & $5 \mathrm{U}$ & Nonte \\
\hline 1,1,1-Trichloroethane & 0 & $\$ \mathrm{U}$ & None \\
\hline Methylene Chlotide & 0 & $4 \mathrm{BJ}[\mathrm{FP}]$ & Noute \\
\hline Tetrachloroethene & 0 & $5 \mathrm{U}$ & None \\
\hline Trichlotocthene & 0 & $5 \mathrm{U}$ & None \\
\hline Vinyl Chloride & 0 & $2 \mathrm{U}$ & None \\
\hline \multicolumn{4}{|l|}{ Radiological (pCl/L) } \\
\hline Gross Alphs Activity & 15 & SMDA & None \\
\hline \multicolumn{4}{|c|}{ 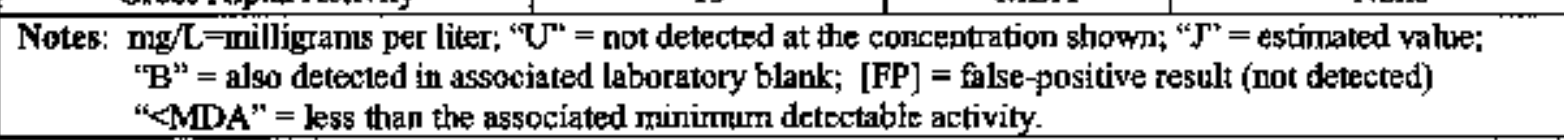 } \\
\hline
\end{tabular}




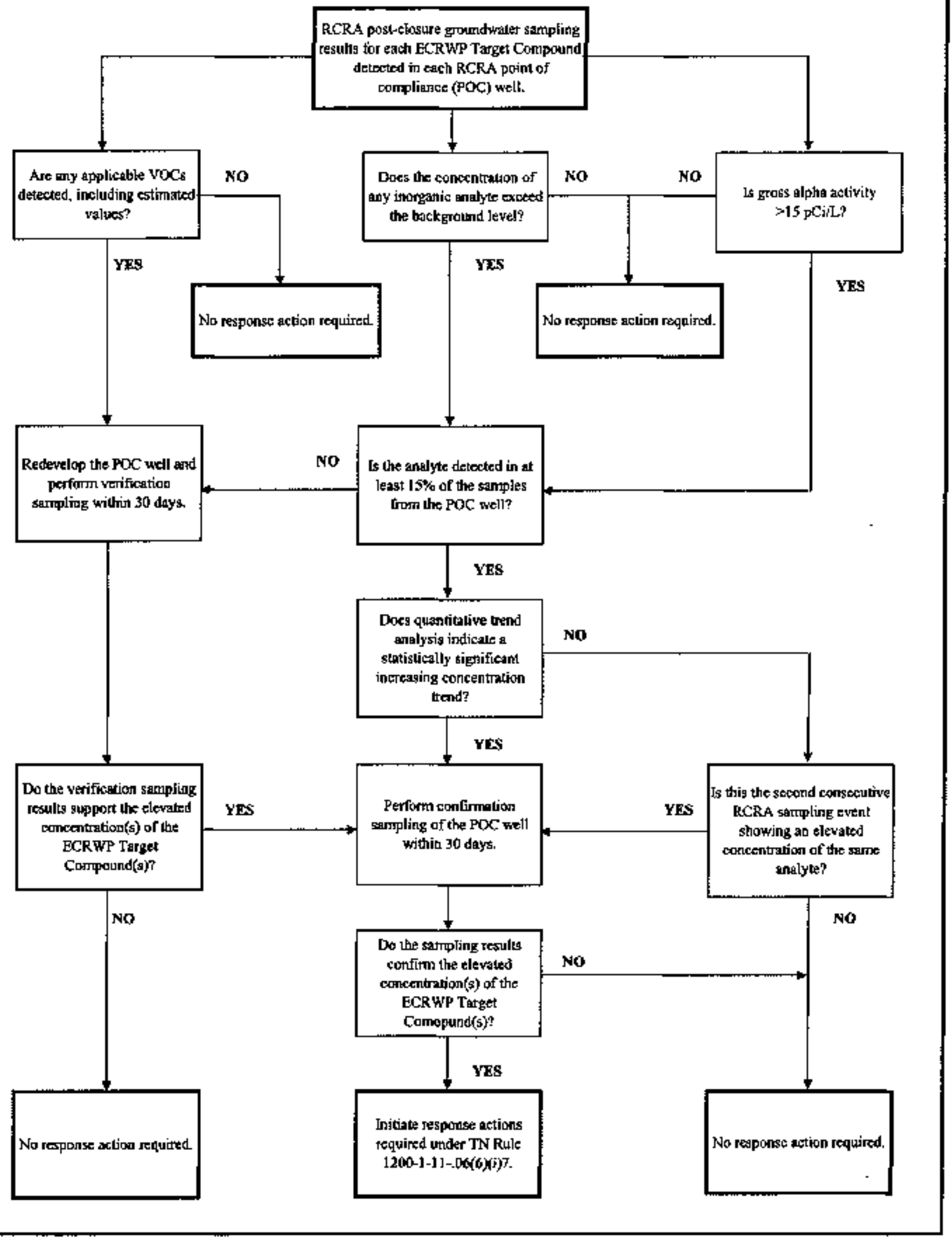

Fig. 1. Techaical appresch for evaluation of and response to groundwater quality dath from RCRA detection mositoring at the East Chestnut Ridge Woste Pile. 


\subsection{Background Comparison}

The PCP requires background values to be recalculated for each inorganic RCRA target list constituent detected in each POC well during each semiannual sampling event at the ECRWP. The background value for each applicable inorganic constituent was determined by the upper tolcrance limit (UTL) calculated from data obtained for a group of upgradient wells since January 1986, including current RCRA post-closure detection monitoring results for upgradient/background well GW-294 (Table 1). Based on comparison with respective background values, elevated concentrations of inorganic RCRA target list constituents wete reported for the groundwater samples collected in January 2007 from POC wells GW-292 (barium, chloride, and nickel) and GW-293 (bariuth and chloride).

The PCP defines a concentration of zero micrograms per liter $(1 \mathrm{~g} / \mathrm{L})$ as the background value for each VOC designated as a RCRA target list constituent for the ECR WP. Excluding false-positive results, none of these VOCs were detected in the groundwater samples collected from the RCRA wells in January 2007.

The PCP sets the background value for gross alpha activity at the 15 picoCuries per liter (pCi/L) maximum contaminant level (MCL) for drinking water. Gross alpha activity reported for the groundwater samples collected from the RCRA wells in January 2007 are all below the background value.

\subsection{Quantitative Trend Analysis}

Under the data evaluation procedure required by the PCP (Fig. 1), quantitative trend analysis (Kendall-Tau or equivalent) is performed for each applicable RCRA target list constituent that has sufficient data; i.e., was detected in least $15 \%$ of the groundwater samples collected from the applicable POC well since January 1991. Based on this criteria, only the elevated concentrations of barium and chloride reported for POC wells GW-292 and GW-293 were evaluated; insufficient data preclude quantitative trend analysis of the elevated nickel concentration reported for POC well GW-292 (see Enclosure 3).

Results of the quantitative trend analysis (Kendall Tau b) indicate statistically significant increasing concentration trends for barium in groundwater at well GW-292 (Fig. 2) and for chloride in greundwater at well GW-293 (Fig. 3). However, regardless of the trends, the elevated barium and chloride concentrations at these wells probably reflect localized geochemical variability and are not indicative of a potential contaminant release from the ECRWP. Extensive historical data from the many twells located on Chestnut Ridge show that barium and chloride are naturally present in the groundwater at concentrations that may exhibit wide local variability. For example, the chloride concentration reported for the groundwater sample collected from upgradient/background well GW-294 in January 2007 (13.5 mg/L) exceeds the background value $(10 \mathrm{mg} / \mathrm{L})$.

Aside from the elevated nickel concentration reported for the groundwater sample collected from well $G W-292$ in January $2007(0.0541 \mathrm{mg} / \mathrm{L})$, nickel was detected in only one previous sample from the well; therefore, insufficient data are avaitable to perform quantitative trend analysis. Elevated nickel concentrations in the groundwater at this well probably do not indicate a contaminant relegse from the ECRWT; trickel is not a prineipal component of the leachate from the site and typically is immobile under the neutral $\mathrm{pH}$ of the groundwater in the well. Based on experience with other wells on Chestnut Ridge, the elevated pickel concentrations may be an artifact of microbiologically-induced corrosion of the stainless steel well screen. 


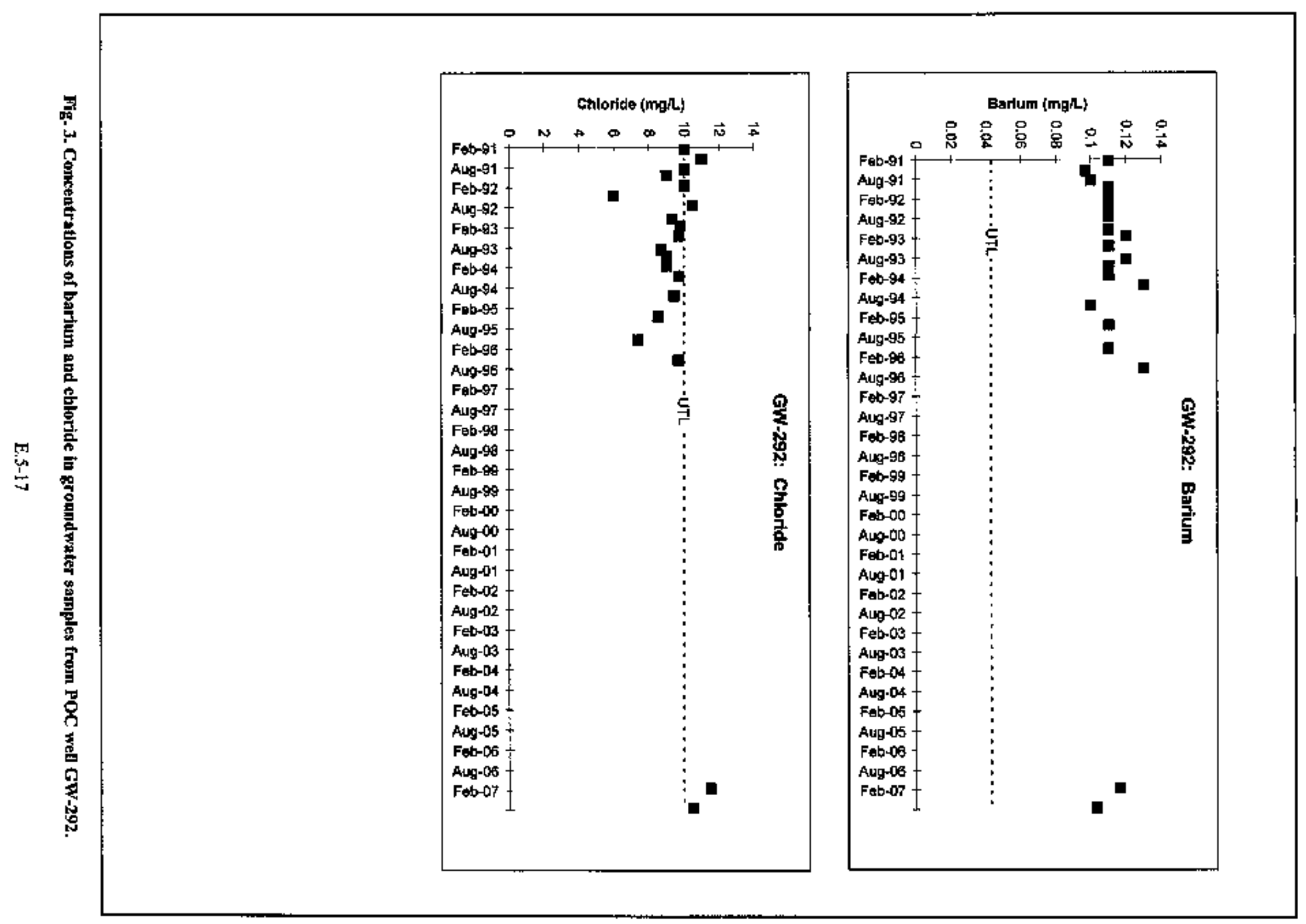



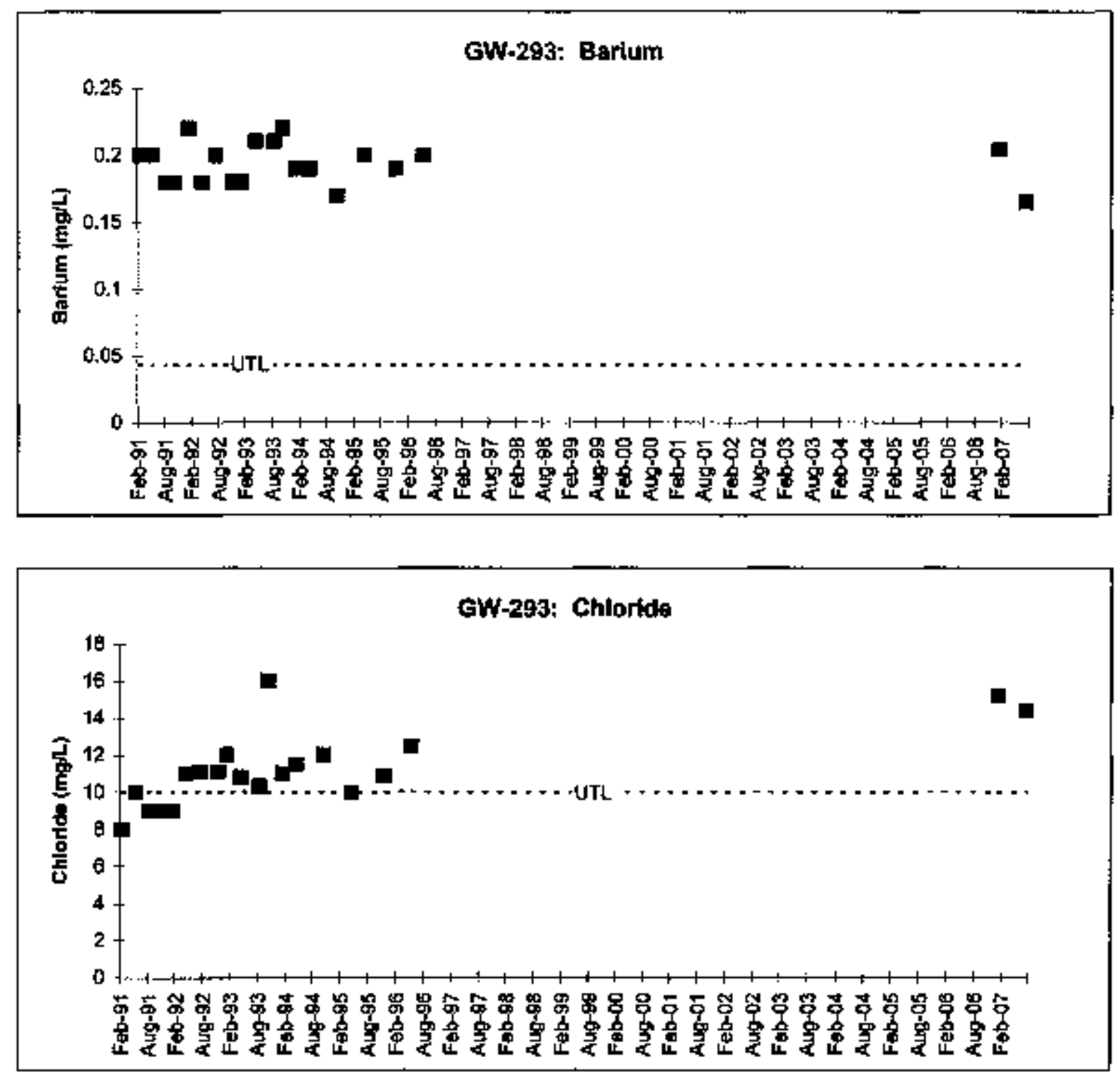

Fig. 3. Concentrations of bariutn and chloride in groubdwater samples from POC wel GW-293. 


\subsection{Elevated Concentration Verification and Conffrmation}

Under the data evaluation procedure defined in the PCP (Fig. 1), verification sampling of tach applicable POC well is required if: (1) an otganic RCRA target list constituent is detected (cxcluding falsc positives), or (2) the concentration of an inorganic or radiological RCRA target list constituent exceeds the corresponding background value, but is detected in less than $15 \%$ of the groundwater samples collected from the well since January 1991. Confirmation sampling is required if: (1) results of verification support the elevated concentration, or (2) the concentration of an inorganic or radiological RCRA target list constituent exceeds the corresponding background value and quantitative trend analysis of the available data indicate a statistically significant increasing trend.

Based on the preceding criteria, the elevated concentrations of RCRA tatget list constituents detected in the groundwater samples collected in January 2007 from POC wells $\mathrm{GW}-292$ and $\mathrm{GW}-293$ warratit verification (nickel at GW-292) or confirmation (barium at GW-292; chloride at GW-293) sampling. However, as discussed in the previous sections, the elevated concentrations of barium, chloride, and nickel are most likely attributable to natural or in-situ geochemical conditions and, as such, do not serve as reliable indicators of potential contaminat releases from the ECKWR. Consequently, sampling to verify/confirm the elevated concentrations was deemed unnecessary.

\subsection{CONCLUSIONS}

A telease or potential release of contaminants to the uppermost aquifer at the ECRWP is not indicted by evaluation of the analytical results reported for the unfiltered groundwater samples collected during January 2007 from the RCRA wells at the site.

The PCP requires semiannual collection of groundwater samples from three POC wells at the ECRWP. Accordingly, wells GW-161, GW-296, and GW-298 will serve as the primary POC wells for future RCRA groundwater sampling events, with wells GW-292 and GW-293 reserved as replacements for any of the primary $\mathrm{POC}$ wells that are irreparably damsged or destroyed. 
This page intentionally left blank.

E.5-20 


\section{SUMMARY OF RCRA POST-CLOSURE DETECTION MONTTORING AT THE EAST CHESTNUT RIDGE WASTE PILE, SECOND SEMIANNUAL REPORTING PERIOD OF CALENDAR YEAR 2007}

\subsection{INTRODUCTION}

This report presents an evaluation of the groundwater quality monitoring data obtained at the East Chestnut Ridge Waste Pile (ECRWP) in July 2007. Groundwater monitoring at the site is required by the Resource Conservation and Recovery Act (RCRA) post-closure permit (PCP) for the Chestnut Ridge Hyatrogeologic Regime, which was issued by the Tennessee Department of Environment and Conservation (TDEC) in September 2006 (TDEC pernit no. TNHW-128).

General and site-specific tems and conditions of the PCP, along with the TDEC hazatdous waste management regulations incorporated by reference, define the site-specific groundwater sampling and analysis requirements for RCRA post-closure detection monitoring at the ECRWP. Implementation of this monitoring program is intended to provide the data needed to detect a release of contaminants to the uppermost aquifer underlying the site.

\subsection{RCRA GROUNDWATER SAMPLING AND ANALYSIS}

Unfiltered groundwater samples were collected in July 2007 from the upgradient/background well (GW-294) and from each of the point-of-compliance (POC) wells (GW-161, GW-292, GW-293, GW-296, and GW-298) that comprise the well network fot RCRA post-clostre detection monitoring at the ECRWP. Grotudwater samples were collected in accordance with the low-flow minimal drawdown sampling procedure referenced in the PCP.

The PCP requires at least three of the POC wells at the ECRWP to be included each semiannual RCRA groundwater sampling event. Nevertheless, all five POC wells were sampled in January and July 2007 in order to determine the condition of each well and obtain recent seasonal monitoring data for these wells, which were last sampled in May 1996.

Groundwater samples collected from the RCRA wells at the ECRWP were analyzed for the sitespecific suite of RCRA target list constituents designated in the PCP (Table 1), which include 21 inorganic analytes (e.g., metals and anions), 14 volatile organic compounds (VOCs), and gross alpha activity. Laboratory analyses of the groundwater samples were performed in accordance with the approved analytical methods referenced in the PCP.

\subsection{DATA EVALUATION}

The PCP recuires the RCRA post-closure detoction monitoring data obtained at the ECRWP to be evaluated in accordance with the procedure flowcharted on Fig. 1. This procedure defines a three-part technical approach whereby: (1) the analytical result for each RCRA target list constituent detected in each POC well is compared to a site-specific background value; (2) if the analytical result exceeds the background value for the RCRA target list constituent, quantitative trend analysis of the data for the constituent is performed (if sufficient data are available) to determine if the elevated concentration reflects a statistically significant increasing temporal trend; and (3) re-sampling of each applicable POC well to verify the efevated (i.e., >background) and increasing concentration trend evident for the applicable RCRA target list constituent(s). 
Table 1. Background values and maximurn concentrations of RCRA target list constituents in POC wells at the ECRWP, July 2007

\begin{tabular}{|c|c|c|c|c|c|c|c|}
\hline \multirow{2}{*}{ Target List Constituent } & \multirow{2}{*}{$\begin{array}{c}\text { Site-Specific } \\
\text { Background } \\
\text { Value }\end{array}$} & \multirow{2}{*}{$\begin{array}{c}\text { July 2007 } \\
\text { Marimum } \\
\text { Concentration }\end{array}$} & \multicolumn{5}{|c|}{$\begin{array}{c}\text { PoC Well(s) With } \\
\text { Elevated Concentration }\end{array}$} \\
\hline & & & GW-16! & GW-292 & GW-293 & GW-296 & GW-298 \\
\hline \multicolumn{8}{|l|}{ Inorganics (mg/L) } \\
\hline Antimony & 0.05 & $0.003 \mathrm{U}$ & . & . & . & . & , \\
\hline Arsenic & 0.05 & $0.005 \mathrm{U}$ & . & & & . & . \\
\hline Barium & 0.043 & 0.165 & . & 0.103 & 0.165 & . & . \\
\hline Boron & 0.12 & $0.01 \mathrm{U}$ & . & . & . & . & , \\
\hline Cadmitm & 0.003 & 0.0002 & . & . & . & . & . \\
\hline Chloride & 10 & 14.4 & . & 10.5 & 14.4 & . & , \\
\hline Chromium & 0,025 & 0.0257 & . & 0.0257 & . & . & . \\
\hline Cobalt & 0.02 & $0.005 \mathrm{U}$ & . & . & . & . & . \\
\hline Copper & 0.027 & 0.0055 & . & . & . & . & . \\
\hline Iron & is & 4.14 & , & . & . & . & . \\
\hline Lead & 0.05 & $0.002 \mathrm{U}$ & . & . & . & . & . \\
\hline Lithium & 0.026 & $0.01 \mathrm{U}$ & . & . & . & . & . \\
\hline Manganese & 0.29 & 0.262 & . & . & . & . & . \\
\hline Mercury & 0.0002 & $0.0002 \mathrm{U}$ & . & $\therefore$ & . & . & . \\
\hline Nickel & 0.05 & 0.0747 & . & 0.0747 & . & . & , \\
\hline Nitrate (as N) & 3 & 0.35 & . & - & , & . & . \\
\hline Selenium & 0.05 & $0.0025 \mathrm{U}$ & . & , & . & . & . \\
\hline Sulfate & 43 & & . & . & . & . & . \\
\hline Thallium & 0.01 & $0.002 \mathrm{U}$ & . & - & . & . & . \\
\hline Uranium & 0.004 & $0.0015 \mathrm{~J}$ & . & . & . & . & . \\
\hline Zinc & 0.12 & $0.01 \mathrm{U}$ & 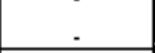 & . & . & 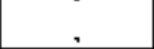 & 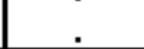 \\
\hline \multicolumn{8}{|l|}{ Organics ( $\mu \mathrm{g} / \mathrm{L}$ ) } \\
\hline Benzene & 0 & $2 \mathrm{U}$ & . & . & . & . & . \\
\hline Carbon Tetrachloride & 0 & $2 \mathrm{U}$ & . & . & . & . & . \\
\hline Chioroform & 0 & $5 \mathrm{U}$ & . & . & . & . & . \\
\hline Cbloromethane & 0 & $10 \mathrm{U}$ & . & . & . & . & . \\
\hline 1,1-Dichloroethane & 0 & $5 \mathrm{U}$ & . & . & . & . & . \\
\hline 1,1-Dichloroethene & 0 & $3 \mathrm{U}$ & . & . & . & . & , \\
\hline 1,2-Dichloroethane & 0 & $2 \mathrm{U}$ & . & + & , & , & . \\
\hline cis-1,2-Dichloroethene & 0 & $5 \mathrm{U}$ & . & . & . & . & . \\
\hline trans-1,2-Dichloroethene & 0 & $5 \mathrm{U}$ & . & . & . & . & . \\
\hline 1,1,1-Trichloroethane & 0 & $2 U$ & . & . & , & . & . \\
\hline Methylene Chloride & 0 & $2 \mathrm{~B}[\mathrm{FP}]$ & . & . & . & , & . \\
\hline Tetrachloroethese & 0 & $2 \mathrm{U}$ & . & . & . & . & . \\
\hline Trichlowocthece & 0 & $2 U$ & . & . & . & . & . \\
\hline Vinyl Chloride & 0 & $1 \mathrm{U}$ & . & . & . & . & . \\
\hline $\begin{array}{l}\text { Radiblogical (pCi/L) } \\
\text { Gross Alpha Activity }\end{array}$ & 15 & 2.18 & . & & . & . & . \\
\hline Notes: $\mathrm{mg} / \mathrm{L}=$ milligram & er, "U" $=$ & detected at & nece & nsho & $\mathrm{j}^{1+}=$ & $\begin{array}{l}\text { ated value } \\
\text { tected); }\end{array}$ & \\
\hline
\end{tabular}




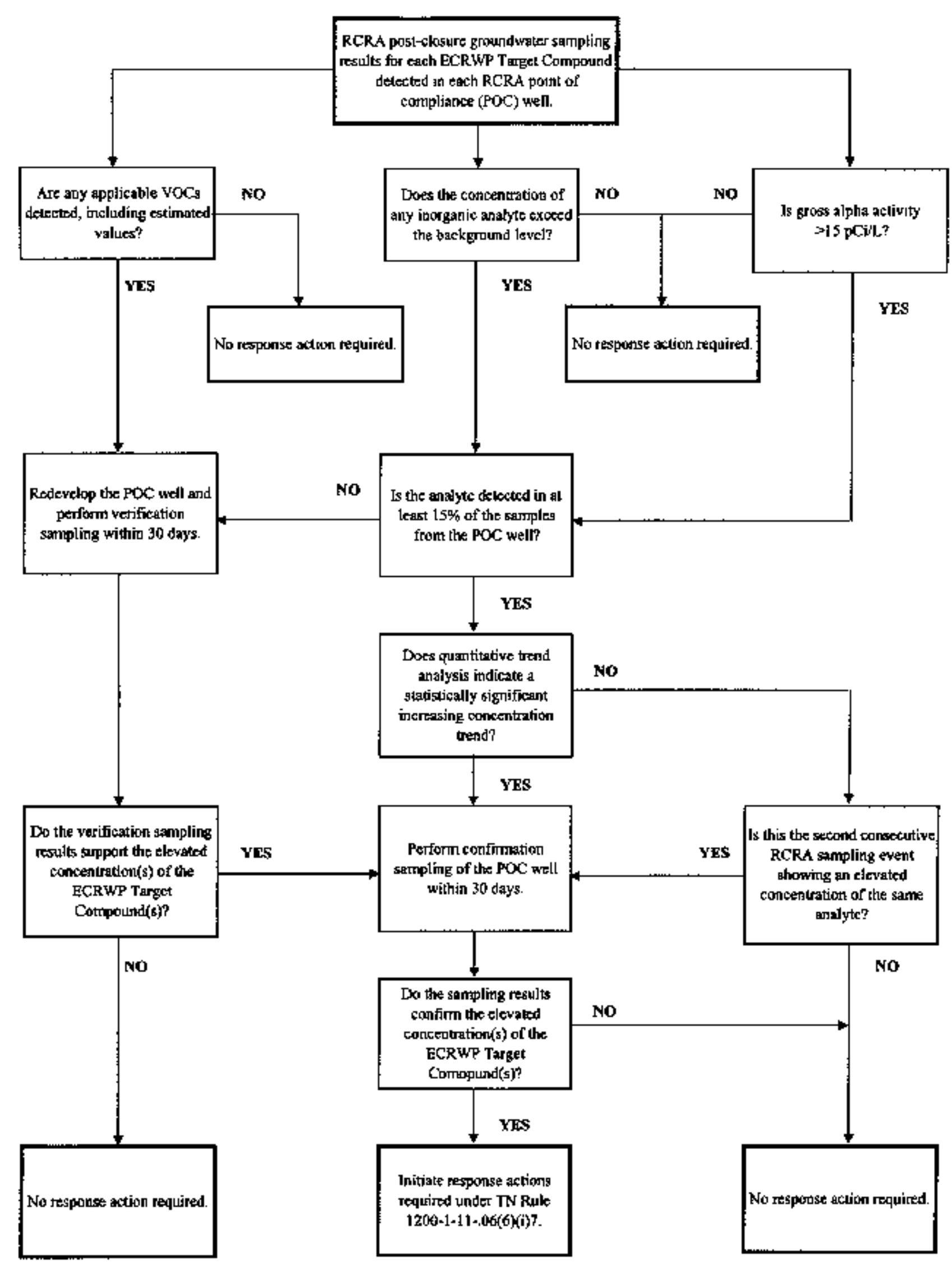

Fig- 1. Technical approach for evaluation of and response to groundwater quality data from RCRA detection monitoring at the East Chestnat Ridge Waste Pìle. 


\subsection{Background Comparison}

The PCP requires background values to be recalculated for each inorganic RCRA target list constitucnt detected in cach POC well during each scmiannual sampling event at the ECRWP. The background valuc for each applicable inorganic constituent was determined by the upper tolerance limit (UTL) calculated using data obtained since January 1986 for a group of wells on Chestnut Ridge, including current RCRA post-closure detection monitoring results for upgradient/background well GW-294 (Table I). Based on comparison to respective background values, elevated concentrations of inorganic RCRA target list constituents were reported for the groundwater samples collected in July 2007 from POC wells GW-292 (barium, chloride, chromium, and nickel) and GW-293 (barium and chloridc).

The PCP defines a concentration of zero micrograms per liter $(\mu \mathrm{g} / \mathrm{L})$ as the background value for each VOC designated as a RCRA target list constituent for the ECRWP. Excluding false-positive results, none of these VOCs were detected in the groundwater samples collected from the RCRA wells in July 2007.

The PCP sets the background value for gross alpha activity at the 15 picoCuries per liter $(\mathrm{pCi} / \mathrm{L}$ ) maximum contaminant level (MCL) for drinking water. Gross alpha activity reported for the groundwater samples collected from the RCRA wells in July 2007 are all below the background value.

\subsection{Quantitative Trend Analysis}

Under the data evaluation ptoceciure requited by the PCP (Fig. 1), quantitative trend analysis (Kendall-Tau ot equivalent) is performed for each applicable RCRA target list constituent that has sufficient data; $t, e_{+}$, was detected in at least $15 \%$ of the groundwater samples collected from the applicable POC well since January 1991. Trend analyses were performed to evaluate the elevated concentrations of barium and chloride reported for POC wells GW-292 and GW-293, but not for the elevated nickel and chromium concentrations reported for well GW-292. Based on previous experience, the elevated nickel and chronium concentrations are likely artifacts attributable to comosion of the stainless steel well casing or screen used to construct the well and are not indicative of a contaminant release from the ECRWP; both metals also were detected in the groundwater sample collected from well GW-292 in January 2007 and personnel with TDEC were notificd.

Results of the quantitative trend analysis (Kendalt Tau b) indicate a statistically significant incteasing concentration trend only for chloride in groundwater at well GW-293. However, regardless of the trends (see Figure 2 and Figure 3), the elevated barium and chloride concentrations at these wells probably reflect localized geochemical variability and are not indicative of a potential contaminant release from the ECRWP. Extensive historical data from many of the wells on Chestnut Ridge show that barium and chloride are naturally present in the groundwater at concentrations that may exhibit wide local variability. For example, the chloride concentration reported for the groundwater samplc collected from upgradient/background well GW-294 in July 2007 (13.5 mg/L) exceeds the background value (10 mg/L). 

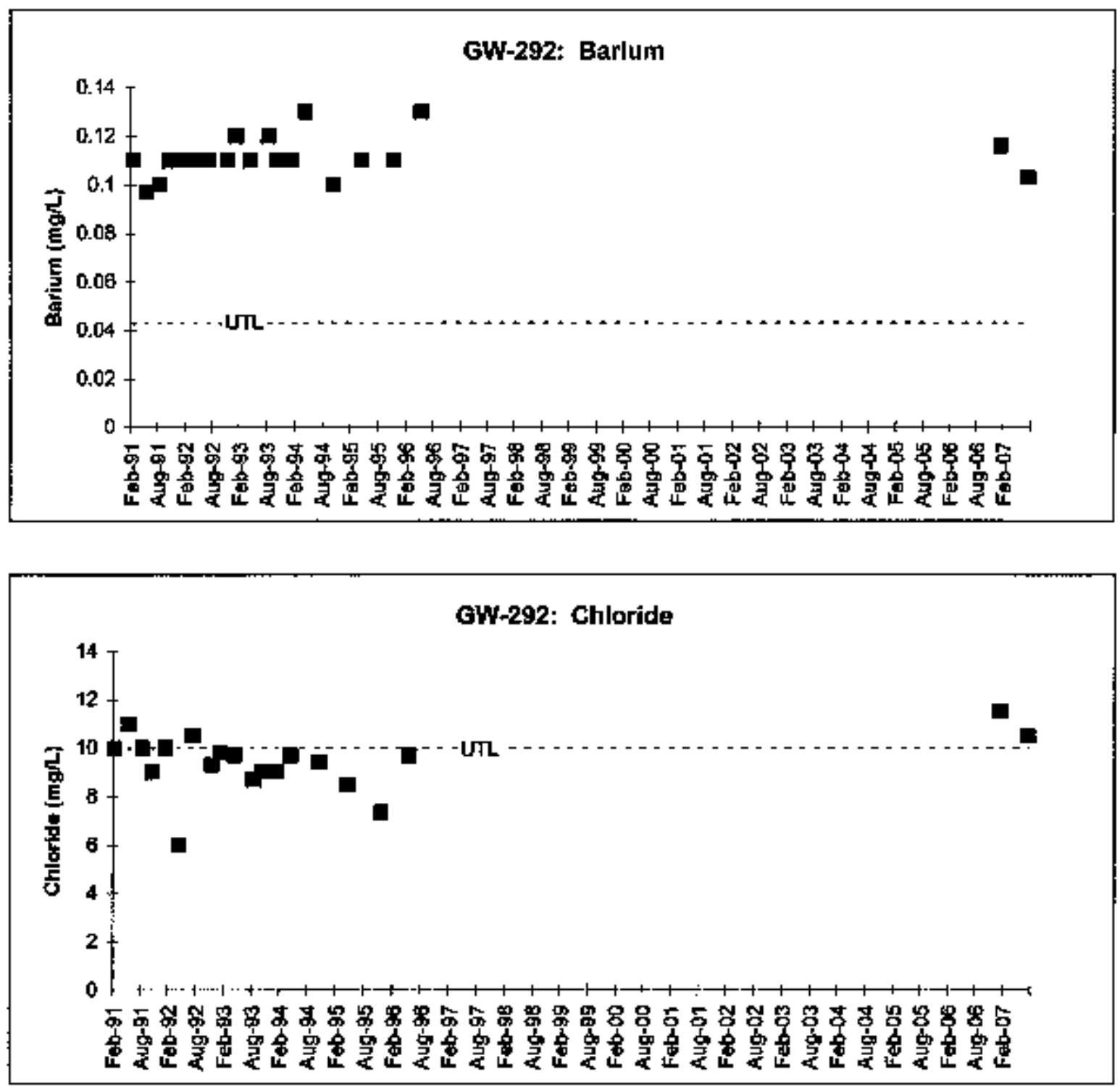

Fitg. 3. Concentrations of barium and chlorkde in groundwater samples from POC well GW-292. 


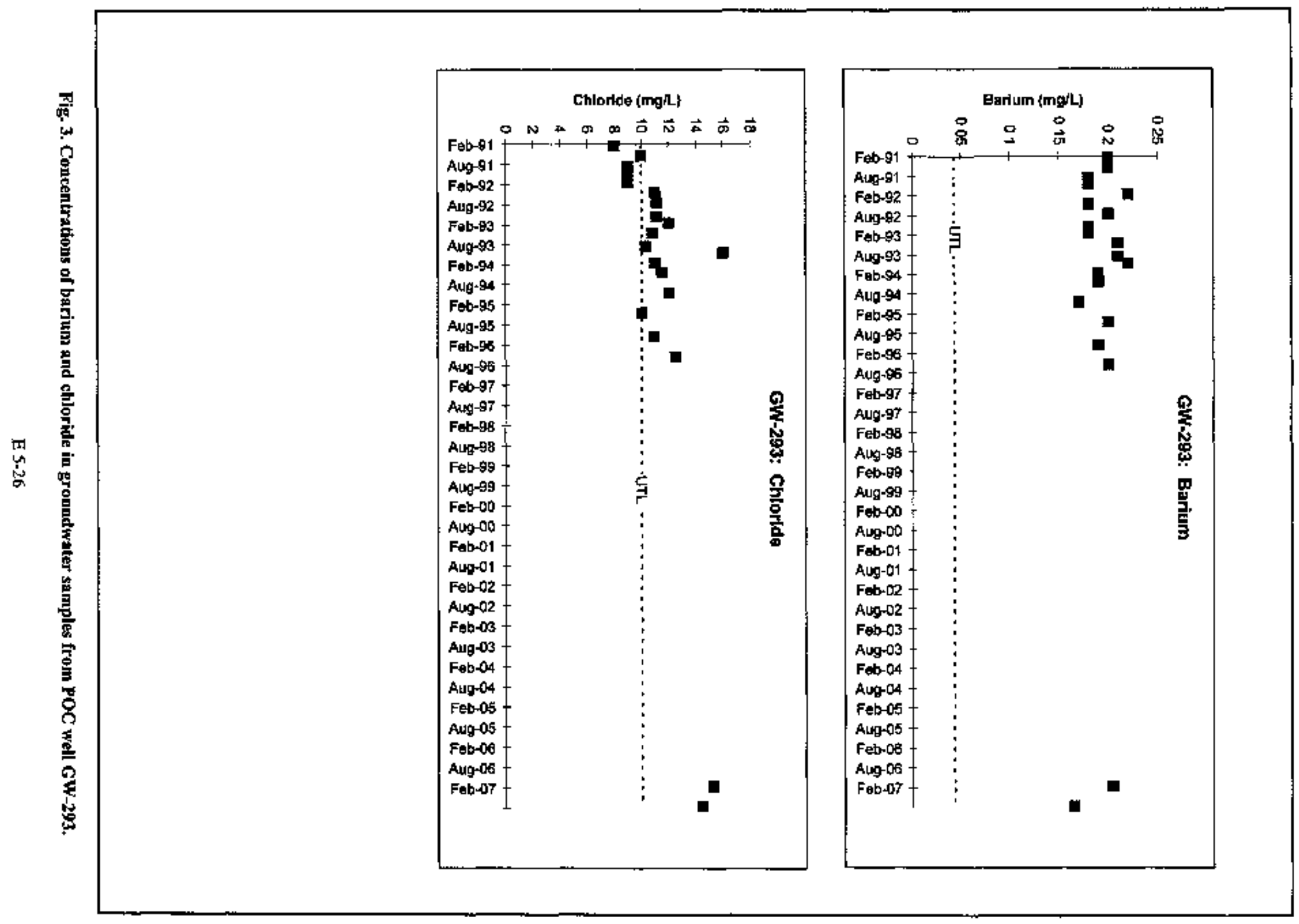




\subsection{Elevated Concentration Verification and Conflumation}

Under the data vvaluation procedure defined in the PCP (Fig. 1), verification sampling of each applicable POC well is required if (1) an organic RCRA target lust constituent is detected (excluding false positives), ot (2) the concentration of an inorganic or radiological RCRA target list constituent exceeds the cortesponding background value, but is detected in less than $15 \%$ of the groundwater samples collected from the well since January 1991. Subsequent confirmation sampling is required if: (1) results of verification sampling support the elevated concentration, or (2) the concentration of an inorganic or radiological RCRA target list constituent exceeds the cotresponding background value and quantitative trend analysis of the available data indicate a statistically significant increasing toend.

Based on the prececting criteria, the elevated concentrations of RCRA target list constituents detected in the groundwater samples collected in July 2007 from POC wells GW-292 and GW-293 warrant verification (chromium and nickel at GW-292) or confirmation (chloride at GW-293) sampling. However, as discussed in the previous sections, the elevated concentrations of barium, chloride, chromium, and nickel are most likely attributable to natural or in-situ geochernical conditions and, as such, do not serve as reliable indicators of potential contaminant releases from the ECRWP. Based on consent from TDEC personnel regarding similar monitoring results for the January sampling ovent, sampling to verify/confirm the elevated concentrations was not performed for the second reporting period of CY 2007.

\subsection{CONCLUSIONS}

Evaluation of the analytical results reported for the unfiltered groundwater samples collected in July 2007 from the RCRA detection monitoring wells at the ECRWP does not indicate a relcase or potential release of contaminants to the uppermost aquifer at the site.

As noted in Sect. 2, the PCP requires semiannual collection of groundwater samples from three POC wells at the ECRWP. Accordingly, wells GW-161, GW-296, and GW-298 will serve as the ptimary POC wells for future RCRA groundwater sampling events, with wells GW-292 and GW-293 reserved as replacements for any of the primary POC wells that become irreparably damaged or destroyed. 
BJC/OR-2988

\section{RECORD COPY DISTRIBUTION}

File-EMEF DMC-RC 